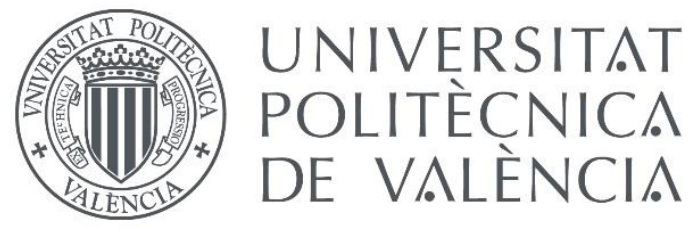

\title{
Self-healing concrete: efficiency evaluation and enhancement with crystalline admixtures
}

\author{
DOCTORAL THESIS \\ Author: Marta Roig Flores \\ Supervisor: Prof. Pedro Serna Ros \\ Valencia, Spain \\ February 2018 \\ UNIVERSITAT POLITÈCNICA DE VALÈNCIA \\ PROGRAMA DE DOCTORADO EN INGENIERÍA DE LA CONSTRUCCIÓN
}





\title{
Self-healing concrete: efficiency evaluation and enhancement with crystalline admixtures
}

\author{
by \\ Marta Roig Flores \\ THESIS \\ Submitted in fulfillment of the requirements for the degree of Doctor of Philosophy in \\ Building Engineering from the Departamento de Ingeniería de la Construcción y de \\ Proyectos de Ingeniería Civil of the Universitat Politècnica de València \\ Supervisor: Prof. Pedro Serna Ros

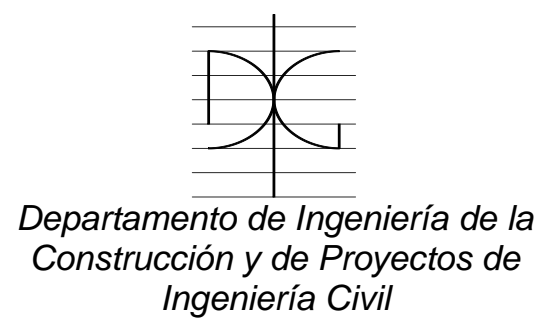

\section{느ICITECH Hormigón} \\ Instituto de Ciencia y Tecnología del
}

\section{External evaluation committee:}

Prof. Jean-Philippe Charron, Polytechnique Montréal Prof. Pedro Garcés Terradillos, Universidad de Alicante Dr. Christof Schröfl, Technische Universität Dresden

\section{Thesis committee:}

Prof. Amparo Moragues Terrades, Universidad Politécnica de Madrid Prof. Ana Ma Guerrero Bustos, Inst. Eduardo Torroja de Ciencias de la Construcción Prof. Jean-Philippe Charron, Polytechnique Montréal

\author{
UNIVERSITAT POLITÈCNICA DE VALÈNCIA \\ Valencia, Spain \\ February 2018
}



To Sonia and Gonçal 



\section{Abstract}

Self-healing materials are materials with the capability to repair their damage autogenously or with minimal help from an external stimulus. In the construction field, the development of self-healing elements will increase the durability of structures and reduce their maintenance and repair actions.

Reinforced concrete elements frequently suffer small cracks $(<0.3 \mathrm{~mm})$ due to the low tensile strength of concrete. These cracks are not relevant from the mechanical point of view, but they can be an entrance point for aggressive agents that could initiate degradation processes in the element. Concrete has a natural self-healing capability able to seal small cracks, named autogenous healing, that is mainly produced by the continuing hydration and carbonation processes. However, this self-healing capability is limited and therefore it is typically disregarded in the design of concrete structures.

Recent studies have attempted to surpass the limitations of autogenous healing in two ways: developing concrete compositions to improve autogenous healing, or designing specific products to achieve self-healing, also known as autonomous self-healing. The latter selfhealing products include, among others: crystalline admixtures, micro- or macroencapsulated agents, and even the use of calcium carbonate-precipitating bacteria. All these products are in different stages of maturity, and some of them are still in development.

Crystalline admixtures (CA) are a type of permeability reducing admixture that is claimed to provide self-healing properties. However, the lack of knowledge on their behavior and self-healing properties limits their usage. In addition, the methods to evaluate the selfhealing capability of mortar and concrete are not standardized yet. This complicates the assessment of the self-healing response, and increases the complexity of a critical analysis of the different self-healing products and evaluation methods found in the literature.

In order to answer to the lack of knowledge and uncertainties discussed above, the main objectives of this $\mathrm{PhD}$ thesis are: 1) to study and propose experimental procedures in order to efficiently evaluate self-healing phenomena and, 2) to evaluate experimentally the selfhealing enhancements produced when introducing crystalline admixtures in concrete.

This thesis includes the following tests for the determination of the self-healing properties: the evaluation of crack closing using different parameters, water permeability of cracked concrete specimens using high water pressure, three point bending tests to analyze expressions for quantifying the mechanical recoveries and, considerations when using capillary absorption test. In this work, several experimental campaigns in mortar and concrete have been performed with the objective of validating the proposed tests. Afterwards, these methods have been used to analyze the influence of several parameters on self-healing. The analyzed parameters include among others: the presence of crystalline admixtures, the damage extent (single cracks from 0.1 to $0.4 \mathrm{~mm}$ ), healing time needed, concrete composition and influence of the healing conditions. Finally, the effects that crystalline admixtures produce in concrete are analyzed in terms of slump, strength and hydration. 
The results show that crack closing is an effective and simple method to evaluate selfhealing. However, the orientation of the crack during healing is of great importance, and disregarding this aspect may lead to misleading conclusions. The water permeability method proposed in this work has good stability and it is easy to implement in concrete laboratories. Moreover, the relations obtained between crack parameters and water permeability confirmed the cubic relation, as reported in the literature, with some dispersion produced by the in-depth geometry of the cracks and the presence of fibers. This work shows that analyzing healing efficiency by means of crack closing tends to overestimate self-healing if compared with the results obtained by means of water permeability. Sorptivity analysis tests were easy to implement, however, the results obtained in this work showed high dispersion and sensitivity to the variations of the cracks introduced during the precracking process.

Regarding the evaluation of mechanical recoveries, the results show that the evolution of concrete properties with time is a parameter of importance that, therefore, should be considered, especially for early age cracks and self-healing products with small ranges of expected values. The results obtained for strength recovery in this work did not align with the results reported in the literature: no peak recoveries have been detected after two months of healing, and very similar stiffness values were obtained for specimens healed in water immersion or in humidity chamber.

As in the case of autogenous healing, CA were not able to heal cracks at high levels of relative humidity. Complete water immersion led to the best results out of all the experimental methodologies used in this thesis. For both types of healing, continuous water immersion and wet/dry cycles are able to achieve good crack closing and permeability results, showing almost complete healing in 2 months of healing time for early age cracks up to $0.30 \mathrm{~mm}$. Most of the recoveries took place during the first 14 days of healing. Older cracks showed significant but reduced healing capabilities.

The healing results obtained when using CA are not drastically different from autogenous healing. The main benefit of using CA has been found to be a more stable behavior than autogenous healing as measured with the water permeability tests, with higher minimum healing results. However, no clear benefits were found for crack closing or mechanical recoveries. CA increased workability and strength in concrete and mortar specimens; however, they also increased the setting time in mortar mixes, which was verified with isothermal calorimetry. The chemical analyses performed showed potentially different products labelled under the name of crystalline admixtures. Furthermore, the composition of the byproducts produced by the self-healing reaction with CA were the same as those produced by autogenous healing: calcite, brucite and aragonite.

In this work, crystalline admixtures have been reported as an enhancer of self-healing reactions, but with a limited capacity of enhancement. The proximity of CA to the industry is a positive point to their inclusion as a new type of admixture for concrete. However, the results obtained in this thesis indicate further analyses are needed to determine their full effects on concrete, especially regarding self-healing. 


\section{Resum}

Els materials autosanables són materials amb la capacitat de reparar els seus danys de forma autònoma o amb ajuda mínima d'estímuls externs. En el camp de la construcció, el desenvolupament d'elements autosanables augmentarà la durabilitat de les estructures i reduirà les accions de manteniment i reparació.

Els elements de formigó armat presenten freqüentment fissures menudes $(<0.3 \mathrm{~mm})$ degut a la baixa resistència a tracció del formigó. Aquestes fissures no són rellevants des del punt de vista mecànic, però poden suposar un punt d'entrada per a agents agressius que podrien iniciar processos de degradació en l'element. El formigó té una capacitat de autosanació natural capaç de tancar fissures menudes, anomenada sanació autògena, produïda principalment per la hidratació continuada i la carbonatació. En canvi, aquesta capacitat és limitada i per tant és descartada en el disseny de estructures de formigó.

Estudis recents han intentat sobrepassar les limitacions de la sanació autògena per dues vies: desenvolupant composicions de formigó per millorar la sanació autògena, o dissenyant productes específics per aconseguir autosanació, en aquest cas anomenada sanació autònoma. Aquests productes per a aconseguir autosanació inclouen, entre d'altres, additius cristal-lins, agents micro- o macroencapsulats, i fins i tot l'ús de bacteris que produeixen carbonat càlcic. Tots aquests productes es troben en diferents etapes de maduresa, i algunes d'elles encara estan en desenvolupament.

Els additius cristal-lins (CA) són un tipus d'additiu reductor de la permeabilitat que es considera que proporciona propietats de autosanació. No obstant, la manca de coneixement sobre el seu comportament i sobre les propietats de autosanació que aporta limita el seu ús. A més, els mètodes per avaluar la capacitat d'autosanació de formigons encara no estan estandarditzats. Açò complica la seua avaluació i augmenta la complexitat per fer una anàlisi crítica dels diferents productes i mètodes d'avaluació de la literatura.

Per respondre a aquesta manca de coneixement $\mathrm{i}$ incertesa, els principals objectius d'aquesta tesi doctoral són: 1) estudiar i proposar procediments experimentals per avaluar de manera eficient els fenòmens d'autosanació i, 2) avaluar experimentalment les millores en autosanació produïdes en introduir additius cristal·lins al formigó.

Aquesta tesi inclou com assajos per a la determinació de l'autosanació: l'avaluació del tancament de fissures usant diferents paràmetres, la permeabilitat a l'aigua de formigó fissurat utilitzant aigua a alta pressió, assajos de flexió a tres punts per analitzar expressions que quantifiquin les recuperacions mecàniques, i consideracions respecte a l'assaig d'absorció capil·lar. En aquest treball s'han realitzat diverses campanyes experimentals, tant en morter com a formigó, amb l'objectiu de validar els assajos proposats. Posteriorment, aquests assajos s'han utilitzat per analitzar la influència de diversos paràmetres en l'autosanació. Els paràmetres estudiats inclouen entre d'altres: presència d'additius cristal-lins, nivell de dany (fissura entre 0.1 i $0.4 \mathrm{~mm}$ ), temps necessari per a la sanació, composició del formigó i influència de condicions de sanació. Finalment, s'analitzen els efectes produïts en afegir additius cristal-lins en formigó en fluïdesa, resistència i hidratació. 
Els resultats mostren que el tancament de fissures és un assaig eficaç i senzill per avaluar l'autosanació. No obstant això, l'orientació de la fissura durant la sanació ha resultat ser de gran importància, i descartar aquest aspecte pot portar a conclusions enganyoses. L'assaig de permeabilitat a l'aigua proposat presenta una bona estabilitat i és fàcil d'implementar en laboratoris de formigó. A més, les relacions obtingudes entre els paràmetres de fissura i la permeabilitat a l'aigua han confirmat la relació cúbica de la literatura, amb certa dispersió produïda per la geometria interna de les fissures i la presència de fibres. Aquest treball mostra que analitzar l'eficiència de l'autosanació amb el tancament de fissures pot sobreestimar la capacitat de sanació, comparada amb els resultats obtinguts-dues mitjançant permeabilitat a l'aigua. Els assajos de sorptivitat van resultar fàcils d'implementar, però, els resultats obtinguts en aquest treball van mostrar una alta dispersió i sensibilitat a les variacions en les fissures produïdes durant el procés de prefissuració.

Pel que fa a l'avaluació de la recuperació mecànica, els resultats mostren que l'evolució de les propietats del formigó amb el temps és un paràmetre d'importància que, per tant, s'ha de considerar, especialment per fissures primerenques, i per a productes d'autosanació amb valors esperats de poc rang. Els resultats obtinguts de recuperacions mecàniques en aquest treball no coincideixen amb els de la literatura: no s'han detectat noves càrregues pics després de dos mesos de sanació, i els valors de rigidesa després del procés de sanació han resultat molt similars per a provetes en immersió d'aigua i càmera d'humitat.

Així com en la sanació autògena, els CA no van ser capaços de sanar fissures a alta humitat relativa. La immersió completa en aigua condueix als millors resultats en totes les metodologies experimentals utilitzades en aquesta tesi. Per als dos tipus de sanació, la immersió contínua en aigua i els cicles d'immersió/assecat poden aconseguir resultats bons de tancament de fissures i permeabilitat, mostrant un sanat gairebé complet després de 2 mesos, per a fissures primerenques fins $0.30 \mathrm{~mm}$. La major part de les recuperacions ocorregueren els primers 14 dies. Fissures de major edat mostraren capacitat de sanació però reduïda.

Els resultats obtinguts utilitzant $\mathrm{CA}$ no són dràsticament diferents respecte a la sanació autògena. El benefici d'utilitzar CA s'ha trobat en un comportament més estable, mitjançant els assajos de permeabilitat, que obtingueren valors mínims més alts. No obstant això, no es trobaren millores en tancament de fissures ni en recuperacions mecàniques. Aquests additius van incrementar la treballabilitat i resistència en formigó i morter; però, també va augmentar el temps d'enduriment en morter, verificat mitjançant calorimetria isotèrmica. Les anàlisis químiques realitzades van mostrar productes potencialment diferents etiquetats sota el nom d'additius cristal-lins. A més, la composició dels precipitats formats per la reacció d'autosanació amb CA resultaren els mateixos que els produïts per la sanació autògena: calcita, brucita $\mathrm{i}$ aragonita.

En aquest treball s'ha obtingut que els additius cristal-lins potencien les reaccions d'autosanació, però tenen una capacitat limitada. La proximitat dels CA a la indústria és un punt positiu per a la seva inclusió com un nou tipus d'additiu de formigó. Tanmateix, els resultats obtinguts en aquesta tesi indiquen que calen més anàlisis per determinar els seus efectes complets en formigó, especialment pel que fa a l'autosanació. 


\section{Resumen}

Los materiales autosanables son materiales con la capacidad de reparar sus daños de forma autónoma o con ayuda mínima de estímulos externos. En el campo de la construcción, el desarrollo de elementos autosanables aumentará la durabilidad de las estructuras y reducirá las acciones de mantenimiento y reparación.

Los elementos de hormigón armado presentan frecuentemente pequeñas fisuras $(<0.3 \mathrm{~mm})$ debido a la baja resistencia a tracción del hormigón. Estas fisuras no son relevantes mecánicamente, pero pueden suponer un punto de entrada para agentes agresivos que podrían iniciar procesos de degradación en el elemento. El hormigón tiene una capacidad de autosanación natural capaz de cerrar pequeñas fisuras, denominada sanación autógena, producida principalmente por la hidratación continuada y la carbonatación. Sin embargo, esta capacidad es baja, y por tanto es descartada en el diseño de estructuras de hormigón.

Estudios recientes han intentado sobrepasar los límites de la sanación autógena mediante dos caminos: desarrollando composiciones de hormigón para mejorar la sanación autógena, o diseñando productos específicos para conseguir autosanación, en este caso llamada sanación autónoma. Estos productos para conseguir autosanación incluyen, entre otros, aditivos cristalinos, agentes micro o macroencapsulados, e incluso el uso de bacterias que producen carbonato cálcico. Todos estos productos se encuentran en diferentes etapas de madurez, y algunas de ellas aún están en desarrollo.

Los aditivos cristalinos (CA) son un tipo de aditivo reductor de la permeabilidad que se considera que aporta propiedades de autosanación. No obstante, la falta de conocimiento sobre su comportamiento y sobre las propiedades de autosanación que aporta limita su uso. Además, los métodos para evaluar la autosanación en hormigones no están estandarizados todavía. Esto complica su evaluación y aumenta la complejidad para realizar un análisis crítico de los diferentes productos y métodos de evaluación de la literatura.

Para responder a esta falta de conocimiento e incertidumbre, los principales objetivos de esta tesis doctoral son: 1) estudiar y proponer procedimientos experimentales para evaluar de manera eficiente los fenómenos de autosanación y, 2) evaluar experimentalmente las mejoras en autosanación producidas al introducir aditivos cristalinos en el hormigón.

Esta tesis incluye como ensayos para la determinación de la autosanación: la evaluación del cierre de fisuras usando diferentes parámetros, la permeabilidad al agua de hormigón fisurado con agua a alta presión, ensayos de flexión a tres puntos para analizar expresiones que cuantifiquen las recuperaciones mecánicas, y consideraciones respecto al ensayo de absorción capilar. En este trabajo se han realizado varias campañas experimentales, tanto en mortero como en hormigón, para validar los ensayos propuestos. Posteriormente, estos ensayos se han utilizado para analizar la influencia de varios parámetros en la autosanación. Los parámetros estudiados incluyen entre otros: presencia de aditivos cristalinos, nivel de daño (fisura entre 0.1-0.4 mm), tiempo necesario para el sanado, composición del hormigón e influencia de condiciones de sanado. Finalmente, se analizan los efectos producidos al añadir aditivos cristalinos en hormigón en la fluidez, resistencia e hidratación. 
Los resultados muestran que el cierre de fisuras es un ensayo eficaz y sencillo para evaluar la autosanación. Sin embargo, la orientación de la fisura durante el sanado ha resultado ser de gran importancia, y no considerar este aspecto puede llevar a conclusiones engañosas. El ensayo de permeabilidad al agua propuesto en este trabajo presenta una buena estabilidad y es fácil de implementar en laboratorios de hormigón. Además, las relaciones obtenidas entre los parámetros de fisura y la permeabilidad del agua han confirmado la relación cúbica indicada en la literatura, con cierta dispersión producida por la geometría interior de las fisuras y la presencia de fibras. Este trabajo muestra que analizar la eficiencia de autosanado mediante el cierre de fisuras puede llevar a una sobreestimación de la capacidad de sanación, comparada con los resultados obtenidos mediante permeabilidad al agua. Los ensayos de sorptividad resultaron fáciles de implementar, sin embargo, los resultados obtenidos en este trabajo mostraron una alta dispersión y sensibilidad a las variaciones en las fisuras producidas durante el proceso de prefisuración.

En cuanto a la evaluación de la recuperación mecánica, los resultados muestran que la evolución de las propiedades del hormigón con el tiempo es un parámetro importante que, por tanto, debe considerarse, especialmente en fisuras de edades tempranas y en productos de autosanación con valores esperados de rango pequeño. Los resultados obtenidos en cuanto a recuperación de resistencia no coinciden con la literatura: no se han detectado nuevas cargas picos tras dos meses de sanado y los valores de rigidez después del sanado han resultado ser muy similares para probetas en inmersión en agua y en cámara húmeda.

Al igual que en la sanación autógena, los CA no fueron capaces de sanar fisuras a alta humedad relativa. La inmersión completa en agua condujo a los mejores resultados en todas las metodologías utilizadas en esta tesis. Para los dos tipos de sanación, la inmersión continua en agua y los ciclos inmersión/secado pueden lograr buenos resultados de cierre de fisuras y permeabilidad, mostrando un sanado casi completo tras 2 meses, para fisuras temprana hasta $0.30 \mathrm{~mm}$. La mayor parte de las recuperaciones tuvieron lugar en los primeros 14 días. Fisuras de mayor edad mostraron capacidad de sanado pero reducida.

Los resultados obtenidos al utilizar CA no son drásticamente diferentes respecto a la sanación autógena. El beneficio de utilizar CA se ha encontrado en un comportamiento más estable, mediante los ensayos de permeabilidad, obteniendo resultados de sanado mínimo más alto. Sin embargo, no se encontraron mejoras de cierre de fisuras ni de recuperaciones mecánicas. Estos aditivos incrementaron la trabajabilidad y resistencia en hormigón y mortero; sin embargo, también aumentaron el tiempo de fraguado en mortero, verificado mediante calorimetría isotérmica. Los análisis químicos realizados mostraron productos potencialmente diferentes etiquetados bajo el nombre de aditivos cristalinos. Además, la composición de los precipitados formados por la reacción de sanación con CA resultaron los mismos que los producidos por la sanación autógena: calcita, brucita y aragonita.

En este trabajo se ha obtenido que los aditivos cristalinos potencian las reacciones de autosanación, pero tienen una capacidad limitada. La proximidad de los CA a la industria es un punto positivo para su inclusión como un nuevo tipo de aditivo de hormigón. Sin embargo, los resultados obtenidos en esta tesis indican que se necesitan más análisis para determinar sus efectos completos en hormigón, especialmente con respecto a la autosanación. 


\section{Acknowledgements}

First, I would like to thank my supervisor, Professor Pedro Serna for his trust and guidance during these years. Thank you for giving me this opportunity and introducing me into research, for all the invaluable experiences and knowledge, which have made me grow both personally and professionally. Thank you for always pushing me to move forward.

This thesis would not have been possible without the work of the students that were part of the self-healing team that worked at the Instituto de Ciencia y Tecnología del Hormigón (ICITECH, UPV): Simone Moscato, Francesco Pirritano and Laura Rubio. I would also like to thank Prof. Liberato Ferrara from Politecnico di Milano for the collaboration and the fruitful discussions during these years. I would also like to acknowledge Mercedes Sánchez from Instituto Eduardo Torroja de Ciencias de la Construcción for the XRD analyses of the crystalline admixtures.

This work would not have been possible without the financial support provided by Sika A.G. Thanks also to Sika Spain, Elite Cementos and Lafarge for the supply of the different materials.

Thanks to the technicians Paco and Jürgen, for their support in the laboratory but also for all the laughs and our conversations on politics and music.

During these years I have shared experiences and laboratory and office work with many people at ICITECH, from which I would like to give special mention to Itziar and Mabel for their sincere support. Thanks to the professors of the research group, especially to Guillermo for the honest comments and the history-politics lessons during coffee breaks.

I would like to express my gratitude to Prof. Abir Al-Tabbaa for allowing me to stay at the Department of Engineering of the University of Cambridge, and to Dr. Chrysoula Litina, my mentor during the stay, for her valuable comments. Thanks to the GRO group for their kind welcome, and to Carlos and Arnau for making me feel at home during the stay. I would like to acknowledge the COST Action Sarcos and the Erasmus+ Programme for the grants that made this stay possible.

Thanks to my friends who always had words of encouragement: Martí, Marilyn, Laura, Eloy, Cristina, Borja, Antonio, Carlos and Eva, from Civil Engineering, and to all the colleagues of the MSc in Concrete Engineering. Thank you to my new colleagues at the Instituto Eduardo Torroja de Ciencias de la Construcción too, for the all the support during these last months: Mercedes G, Javi L, Javier P, Kristina and Tamara, and to $\mathrm{M}^{\mathrm{a}}$ Cruz Alonso for her continuous support and understanding.

Special thanks to my family for their love and support, especially to my sister, Sonia. Last but not least, now it is my turn to give you a special "thank you", Gonçal: thanks for your love, your infinite patience and for all the advices regarding English and scientific writing (aka. SVO). 



\section{Index}

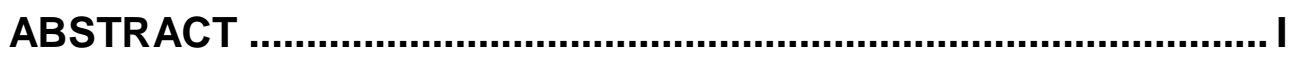

RESUM ........................................................................................ III

RESUMEN ..................................................................................... V

ACKNOWLEDGEMENTS ........................................................... VII

INDEX

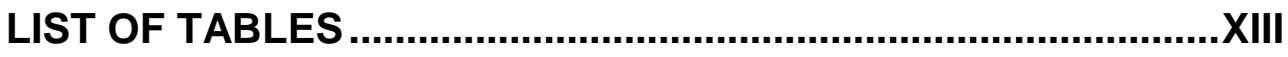

LIST OF FIGURES ................................................................. XV

LIST OF ABBREVIATIONS AND NOTATION .............................. XXII

CHAPTER 1. INTRODUCTION.................................................... 1

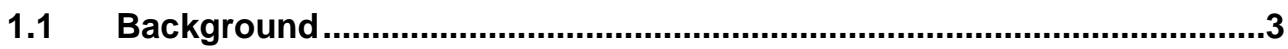

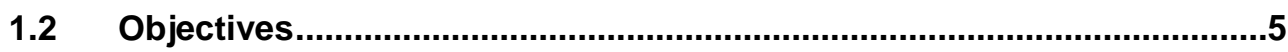

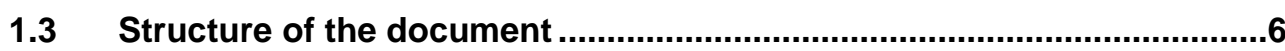

CHAPTER 2. AN OVERVIEW OF SELF-HEALING CONCRETE .. 9

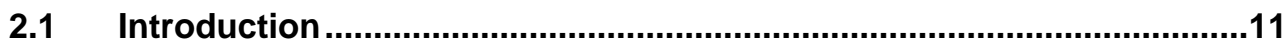

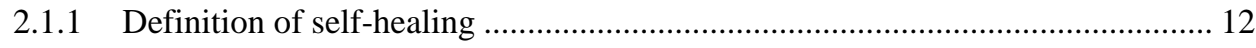

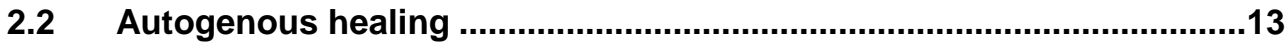

2.2.1 Continuing hydration effect on autogenous healing ....................................... 14

2.2.2 Carbonation effect on autogenous healing .................................................... 15

2.2.3 Other chemical processes that may influence autogenous healing ................... 16 


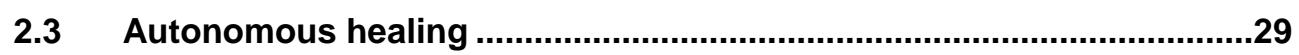

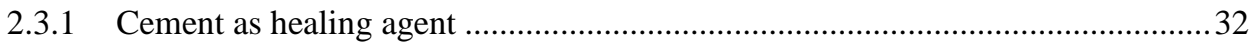

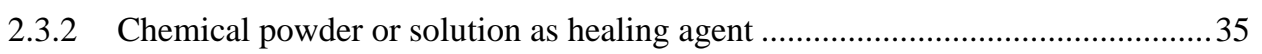

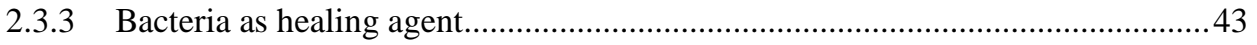

2.4 Experimental tests to evaluate self-healing in concrete........................46

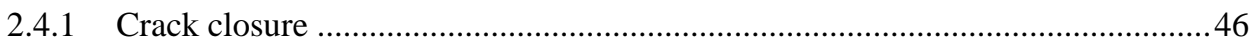

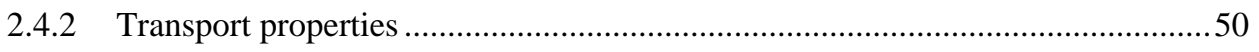

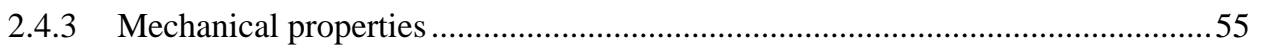

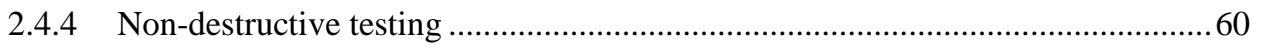

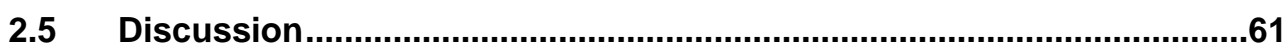

CHAPTER 3. SELECTION AND DEVELOPMENT OF THE

EXPERIMENTAL METHODS ..........................................................67

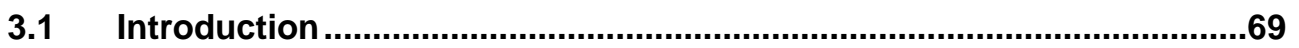

3.1.1 Developments derived from this thesis ........................................................69

3.1.2 General considerations for the experimental work ........................................... 70

3.1.3 Base concrete mixture proportions .......................................................... 71

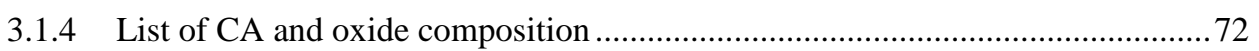

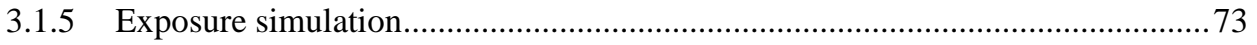

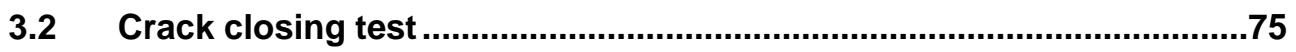

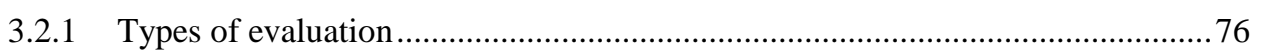

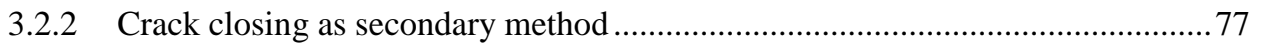

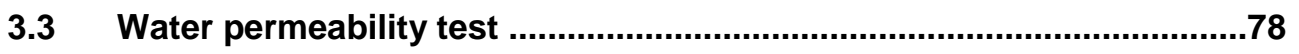

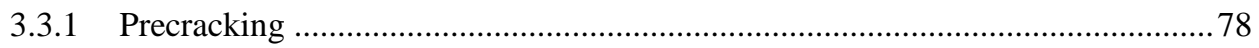

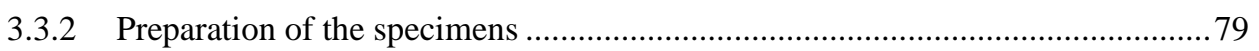

3.3.3 Water permeability test on cracked concrete ............................................... 79

3.4 Mechanical properties ...................................................................81

3.4.1 Healed specimens compared with themselves before healing ........................... 85

3.4.2 Healed specimens compared with accompanying specimens .............................. 88

$\mathrm{X}$ 


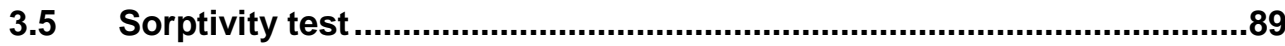

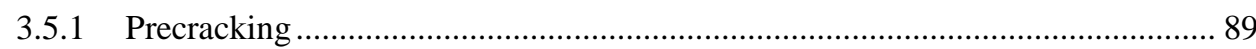

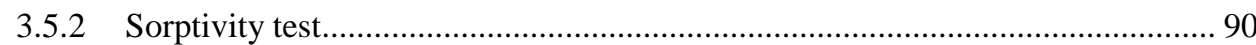

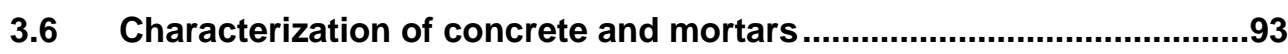

3.6.1 Workability and compressive strength of concrete ....................................... 93

3.6.2 Workability and compressive strength of mortars............................................ 95

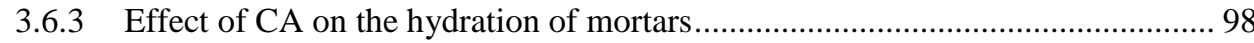

\section{CHAPTER 4. VALIDATION OF THE METHODOLOGIES FOR} THE EVALUATION OF SELF-HEALING...................................... 105

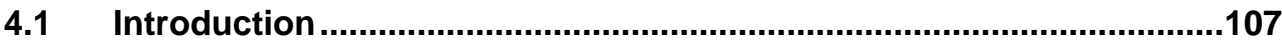

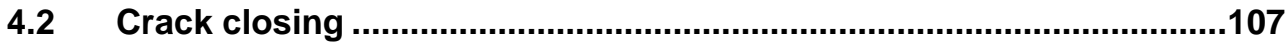

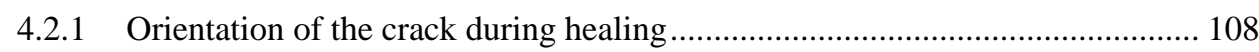

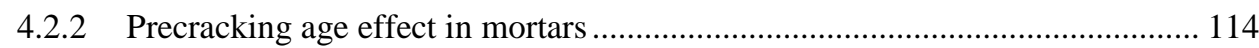

4.2.3 Estimation of the healing speed and healable crack width in concrete ............. 115

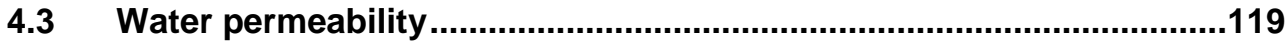

4.3.1 Repeatability of the water permeability test proposed .................................... 120

4.3.2 Effect of intermediate water permeability tests in concrete ........................... 122

4.3.3 Precracking age effect in concrete............................................................... 124

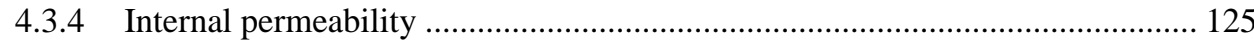

4.4 Relation between crack closing and permeability tests ......................128

4.5 Mechanical properties .....................................................................134

4.5.1 Reference specimen and expression to evaluate the recovery......................... 134

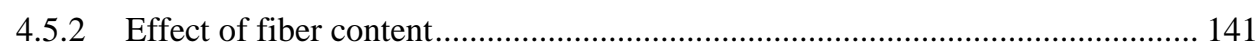

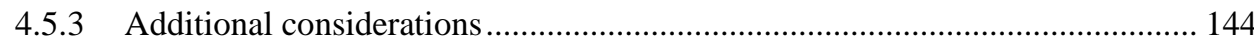

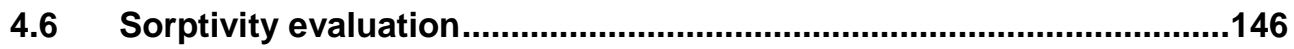

4.6.1 Initial sorptivity values, comparability of the different groups ........................ 146

4.6.2 Effect of healing conditions and preconditioning on sorptivity measurement.. 147

4.7 Summary of conclusions about the methods for the self-healing

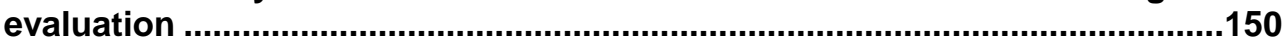




\section{CHAPTER 5. EFFICIENCY OF AUTOGENOUS HEALING AND AUTONOMOUS HEALING WITH CRYSTALLINE ADMIXTURES ...155}

5.1 Introduction . .157

5.2 Influence of several parameters on self-healing by means of crack closing and water permeability ...................................................................157

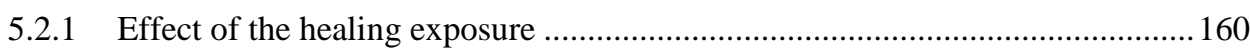

5.2.2 Effect of water/cement ratio and cement content.............................................. 169

5.2.3 Comparison between parameters ................................................................. 172

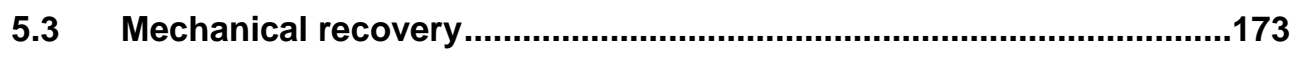

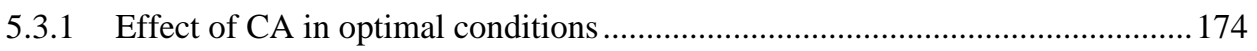

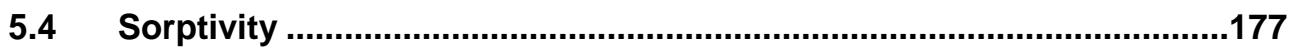

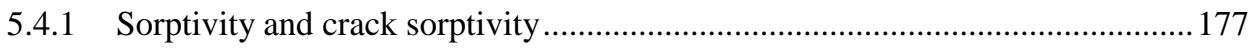

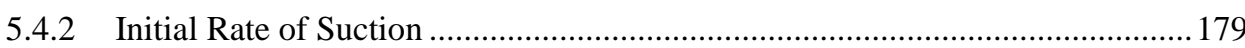

5.5 Further insights about the healing reactions ....................................181

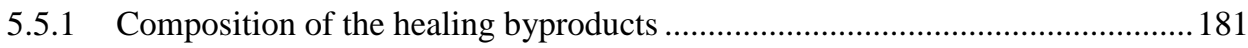

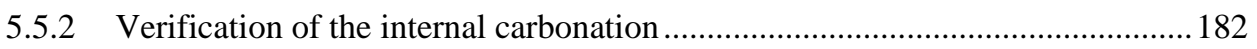

5.6 Discussion and conclusions about the effectiveness of autogenous healing and crystalline admixtures ................................................................184

CHAPTER 6. CONCLUSIONS …..............................................187

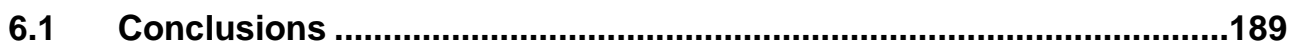

6.1.1 Conclusions on the methodologies to characterize self-healing ........................ 189

6.1.2 Conclusions on the self-healing efficiency using crystalline admixtures ...........191

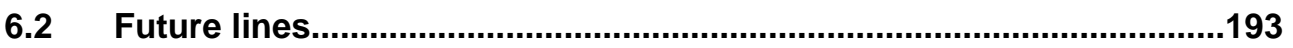

6.3 Publications derived from this thesis .............................................194

REFERENCES .......................................................................... 197 


\section{List of tables}

Table 1-1. Properties of "ideal" and "minimal" self-healing materials. Adapted from (Van der Zwaag, 2007).

Table 2-1. List of parameters that may influence autogenous healing, arranged by type.... 17

Table 2-2. Maximum healable crack width by autogenous healing according to different publications

Table 2-3. Classification of the known options for the three components of autonomous self-healing: healing agent, catalyst, and introduction method.

Table 2-4 - Advantages and disadvantages of commonly used methods to evaluate crack closing.

Table 2-5. Summary of advantages and disadvantages of each described design for achieving self-healing concrete.

Table 2-6. Summary of advantages and disadvantages of methods the evaluation of selfhealing

Table 3-1. Base composition of the concrete types used in this work. .............................. 71

Table 3-2. Oxide composition of two of the used CA. * values from (Sisomphon et al., 2013).

Table 3-3. Exposure conditions of interest and simulation in the laboratory. ..................... 73

Table 3-4. Average and std. deviation for compressive strength and slump test................ 94

Table 3-5. Values of diameter obtained with the mini slump test...................................... 95

Table 3-6. Composition used for the mortars of the calorimetry........................................ 98

Table 4-1. List of studies performed regarding the validation of the crack closing methods.

108

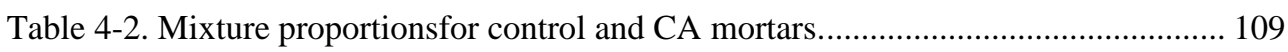

Table 4-3. Mixture proportionsused for the tests. .............................................................. 115

Table 4-4. List of studies performed regarding the validation of the water permeability

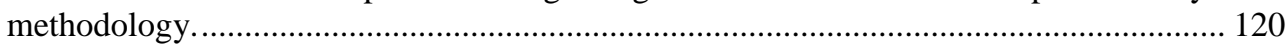

Table 4-5. Mixture proportionsused for the tests. ........................................................ 121

Table 4-6. Mixture proportions used for the tests. ........................................................... 123

Table 4-7. Fitted polynomial cubic trend lines for the two best methods......................... 129

Table 4-8. List of experimental studies performed for the validation of the mechanical

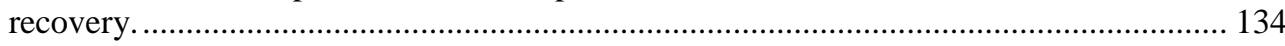

Table 4-9. Mixture proportions and its properties.......................................................... 135

Table 4-10. Experimental program for the campaign to analyze reference specimens. .... 135

Table 4-11. Formula of Stiffness Recovery without a reference. .................................... 137 
Table 4-12. Formula of Stiffness Recovery with a reference......................................... 138

Table 4-13. Composition of the four high quality concrete types used in this campaign. .141

Table 4-14. Mixture proportions for control and CA mortars. ........................................ 146

Table 4-15. Initial sorptivity values of uncracked reference mortar specimens at the age of 7

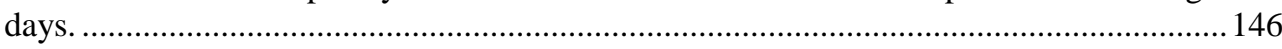

Table 4-16. Initial sorptivity values of mortar specimens precracked at the age of 7 days.

Table 4-17. Initial sorptivity values of uncracked reference mortar specimens at the age of 2

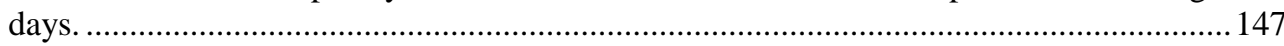

Table 4-18. Initial sorptivity values of mortar specimens precracked at the age of 2 days.

Table 5-1. Composition of the four concrete types used in this campaign......................... 157

Table 5-2. Experimental program for the evaluation of the mechanical recovery. ............ 174

Table 5-3. Results of the evaluation of the stiffness recovery........................................ 176

Table 5-4. Results of the evaluation of the regain of area. ................................................ 176 


\section{List of figures}

Fig. 1-1. Publications per year containing the words "self-healing materials", "self-healing polymers" or "self-healing concrete", data extracted from Google Scholar at $16^{\text {th }}$ of November of 2017.

Fig. 2-1. Structure of the state of the art chapter............................................................. 12

Fig. 2-2. Causes for autogenous healing (De Rooij et al., 2013). ..................................... 14

Fig. 2-3. Surface- and diffusion- controlled process of healing by carbonation (Edvardsen, 1999).

Fig. 2-4. Cracked specimen (left) and zoom of the crack (right) showing the products formed in cracks and the original boundary (Huang et al., 2014).

Fig. 2-5. Relationship between water flow and time for different crack widths (Edvardsen, 1999).

Fig. 2-6. Evolution with time of permeability-measured self-healing under constant loading (LP2) and cyclic loading (LP3) for NSC and FRC specimens (Desmettre \& Charron, 2012).

Fig. 2-7. New crack paths and old healed cracks with white precipitates (Yang et al., 2009).

Fig. 2-8. Methodology to measure the thickness of the precipitates (Nishiwaki et al., 2012).

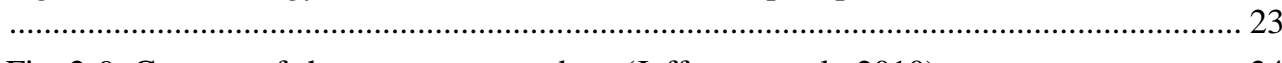

Fig. 2-9. Concept of shape memory tendons (Jefferson et al., 2010)................................. 24

Fig. 2-10. Partial crack healing after water curing (Qian et al., 2009)............................... 25

Fig. 2-11. Decrease of normalized flow rate with time for different crack widths and water temperature at healing (Reinhardt \& Joss, 2003)............................................................ 28

Fig. 2-12. Decrease of healing rate for different crack widths and water pressures (Edvardsen, 1999).

Fig. 2-13. Process of breakage of a microcapsule and release of healing agent (left) and a broken microcapsule (right) (White et al., 2001).

Fig. 2-14. Main forces acting on autonomic healing using located tubes (Joseph et al., 2010)

Fig. 2-15. Mechanism of superabsorbent polymers (Imperial College London, 2012)...... 33

Fig. 2-16. Swollen SAP in crack (left) and crack after drying for 24 hours (Lee et al., 2016)

Fig. 2-17. Comparison of the permeability reduction achieved by different permeabilityreducing admixtures (ACI Committee 212, 2010).

Fig. 2-18. Glass tubes in a bridge deck (Dry, 2000). 
Fig. 2-19. Load-crack width curves for virgin and healed specimens (Van Tittelboom et al., 2012).

Fig. 2-20. Left: Filling glass capsules with the healing material (Kanellopoulos et al., 2015), and right: Scanning electron microscope image of a broken microcapsule (Giannaros et al., 2016)

Fig. 2-21. Left: Endospore formation from bacillus cohnii (Jonkers \& Schlangen, 2007))

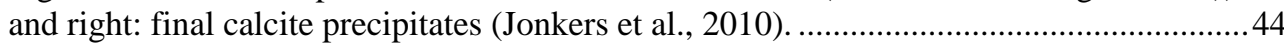

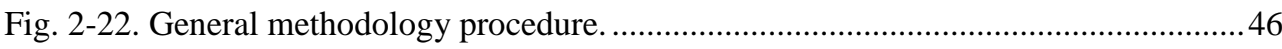

Fig. 2-23. Three-dimensional images of concrete showing the healing agent released inside the crack in yellow, from (Van Tittelboom et al., 2013) and (Van Tittelboom et al., 2011).

Fig. 2-24. Self-healing quantification method used in (Jaroenratanapirom \& Sahamitmongkol, 2011), (Sisomphon et al., 2012), (Van Tittelboom et al., 2012).

Fig. 2-25. Testing device for producing tensile cracks under water pressure (Edvardsen, 1999).

Fig. 2-26. Permeability test as used by (Sisomphon et al., 2012).......................................52

Fig. 2-27. Left: water permeability test setup used by (Aldea et al., 1999). Right: water permeability test setup used by (Jiang et al., 2015).

Fig. 2-28. Air-flow setup with a sectional view of the permeability cell (Gagné \& Argouges, 2012)

Fig. 2-29. Left: waterproof paint isolating the zone of the crack as used by Wang, et al. (2012). Right: test setup used by (Jiang et al., 2015).

Fig. 2-30. Three points (left) and four points (right) bending tests setup (Granger et al., 2007) and (Snoeck et al., 2014).

Fig. 2-31. Stiffness recovery of specimens cracked after 10 weeks of healing (Granger et al., 2007)

Fig. 2-32. Diagram with the curves and parameters involved for the evaluation of selfhealing.....

Fig. 2-33. Test setup of uniaxial tensile test and parameter to evaluate healing (Homma et al., 2009)

Fig. 2-34. CT-scan images of the damaged areas during the pull-out test for hooked fibers (Kim et al., 2014).

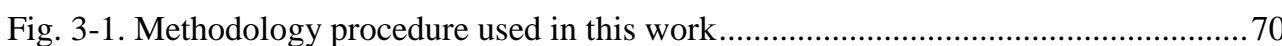

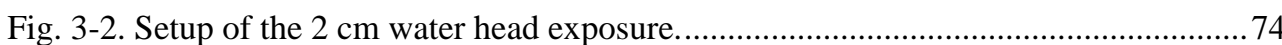

Fig. 3-3. Specimens under six exposures: air exposure (a), humidity chamber (b), water contact (c) wet/dry cycles (d), water immersion at $15^{\circ} \mathrm{C}$ (e) and water immersion at $30^{\circ} \mathrm{C}$ (f).

Fig. 3-4. Concrete specimen and optical USB microscope (left) and mortar specimen in the Leica stereomicroscope (right).

Fig. 3-5. Panorama of a top crack and grid marking the measuring points. 
Fig. 3-6. Panorama of a top crack (top picture) and its black pixels (bottom picture)........ 77

Fig. 3-7. Precracking process and precracked specimen by splitting test. ......................... 79

Fig. 3-8. Sealing of lateral cracks and upper ring with epoxy resin................................. 79

Fig. 3-9. Diagram of the permeability test for cracked specimens. .................................. 80

Fig. 3-10. Permeabilimeter (a) and its parts: manometer (b), sealing ring (c), auxiliary

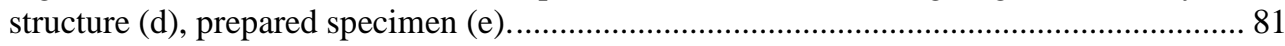

Fig. 3-11. Diagram with a classification of the different reference possible parameters..... 82

Fig. 3-12. Diagram with the parameters of interest for the evaluation of self-healing. ....... 83

Fig. 3-13. Diagrams with the different possible scenarios regarding mechanical recovery. 84 Fig. 3-14. Setup for the three point bending test (left) and detail of the notch and a crack (right)

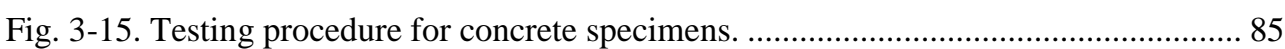

Fig. 3-16. Example of three point bending test of a specimen at precracking. .................... 86

Fig. 3-17. Example of three point bending test of a specimen at precracking (top) and reloading after healing (bottom).

Fig. 3-18. Example load ranges for the calculation of the regression line for the stiffness. 87

Fig. 3-19. Example of evaluation of the regain of energy................................................ 88

Fig. 3-20. Testing procedure for concrete and accompanying specimens. .......................... 88

Fig. 3-21. Cleaning steel plates (left) and attachement in the specimens (right)................ 90

Fig. 3-22. Testing procedure for concrete and reference specimens.................................. 90

Fig. 3-23. Aluminum tape covering specimens except the crack area (left) and sorptivity

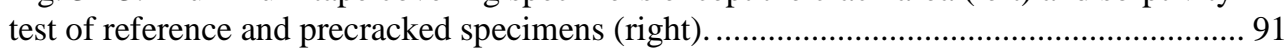

Fig. 3-24. Diagram of the water suction during the sorptivity test. ................................... 91

Fig. 3-25. Example of water absorption curves, uncracked (left) and precracked (right)

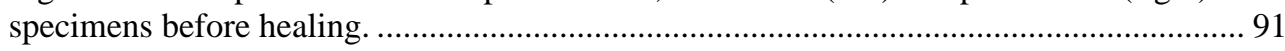

Fig. 3-26. Cumulative absorbed volume vs. square root of time. ....................................... 92

Fig. 3-27 - Slump test following UNE EN 12350-2:2009. ............................................... 93

Fig. 3-28. Avg. compressive strength (bars) and slump (diamonds) with and without $4 \%$ of

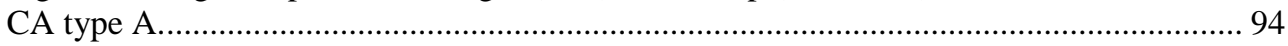

Fig. 3-29. Avg. compressive strength with $2 \%$ of CA type A, and increasing amounts of CA type $\mathrm{B}$ (left) and with different contents of fibers and $8 \%$ of CA type $\mathrm{C}$ (right)................ 95

Fig. 3-31. Appearance of the two mixes after 15 compacting steps. ................................... 96

Fig. 3-32. Compressive strength of mortar cubes (left) and CA mortar cube broken at 2 days

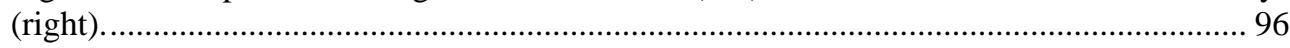

Fig. 3-33. Compressive strength evolution with age for Control and CA mixes................. 97

Fig. 3-34. Average compressive strength per mixing group for control mixes. .................. 97

Fig. 3-35. Average compressive strength per mixing group for CA mixes. ....................... 98 
Fig. 3-36. Materials used for the calorimetry (left), use of a syringe for measuring the amount of water (center) and manual mixing of the compounds (right)....

Fig. 3-37. Recipients inside the calorimeter (left) and computer and calorimeter set up (right).

Fig. 3-38. Heat flow of control sample.

Fig. 3-39. Heat flow results for crystalline admixture type A for the first 72 hours compared with the control sample.

Fig. 3-40. Heat of hydration results for crystalline admixture type A for the first 72 hours compared with the control sample.

Fig. 3-41. Heat flow results for the crystalline admixture type D for the first 72 hours compared with the control sample.

Fig. 3-42. Heat of hydration results for the crystalline admixture type D for the first 72 hours compared with the control sample.

Fig. 4-1. Points defined to take the images and position of the specimen with the crack in repose.

Fig. 4-2. Photos of crack closing at different ages for the three exposures for lateral cracks.

Fig. 4-3. Photos of crack closing at different ages for the three exposures for top cracks. 111

Fig. 4-4. Top crack of a control specimen healed in $\mathrm{HC}$ for 7 days. 112

Fig. 4-5. Precipitates in the bottom crack of a CA specimen after 7 days of healing in WI.

Fig. 4-6. Bottom crack of a CA specimen after 7 days of healing in WI.

Fig. 4-7. Photos of cracks at different times of healing, for cracks produced at the age of 3 days.

Fig. 4-8. Photos of cracks at different times of healing, for cracks produced at the age of 7 days.

Fig. 4-9. Photos of cracks at different times of healing, for different sizes and exposures.

Fig. 4-10. Picture of a crack in a specimen healed in humidity chamber, without precipitates.

Fig. 4-11. Presence of tooth-like precipitates in specimens healed under water immersion.

Fig. 4-12. Crack width (left) and closing rate (right) evolution with time for specimens under the three healing exposures

Fig. 4-13. Final values of crack closing tests after 42 days healing in the different exposures.

Fig. 4-14. Repeatability of the high-pressure water permeability test. Each color corresponds to one different specimen.

Fig. 4-15. Average variations of one water permeability measurement with respect to the previous. 
Fig. 4-16. Water permeability evolution with time for specimens using intermediate tests (left) or only initial-final tests (right).

Fig. 4-17. Water permeability evolution with time for specimens precracked at the age of 3 days (left) and at the age of 2 months (right), when performing intermediate water permeability tests.

Fig. 4-18. Water permeability evolution with time for specimens precracked at the age of 3 days (left) and at the age of 2 months (right), when performing only initial and final water permeability tests.

Fig. 4-19. Cuts performed in concrete specimens to verify internal healing. .................... 126

Fig. 4-20. Specimen with a transversal cut showing no precipitates in the internal part of the

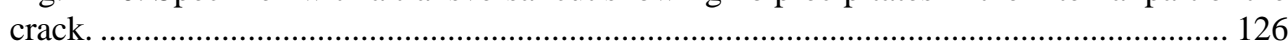

Fig. 4-21. Healing Ratios obtained in specimens with perfect healing............................. 127

Fig. 4-22. Internal healing ratio by water permeability................................................... 127

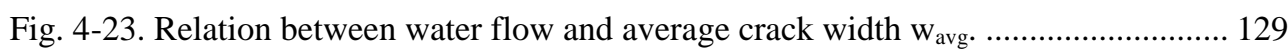

Fig. 4-24. Relation between water flow and estimated crack area $\mathrm{A}_{\text {est }}$............................ 129

Fig. 4-25. Relation between water flow and maximum crack width $\mathrm{w}_{\max }$......................... 130

Fig. 4-26. Relation between water flow and the number of black pixels $A_{p x}$................... 130

Fig. 4-27. Comparison of initial and final (after 42 days) values of water flow versus crack width.

Fig. 4-28. Comparison water flow and crack width relation obtained with the results from (Edvardsen, 1999).

Fig. 4-29. Initial crack width versus initial water flow with differently-adjusted trendlines.

Fig. 4-30. Testing procedure for concrete specimens and both kinds of accompanying specimens.

Fig. 4-31. Top row: Load-displacement curves for Campaign 1, specimens healed in humidity chamber (left) and in water immersion at $30^{\circ} \mathrm{C}$ (right). Bottom row: Loaddisplacement curves for Campaign 2, reference specimens (left) and healed in water immersion at $30^{\circ} \mathrm{C}$ (right).

Fig. 4-32. Stiffness recovery by direct comparison with initial values, SR1 (top), comparison with specimens at Humidity Chamber, SR2 (bottom left), and with accompanying uncracked specimens, SR3 (bottom right).

Fig. 4-33. Stiffness recovery by direct comparison with initial values, SR1 (top), and by comparison with specimens at Humidity Chamber, SR2 (bottom left), and with accompanying uncracked specimens, SR3 (bottom right).

Fig. 4-34. Average and std. dev. values of stiffnes for the precracing and healed specimens.

Fig. 4-35. Avg. and std. dev. values of stiffnes for the precracing, healed and reference specimens.

Fig. 4-36. Precracking and reloading curves for the control high quality concrete. 
Fig. 4-37. Precracking and reloading curves for the CA high quality concrete. ................ 143

Fig. 4-38. Stiffness recovery depending on the fiber content and CA presence.................. 144

Fig. 4-39. Example of healed specimen with stiffness recovery. ..................................... 145

Fig. 4-40. New crack path produced at reloading after healing....................................... 145

Fig. 4-41. Results of sorptivity for control (upper row) and CA (bottom row) specimens. 148 Fig. 4-42. Average results of crack sorptivity for control (left) and CA (right) specimens.

Fig. 4-43. Average results of crack sorptivity for control specimens precracked at 2 and 7

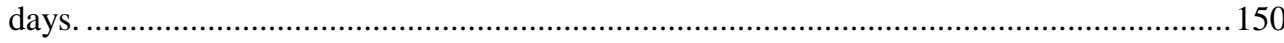

Fig. 5-1. Diagram showing the number of specimens analyzed per group. ....................... 158

Fig. 5-2. Structure for displaying the results of water permeability and crack closing..... 159

Fig. 5-3. Healing Ratio vs. initial water flow of specimens with w/c of 0.45 for all the exposures.

Fig. 5-4. Closing Ratio vs. initial crack width of specimens with w/c of 0.45 for all the exposures.

Fig. 5-5. Detail of Fig. 5-3, Healing Ratio vs. initial water flow of control and CA specimens in exposures without direct contact with water, with w/c of 0.45 and small cracks.

Fig. 5-6. Detail of Fig. 5-3, Healing Ratio vs. initial water flow of control spec. with w/c of 0.45

Fig. 5-7. Detail of Fig. 5-3, Healing Ratio vs. initial water flow of CA specimens with w/c of 0.45

Fig. 5-8. Detail of Fig. 5-4, Closing Ratio vs. initial crack width of control spec. with w/c of 0.45

Fig. 5-9. Detail of Fig. 5-4, Closing Ratio vs. initial crack width of CA specimens with w/c of 0.45 .

Fig. 5-10. Healing Ratio vs. initial water flow of specimens stored under WI at $15^{\circ} \mathrm{C}$ with w/c of 0.45 .

Fig. 5-11. Closing Ratio vs. initial crack width of spc. stored under WI at $15^{\circ} \mathrm{C}$ with w/c of 0.45 .

Fig. 5-12. Detail of Fig. 5-1 for specimens with small initial water flow in water immersion at $15^{\circ} \mathrm{C}$

Fig. 5-13. Healing Ratio vs. initial water flow of specimens stored under WI at $30^{\circ} \mathrm{C}$ with w/c of 0.45 .

Fig. 5-14. Healing Ratio vs. initial water flow of specimens stored under WI at $15^{\circ} \mathrm{C}$ with w/c of 0.60 .

Fig. 5-15. Closing Ratios vs. initial crack width of specimens stored under water immersion at $15^{\circ} \mathrm{C}$ 
Fig. 5-16. Healing Ratio vs. initial water flow of control specimens stored in WI_15 with w/c of 0.45 and 0.60. Results combined from Fig. 5-10 and Fig. 5-14

Fig. 5-17. Healing Ratio vs. initial water flow of CA specimens stored in WI_15 with w/c of 0.45 and 0.60. Results combined from Fig. 5-10 and Fig. 5-14.

Fig. 5-18. Healing Ratio vs Closing Ratio for control and CA specimens with w/c ratio of 0.45 exposed to water immersion at $15^{\circ} \mathrm{C}$ and exposed to WD cycles.

Fig. 5-19. Healing Ratio vs Closing Ratio for control (left) and CA (right) specimens with w/c ratio of 0.45 and 0.60 , exposed to water immersion at $15^{\circ} \mathrm{C}$.

Fig. 5-20. Average and standard deviation values for precracking, unloading (tangent) and reloading slopes for control specimens.

Fig. 5-21. Average and standard deviation values for precracking, unloading (tangent) and reloading slopes for specimens with $8 \%$ of CA type B............................................... 175

Fig. 5-22. Average results of crack sorptivity for control specimens. .............................. 178

Fig. 5-23. Average and std. deviation results of crack sorptivity for CA specimens......... 178

Fig. 5-24. Average results of crack sorptivity improvement for control and CA specimens.

Fig. 5-25. Average results of Initial Rate of Suction for control (left) and CA (right) specimens.

Fig. 5-26. Sorptivity evolution with measurements for precracked specimens healed underwater for control (left) and CA (right) groups.

Fig. 5-27. Sorptivity evolution with measurements for precracked specimens healed underwater for control (left) and CA (right) groups.

Fig. 5-28. Cutting procedure for concrete specimens 181

Fig. 5-29. Specimens after the application of the phenolphthalein indicator. 182

Fig. 5-30. Sealed disks (left) and broken half of a disk after the phenolphthalein test (right). 


\title{
List of abbreviations and notation
}

\author{
Institutions: \\ ACI American Concrete Institute \\ RILEM Réunion Internationale des Laboratoires et Experts des Matériaux, \\ systèmes de construction et ouvrages \\ $\mathrm{TC}$ \\ Technical Committee
}

Concrete types and materials:

$\begin{array}{ll}\text { ECC } & \text { Engineered Cementitious Composite } \\ \text { FRC } & \text { Fiber-Reinforced Concrete } \\ \text { HPC } & \text { High-Performance Concrete } \\ \text { HPFRCC } & \text { High-Performance Fiber-Reinforced Cementitious Composite } \\ \text { HPSFRC } & \text { High Performance Steel-Fiber-Reinforced Concrete } \\ \text { HQ FRC } & \text { High Quality Fiber-Reinforced Concrete } \\ \text { PVA } & \text { Polyvinyl Alcohol } \\ \text { PVC } & \text { Polyvinyl Chloride } \\ \text { SHCC } & \text { Strain-Hardening Cementitious Composites } \\ \text { SMM } & \text { Shape Memory Materials } \\ \text { UHPC } & \text { Ultra-High Performance Concrete } \\ \text { UHPFRC } & \text { Ultra-High Performance Fiber-Reinforced Concrete }\end{array}$

Cement chemistry:

$\mathrm{CH}$

Calcium Hydroxide

$\mathrm{CSH}$

Calcium Silicate Hydrate gel

MH Magnesium Hydroxide

MS Magnesium Silicate 
Concrete compounds and parameters:

BFS Blast Furnace Slag

CA Crystalline Admixture

CSA Calcium Sulfoaluminates

FA Fly Ash

LOI Loss on Ignition

LP Limestone Powder

LWA Lightweight Aggregates

OPC Ordinary Portland Cement

PRA Permeability-Reducing Admixtures

PRAH Permeability-Reducing Admixtures under hydrostatic pressures

PRAN Permeability-Reducing Admixtures under non-hydrostatic conditions

IR Insoluble Residue

SAP Superabsorbent Polymers

SF Silica Fume

w/b water/binder

w/c water/cement

Techniques and devices:

CMOD Crack Mouth Opening Displacement

CT-scan Computerized Tomography scan

LVDT Linear Variable Differential Transformer

SEM Scanning Electron Microscope

TEM Transmission Electron Microscope

XRD X-Ray Diffraction

$\mu \mathrm{CT} \quad$ Micro-Computerized Tomography

Parameters:

A

avg.

CR

CTRL

dev.

HR
Area

Average

Closing Ratio

Control

Deviation

Healing Ratio 


$\begin{array}{ll}\text { i } & \text { cumulative absorbed volume } \\ \text { IRS } & \text { Initial Rate of Suction } \\ \text { K } & \text { Stiffness } \\ \text { KR } & \text { Stiffness recovery } \\ \text { LAR } & \text { Least Absolute Residuals } \\ \text { Lat } & \text { Lateral } \\ \text { P } & \text { Load } \\ \text { Q } & \text { Water flow } \\ \mathrm{R}^{2} & \text { Coefficient of determination } \\ \text { RH } & \text { Relative Humidity } \\ \text { S } & \text { Sorptivity index } \\ \text { std. } & \text { Standard } \\ \text { w } \omega & \text { crack width } \\ \sigma & \text { Stress }\end{array}$

Healing Exposures:

$\mathrm{AE}$

$\mathrm{HC}$

WC

WD

WI

WI_15

WI_30
Air Exposure

Humidity chamber

Water contact

Wet/dry cycles

Water immersion (abbreviated version of WI_15)

Water immersion at $15^{\circ} \mathrm{C}$

Water immersion at $30^{\circ} \mathrm{C}$ 
Chapter 1. Introduction 
Self-healing concrete: efficiency evaluation and enhancement with crystalline admixtures 


\subsection{Background}

Self-healing materials are defined as "man-made materials, which have the built-in capability to repair structural damage autogenously or with the minimal help of an external stimulus." by the RILEM Technical Committee TC 221-SHC of Self-Healing Phenomena in Cement-Based Materials (De Rooij et al., 2013).

The process of self-healing is well-known in natural processes such as those in bones and trees (Speck et al., 2013), which are able to repair damage and recover their pristine properties. New developments for man-made materials try to mimic and adapt these processes.

Even though the first works on self-healing materials date from the late 1940s, the research on this topic was rushed by two turning points. The first is the publication of the research paper "Autonomic healing of polymer composites" in the Nature journal (White et al., 2001), where microcapsules were embedded as vessels for a healing agent in a polymer matrix. The second is the launching of the International Conference on Self-Healing Materials in 2007. From that moment onwards, the popularity of self-healing materials has gradually increased (Fig. 1-1), with the majority of publications being related to polymers until the last years. Recently, this popularity has been transmitted to other materials, such as ceramics, alloys or concrete, but their development has been smaller due to the rigid internal structures of these materials.

\section{Publications 1998-2017}

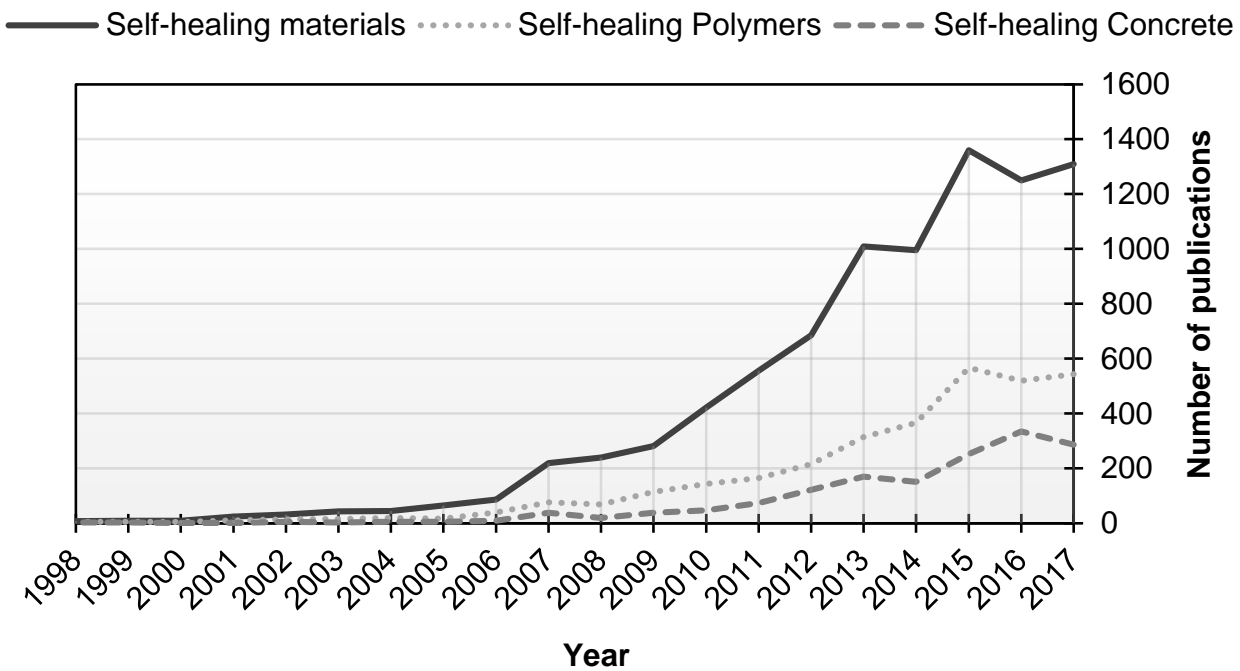

Fig. 1-1. Publications per year containing the words "self-healing materials", "self-healing polymers" or "self-healing concrete", data extracted from Google Scholar at $16^{\text {th }}$ of November of 2017. 
Van der Zwaag (2007) states three roles that are necessary in a self-healing material and their translation at the atomic level:

1. Yield the desired performance: atoms are bonded and stay in place under load

2. Repair the damage: atoms are mobile and can be transferred to the group supporting the load when healing finishes

3. Sense the damage: atoms inform on the state of the material

In the case of concrete, self-healing has been focused on the sealing of cracks and the corresponding recovery of properties. The appearance of small cracks or defects in concrete structures is unavoidable due to its heterogeneous nature. Shrinkage, thermal effects or freeze/thaw cycles are examples of actions that could originate cracks or small defects. These do not necessarily cause a risk of collapse in the structure, but do certainly accelerate its degradation process and diminish its service life. This degradation of the properties could force maintenance operations or the reparation/rehabilitation of the structure. A selfhealing concrete could reduce these maintenance costs, reaching in some cases a competitive position in the market (Van Breugel, 2007).

The use of self-healing materials would probably imply a higher initial cost of the material, but it could result in the diminishing of the maintenance costs and the delay of the repair. A traditional material, without self-healing properties, will need reparation or rehabilitation actions at a certain time, probably after their lifetime. Ideally, a self-healing material would be able to heal itself infinite times and to recover its initial properties perfectly (Van der Zwaag, 2007). Table 1-1 compares the performance requirements for being considered an "ideal" and a "minimal" self-healing material, adapted from (Van der Zwaag, 2007). That author also indicates that current materials are closer to "minimal" self-healing materials than "complete" or ideal self-healing materials.

\begin{tabular}{cc}
\hline An "Ideal" Self-Healing Material & A "Minimal" Self-Healing Material \\
\hline Can heal the damage infinite times & Can heal the damage only once \\
Can heal the damage completely & Can heal the damage partially \\
Can heal defects of any size & Can heal only small sized defects \\
Performs the healing autonomously & Needs external assistance to heal \\
Has equal or superior properties to current & Has inferior properties to current materials \\
materials & Is more expensive than current materials \\
\hline Table 1-1. Properties of "ideal" and "minimal" self-healing materials. Adapted from (Van der Zwaag, \\
2007).
\end{tabular}

Most self-healing materials are at a halfway point between ideal and minimal self-healing materials, and thus, it would be necessary to evaluate the convenience of the additional initial material cost or to assume future repairs for each case.

Structures built with self-healing materials would extend their service life, lower maintenance costs and avoid complicated repairs. Since concrete is the most used material in the construction field, with 25 billion tons manufactured globally each year (Cement Sustainability Initiative, 2009), the search for self-healing concrete is justified by the 
increasing sustainability, security, economy and performance requirements for the materials.

In the concrete field in the 90s, C. Dry already published several designs to achieve selfhealing concrete (Dry, 1994; Dry \& McMillan, 1996; Dry, 2000), but most of the developments on the topic correspond to the last 10 years. Many publications on selfhealing concrete reflect the results of the projects HealCON and Materials4Life, finished in 2016, and the Training Network for Self-Healing Materials: from Concepts to Market (SHeMat), finished in 2015, which were funded with 5.6 million $€$, 44.7 million and 3.8 million $€$, respectively. The main participants of these projects were Universiteit Gent and Technische Universiteit Delft among others (HealCON and SHeMat) and Cardiff, Cambridge and Bath universities (Materials4Life).

Some pilot actions have been built as a result of international research efforts, such as six concrete walls with different self-healing technologies tested onsite in the United Kingdom (Teall et al., 2016) or the first self-healing concrete constructions using bioconcrete developed at TUDelft: a water channel in Ecuador (Sierra-Beltrán \& Jonkers, 2015) and a pilot lifeguard station in The Netherlands (CNN, 2016).

These pilot activities show promising results for the field of self-healing concrete, but there are still some difficulties to tackle. First, the lack of standards for the evaluation of selfhealing either in mortar or in concrete complicates fair comparisons between different selfhealing products. Second, the few commercially available products and the small production scale of some of the most innovative products complicates the preparation of tests at large scale.

In 2016 the RILEM Technical Committee SHE "Self-healing concrete - Its efficiency and evaluation" and the COST Action Sarcos "Self-healing As preventive Repair of COncrete Structures" were launched. These projects show the effort of the scientific community towards the standardization of self-healing products and of evaluation methods for selfhealing. All these projects highlight the current relevance and dynamism of the topic.

The research described in this thesis has been undertaken at the Instituto de Ciencia $y$ Tecnología del Hormigón (ICITECH, Institute of Concrete Science and Technology) of the Universitat Politècnica de València (UPV, Polytechnic University of Valencia). A few experimental campaigns were also performed at the Engineering Department from the University of Cambridge during a short-stay of the $\mathrm{PhD}$ candidate. Chemical analyses were performed at Instituto Eduardo Torroja de Ciencias de la Construcción, from the Spanish National Research Council (CSIC).

\subsection{Objectives}

The main aims of this thesis are to study and develop experimental procedures in order to efficiently evaluate self-healing phenomena and, evaluating experimentally the self-healing enhancements produced when introducing crystalline admixtures in the cementitious matrix. To achieve these purposes, this thesis has the following objectives:

- To compile a state of the art on self-healing concrete, including research on autogenous healing and specific self-healing designs, also named autonomous healing. This part 
will also include the literature review on the use of crystalline admixtures for enhancing self-healing, since they will be used in the experimental work.

- To review different methodologies used in the literature for the evaluation of selfhealing focusing on the methods that evaluate crack closing, evaluation of durability (especially by means of water permeability), and mechanical properties of cracked mortar and concrete specimens.

- To propose methodologies and criteria to evaluate self-healing based on the evaluation of crack closure and the permeability of cracked concrete specimens. This point includes discussion on the appropriateness of different expressions to evaluate selfhealing in these tests and in sorptivity and mechanical tests to evaluate the regain of impermeability and mechanical properties such as the stiffness. The methodologies proposed will be validated experimentally.

- To discern the enhancement of crystalline admixtures on the self-healing capability of concrete from autogenous healing of concrete under different healing conditions, concrete compositions and extent of damage, by using the methodologies proposed in this work.

- To detect and quantify limits on the effectiveness of autogenous healing and crystallineadmixtures-based healing, evaluating the maximum healable damage and the time need for a reasonable healing response.

\subsection{Structure of the document}

This thesis comprises six chapters:

Chapter 1 is the current introductory chapter, which includes background on the selfhealing materials topic and the specific situation of concrete as a self-healing material, the list of objectives to be fulfilled in the thesis and the thesis arrangement.

Chapter 2 reports the state of the art on self-healing concrete, including dedicated sections for autogenous healing and autonomous healing designs. Since this work deals with the appropriateness of the methods for the self-healing efficiency evaluation, there is a specific section reviewing the different evaluation methods for analyzing self-healing.

Chapter 3 describes the methods proposed in this thesis for the evaluation of self-healing in terms of crack closing and water permeability, and presents a discussion on the type of expressions to use in already existing methods for the evaluation of mechanical properties by means of three point bending tests and crack sorptivity.

Chapter 4 presents the outcome of the tests of the experimental phase that focus on the validation of the methodology to evaluate self-healing. This includes studies on specific features such as the most interesting parameter for the crack closing evaluation, repeatability of the water permeability test, and influence of using intermediate permeability tests. Few studies to estimate the needed healing time and best precracking ages to achieve significant healing results are also included. This chapter also compares the use of different expressions for self-healing quantification, among others, in terms of mechanical regain and the sorptivity evaluation. 
Chapter 5. presents the comparison between autogenous healing and self-healing obtained when using crystalline admixtures under different conditions (in terms of crack closing and water permeability). Results will be compared with existing research. This chapter also includes results on mechanical regain, sorptivity, and a specific section for the evaluation of the composition of crystalline admixtures and the precipitates formed in the cracks, and their effect as an admixture for concrete.

Finally, Chapter 6 closes the thesis, summarizing the conclusions obtained in all the experimental campaigns, and provides ideas for further research. 



\section{Chapter 2. An overview of self-healing concrete}


Self-healing concrete: efficiency evaluation and enhancement with crystalline admixtures 


\subsection{Introduction}

This chapter presents the state of the art of self-healing concrete, starting with the present Section 2.1 which includes an introduction and a subsection for explaining the internationally accepted definitions of self-healing, autogenous healing and autonomous healing as used in the concrete field.

To achieve highly durable and sustainable structures is among the most important goals for the civil engineering field. The development of techniques and products that increase concrete durability will reduce maintenance and repair actions of constructions. The matrix of reinforced concrete elements will frequently present small cracks due to the low tensile strength of concrete. These small cracks (under $0.3 \mathrm{~mm}$ ) are not relevant from the mechanical point of view, but they can be an entrance point for different aggressive agents that could initiate degradation processes in the element, such as carbonation of the matrix or corrosion of the reinforcement.

Concrete has a natural self-healing capability for small cracks, named autogenous healing, which is mainly produced by the continuing hydration and carbonation processes (De Rooij et al., 2013). Standard types of concrete have autogenous healing of low effectiveness, reliability and predictability. Because of that, it has not been traditionally considered in the design of concrete structures.

Due to the increasing knowledge and interest on the self-healing properties of concrete, several studies have proposed concrete compositions to improve that natural healing capability, while others and have designed specific products with the main purpose of achieving self-healing, also named as autonomous healing. These self-healing products include, among others the commercial admixtures "crystalline admixtures", micro- or macro-encapsulated agents, and even the use of calcium carbonate-precipitating bacteria.

The effectiveness of these products and their economic viability is still limited though, and because of that they have not been fully adopted in the construction field. Up to date, few prototypes have been built with self-healing properties, an example being the self-healing concrete channel made using bacteria as an addition in Ecuador (Sierra-Beltrán \& Jonkers, 2015). Crystalline admixtures are the most extended commercially available self-healing product, but the lack of knowledge of their behavior limits their applicability.

The methods to evaluate the self-healing capability of mortar and concrete are not standardized. This complicates the assessment of the self-healing response produced in the laboratory and in the aforementioned pilots, and increases the complexity of a critical analysis of the different self-healing products and evaluation methods used in the literature. The experimental methodology chosen to test self-healing will have a notable influence in the obtained results, thus choosing a proper methodology is of great importance to reflect the phenomenon fully and reliably.

This Chapter reviews the state of the art of self-healing in concrete, paying special attention to the topics of autogenous healing, self-healing admixtures and experimental tests to evaluate self-healing in concrete and mortar. Other topics outside the scope of this thesis are also included to provide the reader a general vision of the field. 
The state of the art chapter is divided into five sections (Fig. 2-1). Section 2.1 is the present introductory section, which also includes the internationally accepted definitions in the topic. Section 2.2 explains the processes involved in autogenous healing, focusing on continuing hydration and carbonation but also explaining the influence of several other parameters on autogenous healing. Section 2.3 exposes different designs to achieve autonomous healing in concrete, grouped by the nature of the main healing agent: cement, a chemical agent not naturally found into concrete and biological agents. Section 2.4 reviews different experimental methodologies proposed in the literature to evaluate and quantify the self-healing properties of concrete. The section is divided in four subsections: crack closure, transport properties, mechanical strength and non-destructive tests. Finally, Section 2.5 presents a critical discussion of the concepts seen throughout the whole chapter, including the readiness level of each product and proximity to market.

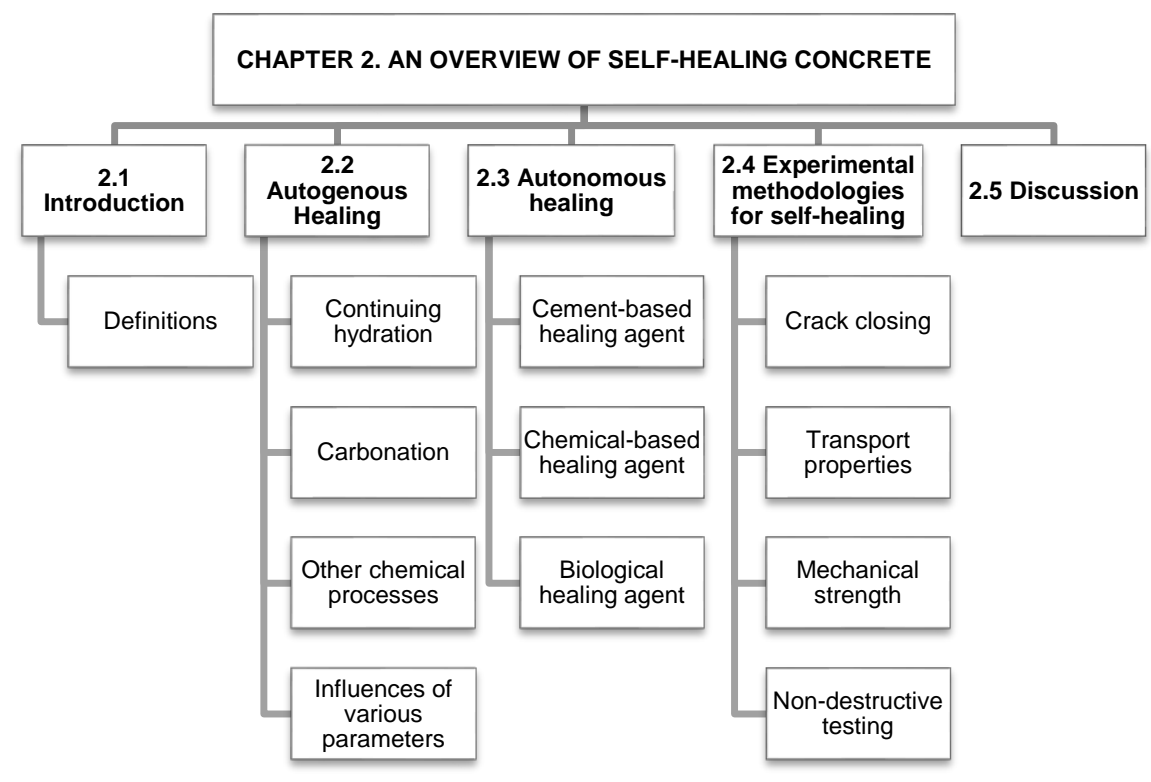

Fig. 2-1. Structure of the state of the art chapter.

\subsubsection{Definition of self-healing}

The literature uses several nomenclatures related to the healing phenomenon, such as selfhealing, self-sealing, self-repairing, or self-closing, depending on the type of properties recovered or other different factors.

According to the definitions of RILEM State-of-the-art of Self-Healing Phenomena in Cement-Based Materials (De Rooij et al., 2013):

Self-healing is any process by the material itself involving the recovery and hence improvement of a performance after an earlier action that had reduced the performance of the material. 
- Autogenic: the self-healing process is autogenic when the recovery process uses materials components that could otherwise also be present when not specifically designed for self-healing (own generic materials).

- Autonomic: the self-healing process is autonomic when the recovery process uses materials components that would otherwise not be found in the material (engineered additions).

In other words, autogenic or autogenous healing of small cracks in concrete is a natural process, intrinsic to the properties of the material itself. Autonomic or autonomous healing is an engineered healing process in order to improve the self-healing properties of a concrete element.

The cases where it is necessary to use of a sensor that shows the results to a technician, who would trigger the healing process, are also considered as self-healing (De Rooij et al., 2013). The difference would lie on the level of intelligence of the material. In contrast, if external material is needed, or the matrix needs to be replaced, the process would not be considered self-healing but repair.

\subsection{Autogenous healing}

The mechanism of autogenous healing in concrete has been known for years. In fact, some of the first mentions of the phenomenon appear in (Neate \& Bowling, 1944) and in (Freyssinet, 1951). In other publications the phenomenon is called cicatrization (Fernández Cánovas, 1994) or natural healing (Mihashi \& Nishiwaki, 2012).

Autogenous healing is mainly caused by continuing hydration of unhydrated cement particles and calcium carbonate precipitation, though other processes could also help it (De Rooij et al., 2013). However, there has been no clear consensus about the level of importance of its different causes. An evidence of that is the lack of a clear differentiation of the chemical processes in the literature and the predominance of carbonation models (Hearn, 1998).

Hearn and Morley (1997) were the first authors who compiled the different mechanisms that were assumed as possible causes for self-healing in concrete. Afterwards those mechanisms have been included in the RILEM State of The Art (De Rooij et al., 2013), being the most extended classification, based on the classification proposed by Ter Heide (2005). These processes are (see also Fig. 2-2):

\section{a. Physical causes:}

- Matrix swelling: increase of volume caused by the saturation of the matrix.

\section{b. Chemical causes:}

- Continued hydration: unhydrated cement particles in contact with water hydrate forming byproducts that fill cracks.

- Calcium carbonate formation: calcium hydroxide (portlandite) in the concrete matrix can react with water, and if it contains carbon dioxide, calcium carbonate is formed as a precipitate filling the crack.

\section{c. Mechanical causes:}

- Sedimentation of fine particles: particles broken off from fracture surface 
- Sedimentation of fine particles: particles from the external water could be transported by the flow and block the crack.

In the literature, continuing hydration and carbonation are considered the main causes for autogenous healing in concrete.

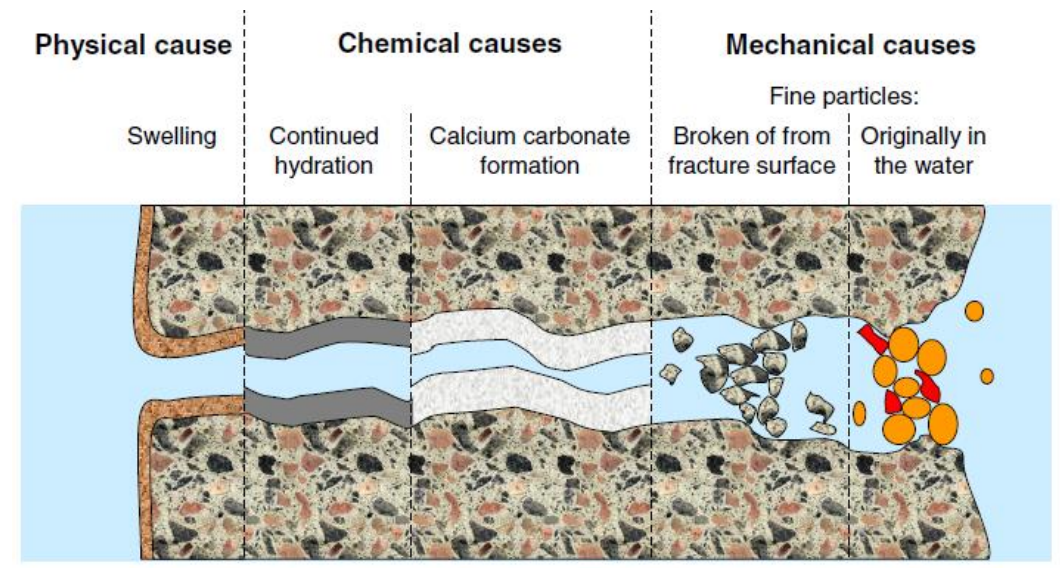

Fig. 2-2. Causes for autogenous healing (De Rooij et al., 2013).

\subsubsection{Continuing hydration effect on autogenous healing}

Continuing hydration effect on self-healing has not received as much attention as carbonation, but its contribution could be of considerable importance (Hearn, 1998).

According to Hearn and Morley (1997) the permeability drop between the initial permeability of young paste and a well-hydrated system caused by hydration can be of four orders of magnitude. In some cases, depending on the water/cement ratio and the availability of external water, the hydration by-products can have around 2 times the volume of cement, (Powers et al., 1954; Neville, 2011), filling spaces that were waterfilled, and thus it can potentially produce crack healing (Giannaros et al., 2016).

In conventional concrete with water/cement ratio around 0.4 , about $30 \%$ of cement particles remain unhydrated, even though, theoretically, that ratio is enough for complete hydration (Van Breugel, 2007). That percentage is increased with coarser cements and higher amounts of cement. Even hydrated cement particles are likely to maintain an inner unhydrated nucleus that experiences slow hydration (years) (Scrivener, 1984). After cracking, if the unhydrated particles get in contact with water (from rain or humidity) hydrate, filling cracks and pores. This process is expected to increase when diminishing the water/cement ratio, as there would remain a higher amount of unhydrated particles.

There are two main differences between the conditions for the chemical reactions in the hydration of cement bulk paste and in a hydration to fill a crack in a specimen, which could change the mineralogy of products (Huang, 2014). First, the water/binder ratio is much higher in cracks with access to external water than in the cement paste, thus there is more water available for the reaction. Second, the free space is much larger in cracked specimens than in the paste. 
There are few studies about the self-healing produced by continuing hydration, as it is necessary to avoid the interaction with other processes, such as carbonation. (Huang et al., 2013; Huang, 2014) used immersed specimens in sealed containers to avoid the entrance of $\mathrm{CO}_{2}$ in the water and then avoiding carbonation. The main minerals of the reaction products obtained in the artificial cracks were calcium hydroxide (portlandite) with a $78 \%$ of mass percentage for specimens under water $\left(80 \%\right.$ under $\mathrm{Ca}(\mathrm{OH})_{2}$ solution) and $\mathrm{C}-\mathrm{S}-\mathrm{H}$ gels, being a $15 \%$ of mass percentage for specimens under water $\left(17 \%\right.$ under $\mathrm{Ca}(\mathrm{OH})_{2}$ solution). The rest of product was identified as calcite. These compounds were produced when the cracked paste was cured in water and in $\mathrm{Ca}(\mathrm{OH})_{2}$ solution, meaning that the initial concentrations of $\mathrm{Ca}^{2+}$ and $\mathrm{OH}^{-}$had not notable influence in the healing processes.

Despite of the influence of continuing hydration on self-healing, several authors agree to affirm that the effect of continuing hydration on autogenous healing is not as important as carbonation (Edvardsen, 1999; Joos, 2001).

\subsubsection{Carbonation effect on autogenous healing}

Carbonation is thought to be the most important process for autogenous healing. It has been noticed for years in structures in contact with water, such as concrete pipes (Wagner, 1974).

Carbonation is produced in concrete when water dissolves and transports the soluble compounds out of the concrete matrix. In few words, when calcium ions from portlandite, $\mathrm{Ca}(\mathrm{OH})_{2}$, contact with carbon dioxide contained in water, they start forming calcium carbonate, $\mathrm{Ca}(\mathrm{CO})_{3}$, following equation (2.1).

$$
\mathrm{Ca}(\mathrm{OH})_{2}+\mathrm{CO}_{2} \rightarrow \mathrm{CaCO}_{3}+\mathrm{H}_{2} \mathrm{O}
$$

In concrete, portlandite is the compound of higher solubility in water. However, the carbonation process affects all the compounds in the hydrated cement matrix: first, the calcium hydroxide, and when that compound becomes depleted, the carbonation of hydrated calcium silicates (C-S-H gels) starts, forming silica gel, which is a high porosity material and suffer even further carbonation (Neville, 2011). Equation (2.2) shows the reaction of carbonation of $\mathrm{C}-\mathrm{S}-\mathrm{H}$ gels from Morandeau, et al. (2014). The exact stoichiometric coefficients of this reaction are not clearly defined; for instance, the amount of water inside the silica gel $\mathrm{SH}_{\mathrm{t}}$ is unknown, as well as the exact kind of calcium carbonate that it forms (calcite, vaterite or aragonite).

$$
(\mathrm{CaO})_{x}\left(\mathrm{SiO}_{2}\right)_{y} \cdot z \mathrm{H}_{2} \mathrm{O}+x \mathrm{CO}_{2} \rightarrow x \mathrm{CaCO}_{3}+y \mathrm{SiO}_{2} \cdot t \mathrm{H}_{2} \mathrm{O}+(z-y t) \mathrm{H}_{2} \mathrm{O}
$$

Unhydrated cement particles with calcium can also suffer direct carbonation, resulting in the formation of calcite and silica gel (Papadakis et al., 1989).

In most studies, the carbonation process is mostly referred to the calcium hydroxide carbonation, due to its much higher solubility in water, and it will be the referred reaction in this work.

Edvardsen (1999) studied the autogenous healing of concrete by analyzing the water permeability, concluding that the precipitation of calcium carbonate was the main cause for autogenous healing, since the main filling fraction was calcite. That study showed two phases of different behavior, a surface-controlled phase and a diffusion-controlled phase (Fig. 2-3). The first phase would be controlled by the presence of ions in the surface of the 
crack, while the second would start when the calcium carbonate layer does not allow direct contact of calcium ions with water, so the process turns dependent on the diffusion of ions from the concrete to the crack. The first phase would take place during the first 3-5 days in contact with the water flow, when crystal growth and crack width reduction are produced. Afterwards, only very slow development of crystal growth and water permeability decrease is produced.
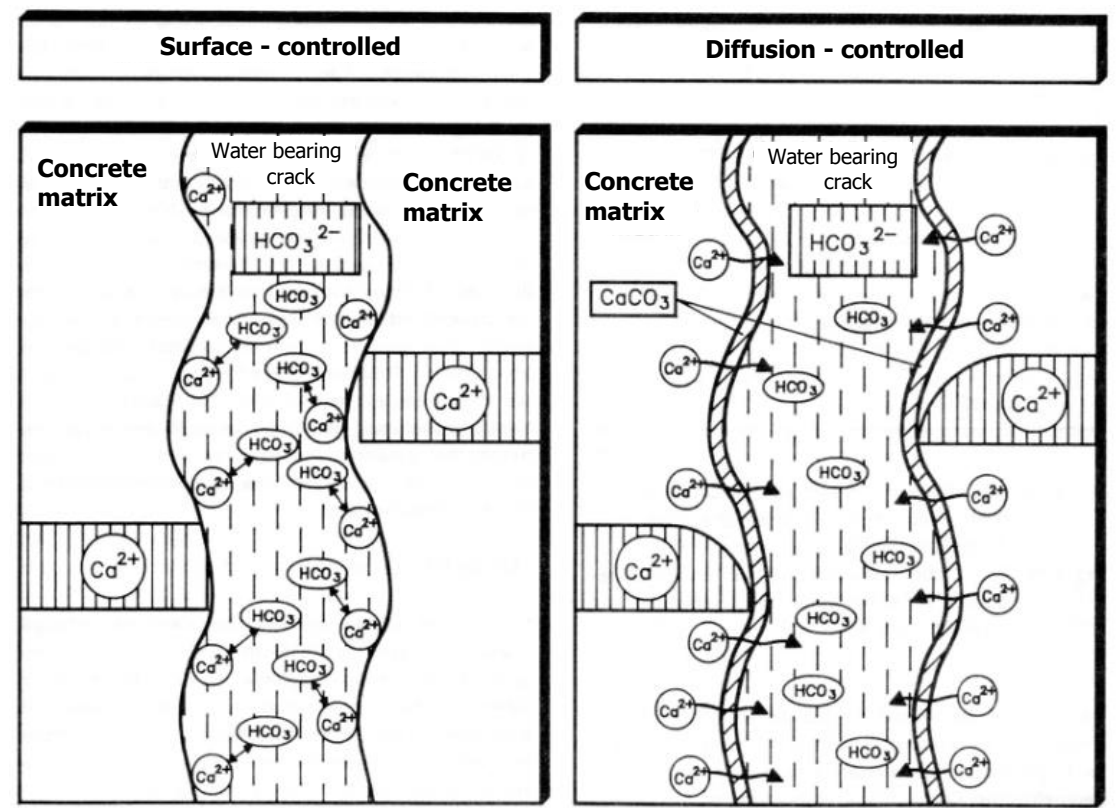

Fig. 2-3. Surface- and diffusion- controlled process of healing by carbonation (Edvardsen, 1999).

This slow decrease with time of the autogenous healing rate produced by carbonation suggests that there is a limit to the effectiveness of this type of self-healing. Once this limit is reached, it is likely that only minor healing will be experienced.

\subsubsection{Other chemical processes that may influence autogenous healing}

The experiments performed by Hearn and Morley (1997) showed a decrease in the concentration of $\mathrm{Mg}^{2+}$ as water flowed through old concrete sample, thus indicating that $\mathrm{Mg}$ ${ }^{2+}$ in the water possibly was reacting with the cement matrix, following the reaction:

$$
C H+M \bar{S}(a q) \rightarrow C \bar{S} H_{2}+M H
$$

The volume increase of this reaction and the precipitation of $\mathrm{MH}$ in the existing pores would also contribute to the sealing of the concrete according to Hearn and Morley (1997). 
Chapter 2. An overview of self-healing concrete

The main causes proposed in the literature for autogenous healing in concrete have been explained in the subsections above. These causes and the extent of autogenous healing are not completely clear and there are still grounds for research.

\subsubsection{Influence of various parameters on autogenous healing}

Several parameters may influence the effectiveness of autogenous healing, such as: crack width opening, cement content, type of cement, etc. This subsection will review these influences focusing on the parameters showed in Table 2-1, classified depending on the type of parameter: composition of the mix, type of damage and healing conditions.

\begin{tabular}{ccc}
\hline Composition & Damage & Healing conditions \\
\hline Water/cement \& cement content & Crack width & Water availability \\
Type of binder \& additions & Age of cracking & Type of water \\
Type of aggregates & Crack kinetics & Water temperature \\
& & Time of healing \\
\hline
\end{tabular}

Table 2-1. List of parameters that may influence autogenous healing, arranged by type.

\subsubsection{Composition: effect of $w / c$ ratio and cement content}

Increasing cement content (and reducing water/cement ratio) is a potential method to improve autogenous healing based on improving continuing hydration contribution.

Some authors investigated the effect of changing w/c ratio on autogenous healing:

- Qian, et al. (2009) compared several mixes increasing water to binder ratio from 0.30 to 0.60 but maintaining constant the water to powder ratio by adding limestone powder, which can be assumed as an inert addition. Their results suggested that the mix with the lowest water/binder ratio and water/powder ratio promoted self-healing.

- Van Tittelboom, et al. (2012) analyzed the composition of concrete mix for two water/binder ratio, 0.40 and 0.50 , for cracks between 50 and $250 \mu \mathrm{m}$. Their study concluded that increasing w/c ratio decreased healing by continuing hydration.

- Gagné and Argouges (2012) investigated the autogenous healing of mortars by means of air-flow permeability through precracked specimens. They analyzed three mixture proportions, with water/binder ratios of $0.35,0.45$ and 0.60 , and it did not discern a clear effect of water/cement ratio on self-healing.

These research show that changing the water/cement ratio produces small effects on autogenous healing, for the ratios comprised inside the standard values for concrete $(\mathrm{w} / \mathrm{c}$ between 0.40 and 0.60). High-performance concrete could have different behavior regarding to self-healing, mostly due to the much higher amount of unhydrated cement particles in its microstructure. Some authors focused only in mixtures with high cement contents:

- In the mid-90s, Jacobsen et al. investigated autogenous healing of high performance concrete with water/binder ratio of 0.40 and silica fume contents between 0 and $5 \%$ by the weight of cement. They achieved clear improvement in terms of resonance 
frequency values but not in terms of strength (Jacobsen et al., 1995; Jacobsen \& Sellevold, 1996). Healing products were observed bridging cracks after the self-healing process, and were identified as C-S-H (Jacobsen et al., 1995). Portlandite and ettringite were observed locally, as well. They analyzed the samples with electronic microscopy and only observed complete filling of the cracks under $5 \mu \mathrm{m}$.

- Granger et al. (2007) analyzed the recovery of stiffness and peak load of UHPC for specimens precracked to have $10 \mu \mathrm{m}$ of residual crack width, achieving stiffness recoveries for specimens healed in water for 10 weeks. The stiffness of the filling products was close to to those of primary $\mathrm{C}-\mathrm{S}-\mathrm{H}$. The slow recovery was thought as caused by the progressive development of the mechanical properties of the new crystals or of the weakness zone between new crystals and primary $\mathrm{C}-\mathrm{S}-\mathrm{H}$.

\subsubsection{Composition: effect of cement type and mineral additions}

The size of the cement particles may influence self-healing based on continuing hydration. $\mathrm{Li}$, et al. (2011) studied the effect of particle size and mixing content of coarse cement on autogenous healing by ultrasonic measurements, showing that for equal mixing content of coarse cement, self-healing ratio increased with the diameter of cement.

The use of mineral additions or blended cements may also produce different autogenous healing effectiveness. The use of Blast Furnace Slag (BFS) has been proposed to enhance autogenous healing due to their delayed hydraulic reaction, which makes more probable that it remains a reaction capability when an early crack appears in concrete. Pozzolanas, such as fly ash (FA) and silica fume (SF), have also been suggested to increase autogenous healing due to their late reaction with calcium hydroxide in the presence of water. Nevertheless, since they consume portlandite, that could decrease the capability of autogenous healing based on carbonation. Limestone Powder (LP) and hydrated lime effect on healing have also been analyzed.

\section{Blast Furnace Slag (BFS)}

Some studies that investigate the effect of BFS on autogenous healing show better healing behavior in mixes that include BFS:

- Zhou, et al. (2011) analyzed the influence of slag contents of 20\%, 30\%, $40 \%$ on selfhealing, resulting in a maximization of healing was maximized when the content of slag was $30 \%$, but with very limited percentages of recovery of compressive strength (around 5-6\% of the initial strength).

- Tittelboom, et al. (2012), concluded that partial replacement of the cement content by BFS, led to an increased crack healing efficiency by the evaluation of water permeability. However, regarding the strength regain all mixes showed low healing potential, with hardly any improvement.

- Sahmaran, et al. (2013) compared fiber-reinforced concrete specimens with OPC and with BFS and more precipitates were observed from the mixture incorporating slag.

- Olivier, et al. (2013) studied the self-healing effect in mortar with BFS cement with a $50 \%$ of replacement compared with Portland cement, when exposed 28 days and 42 days to underwater conditions. They compared optical 2D and 3D measures with tomography in order to evaluate the phenomenon, showing that OPC heals better for 
less than 25 days, but for longer healing times, BFS behaved better, because of its delayed reaction.

- Huang, et al. (2014) investigated the enhancement on autogenous healing by replacing $66 \%$ of cement by blast furnace slag in pastes and activating it with a saturated calcium hydroxide solution. The products were C-S-H gels (higher fraction), ettringite (important presence), and the minerals hydrogarnet $\left(\mathrm{Ca}_{3} \mathrm{Al}_{2}(\mathrm{OH})_{12}\right)$ and $\mathrm{OH}$-hydrotalcite $\left(\mathrm{Mg}_{4} \mathrm{Al}_{2}(\mathrm{OH})_{14} \cdot 3 \mathrm{H}_{2} \mathrm{O}\right)$ The amounts of ettringite showed the leaching and recrystallization of $\mathrm{SO}_{4}{ }^{2-}$ ions. The results suggested that unreacted blast furnace slag in the matrix contributes to self-healing of microcracks when activated by $\mathrm{Ca}(\mathrm{OH})_{2}$ solution. Fig. 2-4 shows the filling products inside cracks in comparison with the original limits of the crack.

- Darquennes et al. (2016) also achieved that mixtures with BFS, added in substitution of cement, achieved more important self-healing capacity in terms of chloride migration. They describe this behavior as produced by their enhanced ongoing hydration at early age and the unhydrated particles located on the cracked surface.
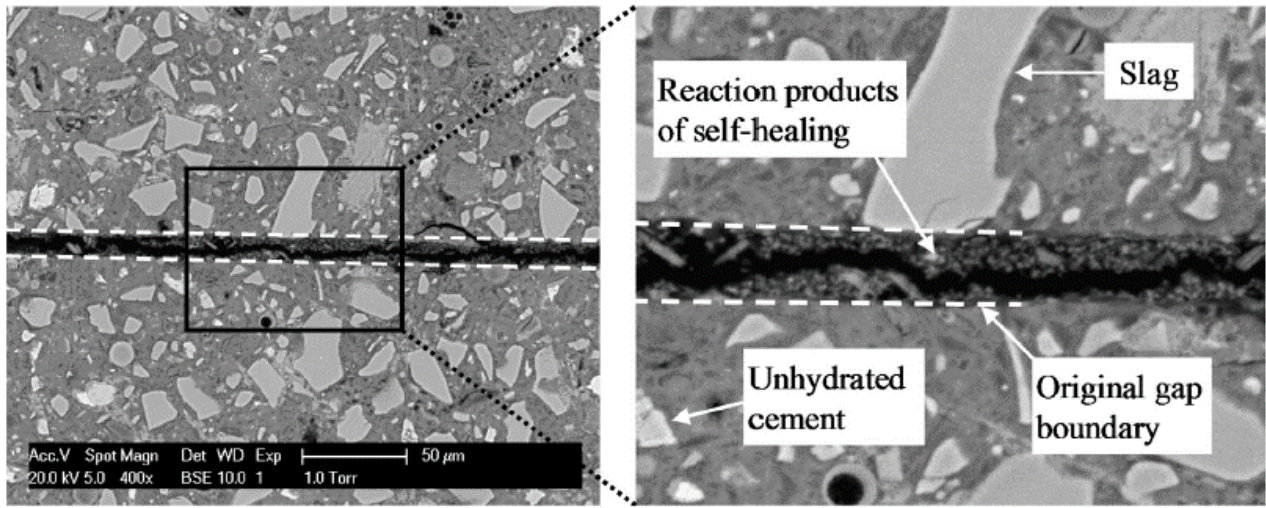

Fig. 2-4. Cracked specimen (left) and zoom of the crack (right) showing the products formed in cracks and the original boundary (Huang et al., 2014).

On the other hand, other publications report little to none improvements. According to Edvardsen (1996; 1999), the type of cement has lesser influence on autogenous healing when comparing Ordinary Portland Cement (OPC), slag and SR cements. Schlangen, et al. (2006) suggested that OPC had some more capacity for crack healing at a later stage compared to concrete with BFS, due to its higher amount of unhydrated cement left in the crack. Palin, et al. (2015) achieved that OPC healed better than BFS cement (healing cracks almost 6 times greater than BFS), but they also experienced severe losses in compressive strength, which did not happen in BFS cement.

\section{Fly Ash (FA)}

Many authors have found FA as an autogenous healing enhancer:

- Termkhajornkit et al. (2009) reported an increase of the self-healing ability when the fraction of fly ash increased by means of compressive strength and porosity, due to the delayed reaction of FA. 
- Zhou, et al. (2011) obtained that an amount of $40 \%$ of FA maximized the self-healing capacity of their concrete in terms of strength.

- Van Tittelboom, et al. (2012) reported slight improvements on the healing capabilities in terms of water permeability, but no strength regains due to further hydration. FA showed less efficiency than BFS.

- Na et al. (2012) analyzed the effect of fly ash blended cement with different cement replacement ratios $(10 \%, 20 \%$, and $30 \%$ by volume) comparing with OPC samples. The results show a notable recovery of all the properties after deterioration for most cases, with higher degree of healing in mortar samples with fly ash (20 and 30\% of replacement).

- Zhang, et al. (2014) compared the three ECC with very large contents of FA by sorptivity, concluding that specimens with the highest fly ash/cement ratio (4.0 by weight) may have the highest self-healing behavior, but it was not evident for intermediate contents.

Other studies found FA as ineffective for improving self-healing or with limited capability. Fly Ash was found to be ineffective to improve self-healing for most cases analyzed by Jaroenratanapirom and Sahamitmongkol (2011). Sahmaran, et al. (2013) compared the selfhealing enhancement by using Fly ash and BFS with OPC, their results show that, although samples with fly ash had more unhydrated cementitious materials (so an expected higher capacity for self-healing), more self-healing precipitates were observed from the mixture incorporating slag.

\section{Other mineral additions}

Jaroenratanapirom and Sahamitmongkol (2011) compared healing by visual closure behavior of several mineral additions. Adding a $10 \%$ of silica fume improved healing for older cracks (28 days), and notably good for early age cracks ( 3 days) of 0.1-0.2 mm. In the case of adding a $10 \%$ of limestone powder, that same study showed improved healing for early age cracks and large size $(0.2-0.3 \mathrm{~mm})$.

Other addition that has been studied is pure hydrated lime (calcium hydroxide). Yildirim, et al. (2014) studied its influence in ECC with high contents of fly ash, comparing hydrated lime contents of $0 \%, 2.5 \%$, and $5.0 \%$, showing that the addition of hydrated lime enhanced precipitation of calcite.

\subsubsection{Composition: effect of the type of aggregates}

The type of aggregates may influence the preferential formation of different compounds in the crack, and the amount of coarse aggregates and its size may also affect the transport of the healing agent to the crack that needs to be healed.

According Edvardsen (1996; 1999), differences on self-healing due to the composition of the aggregate (granite, limestone or basalt) are of lesser influence. The conclusions reached regarding the type of filler, comparing limestone dust and fly ash are similar, indicating lesser influence.

Zhou, et al. (2011) studied the effect of sand/aggregates ratio on strength measurement, as it affects the size particles distribution and the density of concrete. Their study compared the 
compressive strength before and after self-healing, showing very different results for sand ratios of $0.29,0.33,0.37,0.41$, and obtaining the optimal in 0.33 in terms of self-healing.

\subsubsection{Damage: effect of crack width}

Edvardsen $(1996$; 1999) reported that crack width is the most important parameter in selfhealing, since smaller cracks are expected to heal better and in a shorter time. Less healing products are needed to fill small cracks and it is easier for the products to grow and bridge it. Fig. 2-5 shows the results of water flow for a fixed water pressure for different sizes of cracks. These cracks were produced by a special test setup to produce at the same time tensile cracks and perform water permeability tests (this method is further explained in Section 2.4 "Experimental tests to evaluate self-healing in concrete"). The results showed that the larger the crack is, higher water flow passes through the specimen.

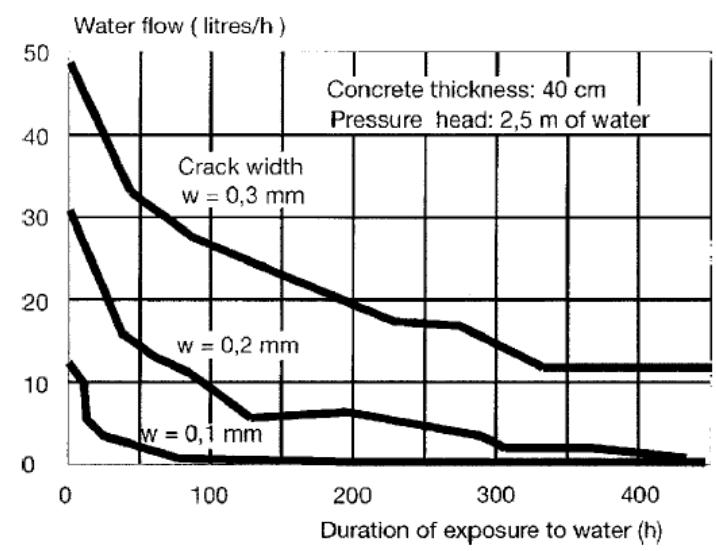

Fig. 2-5. Relationship between water flow and time for different crack widths (Edvardsen, 1999).

Edvardsen (1999) also points out that crack branching would also help in the reduction of water flow by a reduction of the crack width of each branch.

Most of the authors obtained that small cracks heal more easily than larger cracks, Edvardsen (1996; 1999), Reinhardt and Joss (2003), Qian, et al. (2009), Fagerlund and Hassanzadeh (2010), Kim, et al. (2014), Snoeck et al. (2015), among others. However, some publications obtained a minimum crack width that must be reached, because the water that is necessary for the reactions would enter more easily through cracks of a certain magnitude (Zhong \& Yao, 2008; Li et al., 2011). In fact, in a study by Van Tittelboom, et al. (2012) cracks with openings around 0.15-0.2 $\mathrm{mm}$ achieved better healing results than $0.1-0.15$ cracks.

Due to the predominance of studies showing that larger cracks are harder to heal, in general, it is assumed that reducing crack width is a benefit regarding self-healing. Therefore, restricting the damage level or the crack width can be used as a method to improve the self-healing behavior of concrete. There are two main methods to restrict crack width that have been analyzed in order to improve self-healing: the use of fiber reinforced concrete and the application of a compressive strength. 


\section{Fiber-reinforced concrete: SHCC and ECC}

The use of fiber-reinforced concrete to improve autogenous healing has focused on StrainHardening Cementitious Composites (SHCC), alternatively called Engineered Cementitious Composites (ECC). These materials have high volume of fibers, which permit the tensional distribution and a ductile behavior, thus presenting multiple cracking with very small cracks $(<0.05-0.07 \mathrm{~mm})$.

Desmettre and Charron (2012) compared the behavior of normal strength concrete (w/c ratio of 0.6 ) and fiber-reinforced concrete (with silica fume, w/b $=0.43$ ). Fig. 2-6 shows the different evolution of permeability-measured healing for the two types of concrete, proving the benefits of a combination of using fibers and lower w/c ratio.

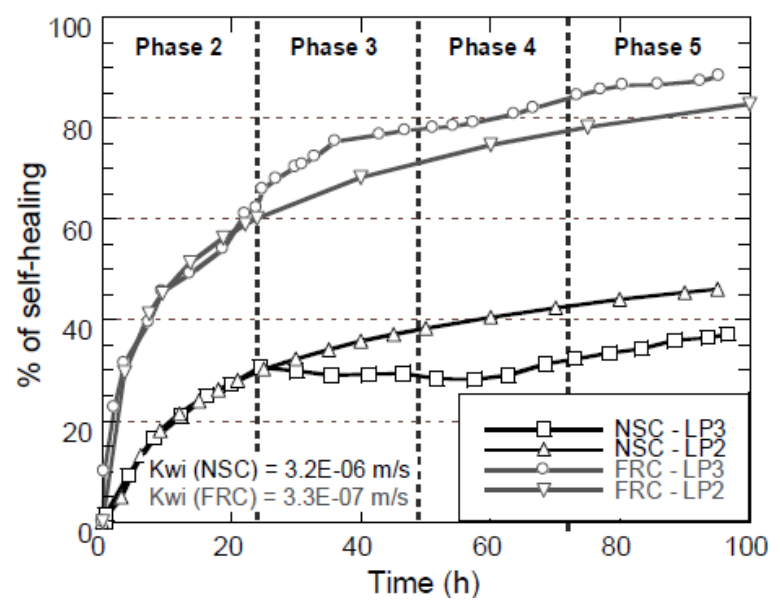

Fig. 2-6. Evolution with time of permeability-measured self-healing under constant loading (LP2) and cyclic loading (LP3) for NSC and FRC specimens (Desmettre \& Charron, 2012).

Yang et al. $(2009 ; 2011)$ showed that ECC healed cracks could be of enough strength that new cracks are produced during the reloading stage, and the self-healed ECC material remained ductile (Fig. 2-7). Their studies showed that, for small damage, specimens healed in cycles of water immersion and drying, recovered resonant frequency and stiffness, concluding that their specimens achieved "true mechanical recovery".
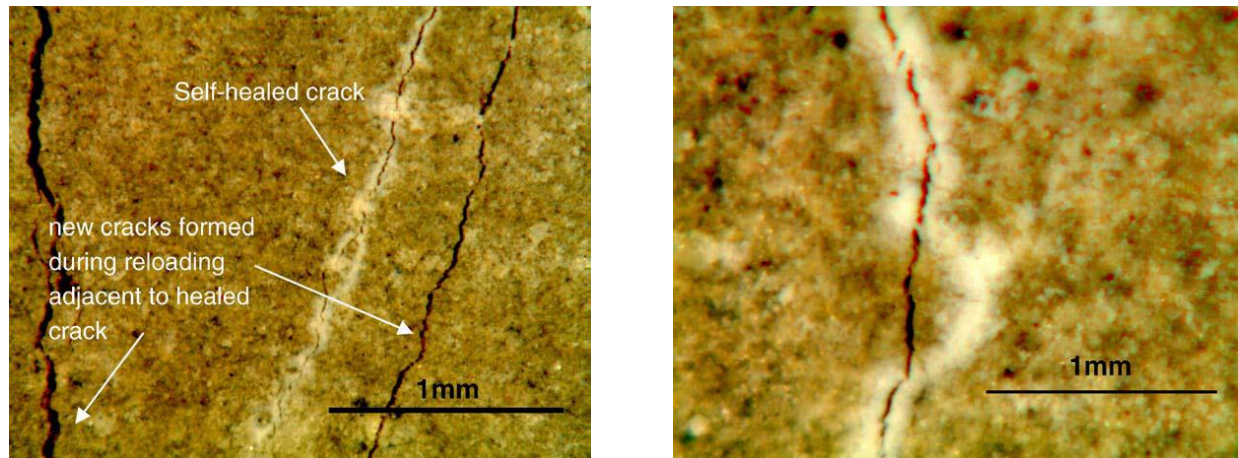

Fig. 2-7. New crack paths and old healed cracks with white precipitates (Yang et al., 2009). 


\section{Effect of the type of fibers}

In Tohoku University, several studies have been published with focus in analyzing the effect on self-healing of the composition of the fiber.

Homma, et al. (2009) compared polyethylene (PE), steel cord (SC) fibers and a composition of both types by measuring the thickness of the precipitates formed in the fiber (Fig. 2-8). Their results showed a better behavior or polyethylene fibers, as they bridged the cracks more efficiently and crystallization products were attached easily to the fibers. In fact, the mean thickness of the precipitates was higher when using PE fibers, and lowest with SC fibers. The precipitates formed inside the crack were mostly calcium carbonate.

Later, they compared the performance of two types of polyvinyl alcohol (PVA-I and PVAII), ethylene vinyl alcohol (EVOH), polyacetal (POM) and two polypropylene (PP and CPP) fibers with similar procedures (Nishiwaki et al., 2012). When measuring the permeability of precracked specimens, those with PP and EVOH fibers did not present a permeability decrease after healing under water, while the rest of types of fibers (including C-PP) had a significant decrease. However, the only type of fiber that allowed a recovery of permeability coefficient values to that of uncracked specimens, were PVA fibers. By 14 days of healing exposure $0.3 \mathrm{~mm}$ cracks were visually closed, except for the PP fibers.

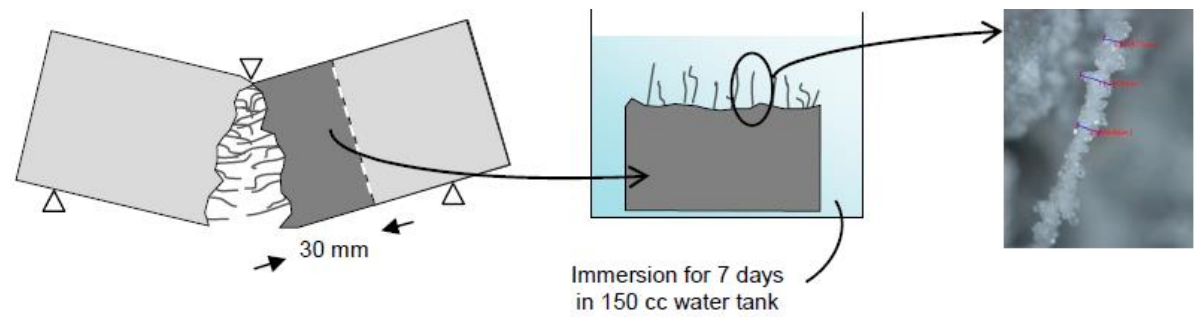
(a) Three-point bending test to split a
specimen into 2 pieces

(b) Immersion of a cut

(c) Measurement of the specimen in water diameter of fibers with

Fig. 2-8. Methodology to measure the thickness of the precipitates (Nishiwaki et al., 2012).

They also measured the thickness of the crystal precipitates in the different types of fibers, in one concrete surface, in order to measure their potential healing effect, achieving better results for PVA fibers. This is thought to be caused by their higher polarity strength owing to the $\mathrm{OH}$ radical, thus enhancing the precipitation of $\mathrm{CaCO}_{3}$ (Nishiwaki et al., 2014).

Snoeck and De Belie (2012) compared cottonised flax and PVA fibers healing under wet/dry cycles and their results were very similar for both types: cracks smaller than 0.03 $\mathrm{mm}$ healed completely but cracks around $0.15 \mathrm{~mm}$ only partly healed. In later studies, Snoeck et al. (2015) compared several types of natural fibers (technical flax, cottonised flax, non-retted hemp and slightly-retted hemp) modified with chemical treatments. These different materials and treatments led to different cracking efficiency, but autogenous healing was independent of the fiber. 
The use of absorbent fibers to enhance continued hydration has been included as an autonomous healing method and is described in subsections "2.3.1.2 Water encapsulation" and "2.3.2.3 Dispersed encapsulation" for other absorbed or encapsulated agents.

\section{Application of a compressive stress}

Ter Heide (2005) studied early age cracks and the effect of applying a compressive stress while healing, as it could bring the two crack faces closer. Three point bending test was used for precracking the specimens to crack widths of $50 \mu \mathrm{m}$, and to analyze the strength regain after healing. The results of this study show that the application of a compressive stress during the healing time improved autogenous healing.

Instead of applying compressive stress as an external action, the use of shape memory materials (SMM) has also been proposed (Jefferson et al., 2010). Shape memory materials have the property of recovering a shape that was stored in their "memory" under certain conditions. The concept of the use of SMM in order to improve autogenous healing is, to add them in a concept similar to prestressed bars: to apply the activator when a crack appears, thus initiating the shrinkage of the SMM which compresses the specimen (Fig. 2-9). Even in the case of needing external activation, these types of mechanisms are also classified as a method to achieve self-healing by the RILEM TC 221 (De Rooij et al., 2013).

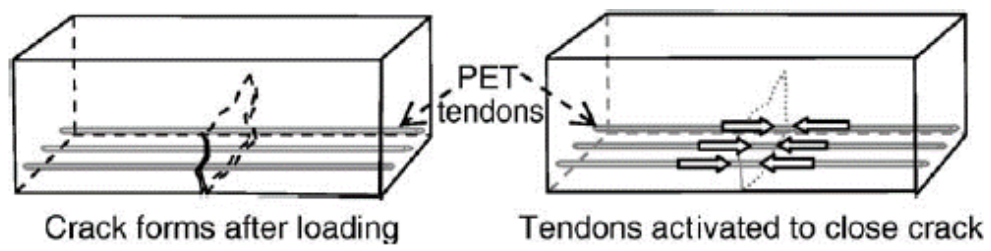

Fig. 2-9. Concept of shape memory tendons (Jefferson et al., 2010).

\section{Crack width limit for autogenous healing}

Regarding the maximum healable crack width, the literature shows high dispersion results. Authors such as Edvardsen (1996; 1999), Fagerlund and Hassanzadeh (2010) or Nishiwaki, et al. (2012) concluded that cracks $0.30 \mathrm{~mm}$ are able to heal by carbonation. Other studies, however, showed autogenous healing capability limited to cracks around $0.05 \mathrm{~mm}$, such as Yang, et al. (2009), Qian, et al. (2009), Snoeck and De Belie (2012), Kim, et al. (2014), as displayed in Fig. 2-10.

Nevertheless, these results need to be analyzed with caution, since the maximum healable crack width will depend also the compositions of concrete (as seen in previous sections), on other damage parameters and on the healing exposure conditions and time (addressed in subsections 2.2.4.7 to 2.2.4.10). Table 2-2 shows the dispersion of the healable crack between different studies. 


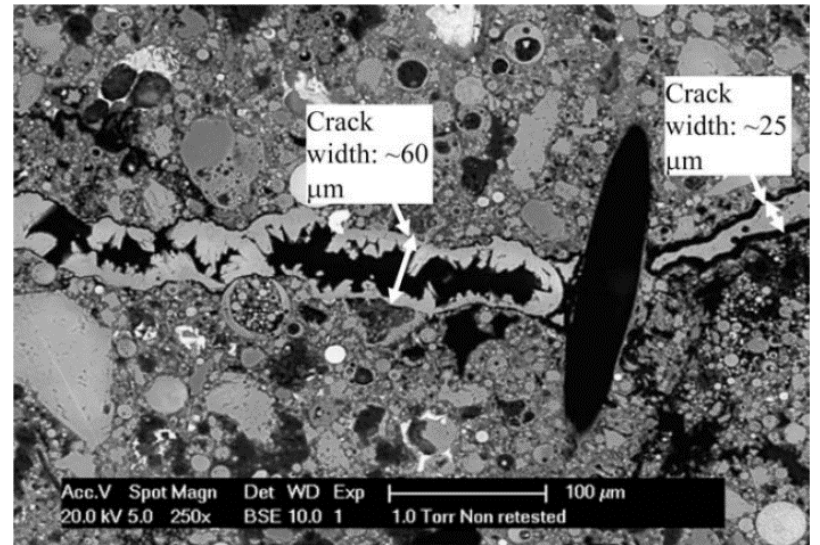

Fig. 2-10. Partial crack healing after water curing (Qian et al., 2009).

\begin{tabular}{ll}
\hline Max. Healable Crack & References \\
\hline$\omega<0.01 \mathrm{~mm}$ & Jacobsen, et al. (1995) \\
\hline & Yang, et al. (2009) \\
& Qian, et al. (2009), see Fig. 2-10 \\
& Snoeck and De Belie (2012), (Snoeck et al., 2015) \\
& Kim, et al. (2014) \\
\hline$\omega=0.05 \mathrm{~mm}$ & Fukuda, et al. (2013) \\
\hline & Reinhardt and Joss (2003) \\
& Van Tittelboom, et al. (2012) \\
$\omega=[0.10-0.20] \mathrm{mm}$ & Jaroenratanapirom and Sahamitmongkol (2011) for mature \\
& cracks \\
\hline & Edvardsen (1996; 1999) \\
$\omega>0.20 \mathrm{~mm}$ & Fagerlund and Hassanzadeh (2010) \\
(tests usually up to & Jaroenratanapirom and Sahamitmongkol (2011) for young \\
$\sim 0.30 \mathrm{~mm})$ & cracks \\
& Nishiwaki, et al. (2012) \\
\hline
\end{tabular}

Table 2-2. Maximum healable crack width by autogenous healing according to different publications

The reasons for such a high dispersion of results for the maximum healable crack indicate the need of further studies to discern the causes of these differences, which can be any of the aforementioned differences in composition, conditions or methods of each study. Those authors indicating healable cracks only in the range of $10-50 \mu \mathrm{m}$ have generally worked with Ultra-High-Performance Fiber-Reinforced Concrete in microcracked state, while those indicating larger healable cracks with diverse concrete compositions and often with a single macrocrack. 


\subsubsection{Damage: effect of age and hydration degree}

Since continuing hydration and carbonation are time-dependent phenomena, the age of the damaged sample is one of the most influencing parameters.

Ter Heide (2005) studied early age cracks and some of the conditions to achieve selfhealing. This study analyzed autogenous healing for cracks generated at 20, 24, 48 and 72 hours and concluded that the extent of crack healing decreases when the crack is formed at a later time. This is coherent with the expected effect by continuing hydration, but not if the main reaction was produced by carbonation.

Gagné and Argouges (2012) compared autogenous healing for cracks generated at the age of 28 days and 6 months for specimens stored at $23^{\circ} \mathrm{C}$ and $100 \%$ of relative humidity for 5 months. Their results show that effective crack opening decreases for all cases and the velocity of healing is higher in the first month, while at $3 / 5$ months healing is still active but at notably lower rates. Moreover, early age cracks (1 month) healed only slightly better than those precracked at older ages (6 months). That could be caused by an almost complete hydration of specimens precracked at 1 month. The reaction products were composed mostly of calcium carbonate.

The quantification of healing by further hydration was performed by analyzing the Back Scattering Electron Microscopy images and measuring the filling area of the natural cracks (Huang, 2014). Different values for the filling fraction of cracks were obtained for the precracking ages and time of healing, with better results for younger cracks and higher healing time.

\subsubsection{Damage: effect of crack motion}

Crack motion is another influencing parameter that may difficult the autogenous healing process. According to Edvardsen (1996; 1999), both, dormant and active cracks are able to heal, but active cracks take longer time. That study showed that, for crack motion corresponding to 1-day cycle, and comparing with dormant cracks, the period for total healing was increased when analyzing their water permeability.

\subsubsection{Healing: water availability}

Since the reactions for autogenous healing need the presence of water, its availability is another critical aspect for self-healing. In general, water immersion has been reported as the best exposure for self-healing and autogenous healing is considered not able to recover properties in air exposure:

- The tests from Wagner (1974) showed that autogenous healing of cracks occurred in contact with flowing and nonflowing. Under nonflowing conditions, self-healing was able to heal completely cracks of $0.05 \mathrm{~mm}$ in 60 days of water immersion, while under flowing-water conditions, cracks of the same size healed in 6 months.

- Granger et al. (2005) analyzed healing in ultra-high performance concrete during 1, 3 or 6 weeks at air exposure or water immersion. Their results showed none regain of mechanical properties when specimens were stored in air, while those stored in water for more than 3 weeks showed stiffness recovery, almost equal to virgin UHPC. 
- Ter Heide (2005), Schlangen, et al. (2006) compared the effect of healing time (from 2 to 12 weeks), relative humidity $(60 \%, 95 \%$ and water immersion). They registered a better response for specimens stored under water immersion in comparison to those in humidity chambers at $95 \%$ or $60 \%$ of relative humidity. Regarding the healing time, between one and two months of water immersion the strength recovery was stabilized.

- Qian, et al. (2009) achieved better results for water curing than air curing, with deflection capacity recoveries of $65-105 \%$ for the former and $40-60 \%$ for the latter.

- Fagerlund and Hassanzadeh (2010) analyzed three types of water exposure: permanent and complete immersion, cyclic (1 week immersed in water / 1 week in lab air) and onesided capillary suction, achieving better results for complete immersion.

- Sisomphon, et al. (2013) compared four healing conditions: water immersion in tap water, water immersion in tap water with replacements every 12 hours, wet/dry cycles combining water immersion and drying, 12 hours each cycle and indoor air. Wet/dry cycles achieved the highest recoveries of flexural stiffness and flexural strength, while specimens at indoor air achieved the lowest.

- Kim, et al. (2014) studied HPSFRC with very small cracks (20 $\mu \mathrm{m})$ comparing healing after exposure in water or air. Their results show that healing in water could increase stiffness and load recovery in comparison to healing in air.

- Jiang, et al. (2015) simulated flowing water by replacing water each 12 hours, and their results showed that the cracks healed more efficiently when they were cured in still rather than flowing water.

Few authors found better healing in cycling wet/dry conditions compared to complete water immersion conditions:

- In (Yang et al., 2009; Yang et al., 2011) regimes with different moist conditions did not achieved significant healing measuring by resonant frequency in ECC specimens, while regimes of water immersion or combined cycles did, confirming the need of direct contact with water. Water immersion and cycles achieved significant recoveries higher than $80 \%$ in water immersion and cycles got the best results around $100 \%$.

- Ma, et al. (2014) also analyzed different exposures in ECC specimens to water permeability and flexural tests, obtaining that faster self-healing occurred in the healing conditions of water/air cycles for both testing methods.

Other authors have also let specimens heal under real conditions. Hannant and Keer (1983) compared tensile stress-strain curves for precracking and reloading for up to 7 months natural weathering, for cracks of very small size (7 microns), obtaining almost complete recovery of stiffness when re-tested in direct tension after 2 years healing in natural conditions and $50 \%$ of the tensile strength of the uncracked samples at the same age. Specimens healed in laboratory showed no healing. Herbert and Li (2013) stored concrete specimens in Ann Arbor in Michigan for 12 months, being exposed to a range of temperatures of -11.7 to $32.8^{\circ} \mathrm{C}$. They concluded that specimens under a natural exposure could heal; and, that cyclic loading could deteriorate the stiffness recovery.

\subsubsection{Healing: type of water}

Edvardsen $(1996 ; 1999)$, compared the effect of healing concrete specimens under different types of water: soft water $(70 \mathrm{mg} \mathrm{CaCO} / \mathrm{l})$, hard water $\left(480 \mathrm{mg} \mathrm{CaCO}_{3} / \mathrm{l}\right)$ and distilled 
water, showing that the hardness of water had only very minor influence on autogenous healing.

However, Fagerlund and Hassanzadeh (2010) analyzed three types of water (sea from the west-coasat of Sweden, brackish from south Baltic Sea, or tap water), and their results show that sea water presents better results than tap water, analyzed in terms of visual closing of cracks. They also observed that the sealing of the mouth of the crack impeded the internal healing of the crack. Palin, et al. (2015) also obtained best results in sea weater for OPC. However, for BFS had lower autogenous healing in sea-water than in fresh water, showing that that different binders may have different effectiveness depending on the type of water.

Other researchers confirm that appreciable healing occurs at synthetised waters at $\mathrm{pH}$ of 9.5 in presence of sufficient magnesium and silicon in the water, and even recovering strength (Parks et al., 2010), but that the presence of calcium did neither promote sealing nor strength regain. In that study, carbonation was not detected, but leaching of calcium was increased at higher concentrations of magnesium and silicon inside the water. In contrast, Huang and Ye (2015) compared the efficiency of self-healing in cement paste cured in saturated calcium hydroxide solution, concluding that it promoted autogenous healing. High $\mathrm{pH}$ (alkaline) has also been reported to accelerate crack healing when comparing a reference regime $(\mathrm{pH}=7)$ with an acid $(\mathrm{pH}=4)$ and an alkaline $(\mathrm{pH}=10)$ environments (Jiang et al., 2015).

\subsubsection{Healing: water temperature}

Reinhardt and Joss (2003) studied autogenous healing for high strength concrete (w/c ratio of 0.37 , cement $360 \mathrm{~kg} / \mathrm{m}^{3}$, silica fume $40 \mathrm{~kg} / \mathrm{m}^{3}$ ) for different crack widths and temperatures of water at the healing exposure, comparing 20,50 and $80^{\circ} \mathrm{C}$. Their results show a better response for smaller cracks and higher temperature of water, with the main decrease of permeability around the first 100 hours in the smaller cracks for the higher temperature, that is approximately 4 days (see Fig. 2-11). Similarly, Na et al. (2012) registered higher mechanical recoveries and lower carbonation depth after curing in water at $40^{\circ} \mathrm{C}$ than at $20^{\circ} \mathrm{C}$.
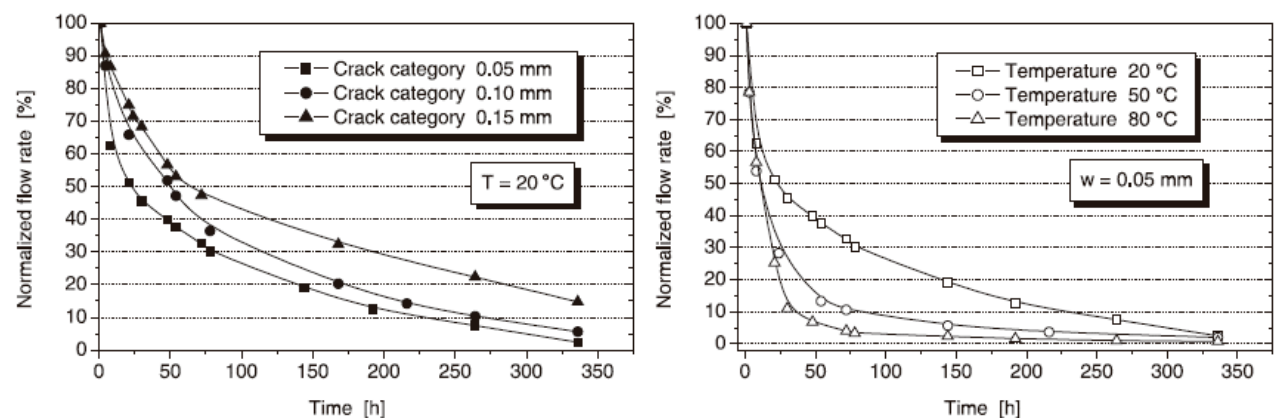

Fig. 2-11. Decrease of normalized flow rate with time for different crack widths and water temperature at healing (Reinhardt \& Joss, 2003). 


\subsubsection{Healing: time of healing}

Edvardsen (1999) showed that autogenous healing mostly took place in the first 5-7 days of water immersion (Fig. 2-12), during the surface-controlled phase. However, during the diffusion-controlled phase there is still an autogenous healing reaction. Other authors have reported the further continuation of reactions even after 20-30 days of exposure (Nishiwaki et al., 2012).

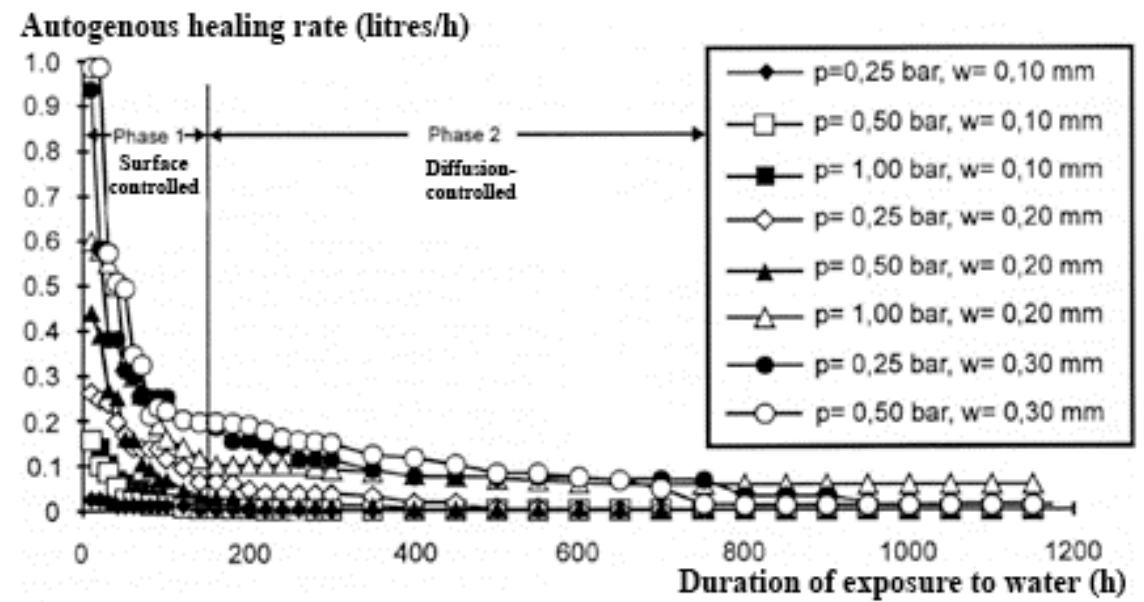

Fig. 2-12. Decrease of healing rate for different crack widths and water pressures (Edvardsen, 1999).

To sum up this section, autogenous healing is mostly produced by carbonation and continuing hydration. The highest influence comes from damage level (i.e. crack width), age of precracking and presence of water during the healing process. In contrast, composition parameters such as water/cement ratio, type of cement or type of aggregates have been reported to have inconclusive or lesser influence on autogenous healing.

\subsection{Autonomous healing}

Due to the lack of reliability of autogenous healing, several methods for achieving an engineered self-healing have been designed, which are generally named as "autonomous healing" methods.

In general, they are composed of a healing agent that reacts with a catalyst, which can be part of the concrete matrix or an additional product. The way of introducing the healing agent and the catalyst also determines different methodologies.

A classification of the different known options for these three compounds up to the date are displayed in Table 2-3. 
Self-healing concrete: efficiency evaluation and enhancement with crystalline admixtures

\begin{tabular}{ccc}
\hline Healing agent & Catalyst & Introduction method \\
\hline Cement & Water & Without encapsulation \\
Chemical agent (epoxy & Dispersed capsules \\
resins, sodium silicate, etc.) & $2^{\text {nd }}$ compound & $\begin{array}{c}\text { (microcapsules, porous } \\
\text { aggregates or fibers, etc.) } \\
\text { Biological agent (bacteria) }\end{array}$ \\
Located capsules (fragile \\
tubes or vascular systems)
\end{tabular}

Table 2-3. Classification of the known options for the three components of autonomous self-healing: healing agent, catalyst, and introduction method.

Whatever the autonomous healing method, four features are needed: 1) detection of the damage, 2) reaction of the agent with the catalyst, 3) transport of the reaction products to the damaged point, and 4) filling of the damage. That is, the healing method must detect the crack when it appears and activate the healing mechanisms, transporting the filling materials to the damaged area.

The healing agent can be introduced as an additional product to the mix process without an encapsulation or protection or can remain inside a capsule until healing activates it. The main disadvantage of not encapsulating a product is possibility of the consumption of healing potential during mixing or hydration, which will not be available in hypothetical future healing processes.

The types of encapsulation can be gathered in two groups: disperse capsules (mostly microcapsules) and located capsules (mostly glass tubes). Both methods need a physical breakage or an increase of the porosity to be activated.

The first group is thought to be added to the concrete matrix as an additional compound and is a good method for unpredictable or dispersed cracking; while the second needs to be placed in a specific location in a similar way to reinforcement bars, thus being optimal for predictable cracks.

The method of using microcapsules as carriers of the self-healing agent was developed by White, et al. (2001) to design self-healing polymers (Fig. 2-13). This idea is being extrapolated to other types of materials, such as cementitious materials. In this case, the healing agent is stored in microcapsules and the catalyzer can be in the material matrix or in different microcapsules. In this way, when a random crack appears and intersects a microcapsule, it breaks releasing its healing agent (and catalyzer if that is the case) and activating the reaction that would fill the crack by capillary action. 

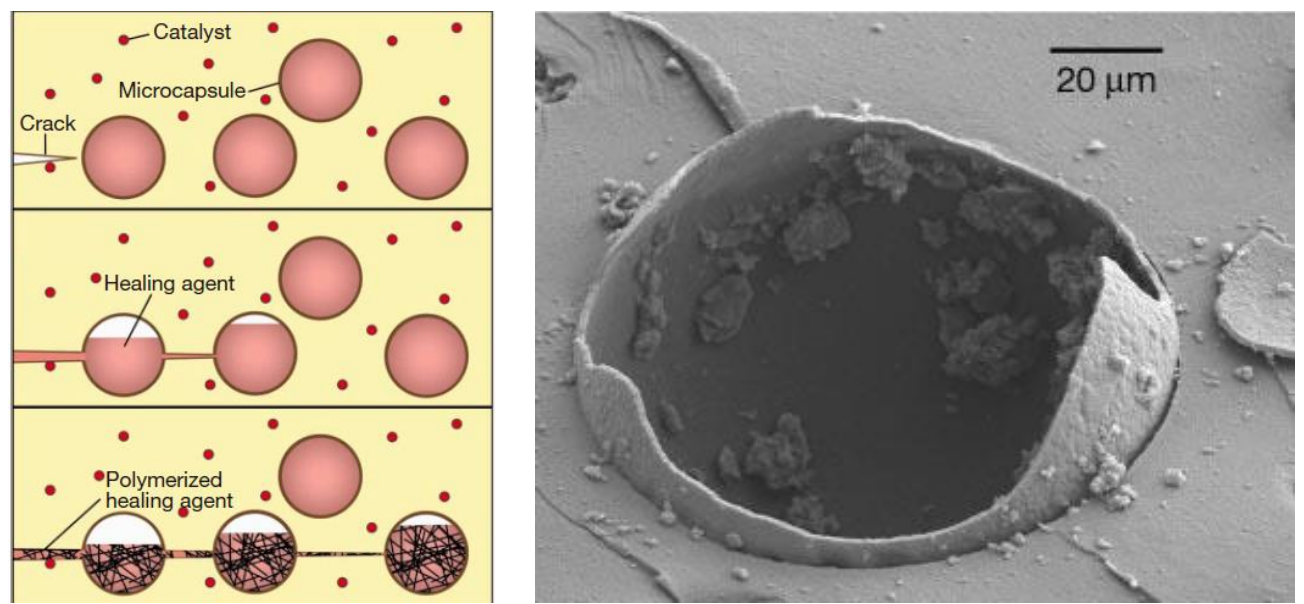

Fig. 2-13. Process of breakage of a microcapsule and release of healing agent (left) and a broken microcapsule (right) (White et al., 2001).

In the case of located capsules or tubes, they are filled with the healing agent and embedded in the cementitious matrix in fixed positions. Because of the geometry of the tubes, negative pressure forces become of great importance and can produce an inappropriate release of glue into the crack (Joseph et al., 2010). As stated by these authors, the capillary force of the crack and the gravitational force acting on the healing agent need to overcome the capillary forces that retain the agent inside the glass tube, and the negative pressure force produced by the sealed ends (Fig. 2-14). In fact, with this system, the tube slenderness, volume capacity and type of release need to be matched with the volume needed to be delivered (Dry, 1994).

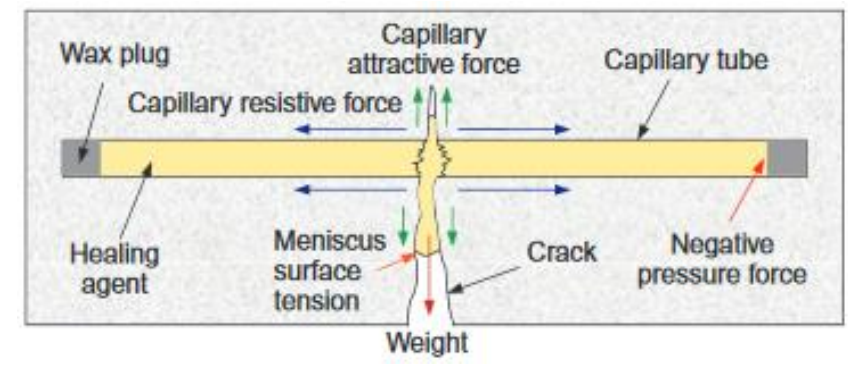

Fig. 2-14. Main forces acting on autonomic healing using located tubes (Joseph et al., 2010).

The following sections describe the different autonomous healing products proposed in the literature, organized depending on the healing agent and the introduction method inside concrete matrix. 


\subsubsection{Cement as healing agent}

Cement as healing agent is autogenous healing based on continuing hydration, having water as the catalyst, which has been explained in Section 2.2.1. The amount of unhydrated cement stored in order to react at the moment of cracking is an important parameter in order to improve the recovery of properties.

\subsubsection{Without encapsulation}

The addition of cement without encapsulation is the ordinary autogenous healing by continuing hydration.

\subsubsection{Water encapsulation}

To the knowledge of the author, there are no studies based on the encapsulation of cement. However, the encapsulation of the catalyst (water) has been of a wide interest.

Two main types of encapsulation of water have been investigated: superabsorbent polymers and natural fibers.

\section{Superabsorbent polymers (SAP)}

Superabsorbent polymers are polymers, generally made of polyacrylic acid cross-linked, also known as hydrogels or water crystals. SAPs are hydrophilic; thus, they have a high affinity with water. They have the capability of absorbing huge volumes of water and aqueous solutions, but this capability decreases dramatically when water presents dissolved ions. With pure water, SAP could easily absorb 100 grams by each gram of SAP, meaning an increase of 100 times the initial weight. In fact, some SAPs are able to absorb even around 1500 grams of water per gram of SAP, as reported in the RILEM TC 225 State of the Art Report (Friedrich, 2012). In contrast, this absorption could decrease up to 20 grams for impure water. SAP (Imperial College London, 2012). SAPs are used as shrinkage compensators in concrete (Schröfl et al., 2012). Their behavior applied to the design of selfhealing concrete is (see also Fig. 2-15):

i. SAPs are introduced during mixing of concrete

ii. Concrete suffers a crack in a random location.

iii. SAPs enter in contact with humidity and environmental water, and are filled with it.

iv. SAPs expand and fill pores and parts of the crack, blocking the entrance of external agents.

v. The slow leaching of water enhances the autogenous healing by continuing hydration or carbonation.

Then, SAPs have two possible effects related with self-healing. First, due to their expansion and filling of the crack, they can reduce the permeability of cracked concrete, and second, due to their water-pocket effect, they would promote autogenous healing. 

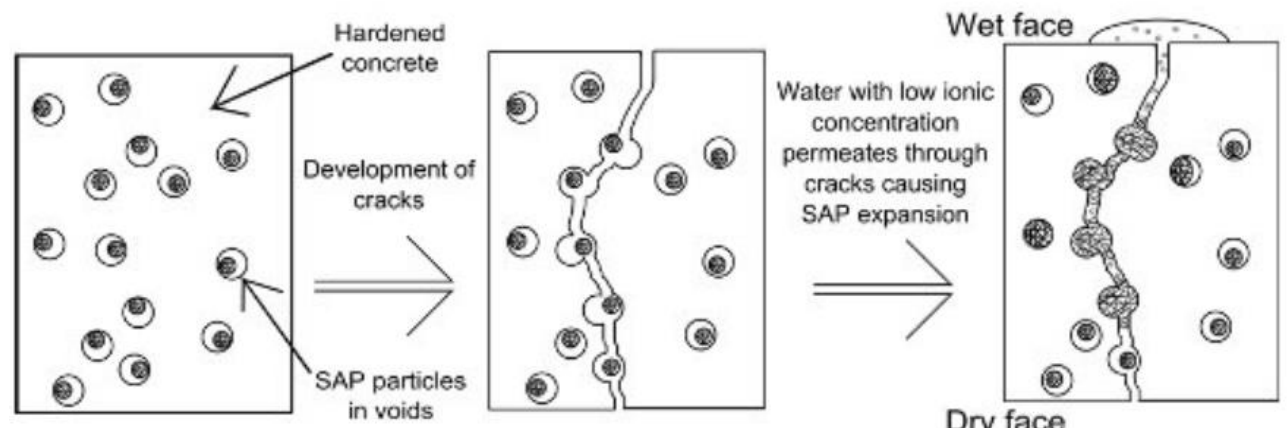

Fig. 2-15. Mechanism of superabsorbent polymers (Imperial College London, 2012).

Lee et al. (2016) showed that SAPs were able to reduce water flow of $0.3 \mathrm{~mm}$ cracks by 85 $98 \%$, and increasing SAP dosage resulted in an accelerated sealing. These authors showed that during the water permeability test, the crack exposed to the flow had swollen SAPs in form of a transparent gel which blocked the water flow (Fig. 2-16 left). However, when the concrete specimens were let drying at room temperature for 24 hours, the SAPs shrunk, and the crack was completely visible (Fig. 2-16 right).
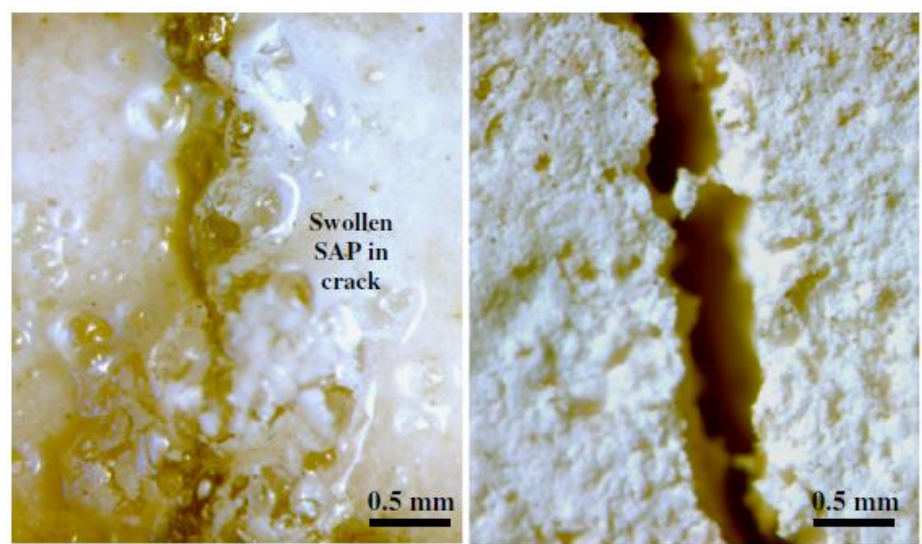

Fig. 2-16. Swollen SAP in crack (left) and crack after drying for 24 hours (Lee et al., 2016)

Regarding their effect as water-pocket effect to promote autogenous healing, several studies have been performed, mainly at Ghent University and TUDelft.

Kim and Schlangen (2011) studied the effect of SAP in self-healing. Their results showed that only specimens healing in water immersion and in wet/dry cycles achieved strength recoveries, and with better results when incorporating SAPs, proving the water-pocket effect and the need of direct contact with water when using SAPs.

Snoeck et al. $(2013 ; 2014)$ analyzed the self-healing efficiency of adding SAPs, for small cracks $(50 \mu \mathrm{m})$ healing in wet/dry cycles. Their results show that specimens with SAPs achieved higher recoveries for mechanical properties, being around $80-90 \%$ while reference 
specimens only achieved recoveries around $40-50 \%$. The healing products were mainly calcium carbonate but also hydration by-products.

High humidity exposures are not able to activate enough healing capacity of SAP (Snoeck et al., 2016). For specimens healed in wet/dry cycles the amount of healing is higher. Healing by-products were confirmed to be mostly $\mathrm{CaCO}_{3}$, with presence of $\mathrm{Ca}(\mathrm{OH})_{2}, \mathrm{CSH}$ and CASH. Even SAP being distributed randomly inside the matrix, only the region between 0-800 $\mu \mathrm{m}$ from surface was completely healed and the interior of the specimen experienced less healing (Snoeck et al., 2016).

From that same research group, Mignon et al. (2015) focused on developing pH-responsive SAPs, to control their swelling capacity. They analyzed the swelling capacity of SAPs in aqueous and in cement filtrate solutions. Their results showed optimum swelling capacity for $\mathrm{pH}$-values around 12 in aqueous solutions, however, in the acidified cement filtrate solutions one of the SAPs had almost constant swelling capacity for the different $\mathrm{pH}$ and the other had peak of swelling capacity for $\mathrm{pH}$ around 13 and only very slight increases for $\mathrm{pH}$-values between 9 and 12.5 .

The use of SAPs as self-healing promoters have two main drawbacks, the first one is the smaller swelling capacity inside the concrete matrix compared with their capacity in water, and the second is their effect on the strength of concrete, which has been reported to suffer considerable decreases with the addition of higher amounts of SAPs (Mignon et al., 2015; Lee et al., 2016). However, it should also be considered that often this decrease of strength is produced when using additional water to maintain the workability and compensate the water retention produced by SAPs.

\section{Porous vessels}

In a similar strategy, the use of porous natural fibers as water reservoirs has been studied by Toledo Filho, et al. (2005) and Snoeck, et al. (2015). The strategy of using porous fibers as an encapsulation for a self-healing agent is promising due to the multiple applications of these types of fibers in concrete, such as the reduction of shrinkage and early age cracking due to their reinforcement effect.

Toledo Filho, et al. (2005) precracked specimens by free and restrained shrinkage and were stored 40 days under water immersion at $22^{\circ} \mathrm{C}$ afterwards. Specimens with sisal fibers achieved complete healing of cracks under $0.3 \mathrm{~mm}$ while coconut fibers only achieved a reduction from $0.2 \mathrm{~mm}$ to $0.05 \mathrm{~mm}$ width, but the process was quicker in the specimens with coconut fibers.

Snoeck, et al. (2015) added flax and hemp fibers, used in the textile industry, after a chemical treatment, in ECC, which has multiple cracking behavior. After analyzing the mechanical properties and the crack closing they concluded that only cracks up to $50 \mu \mathrm{m}$ were able to heal completely.

Other porous vessels that have been studied with the purpose of promoting self-healing by the water-pocket effect are nanoclays (Qian et al., 2010). In this case, they were also added in ECC mixes, and were thought to promote further hydration even in air curing conditions.

The use of porous aggregates or fibers with compounds other than water (such as sodium silicate) is explained in Subsection 2.3.2 "Chemical powder or solution as healing agent". 


\subsubsection{Chemical powder or solution as healing agent}

The healing agent can be a different product from any of the matrix compounds. In this group, several types of healing agent can be found, such as mineral powder with chemical actives or different types of adhesives, but they should have a good compatibility with ordinary concrete matrix compounds. Those agents can be added with or without encapsulation to protect them until the moment they are required to act.

\subsubsection{Without encapsulation (self-healing admixtures)}

This section includes chemical products able to produce self-healing without encapsulation. These products are generally mineral admixtures designed to be used in lower dosages, in general under $5 \%$ by cement weight. These products include: crystalline admixtures, calcium sulfoaluminate expansive admixtures and combination of several mineral agents. The disadvantage of these products is the possibility of consumption of the healing capability before a crack occurrence, as they are not encapsulated. They are thought to store a certain capability to heal older age cracks, but their performance is still being studied.

\section{Crystalline Admixtures (CA)}

Crystalline admixtures (CA) are classified as a special type of permeability-reducing admixtures (PRAs) (ACI Committee 212 (2010)). ACI-212 differentiates between PRAs that reduce permeability under non-hydrostatic conditions (PRAN) and those that are also capable under hydrostatic pressures (PRAH). CA are included in the latter, while typical water-repellent or hydrophobic products fall in the former category.

In general, CA are products formed by active chemicals contained in cement and sand, with highly hydrophilic behavior. They react in the presence of water, forming water insoluble pore/crack blocking precipitates that increase the density of Calcium Silicate Hydrate $(\mathrm{C}-\mathrm{S}$ $\mathrm{H})$ and resistance to water penetration.

When comparing the other types of PRAs with CA to improve permeability (see Fig. 2-17), CA showed to be more effective than colloidal silica and pore-blocking admixtures (ACI Committee 212, 2010). CA are efficient in more than blocking pores, however, and they also possess the capability of withstanding hydrostatic conditions and the ability of sealing hairline cracks when activated by moisture the ACI Committee 212 (2010).
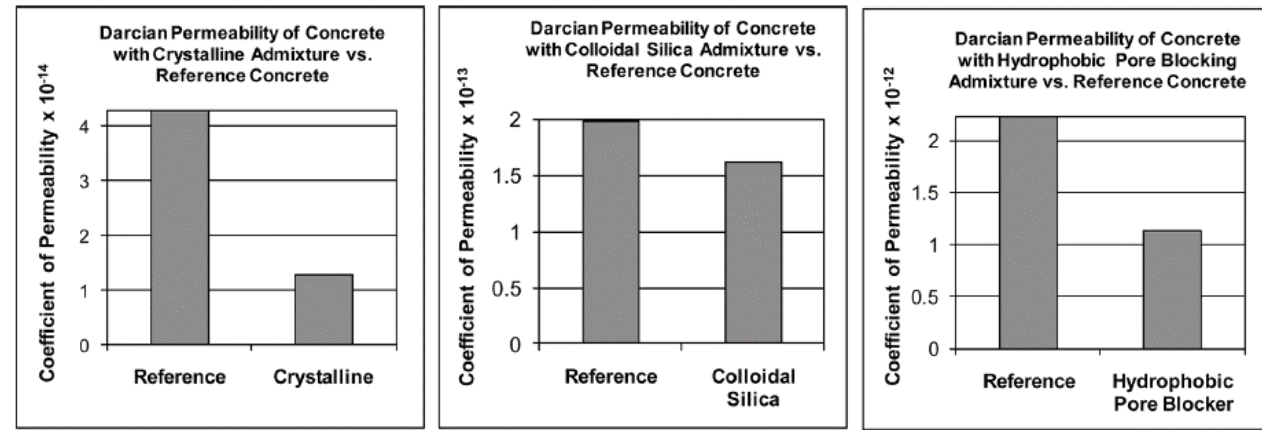

Fig. 2-17. Comparison of the permeability reduction achieved by different permeability-reducing admixtures (ACI Committee 212, 2010). 
A wide range of materials is included as permeability reducing admixtures, and that could also occur with the generic name of "crystalline admixtures". Moreover, most commercial products contain proprietary constituents and their formulations are kept confidential. The fact that some publications report presence of different oxide compounds in CA, such as sulfur trioxide (Sisomphon et al., 2013) or sodium oxide (Jaroenratanapirom \& Sahamitmongkol, 2011), reinforces this point and may indicate different behaviors under the global name of "crystalline admixtures".

As a product of their reaction, according to the cited ACI report, CA reacts with tricalcium silicate (see equation 2.4) to form modified C-S-H, depending on the crystalline promoter, and a precipitate formed from calcium and water molecules. However, other studies indicate that CA react with portlandite instead (Sisomphon et al., 2013; Ferrara et al., 2016).

$$
3 \mathrm{CaO}-\mathrm{SiO}_{2}+\boldsymbol{M}_{x} \boldsymbol{R}_{\boldsymbol{x}}+\mathrm{H}_{2} \mathrm{O} \rightarrow \mathrm{Ca}_{x} \mathrm{Si}_{x} \mathrm{O}_{x} \mathrm{R}-\left(\mathrm{H}_{2} \mathrm{O}\right)_{x}+\mathrm{M}_{x} \mathrm{CaR}_{x}-\left(\mathrm{H}_{2} \mathrm{O}\right)_{x}
$$

Tricalcium silicate + crystalline promoter + water $\rightarrow$ modified $C S H+$ pore-blocking precipitate

Weng and Cheng studied the mechanical properties of concrete with CA (2014), and their results showed that $\mathrm{CA}$ improved the compressive and splitting tensile strengths when using contents of 3,5 and 7\% of the cement content, subjected to moisture curing. (Silva et al., 2017) report a successful case study of an anti-flotation slab of reinforced concrete, where CA were used to ensure water tightness.

Regarding the self-healing improvements achieved by means of crack closing, water permeability or strength recovery, the following studies have been published.

The studies from Jaroenratanapirom and Sahamitmongkol (2011) compared the visual closure for different additions, including crystalline admixtures. CA showed their best results for visual closure of cracks for small and early age cracks ( $<0.1 \mathrm{~mm}$ and 3 days) but they were ineffective for larger cracks (around $0.3 \mathrm{~mm}$ ) in comparison to OPC mortars.

Sisomphon, et al. (2012), reported as a limit of the self-healing capability of crystalline admixture cracks widths of 150 microns (for 30 days of water immersion). Those authors obtained for the control mortar, slight reduction of water passing rate can be observed in the early period, while those mortars with CA showed rapid reduction of water passing ability during the first 5 days. Regarding the recovery of mechanical properties of strain-hardening cementitious composites containing of CA ( $1.5 \%$ by weight of cementitious materials), the admixtures hardly produced any benefit when compared with control specimens (Sisomphon et al., 2013). However, their results showed good efficiency when added in combination with an expansive agent.

Ferrara et al. (2014) studied the effect of CA on strength recovery in normal strength concrete specimens, containing CA at a dosage of $1 \%$ by the weight of cement, achieving an improvement of $14 \%$ in the self-healing properties of concrete by the addition of CA. In both cases, specimens healed underwater. They stored the precracked specimens in wet/dry cycles simulating real Italian climate for 4 weeks. The initial precracks were 130 and 270 $\mu \mathrm{m}$. Reference specimens were healed up to $70 \%$ while concrete with CA achieved recoveries around $80 \%$ of crack width, thus the addition of CA produced an improvement of $14 \%$ in self-healing. The improvement can be significantly better in High Performance 
Fiber-Reinforced Composites (Ferrara et al., 2016). Using CA in lime mortars had similar responses, in terms of the recovery of compressive strength (De Nardi et al., 2016).

This work studies the behavior of crystalline admixtures without encapsulation for the selfhealing of concrete specimens.

\section{Expansive Admixtures}

These admixtures are used as shrinkage compensators and are usually composed of calcium sulfoaluminates (CSA). They have been considered potential self-healing agents due to their expansive reaction, which could fill cracks.

Jaroenratanapirom and Sahamitmongkol (2011) added CSA in a 10\% by the weight of total binder, obtaining a positive effect on visual closure for early age mortars and cracks of size 0.1-0.3 mm, when compared to other mineral additions and OPC, but CSA did not stand out in other situations studies.

Sisomphon, et al. $(2012 ; 2013)$ compared the effect of substituting $10 \%$ of the cement content by two CSA-based expansive agents, analyzing visual closing, water permeability and the recovery of flexural stiffness and flexural strength. Both CSA improved healing in terms of water permeability and crack closing. The CSA with lower amount of $\mathrm{CaO}$ and higher $\mathrm{Al}_{2} \mathrm{O}_{3}$ and $\mathrm{SO}_{3}$ had better results, especially during the first 14 days. In the case of mechanical properties only slight improvements were noticed.

\section{Other minerals and optimization of combination of minerals}

Sisomphon, et al. $(2012 ; 2013)$ achieved the best results when combining CSA with CA for all the methods. Other authors have combined different mineral compounds to achieve a better healing performance.

Ahn and Kishi, (2010) designed a self-healing agent combining three terms: the expansion term given by expansive admixtures (hauyne, anhydrite and free lime), the swelling term given by geopolymers (silica and alumina) and the precipitated term given by chemical agents (including several carbonates: $\mathrm{NaHCO}_{3}, \mathrm{Na}_{2} \mathrm{CO}_{3}$ y $\mathrm{Li}_{2} \mathrm{CO}_{3}$ ). They concluded that the geomaterials were useful to achieve self-healing concrete, but the velocity for rapid water proof effect of water leakage needed to be improved. The addition of the expansive agents and chemical additives stabilized and quickened the healing process. With the optimal combination, concrete heals notably $0.15 \mathrm{~mm}$ cracks in 3 days and $0.2 \mathrm{~mm}$ cracks in 7 days with a complete healing after healing for 28 days under water immersion. The healing products formed by this agent were mostly fibrous $\mathrm{C}-\mathrm{A}-\mathrm{H}$ phases (hydrogarnet) and calcite. Fibrous phases were formed by the chemical agents and bridged cracks.

Jiang, et al. (2015) also studied the effect of several minerals and their combination on selfhealing, including: silica-based materials, chemical expansive agents, swelling minerals and crystalline components on self-healing. Their study concludes that when adding a single mineral, the expansive admixtures have the most effective response, due to their fast crystal growing. On the contrary, silica-based and crystallization reactions take more time, and, in the latter, the ions are potentially drained away by water. Combining the three components gives the best crack healing response.

Qureshi and Al-Tabbaa (2016) analyzed the improvement on healing produced by adding reactive magnesium oxide of two different reactive grades. They obtained greater self- 
healing performance of samples with $\mathrm{MgO}$ compared to OPC mixes (and greater when increasing the $\mathrm{MgO}$ content), with cracks up to $500 \mu \mathrm{m}$ sealed after 28 days. Improvements were also registered in durability properties, by sorptivity and gas permeability analysis, and in terms of strength recovery. The expansion of samples curing in water has been suggested to accelerate healing by approaching the crack tips. The healing byproducts formed in the crack included brucite and different phases of hydromagnesites, hydrotelcite and even magnesian calcite. (Sherir et al., 2017) also confirmed the potential of $\mathrm{MgO}$ in enhancing strength recovery, healing the micro-cracks due to their expansive behavior.

Quicklime has also been reported to led to good results, while bentonite is less reactive than $\mathrm{MgO}$ and $\mathrm{CaO}$ and with hydration products of less density (Qureshi et al., 2016).

\subsubsection{Located encapsulation}

A different strategy is the introduction of fragile capsules in located positions. These capsules would be activated by cracking in specific locations.

Dry in the mid-90s, proposed a design that needed external action, in which methyl methacrylate was used as healing agent, which polymerizes by the action of heat, and then fills cracks, reducing permeability (Dry, 1994). But that research also shows a passive design that did not require external action, using a three-compound system, with methyl methacrylate and one of the initiator in one glass tube and the other initiator inside the contiguous glass tube. When cracks appeared, glass tubes were broken mechanically, releasing the two products, which reacted and filled the cracks. In only one hour, the products set and permit a recovery of strength (Dry \& McMillan, 1996). In later studies, the author experimented these systems in true scale models of a bridge deck (Fig. 2-18), where the tubes broke due to transverse shrinkage strain and shear cracks. The experimental results confirmed the feasibility of this system to heal cracks autonomously (Dry, 2000).

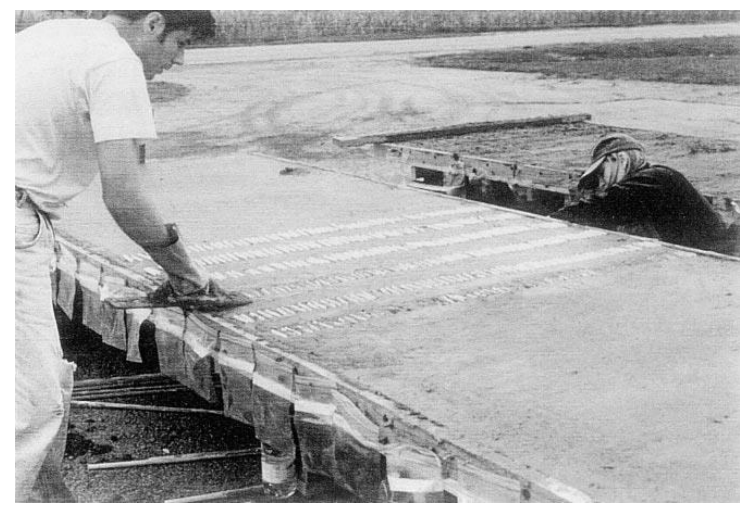

Fig. 2-18. Glass tubes in a bridge deck (Dry, 2000).

Later, a similar system with glass tubes containing fast air curing superglue of low viscosity has been combined with strain-hardening fiber-reinforced concrete in order to verify its behavior under cyclic loading (Li et al., 1998). The elastic modulus recovered its original value in a repeated loading, supporting this concept for achieving self-healing concrete. 
Joseph, et al. (2010) tested to two load cycles reinforced mortar beams containing glass tubes filled with different adhesives. Their study shows that using cyanoacrylate the release of the agent was easier, and achieved stiffness recoveries, new load peaks and new crack paths. Their study also shows that for some healing agents the encapsulated system did not allow the adhesive to flow out due to the negative pressure inside the tube. In fact, when using the cyanoacrylate, even though approximately $10 \mathrm{ml}$ were available inside the tube, only around $0.1-0.3 \mathrm{ml}$ was estimated as the quantity flowing into the crack.

Other authors tried similar designs, Sun, et al. (2011) embedded ethyl cyanoacrylate in hollow fibers of diameter of $4 \mathrm{~mm}$ and $20 \mathrm{~cm}$ length and studied cracks of different widths, but only achieved strength recoveries up to 20\%. Pang et al. (2011) tested glass tubes with an adhesive in order to design a self-healing beam, a self-healing column and a self-healing slab. The tubes were fixed by tying them to the reinforcement bars of the structure. The results showed recoveries of $84 \%$ of flexural strength in the bream, $70 \%$ in the column (which was lower due to the different direction of the flow) and $99 \%$ of strength recovery for the slab, which was tested to multiple impacts.

Several studies on this topic have been made in Ghent University. Tittelboom, et al. (2011) compared the behavior of glass and ceramic tubes with a two-compound system with methyl methacrylate. The precracked up to $0.3 \mathrm{~mm}$ mortar cylinders, which contained the tubes inside their matrix. When the healing agents reacted and filled cracks, the permeability was similar to that of virgin specimens. Their results showed a better behavior for ceramic tubes in comparison to glass tubes.

In another study they used polyurethane as the healing agent, and obtained that mortar specimens were able to recover $50 \%$ of the original strength and stiffness after self-healing (Van Tittelboom et al., 2011). After the healing process, they evaluated the cross-sections of the specimens and found that for all series the crack faces were partly covered with polyurethane foam. Their study compared series with manual injection of the healing agent with pure autonomous healing systems. The first series had complete covering of the crack length. For the autonomous healing systems, besides the capillary forces, the agent was able to move out of the tube and against gravitation, however, the covered area was smaller for compared to those with manual injection, with the agent concentrating around the tube, especially when using $2 \mathrm{~mm}$ glass tubes compared to $3 \mathrm{~mm}$ tubes.

Later they embedded ceramic tubes, with inner diameter of $3 \mathrm{~mm}$, with a polyurethane prepolymer and a catalyzer in mortar prisms, which were then embedded in concrete beams. In this way, mortar prisms were a capsule protecting the self-healing encapsulated agent (Van Tittelboom et al., 2012). The load-crack width graphs showed the recovery of mechanical properties that were achieved due to the healing mechanism. Reference specimens did not recover stiffness or load, while self-healed specimens recovered both, with an almost $100 \%$ of recovery (see Fig. 2-19). 

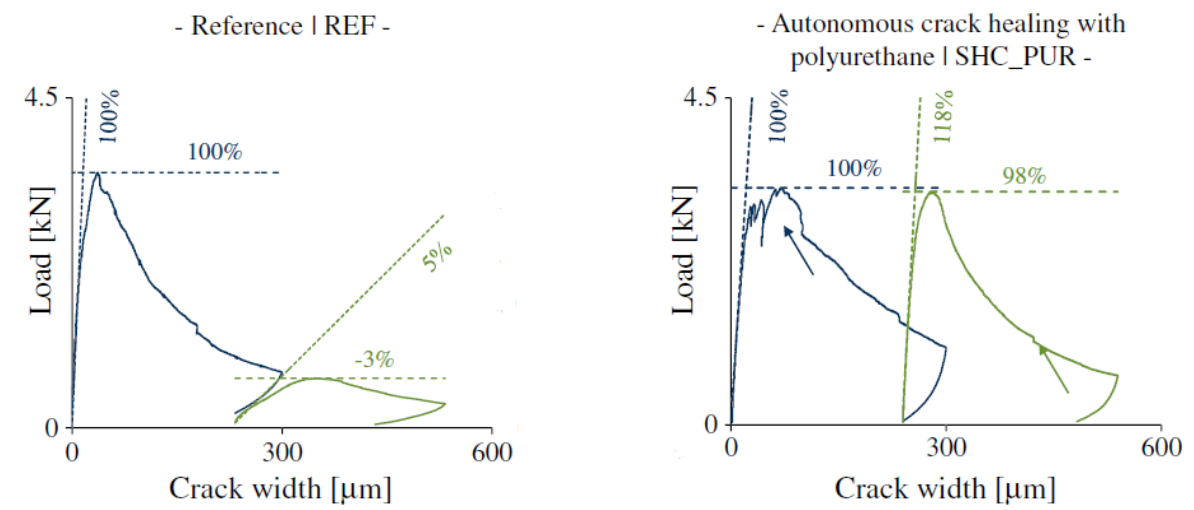

Fig. 2-19. Load-crack width curves for virgin and healed specimens (Van Tittelboom et al., 2012).

Van Tittelboom, et al. (2015) compared in concrete specimens $(100 \mathrm{~mm} \times 100 \mathrm{~mm} \times 650$ $\mathrm{mm}$ ) reinforced with steel fibres (RC-80/60-BP) and with two steel bars, the resistance of tubes as encapsulation materials, containing polyurethane as healing agent, analyzing their survivability if added into concrete mix (protected) or attached to the reinforcement bars. Their results showed that mixing glass or ceramic tubes in the concrete mix, protected by a cement paste bar is the least efficient method since the tubes do not survive the mixing process in a concrete mixer. However, both glass and ceramic capsules, attached to the reinforcement, survived the casting process without protection.

Later, they increased the testing scale to concrete beams of $150 \mathrm{~mm} \times 250 \mathrm{~mm} \times 3000 \mathrm{~mm}$, again using an expansive polyurethane-based healing agent, and analyzed the recovery by non-destructive methods (Karaiskos et al., 2016). The same group also tested the effectiveness of products commercially used as crack injection, encapsulated in tubes against moving cracks (Feiteira et al., 2016). Their study highlights again the importance of the viscosity of the agent, and the regain of mechanical stiffness was limited to a maximum of $30 \%$ showing that healing could be disrupted for the widening of cracks due to fatigue.

Kanellopoulos, et al. (2015) encapsulated three liquid agents (sodium silicate, colloidal silica and tetraethyl orthosilicate, Fig. 2-20 left) and one powder agent (magnesium oxide), in tubes. Their results showed that all the compounds had potential as self-healing agents, but colloidal silica and sodium silicate were more efficient. All the agents needed the presence of water, being not enough with high environmental humidity. Later, the same authors encapsulated water and expansive powder minerals (magnesium oxide, bentonite and quicklime) within a concentric glass capsule system, obtaining a system able to heal large cracks $(\sim 400 \mu \mathrm{m})$ effectively (Qureshi et al., 2016). The capsules consisted on glass macro-capsules with the expansive minerals in the outer capsule and water in the inner capsule.

\subsubsection{Dispersed encapsulation}

The introduction of dispersed capsules is a better approach to deal with random and disperse cracking than located encapsulation. The two main methods for the introduction of dispersed capsules with chemical healing agents are: microcapsules and porous vessels. 


\section{Microcapsules}

Three main families of healing agent have been used stored in microcapsules: adhesives, epoxy resins, and sodium silicates, being the latter the most frequently used in the literature.

Yang, et al. (2011) tested mortar with microcapsules $(5-40 \mu \mathrm{m})$ with oil core and silica gel shell, using methylmethacrylate monomer as healing agent and tri-ethylborane as catalyst. The microcapsules were added in a $1.5 \%$ by the weight of cement. The self-healing process was verified by permeability measurements and mechanically using fatigue tests, demonstrating that self-healing mortar achieved lower permeability coefficient than control specimens. When comparing the fatigue results, specimens with microcapsules resisted more cycles but at a lower load.

Zhang, et al. (2013) used urea-formaldehyde resin microcapsules with a dissolved epoxy resin. They achieved higher healing results when increasing the content of microcapsules for permeability and strength. The healing percentage increased with the size of microcapsules.

Regarding the use of sodium silicate as the encapsulated material, Pelletier, et al. (2011) experimented with polyurethane microcapsules $(40-800 \mu \mathrm{m}$ size) containing a sodium silicate solution. This healing agent would react with calcium hydroxide of concrete matrix forming C-S-H gels that would heal cracks. The final flexural load in the self-healing specimens was $26 \%$ of the original value, and only up to $14 \%$ in reference specimens.

Dong, et al. (2013) studied custom-designed prismatic fragile polymeric microcapsules with sodium silicate powder, added in ECC in the volume fractions of $0,3.45 \%, 6.9 \%$ and $10.35 \%$. They analyzed the recovery of strength and stiffness, in specimens cured in air and cured in a $100 \%$ RH curing room for 3 days. Their results show that specimens with microcapsules cured at high humidity conditions recovered more stiffness, especially for contents of $6.9 \%$ of volume of the mixture, but with high dispersion of the results.

Pérez et al. (2013) studied in cement paste samples the self-healing performance of silica microcapsules containing an epoxy sealing compound (CAP) and nanosilica particles functionalized with amine groups (NS). In that first study, the authors measured the pozzolanic activity and the mechanical strength, achieving a compensation of the loss of strength produced by the addition of the microcapsules by their pozzolanic activity. Later, they assessed the self-healing performance by means of capillary absorption, by using the sorptivity index (Perez et al., 2015), and afterwards in ultra-high performance concrete with $\mathrm{CAP}$, showing that the absorption rate was smaller in the mixes with the microcapsules (García-Calvo et al., 2017; Pérez et al., 2017).

At University of Cambridge, several microencapsulation techniques have been proposed. They added microencapsulated sodium silicate in both liquid and solid form to cement specimens (Giannaros et al., 2016), analyzing the effect on the rheological and mechanical properties of cement. Their results showed that adding the microcapsules decreased compressive strength, but improved crack-sealing measured through the sorptivity index. After 7 days of healing, the addition of $4 \%$ microcapsules reduced sorptivity up to $45 \%$ compared reference specimens without microcapsules. Fig. 2-20 right shows a broken microcapsule. They also tested at different volume fractions their effect on mortars, showing that microcapsules decreased compressive strength, but the improvement in self- 
healing potential was higher, with crack mouth healing areas of almost $100 \%$ (Kanellopoulos et al., 2016)
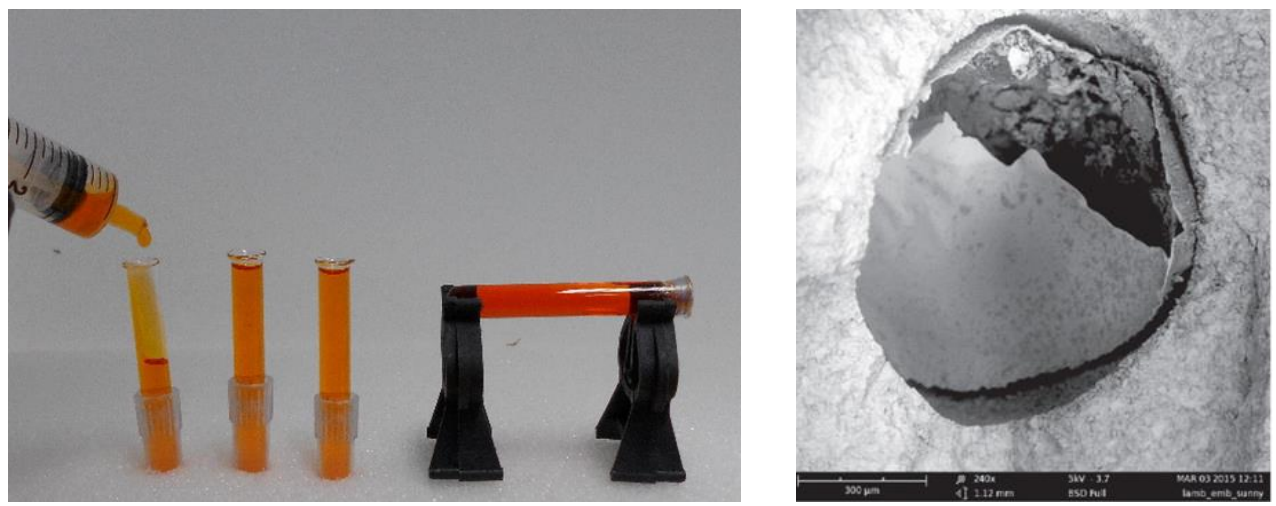

Fig. 2-20. Left: Filling glass capsules with the healing material (Kanellopoulos et al., 2015), and right: Scanning electron microscope image of a broken microcapsule (Giannaros et al., 2016).

Later they produced polymeric microcapsules (sized 300-700 $\mu \mathrm{m}$ ) for self-healing concrete, using sodium silicate as the healing agent and gelatin-acacia gum crosslinked coacervate as shell material (Kanellopoulos et al., 2017). The shell material was designed to be soft when hydrated and stiff/glassy when dried, and it showed to be able to survive at high alkaline conditions and to be stable at temperatures up to $190^{\circ} \mathrm{C}$. Microcapsules survived mixing process with cement, broke at crack formation and released the sodium silicate solution.

\section{Porous vessels}

In a similar concept to microcapsules, porous lightweight aggregates have been also impregnated with healing agents in order to counteract dispersed and random damage. Sisomphon, et al. (2011) used 2-4 mm sized porous clay aggregates impregnated with sodium fluorophosphate. The aggregates were covered with a layer of cement paste. The damaging trigger was the carbonation front, which increased the porosity of the protecting cement layer allowing the release of the healing agent. The healing products were similar to apatite and were able to seal small pores, which was measured by the capillary absorption.

Alghamri, et al. (2016) also introduced into concrete lightweight aggregates (size 4-8 mm) impregnated with a sodium silicate solution and coated with a polyvinyl alcohol (PVA) applied by spray. This coating prevented the leakage of the solution before cracking. Specimens containing the impregnated LWA experienced an $80 \%$ of recovery of the precracking strength, and reduced sorptivity, for cracks up to $300 \mu \mathrm{m}$, after 28 days of healing in water. The byproducts of the healing reaction were characterized as CSH gels.

Another strategy to achieve dispersed capsules is the use of porous fibers or natural fibers. This was already suggested by Fernández Cánovas, et al. (1992) with the use of impregnated sisal fibers in concrete. The healing agents were colophony, tannin or other natural agents, and specimens were stored under water to let the agents act, achieving permeability decreases and durability improvements. Nevertheless, this method needs further development in order to avoid the degradation of natural fibers and obtaining an effective releasing of the agents. 


\subsubsection{Bacteria as healing agent}

One of the newest healing agents to achieve self-healing concrete is bacteria, in a type of concrete usually named bacterial concrete or bioconcrete. Not every type of bacteria is suitable for this purpose. The main characteristics of these microorganisms should be the endurance to alkaline exposures and the capability of precipitating crystals, which is frequently calcium carbonate (Schlegel, 2003). In order to survive to aggressive exposures, it is recommended the use of bacteria that are able to adopt an endospore form, a highstrength survival form intrinsic to some species. Bacteria in endospore form are dormant and when the exposure is favorable to their development, that is, contains nutrients and water, bacteria wake up. Bacteria are able to live decades, even centuries in the endospore form (Schlangen et al., 2010). Moreover, these bacterial strains have also to be oxygen tolerant, since oxygen can enter in the concrete matrix through diffusion or through the cracks (Jonkers et al., 2010). Some of the species used in the literature for this purpose are sporosarcina pasteurii, bacillus sphaericus, bacillus cohnii and bacillus subtilis.

Castanier et al. (1999) summarize the different metabolic pathways that can produce the precipitation of calcium carbonate (carbonatogenesis), which belong to the nitrogen cycle (ammonification of amino-acids, degradation of urea and uric acid, dissimilatory reduction of nitrates) and to the sulphur cycle (dissimilatory reduction of sulphates). These processes have been reported to happen in marine water, freshwater, and soils. Concerning selfhealing, three types of reactions have been investigated to achieve self-healing: urea decomposition, oxidation of organic acids, or nitrate reduction (De Belie, 2016).

Only few studies have been performed regarding the precipitation of silica instead of calcium carbonate (Ghosh et al., 2009), and because of that, this section will focus on the systems with precipitation of calcium carbonate.

\section{Urea decomposition}

Urea hydrolysis in calcium-rich environments makes bacteria produce calcium carbonate (Siddique \& Chahal, 2011). This happens by the urease enzyme production, which catalyzes urea to carbon dioxide $\left(\mathrm{CO}_{2}\right)$ and ammonium $\left(\mathrm{NH}_{4}\right)$, thus increasing $\mathrm{pH}$ and stimulating the carbonate precipitation. The reaction process is shown in equations (2.5) to (2.9), taken from (Van Tittelboom et al., 2010):

$$
\begin{gathered}
\mathrm{CO}\left(\mathrm{NH}_{2}\right)_{2}+\mathrm{H}_{2} \mathrm{O} \rightarrow \mathrm{NH}_{2} \mathrm{COOH}+\mathrm{NH}_{3} \\
\mathrm{NH}_{2} \mathrm{COOH}+\mathrm{H}_{2} \mathrm{O} \rightarrow \mathrm{NH}_{3}+\mathrm{H}_{2} \mathrm{CO}_{3} \\
\mathrm{H}_{2} \mathrm{CO}_{3} \rightleftarrows \mathrm{HCO}_{3}^{-}+\mathrm{H}^{+} \\
2 \mathrm{NH}_{3}+2 \mathrm{H}_{2} \mathrm{O} \rightleftarrows 2 \mathrm{NH}_{4}^{+}+2 \mathrm{OH}^{-} \\
\mathrm{HCO}_{3}^{-}+\mathrm{H}^{+}+2 \mathrm{NH}_{4}^{+}+2 \mathrm{OH}^{-} \rightleftarrows \mathrm{CO}_{3}^{2-}+2 \mathrm{NH}_{4}^{+}+2 \mathrm{H}_{2} \mathrm{O}
\end{gathered}
$$

In this process, cellular walls are negative charged, attracting cations (such as $\mathrm{Ca}^{2+}$ ), that would react with the carbonate ions $\left(\mathrm{CO}_{3}{ }^{2-}\right)$ forming calcium carbonate. These points also act as precipitation nuclei. This urea-based process is a high-efficience process, as it allows the precipitation of high amounts of $\mathrm{CaCO}_{3}$ in short times (Whiffin, 2004). The main disavantage of this method is the decrease of $\mathrm{pH}$ (increasing corrosion problems), which is due to the ammonia production (Jonkers et al., 2010). This is the main reason for the search of different bacterial reactions that precipitate suitable healing products. 


\section{Oxidation of organic acids}

Jonkers (2011) used bacteria of different metabolism and calcium lactate as nutrient. In that design, not only bacteria produce calcium carbonate, they also produced carbon dioxide, which would be trapped inside concrete and available to produce even more calcium carbonates, thus being more efficient than the ordinary carbonation reaction of concrete. The reaction that took place in that calcium carbonate precipitation due to bacteria is shown in equation (2.10):

$$
\mathrm{Ca}\left(\mathrm{C}_{3} \mathrm{H}_{5} \mathrm{O}_{2}\right)_{2}+7 \mathrm{O}_{2} \rightarrow \mathrm{CaCO}_{3}+5 \mathrm{CO}_{2}+5 \mathrm{H}_{2} \mathrm{O}
$$

Jonkers also suggested that the higher consumption of oxygen by these bacteria reduces the possible corrosion of reinforcement bars.

The first studies about self-healing bacterial concrete were with bacteria not encapsulated, but later the need of further life and space motivated the research of encapsulation methods.

\subsubsection{Without encapsulation}

Jonkers and Schlangen (2007) published their design for achieving self-healing concrete with bacillus cohnii (Fig. 2-21 left), taking advantage of their capability of endospore formation. The bacterial solution was added to concrete in the mixing water. They activated the dormant bacteria curing the specimens with a solution containing the nutrients of the bacteria, which in this case was sodium citrate. Their results showed a $10 \%$ decrease of compressive strength of mortar, but bacteria were able to precipitate calcite crystals of 100 $\mu \mathrm{m}$ size (see (Fig. 2-21 right), thus being potential crack sealers (Jonkers \& Schlangen, 2008). Later they improved the design, incorporating the nutrients in the mixing water and concluded that bacteria could live only around 4 months due to the continuing decrease of porosity of concrete matrix (produced by continuing hydration), thus limiting the space for bacteria to live (Jonkers et al., 2010; 2011).

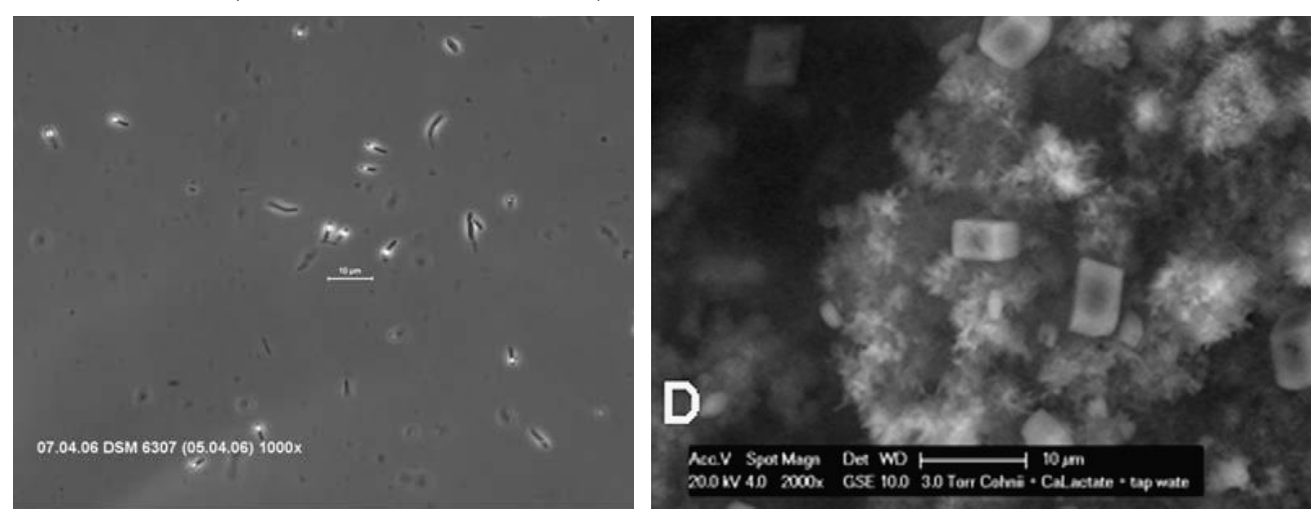

Fig. 2-21. Left: Endospore formation from bacillus cohnii (Jonkers \& Schlangen, 2007)) and right: final calcite precipitates (Jonkers et al., 2010).

\subsubsection{Located encapsulation}

In a similar way to the introduction of chemicals inside fragile glass tubes, bacteria can be immobilized and encapsulated in tubes. Wang, et al. (2012) introduced bacteria with the 
nutrients in sol-gel and in polyurethane. They compared the results in mortars with the two types of encapsulates with the same specimens but with dead bacteria, in order to isolate the effect due to the microbiological activity. According to their results, bacteria in sol-gel precipitated more calcium carbonate, while specimens with polyurethane tubes achieved the higher strength recoveries (50-80\%).

\subsubsection{Dispersed encapsulation}

In order to encapsulate bacteria in a dispersed method, Jonkers (2011) used lightweight aggregates impregnated with the bacterial solution and nutrients. In this way, bacteria are protected and remain available more years, being hypothesized that more than 50 years, which is a usual value of service life for concrete structures. Jonkers used as reference specimens mortars with bacteria but without nutrients, in order to distinguish the effect due to the metabolism of bacteria. All specimens were precracked at the age of 56 days and cured in water for 24 hours. After 6 months, bacteria were still alive and self-healing was increased. Later, Wiktor and Jonkers (2011) quantified the healing effects in prismatic mortar specimens with reinforcement. They generated crack widths between 0.05 and $1 \mathrm{~mm}$ that were cured under water immersion in order to activate the healing processes. In this case, they used bacteria similar to bacillus alkalinitrilicus. Their results showed that for 20 days of healing there was not any difference between control and bacterial specimens, but at 40, 70 and 100 days of exposure bacterial concrete had better healing performance.

Wang, et al. (2012) immobilized bacillus sphaericus bacteria, urea and yeast in diatomaceous earth. This bacterial earth was added to mortar specimens, in different dosages. The method proved to be useful in order to protect bacteria, producing less aggressive $\mathrm{pH}$ surroundings for the microorganisms. They achieved complete healing of cracks between 0.15 and 0.17 , but with different effectiveness depending on the bacterial concentration and the healing exposure. They achieved higher reductions of the capillary water uptake in bacterial specimens, being reduced 50-70\% from the reference specimens. The healing products were calcium carbonate with urea and calcium nitrate crystals.

Other reported methods of encapsulating bacteria are melamine formaldehyde based microcapsules (Wang et al., 2014), and superabsorbent polymers (Wang et al., 2015).

Autonomous healing of concrete by using bacteria is a promising method, but still needs further research. This type of healing has been generally studied room temperature and freshwater, however, all these bacterial precipitation processes explained will be greatly affected by the environmental conditions: humidity, temperature, $\mathrm{pH}$, etc. Recently, Palin et al. (2016) also showed in a preliminary study its potential for low-temperature marine environment, but further research is needed to discern the optimal environmental conditions for the different bacterial strains and encapsulation methods. 


\subsection{Experimental tests to evaluate self-healing in concrete}

The evaluation of the self-healing properties of concrete, as any other property, requires reliable and reproducible test methods for its evaluation. Several methods have been proposed in the last years, and several efforts have been made towards the standardization, in the context of RILEM committees (TC 221-SHC active from 2005 to 2013 and TC-SHE, started in 2016), the HealCON project, finished in 2016 and the COST Action SARCOS (started in 2016). However, any standard has been released yet.

The general methodology used to evaluate the effects of self-healing consists of five stages (Fig. 2-22): first, production of the specimens; second, creation of controlled damage in the specimens; third, measurement of certain properties, such as permeability or crack geometrical parameters; fourth, simulation of the conditions or environmental exposure needed to achieve better healing results and, fifth, evaluation of the recovery of the same property measured in the third stage, in order to detect the improvements due to the healing process.

The features of each step condition the needs for rest of stages. In the case of the study of mechanical regain evaluated with three or four point bending or tensile tests, the damaging stage is a precracking test, generally simultaneous to the study of initial properties. However, in the case of mechanical regain by compressive strength other precracking or damaging processes have been used widely.

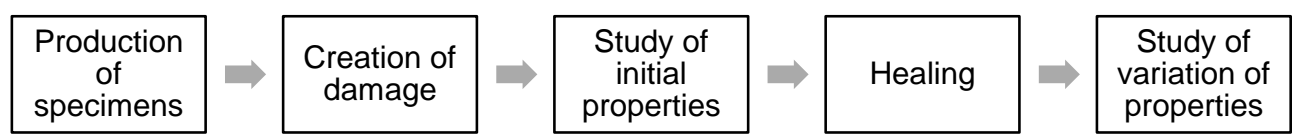

Fig. 2-22. General methodology procedure.

Different methodologies have been used to evaluate the improvements of properties produced by self-healing, and they can be classified depending on the type of property of interest: filling of cracks, transport properties, mechanical properties, non-destructive tests, and analysis of the healing by-products. Even though in many cases the tests are already been used to evaluate other properties of concrete, these methods will have particularities when used for the self-healing evaluation.

This section reviews the methodologies used in the literature for the evaluation of selfhealing up to 2017. Some methods explained in this section were published after the publication of the developments proposed in this thesis (Roig-Flores et al., 2015; RoigFlores et al., 2016).

\subsubsection{Crack closure}

Crack filling or closure of a crack most straightforward consequence of self-healing, as in the human body is the closure of a wound. The techniques used to evaluate this crack closure include methods to evaluate both, surface and internal cracks, as well as several methods of image analysis. 


\subsubsection{Surface cracks}

The evaluation of surface cracks is the most straightforward method to evaluate selfhealing, and because of that it has been frequently used as a secondary method to visually support other tests results. A few studies have used it as the main method with broader data and thorough analyses. Several methods are used to evaluate crack closure, from the naked eye to microscopy techniques, such as:

- Photography cameras: Charge coupled device (CCD) or digital single-lens reflex (DSLR), programmed to take pictures periodically to register the appearance of cracks in big specimens during testing and after healing.

- Light microscopy (optical, digital and stereo): using visible light as the radiation font (Toledo Filho et al., 2005), (Homma et al., 2009) , (Ahn \& Kishi, 2010), (Jaroenratanapirom \& Sahamitmongkol, 2011), (Sisomphon et al., 2011; 2012), (Snoeck \& De Belie, 2012), (Van Tittelboom et al., 2012), (Ferrara et al., 2014). This is the most common method. Some microscopes have specific functions to get additional information about the composition of the healing products, such as polarized microscopy in thin sections (Sisomphon et al., 2012), (Çopuroğlu et al., 2013).

- Electron microscopy: using electron beams as the radiation font. Main types are Transmission Electron Microscope (TEM) and Scanning Electron Microscope (SEM). SEM has been used to analyze precipitates inside a healed crack and their composition rather than in evaluating the evolution of the crack size (Jacobsen et al., 1995), (Homma et al., 2009), (Ahn \& Kishi, 2010), (Jonkers et al., 2010), (Huang \& Ye, 2011), (Ferrara et al., 2014)

The methods that require the embedment of the sample, such as in the cases of thin sections or electron microscopy, do not allow to analyze one same crack before and after healing. This is a drawback that should be taken into account depending on the purpose of the study.

\subsubsection{Internal cracks}

Several studies showed that in some cases healing is able to close surface cracks (Sisomphon et al., 2012) but the effectiveness of a healing strategy has to be assessed also with reference to its ability to close the cracks internally. To this purpose, tomography techniques have been proposed, due to their use of penetrating waves, such as:

- X-ray Tomography: X-rays applied to an object are partially absorbed, depending on its density and composition, by exciting its electrons. This allows the differentiation between aggregate, matrix and voids (either pores or cracks).

- Neutron Tomography: neutron rays interact with atomic nuclei, showing different patterns from X-ray. Neutron Tomography has been used so far to visualize water uptake by a crack due to their highest hydrogen detection sensitivity (Van Tittelboom et al., 2013).

- Computerized Tomography scan (CT-scan): is a combination of X-ray images taken from different angles to create cross-sectional 2D images or 3D compositions. MicroComputerized Tomography $(\mu \mathrm{CT})$ is a type of CT for small scale objects with increased resolution and it has been successfully used to discern voids (Ranachowski et al., 2014) and internal cracks of concrete, (Van Tittelboom et al., 2011). Similar processing has been also made from neutron tomography images (Van Tittelboom et al., 2013). 
Table 2-4 summarizes the advantages and disadvantages of each method to evaluate selfhealing by means of crack closure. The most complete information comes from tomography techniques, which can display the cracks and also healing agents released from the capsules (Fig. 2-23). However, their very expensive equipment makes light microscopy the best cost-effective methods.

\begin{tabular}{|c|c|c|}
\hline Method & Advantages & Disadvantages \\
\hline $\begin{array}{l}\text { Photography } \\
\text { cameras }\end{array}$ & $\begin{array}{l}\text { - Largest area of visualization } \\
\text { - Allow acquisition of data during } \\
\text { testing. } \\
\text { - Easy continuous monitoring for fast } \\
\text { self-healing methods. }\end{array}$ & $\begin{array}{l}\text { - Generally, needs certain } \\
\text { distance to cover the whole } \\
\text { specimen } \\
\text { - Less detail for a specific } \\
\text { crack. }\end{array}$ \\
\hline $\begin{array}{l}\text { Light } \\
\text { microscopy } \\
\text { (optical, digital } \\
\text { and stereo) }\end{array}$ & $\begin{array}{l}\text { - Cheap and easy to implement. Easiest } \\
\text { preparation of samples. } \\
\text { - Light portable microscopes can be } \\
\text { programmed for monitoring cracks. } \\
\text { - Visualization of the surface crack as } \\
\text { seen by the eye at improved resolution, } \\
\text { showing natural colors. } \\
\text { - Larger area visualization } \\
\text { - Good results for } 0.05-0.30 \mathrm{~mm} \text { cracks }\end{array}$ & $\begin{array}{l}\text { - Not able to evaluate internal } \\
\text { crack width } \\
\text { - Not able to evaluate } \\
\text { composition of precipitates }\end{array}$ \\
\hline $\begin{array}{l}\text { Polarized } \\
\text { function for } \\
\text { light } \\
\text { microscopy }\end{array}$ & $\begin{array}{l}\text { - High contrast in the borders between } \\
\text { matrix and voids or cracks } \\
\text { - Allows identification of crystalline } \\
\text { solids from optical properties }\end{array}$ & $\begin{array}{l}\text { - Needs preparation of } \\
\text { samples with polarized epoxy } \\
\text { filter sets } \\
\text { - Only for discrete measures. } \\
\text { - A same crack cannot be } \\
\text { analyzed before and after } \\
\text { healing due to the } \\
\text { impregnation of the crack. }\end{array}$ \\
\hline $\begin{array}{l}\text { Electron } \\
\text { microscopy }\end{array}$ & $\begin{array}{l}\text { - Allows complementary tests of the } \\
\text { composition of precipitates. } \\
\text { - Generally, focus on small size cracks. } \\
\text { Good for verifying autogenous healing. }\end{array}$ & $\begin{array}{l}\text { - Expensive compared with } \\
\text { other light microscopy } \\
\text { techniques. } \\
\text { - Only in grey scale depending } \\
\text { on the atomic number of the } \\
\text { element. } \\
\text { - Only for discrete measures }\end{array}$ \\
\hline $\begin{array}{l}\text { Tomographies } \\
\text { and CT-scan } \\
\text { (X-rays and } \\
\text { neutron) }\end{array}$ & $\begin{array}{l}\text { - Internal crack evaluation, in the } \\
\text { damage and healing stage. } \\
\text { - Allows the differentiation by densities } \\
\text { of the materials } \\
\text { - In the case of neutron tomography, } \\
\text { high sensitivity for hydrogen detection, } \\
\text { good for analysis of water uptake }\end{array}$ & $\begin{array}{l}\text { - Extremely expensive and low } \\
\text { availability of equipment. } \\
\text { - Only for discrete measures }\end{array}$ \\
\hline
\end{tabular}

Table 2-4 - Advantages and disadvantages of commonly used methods to evaluate crack closing. 


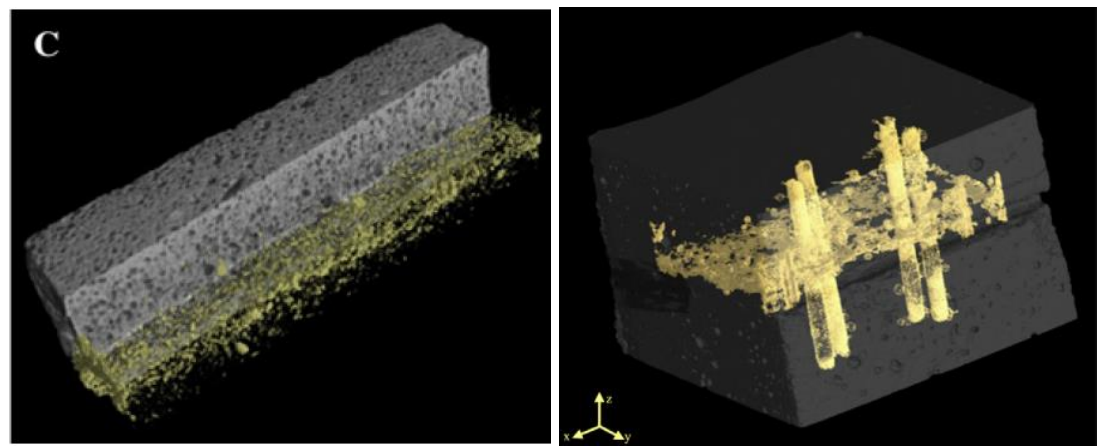

Fig. 2-23. Three-dimensional images of concrete showing the healing agent released inside the crack in yellow, from (Van Tittelboom et al., 2013) and (Van Tittelboom et al., 2011).

All of these methods are suitable for laboratory testing. In real structural elements their usage has been limited so far to the analysis of surface cracks with portable light microscopes or photography cameras.

\subsubsection{Image analysis and crack sealing indices}

Before taking images of the cracks, a specific pretreatment may be needed, even when using the most basic light microscopes. Some studies polish and impregnate samples with dye epoxy under vacuum before using a stereo microscope, polarized epoxy when using polarized light (Sisomphon et al., 2012), etc.

To analyze self-healing through crack closure, it is necessary to compare the initial crack width with its value after the healing process. Then, the points of analysis of crack width need to be decided before healing takes place. Self-healing being a random phenomenon, the broader the length of a crack that is analyzed, the higher representativeness will have the analysis.

The analysis of crack width needs the use of a size reference and standard photography software or specific measuring software from microscopes. The parameters that can be analyzed are:

- Crack width: measured at specific points (Jaroenratanapirom \& Sahamitmongkol, 2011), (Snoeck \& De Belie, 2012), (Van Tittelboom et al., 2012). It can be estimated by evaluating the area under the curve when representing initial vs final crack width (Jaroenratanapirom \& Sahamitmongkol, 2011), (Sisomphon et al., 2012), (Van Tittelboom et al., 2012).

- Crack area or volume: in a specific section (Kanellopoulos et al., 2015).

In the case of tomography, direct visualization of the volumes in black color (Van Tittelboom et al., 2013) shows the volumes of voids and cracks. After post-processing the results, selecting areas with different brightness values allow the selection and measurement of areas of different densities, and then, to estimate the volumes of pores and cracks (Homma et al., 2009; Ranachowski et al., 2014).

In general, the expression used for the evaluation of self-healing by crack closing follows the equation 2.11, were $w_{i}$ and $w_{f}$ are the initial and final crack widths, as used by Wiktor 
and Jonkers (2011), Jaroenratanapirom and Sahamitmongkol (2011) or Snoeck and De Belie (2012), among others.

$$
\text { Crack closing }(\%)=\frac{w_{i}-w_{f}}{w_{f}}
$$

In some cases, the parameter is a geometrical parameter of the crack, namely its width or area, but in the studies by Jaroenratanapirom and Sahamitmongkol (2011), Sisomphon, et al. (2012) and Van Tittelboom, et al. (2012), the previous formula was adapted to evaluate a global value using all the crack values, and calculating crack closure with the formula shown in equation 2.12 :

$$
\beta(t)=1-\frac{A(t)}{A_{i}}
$$

Where $\mathrm{Ai}$ is the area comprised between the bisecting line and the horizontal axis (in purple in Fig. 2-24), and $\mathrm{A}(\mathrm{t})$ is area comprised between the polyline that unites all the remaining crack width points and the horizontal axis (blue diagonal stripes in Fig. 2-24).

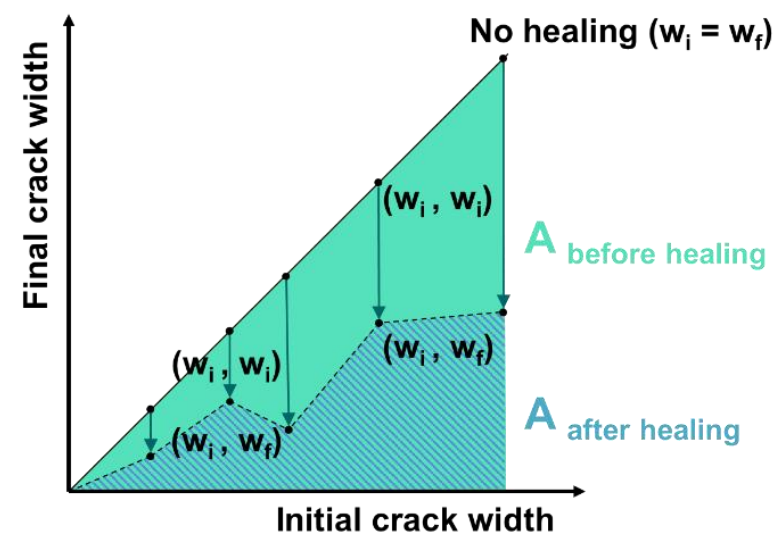

Fig. 2-24. Self-healing quantification method used in (Jaroenratanapirom \& Sahamitmongkol, 2011), (Sisomphon et al., 2012), (Van Tittelboom et al., 2012).

\subsubsection{Transport properties}

One of the main objectives of crack healing is to improve durability of concrete structures. Visual closing of cracks does not necessarily imply an improvement of durability. Therefore, studies of self-healing based on their transport properties are of a great importance.

One of the most distinguishing features of the evaluation of self-healing through transport properties in contrast with mechanical tests is the need of a previous precracking method.

The more important fluids that can enter concrete that are relevant to durability are water, which may carry aggressive ions, as well as physically bound gases such as carbon dioxide and oxygen (Neville, 2011). In uncracked specimens, transport depends on the properties of the hydrated cement paste. Permeability refers to flow through a porous medium, but in the 
case of concrete diffusion and sorption the objective is to determine the "penetrability" of concrete rather than strictly the permeability. These three mechanisms are (Neville, 2011):

- Permeability: flow under a pressure differential

- Diffusion: flow under a concentration differential

- Sorption: flow caused by capillary movement in the pores open to the environment. It only happens in partially dry concrete.

\subsubsection{Water permeability}

Regarding the permeability tests Desmettre (2011) proposed to differentiate between discrete and continuous permeability tests depending on the moment of the test:

- Discrete water permeability tests: (Dry, 2000), (Homma et al., 2009), (Yang et al., 2009), (Hosoda et al., 2009), (Sisomphon \& Copuroglu, 2011) (Sisomphon et al., 2012)

- Continuous water permeability test, healing occurs simultaneously: (Edvardsen, 1999), (Reinhardt \& Joss, 2003), (Li \& Yang, 2007), (Hosoda et al., 2009), (Van Tittelboom et al., 2012)

Traditionally, permeability in concrete has been evaluated in the uncracked state, as a measure of the capability of water to penetrate inside concrete matrix. This allows determining the penetration of the front of water and if it arrives at the reinforcement. In cracked specimens, the fluid flow passing through the sample at a determined pressure can be measured. The test methods for damaged or cracked specimens will be very similar to those for porous materials, such as in soil mechanics or hydrogeology, with a fluid flow passing through the sample.

Edvardsen $(1996 ; 1999)$ developed a test device able to induce tensile cracks in concrete samples and to evaluate water permeability with different water pressures (ranging from $2.5-20 \mathrm{~m}$ ). With this setup, permeability was evaluated simultaneously to the process of healing. The results showed that samples exposed to low water pressure achieved better healing rates. This test setup has been also used in later research (Homma et al., 2009).

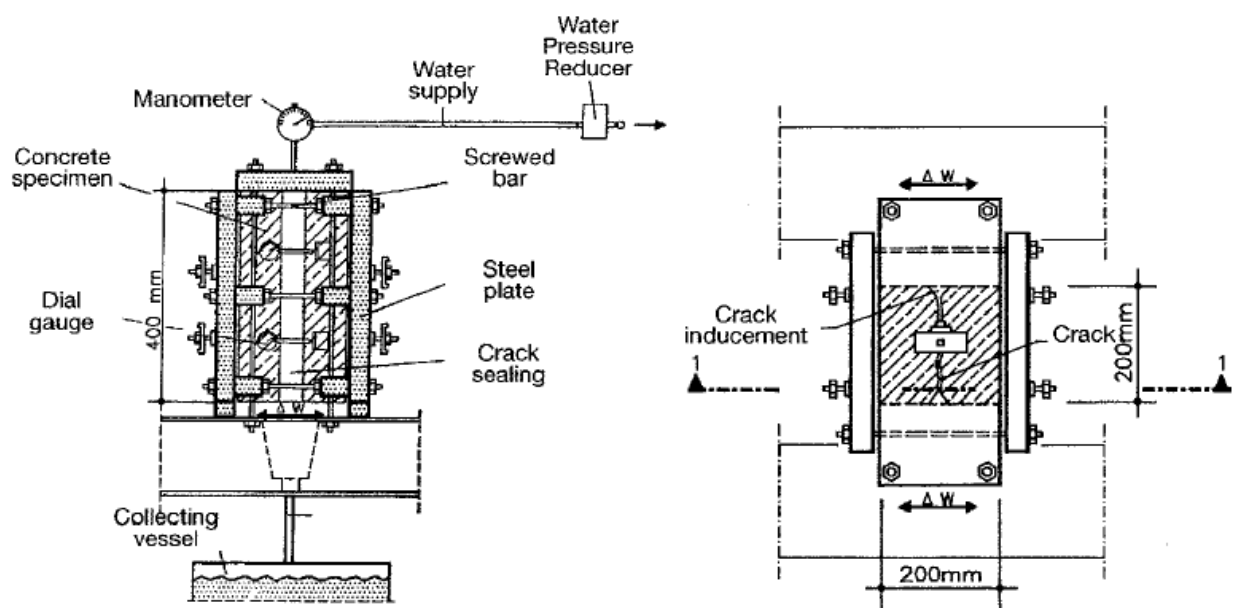

Fig. 2-25. Testing device for producing tensile cracks under water pressure (Edvardsen, 1999). 
Another water permeability test setup for cracked concrete found in the literature is the design by Aldea, et al. (1999). In this method, cylindrical specimens are sealed into a PVC ring using an epoxy resin. After that, specimens are vacuum saturated with tap water and placed in the test set-up (Fig. 2-27 left). In the top and bottom parts of the specimen a water-filled plexiglas tube is placed. The water permeability is evaluated as the reduction of water height in the pipette. This method has been successfully used for the evaluation of self-healing such as in (Van Tittelboom et al., 2010). Sisomphon, et al. (2012) used a similar version of this method, using a plastic cylinder and a PVC ring sealed with silicone, and maintaining a constant water level of $100 \mathrm{~mm}$.

Sisomphon, et al. (2012) obtained for the control mortar, slight reduction of water passing rate can be observed in the early period and the rates of reduction were gradually decreased between 5 and 7 days. However, after the water renewal, the water flow of all mortars increased again, which was thought to be produced by the dissolution of some healing products formed at early period in contact with fresh water.
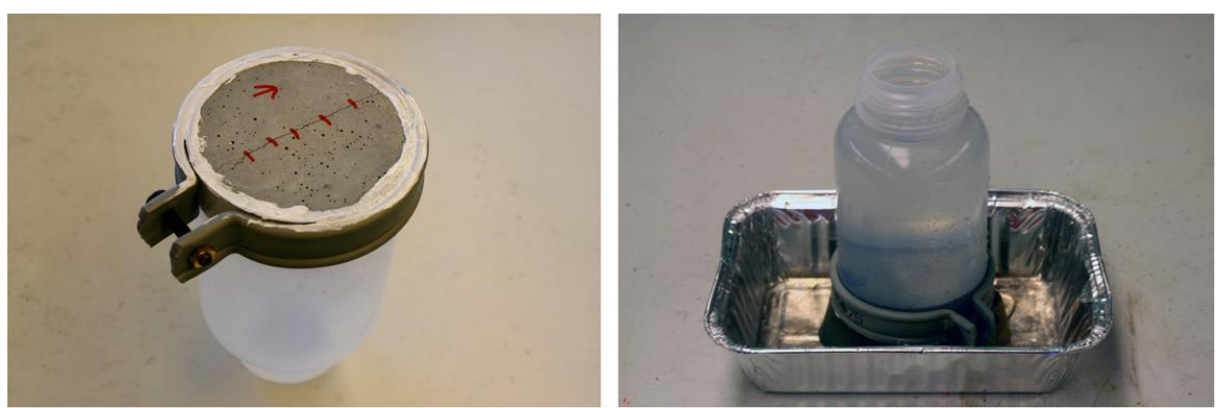

Fig. 2-26. Permeability test as used by (Sisomphon et al., 2012).

Other methods for the evaluation of water permeability used in the literature include an adapted version of RILEM test method for water absorption tube (Jiang et al., 2015).
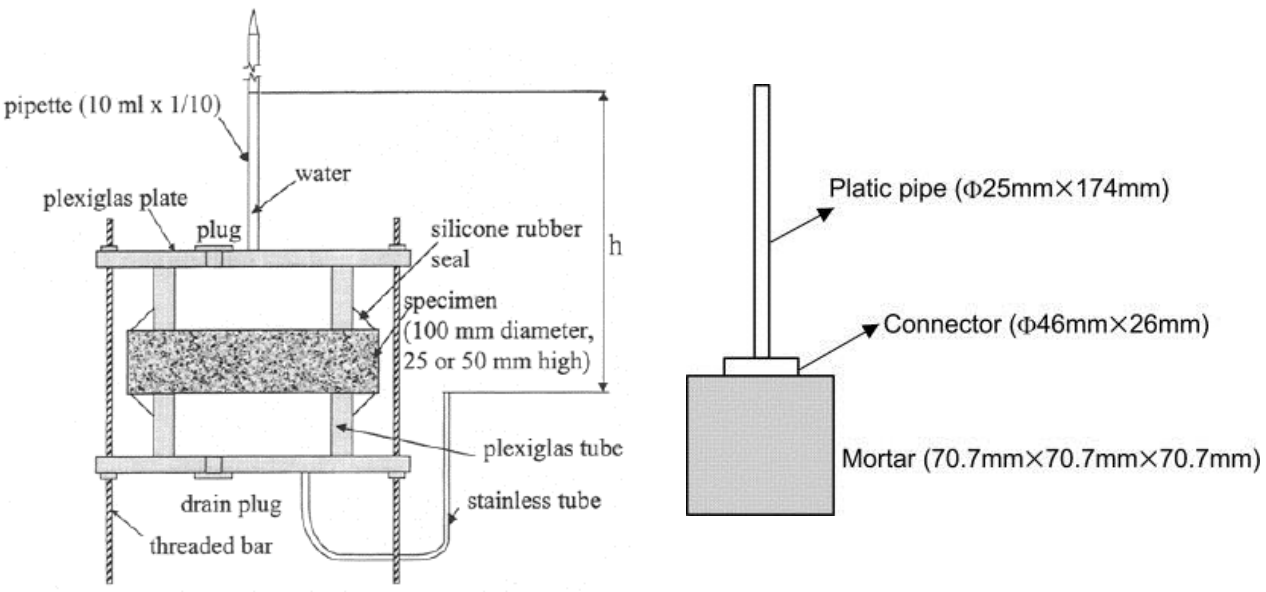

Fig. 2-27. Left: water permeability test setup used by (Aldea et al., 1999). Right: water permeability test setup used by (Jiang et al., 2015). 
Recent research shows that air bubbles affect the measures of water flow in the initial stages of water permeation through cracked concrete (Ikoma et al., 2015). This was observed directly by using acrylic resin and glass as transparent media over concrete surface, and air bubbles by probably capillary and surface tension forces in the relatively narrow spaces, which caused significant water flow reduction.

\subsubsection{Air Permeability}

The permeability and diffusion of gases are of great interest in some applications. For example, since the presence of carbon dioxide leads to carbonation of hydrated cement paste, and the presence of oxygen enhances the corrosion processes of steel reinforcements (Neville, 2011). In general, the air permeability tests used for self-healing consist on discrete measurements.

Yang, et al. (2011) used liquid methanol as the gas source on the mortar specimens after compression loading. They evaluated the weight variations of the specimen setup including the cell, liquid methanol, and disk specimen and epoxy sealer at the beginning of the test and at different times. The vaporization of methanol was recorded until a steady-state mass loss was reached, and the permeability coefficient is then calculated.

Gagné and Argouges (2012) designed a gas permeability cell which allowed to measure air flow through a single crack under controlled conditions of temperature, pressure and crack opening (Fig. 2-28). In this method, mortar sample is placed between two aluminum disks. An upstream pressure of $50 \mathrm{kPa}$ is applied, while the downstream pressure was the atmospheric. Lateral tightness was achieved applying a confining air pressure, $200 \mathrm{kPa}$, to compress a membrane covering the plates.

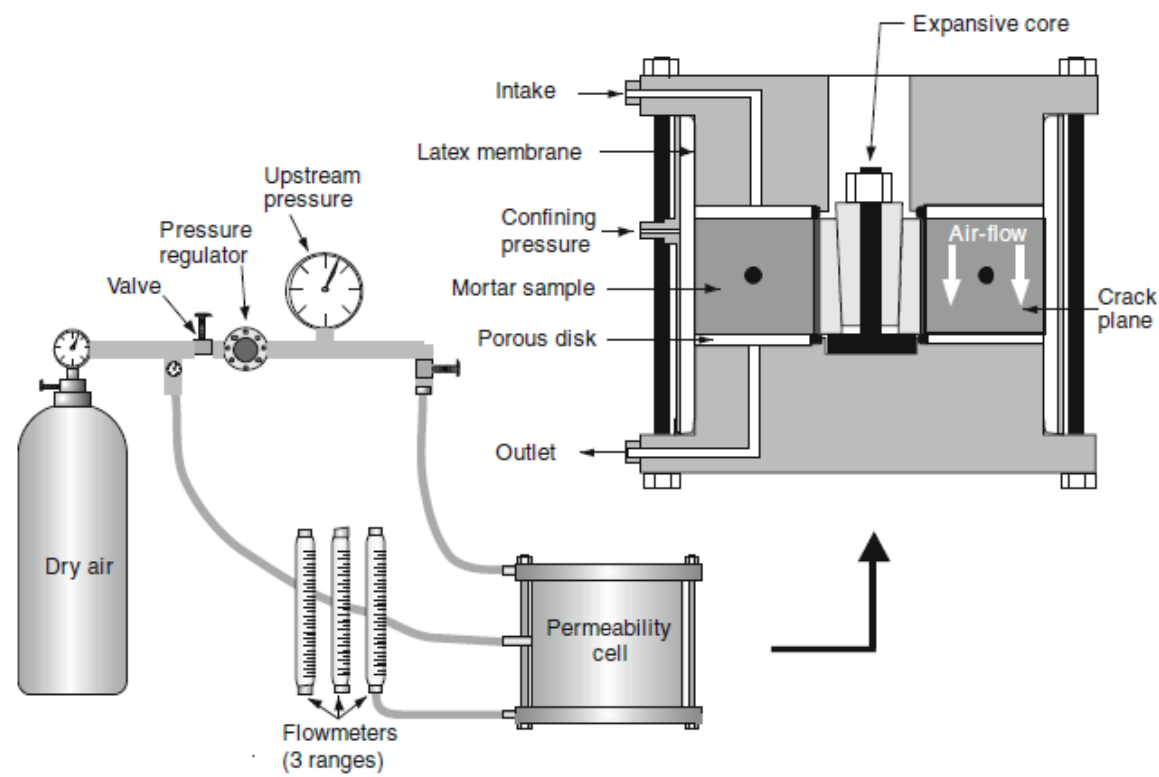

Fig. 2-28. Air-flow setup with a sectional view of the permeability cell (Gagné \& Argouges, 2012). 


\subsubsection{Water absorption and sorptivity}

Water absorption measure water flow produced by movement in the pores and capillaries. Sorptivity is an index that can be calculated from the to absorb capillary suction tests. Some authors have used these tests adapted for cracked concrete with a single crack to evaluate self-healing:

Wang, et al. (2012) and Zhang, et al. (2014) measured respecively water absorbed and sorptivity in the crack by isolating the zone around the crack with a waterproof paint (Fig. 2-29 left) or with a silicone coating in order to guarantee one directional flow through the specimen. In both cases, specimens were dried at 40 or $50^{\circ} \mathrm{C}$ in an oven before testing. The test were carried out following a modified version of RILEM 25 PEM II-6 and ASTM C1585 respectively, allowing only one surface of the specimen to be in contact with water, with a depth of approximately $5 \mathrm{~mm}$.

Alyousif, et al. (2015) verified that using sorptivity measurements samples with higher number of cracks had higher sorptivity values and when aging samples got reduced their sorptivity value. They used reference uncracked samples, as Pérez, et al. (2015).

Other authors have used very similar methods to evaluate specimens with internal microcracking due to freeze-thaw cycles (Sisomphon et al., 2011) or with multiple microcracking produced by compressing specimens (Jiang et al., 2015). In these cases, the bottom surface of samples was completely exposed to the water layer of $5 \mathrm{~mm}$.
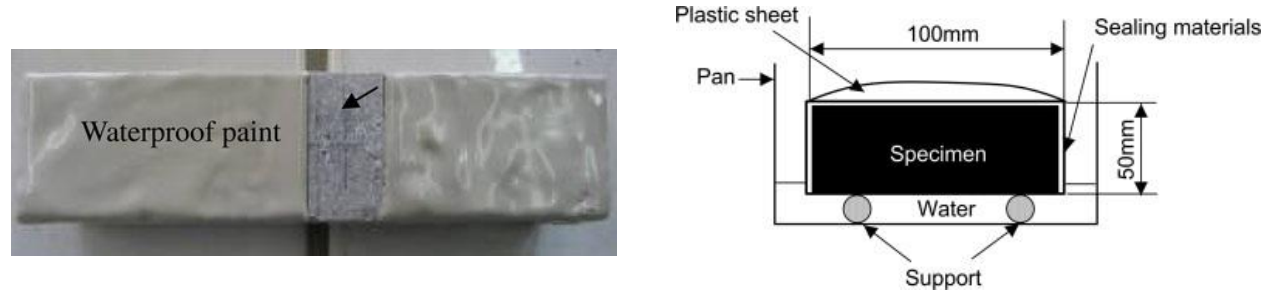

Fig. 2-29. Left: waterproof paint isolating the zone of the crack as used by Wang, et al. (2012). Right: test setup used by (Jiang et al., 2015).

\subsubsection{Other methods}

Other transport properties that have been analyzed to evaluate self-healing are chloride migration (Jacobsen et al., 1996), (Li \& Yang, 2007), (Sahmaran et al., 2013), (Yildirim et al., 2014), (Zhang et al., 2014) or the evaluation of the carbonation coefficient (Na et al., 2012). Darquennes, et al. (2016) achieved a clear relation of crack width with chloride migration coefficient, and they detected differences after the healing processes. They proposed that healed specimens could be regarded as specimens with smaller crack.

However, Parks et al. (2010) reported that chloride diffusion rates do not return to levels seen in virgin concrete when cracks are autogenously healed. According to these authors, the water permeability and chloride diffusion can be impeded to some extent regardless of the strength attained, and in their experimental analysis they did not detected carbonation of internal concrete surfaces. 


\subsubsection{Mechanical properties}

A true healing process should aim to recover not only water tightness but also mechanical recoveries of the damaged and healed zone. Regarding the recovery of mechanical properties, different test setups have been proposed in the literature, depending on the specific property of interest, which can be broadly classified in compressive, tensile or flexural tests.

\subsubsection{Flexural tests}

This test has been used widely for evaluating self-healing in samples with a single crack, usually using three points bending test in notched specimens, or with distributed cracks, usually using four points bending test without notch in highly reinforced samples.

Several studies have used three points bending tests, and in those cases, it is used simultaneously to produce a single crack in the specimens and to evaluate the mechanical properties (Fig. 2-30 left). In general, the methods follow the typical setup for three point bending tests in notched specimens, measuring displacement with LVDT's attached at the bottom of the specimen (Schlangen et al., 2006) (Van Tittelboom et al., 2011) or with crack mouth opening displacement (CMOD) sensors (Granger et al., 2007). The test is stopped at certain crack width opening or displacement, which will decrease after unloading. Afterwards, specimens are left to heal in certain conditions, depending on the self-healing mechanism, and they are tested again.

Other authors use four-points bending test, normally when they have fiber reinforcement with high contents, stress distribution, and therefore, multiple cracks (Fig. 2-30 right).
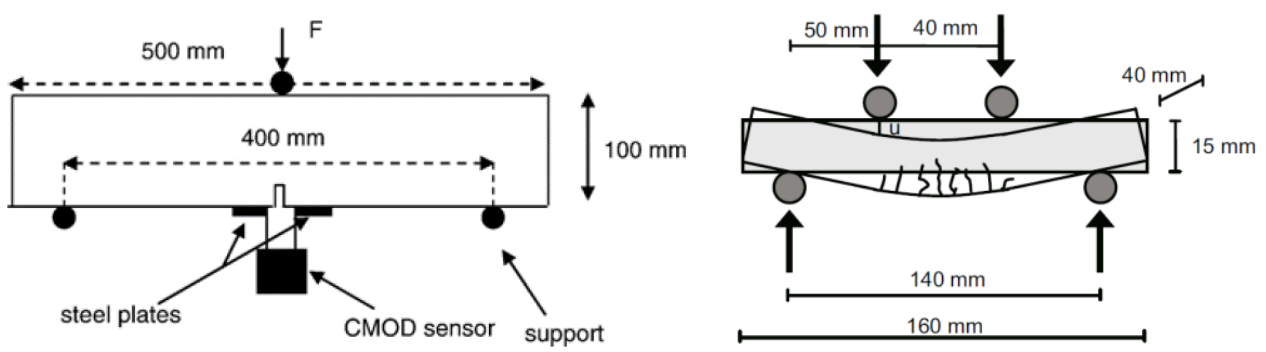

Fig. 2-30. Three points (left) and four points (right) bending tests setup (Granger et al., 2007) and (Snoeck et al., 2014).

\section{Three Points Bending Tests}

Granger et al. (2007) analyzed the load-displacement curves of UHPFRC specimens loaded up to $10 \mu \mathrm{m}$ of residual crack width. They evaluated the stiffness recovery by using the ratio stiffness with healing / stiffness without healing. The "stiffness with healing" corresponded to a cracked and reloaded specimen after the healing process, and the stiffness without healing was the reloading stiffness of a healthy specimen stored at laboratory, that was cracked and immediately reloaded at the final age. These authors, also conducted tests on specimens stored in water that were cracked and immediately reloaded 
at the final age, to compare if the different kinds of storage would affect the mechanical capacity (Fig. 2-31).

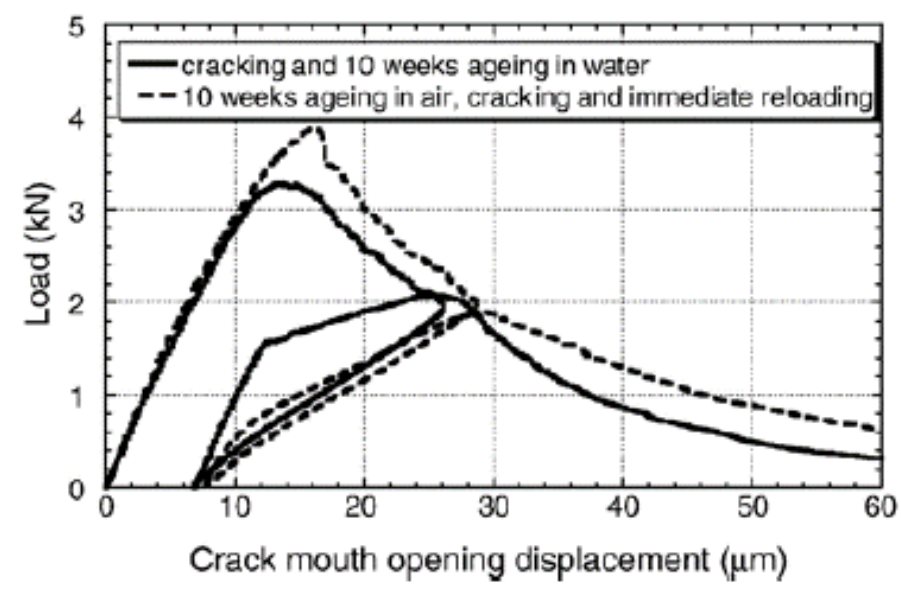

Fig. 2-31. Stiffness recovery of specimens cracked after 10 weeks of healing (Granger et al., 2007)

They obtained that storage in water does not improve the mechanical properties of the uncracked specimen, and then, the stiffness improvement produced when healing in water was assumed to be caused by healing. This healing is assumed to be produced by autogenous healing, mainly continuing hydration.

However it should be considered that those results were obtained in UHPFRC with very small crack widths. In that case, the adherence between the fibers and the matrix is not strongly degradated, and thus, the natural maturing effects and autogenous healing would potentially improve that adherence.

Taking as an example the results obtained by Granger et al. (2007), Fig. 2-32 shows diagram with the expected curves when having a healing response in terms of mechanical behavior. The equations used in the literature to evaluate mechanical recoveries will be expressed using this criterion, with this diagram as a basis.

Two main parameters have been analyzed in the literature, the strength or peak load $(\mathrm{P})$ and the stiffness $(\mathrm{K})$. Precracking curves will be all labelled with the number 1 , and the reloading curves with a 2 . The curves obtained in the reference specimens loaded and reloaded at the final age will be labelled as 1' and 2' respectively. The parameters referring to the unloading curve will have the sub index " $u$ ", and those referring to the residual state the sub index " $r$ ". This same analysis can also be applied for tensile and compressive strength tests. 

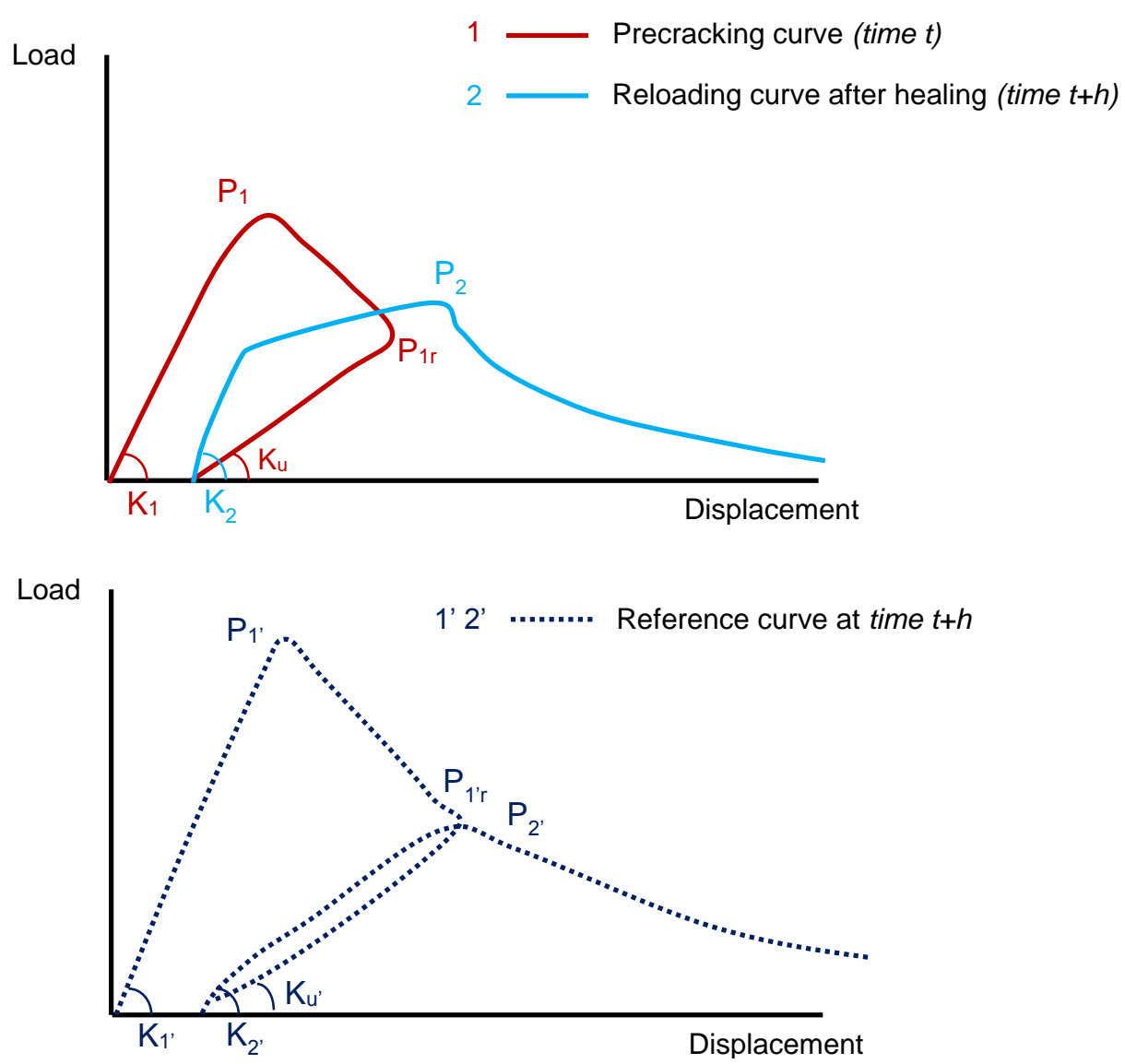

Fig. 2-32. Diagram with the curves and parameters involved for the evaluation of self-healing.

Using this notation, the equation followed by Granger et al. (2007) would be expressed as in (eq. 2.13):

$$
\text { Regain of } \mathrm{K}=\frac{K_{2}}{K_{2} \prime}
$$

In studies that reported recoveries with autonomous healing designs, Pelletier, et al. (2011) and Wang, et al. (2012) compared the load recovery after healing with its capacity before healing (eq. 2.14). Van Tittelboom, et al. (2011) also compared stiffness of the samples (joining points of origin and $0.04 \times$ peak load), which is equivalent to eq. 2.15.

$$
\begin{gathered}
\text { Regain of } \mathrm{P}=\frac{P_{2}}{P_{1}} \\
\text { Regain of } K=\frac{K_{2}}{K_{1}}
\end{gathered}
$$


Van Tittelboom, et al. (2012) and Ferrara, et al. (2014) proposed expressions based on a same structure, using parameters of a same specimen before and after healing, but introducing an additional parameter as reference. This parameter was the residual in the case of the strength recovery (eq. 2.16) and the unloading stiffness in the case of the stiffness recovery (eq. 2.17).

$$
\begin{aligned}
& \text { Regain of } P=\frac{P_{2}-P_{1 r}}{P_{1}-P_{1 r}} \\
& \text { Regain of } K=\frac{K_{2}-K_{u}}{K_{1}-K_{u}}
\end{aligned}
$$

On the contrary, Schlangen, et al. (2006) compared the results of healed specimens with those corresponding to virgin specimens stored at the same environment and with the same age as the healed specimens, similarly to the expression used by Granger et al. (2007). These reference specimens are first loaded in deformation control up to a displacement of $50 \mu \mathrm{m}$, unloaded and tested again. The maximum load reached in the second stage of the test is their reference value.

\section{Four Points Bending Tests}

Qian, et al. (2009) and Sisomphon, et al. (2013) used the four-point bending test and compared directly the parameters of strength and stiffness before and after healing.

Snoeck, et al. also used four-points bending test to form multiple small cracks (Snoeck \& De Belie, 2012; Snoeck et al., 2014). Force-displacement curves were transformed into stress-strain curve, and these parameters were used to evaluate the regain of stress at the point of formation of the first crack $\left(\sigma_{f c}\right)$, peak stress $\left(\sigma_{c u}\right)$, maximum capacity, and regain of elastic modulus, comparing the values obtained in the loading cycles before and after healing (from eq. 2.18 to eq. 2.20). The same formula structure was used for the regain of the two stresses and elastic modulus while direct comparison was used in the case of maximum capacity, using the same formula described in (2.14). However, in another study, Snoeck and De Belie (2015) used direct comparison for the regain of strength (eq. 2.20):

$$
\begin{gathered}
\text { Regain of } \sigma=\frac{\sigma_{2}-\sigma_{1 r}}{\sigma_{1}-\sigma_{1 r}} \\
\text { Regain of } K=\frac{K_{2}-K_{u}}{K_{1}-K_{u}} \\
\text { Regain of } \sigma=\frac{\sigma_{2}}{\sigma_{1}}
\end{gathered}
$$

\subsubsection{Tensile tests}

Tensile tests have been of wide interest due to their direct relation with cracks. However, tensile tests are in general hard to implement. Indirect tension tests (splitting tests) are easier to implement, but because of their smaller stability they have been mostly used as a precracking method, rather than a test for the evaluation of the mechanical self-healing.

One of the first works Hannant and Keer (1983) studied the tensile stress-strain curves for precracking and reloading for 4-10 $\mu \mathrm{m}$ cracks, comparing the values after healing with those of the uncracked specimens stored in the same conditions and at the same age.

Homma, et al. (2009) used direct tensile tests (see Fig. 2-33 left) in fiber-reinforced concrete, and compared the strength recovery as per the following expression (eq. 2.21): 


$$
\text { Regain of } \sigma=\frac{\sigma_{2}-\sigma_{1 r}}{\sigma_{1}-\sigma_{1 r}}
$$

Where, $\sigma_{1 \mathrm{r}}$ is the stress at the unloading in the first tension test ( $\sigma_{0}$ in Fig. 2-33 right), $\sigma_{1}$ is the tensile strength in the first tension test, and $\sigma_{2}$ is the tensile strength after self-healing.
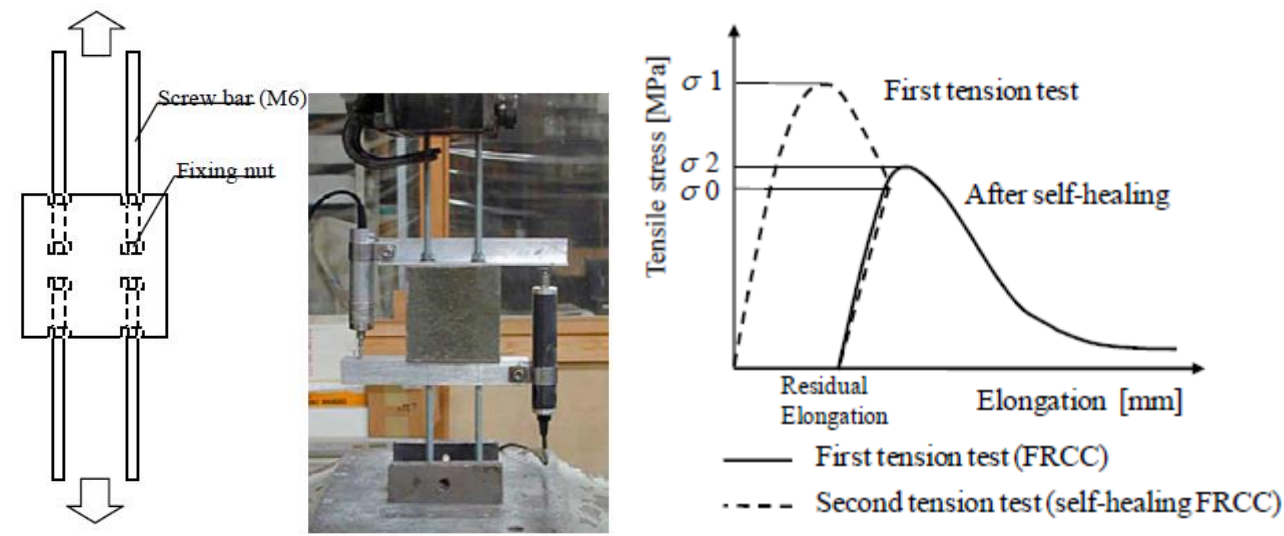

Fig. 2-33. Test setup of uniaxial tensile test and parameter to evaluate healing (Homma et al., 2009).

Several authors used uniaxial tensile test to produce multi-cracks in concrete with high amounts of fibers. Yang, et al. (2009; 2011) used uniaxial tensile to measure self-healing by tensile strength, strain capacity and stiffness in strain-hardening specimens, but also produced strain-softening specimens to control a single crack. Kim, et al. (2014) also used a tensile test for evaluating the mechanical recovery in fiber reinforced concrete with high contents of fibers, loading up to a tensile strain of $0.3 \%$, generating multiple micro-cracks. Similarly to the aforementioned cases, they measured the recovery as a ratio between the first cracking strength after healing and that of the same specimen before healing.

\subsubsection{Compressive tests}

This test has been used widely for evaluating self-healing in samples with distributed damage. Some authors also tested samples at cyclic compressive tests (Yang et al., 2011). Jacobsen, et al. (1996) used freeze-thaw tests as the damaging method, but evaluated selfhealing by comparing compressive strength of undamaged, damaged and healed samples. Similarly, Na et al. (2012) compared compressive strength of uncracked samples, with samples after deterioration by freeze-thaw cycles, with those healed at different conditions.

Zhong and Yao (2008) used a "Healing Degree" following the equation (equation 2.22), where $S_{h}$ is the compressive strength after healing and $S$ at the loading, and analyzed its relation with a "Damage Degree" that was expressed in terms of ultrasonic measurements.

$$
H=\frac{s_{h}-S}{S}
$$

Zhou, et al. (2011) tested specimens by compression at 28 days and measured self-healing as the increase of compressive strength before and after curing.

The evaluation of the mechanical recovery using compressive strength tests is a method easy to implement. This is the main reason for its broad use, however, it does not evaluate 
the mechanical recovery produced by healing of a crack, instead, it evaluates a global recovery of a microcracked element with distributed damage.

\subsubsection{Other tests}

Other authors performed tests on scaled-up concrete structural elements, such as Pang et al. (2011), studying a $2 \mathrm{~m}$ beam (flexural), a foundations column (shear) and a slab (impact), all of them containing glass tubes with an adhesive POR-15, and in all cases the criteria was to compare static stiffness obtained before and after healing.

Other mechanical tests that have been proposed for the evaluation of the self-healing effects on cement-based materials is specifically related with reinforced samples. Gray (1984) published the first studies on autogenous healing effect on the interfacial bond between steel fibers and mortar single-fiber pull-out specimens healed in water. The experimental campaign showed some hints of the self-healing effect. Later, Kim et al. (2014) also used pull-out tests to evaluate the effect of self-healing, depending on the shape of the fiber (hooked, smooth or twisted). These authors proposed that the mechanical recovery fiberreinforced concrete could be dependent on the pull-out resistance of pre-debonded fibers after healing. To quantify the effects on the pull-out resistance of the fibers, they evaluated the ratio between the maximum pull-out load after healing and before healing. They also took images with a CT-scan to visualize the damaged zones after the test (Fig. 2-34)
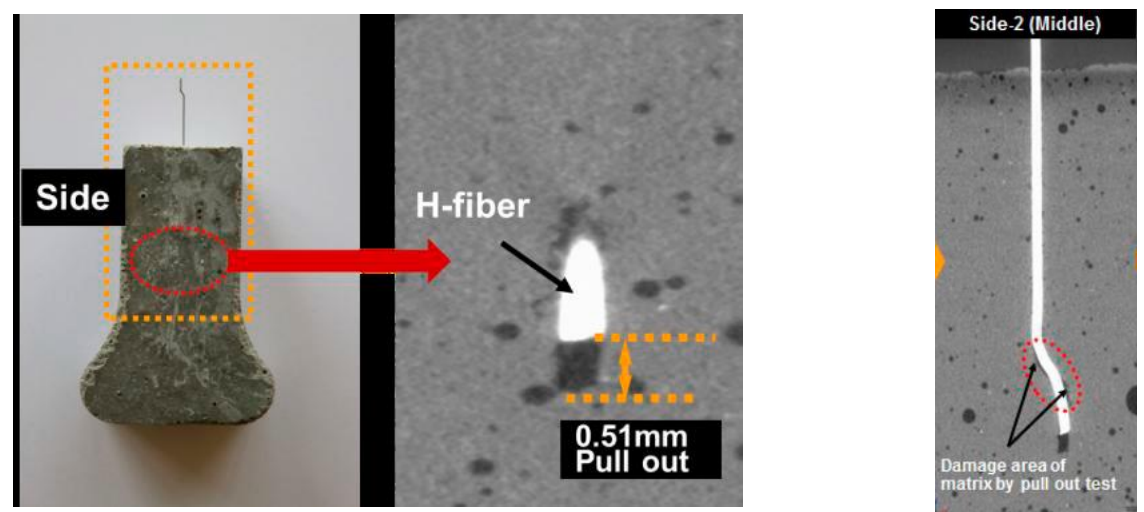

Fig. 2-34. CT-scan images of the damaged areas during the pull-out test for hooked fibers (Kim et al., 2014)

\subsubsection{Non-destructive testing}

Due to the difficulty of assessing the property of internal cracks, non-destructive testing has been also proposed, in the sense that they can give an indirect measure of several properties of concrete.

The most frequent method are the evaluation of the Resonant Frequency: (Jacobsen \& Sellevold, 1996), (Yang et al., 2009), (Yang et al., 2011), (Li \& Yang, 2007), (Li et al., 2011), (Yildirim et al., 2014), and the Ultrasonic Pulse Velocity (Zhong \& Yao, 2008), (Shahid et al., 2014), (Karaiskos et al., 2015), but other methods such as Acoustic 
Emissions (Granger et al., 2007), (Van Tittelboom et al., 2012) or Electrical Impedance (Yildirim et al., 2015) have been also used with this purpose.

\subsection{Discussion}

This chapter has presented different techniques reported in the literature for achieving selfhealing concrete from two main points of view: enhancing the autogenous healing properties of concrete and using autonomous healing specific designs. Both strategies have been mainly focused on healing service cracks (up to $0.3 \mathrm{~mm}$ ), and the most effective range is often for cracks in the range of the micrometers. Hence, at this stage of development, self-healing should not be considered as a method to repair critically damaged structures. Instead, self-healing is best used in a preventive manner, to increase the service life and reduce the maintenance costs of a structure.

\section{Autogenous healing:}

Enhancing the intrinsic autogenous healing of concrete is the most immediate way to achieve self-healing. However, autogenous healing is still not fully understood. From the literature, it can be thought that carbonation is the main process that causes autogenous healing, due to the composition of the precipitates, but several studies reviewed showed better autogenous healing efficiency for early age cracks, which would be related with continuing hydration.

Carbonation can lead to corrosion problems with the steel reinforcement due to a decrease of the $\mathrm{pH}$ inside the concrete matrix and the depassivation of the reinforcement. This makes carbonation undesirable in most concrete elements even if it improves autogenous healing. Moreover, the precipitation of calcium carbonate occurs at a quick rate in the surfacecontrolled phase (first 5 days) and at slow rate in the posterior diffusion-controlled phase (Edvardsen, 1999), which starts when the calcium carbonate layer does not allow direct contact of calcium ions with water. Because of all these reasons, autogenous healing by continuing hydration would be a more beneficial process, though it is not likely to happen in a complete absence of carbonation for structures in common conditions.

The composition of concrete seems to have a minor effect on autogenous healing, but some mixtures containing pozzolanas may have higher autogenous healing due to their delayed reaction. From the literature it seems that Blast Furnace Slag leads to better results compared with Fly Ash. Only a few studies have been performed regarding the effects of Silica Fume and Limestone Powder, which may also improve autogenous healing.

Reducing crack width using fiber-reinforced concrete with high volumes of fibers is a reliable method to achieve tighter cracks, which would then improve natural healing processes notably. However, the use of high contents of fibers or the application of compressive strength to close cracks, are methods that reduce the damage level (or crack width), but strictly speaking are not methods that produce self-healing.

Fiber-reinforced concrete, due to this tighter crack width, also presents higher durability, making it a potential concrete to synergize with autogenous healing to improve service life of structures. However, for the determination of the healing processes, the fibers may difficult the identification of healing. Concrete with high amounts of fibers could naturally 
present enough internal redistribution of stresses to produce new cracks instead of reopening those healed by autogenous healing. Because of that, the fact that old healed cracks do not reopen should not be considered as a sufficient evidence of a robust selfhealing material.

Regarding the material of the fibers, PVA fibers seem to promote the precipitation of crystals around the fiber compared with steel fibers or polypropylene fibers (Homma et al., 2009; Nishiwaki et al., 2012). Many studies reported in the literature have been performed in mixes that include PVA, even if their purpose was not analyzing the effect of this type of fibers, which could be increasing the autogenous healing of the mix and complicating achieving conclusions regarding the self-healing capacity given by a certain product due to the potential synergies.

Studies that focused on UHPFRC measured significant recoveries of properties, even of mechanical properties, for cracks up to $50 \mu \mathrm{m}$. However, several publications that focused on conventional types of concrete obtained almost complete crack filling or water permeability reductions for cracks up to $0.30 \mathrm{~mm}$, but without mechanical recoveries. The high dispersion in the healable crack width and the recoveries produced by autogenous healing can be produced by the differences in composition, healing conditions, cracking procedure or evaluation methods. Further studies to verify these reasons would allow not only to increase the knowledge on autogenous healing but also to predict at a practical level if a structure with certain size of crack will be able to heal naturally or not.

\section{Autonomous healing:}

The autonomous healing designs to achieve self-healing can improve or give different healing properties depending on the specific type. There is a wide range of tailored designs for autonomous healing in concrete, with different grades of development.

One of the main challenges for achieving self-healing is to protect the healing agents inside concrete and activate them only at the required moment. With this purpose, several encapsulation techniques are still being developed, either for bacteria or for chemical solutions. However, encapsulation adds the difficulty of resisting the casting process of concrete, which needs to be guaranteed before using them in construction. Located encapsulation can partially avoid that problem, as the tubes or capsules are placed before pouring the concrete, in a similar way to reinforcement. In any way, both types must resist the concrete impact in the moment of pouring while being activated by cracking (or other damage type) in the element.

Located encapsulation has higher healing capability because of the larger interior volumes, but requires crack prediction. Many authors used adhesive-type products as healing agents encapsulated in tubes and were those that achieved the best recoveries, including mechanical regain. However, in some cases the healing agent released from the tube has been reported as being only a small fraction of the volume embedded (Joseph et al., 2010). The viscosity of the healing agent and the diameter of the tubes will be critical for an effective release of the agent. In fact, tubes with inner diameter of $3 \mathrm{~mm}$ have been reported as more effective than those with inner diameters of $2 \mathrm{~mm}$ (Van Tittelboom et al., 2011).

Dispersed encapsulation answers to dispersed cracks, so it is more effective for random cracking, but the damage must hit the capsules. The different designs usually need an 
activator or catalyst, which can be introduced inside the composition of concrete (encapsulated or not) or can be provided by the environment, such as by the entrance of water. Most of the successful studies performed with microcapsules use very high amounts (around $4-7 \%$ in volume), which in some cases can be detrimental to other properties of the concrete, such as strength.

Because of the encapsulation difficulties, different groups have studied the use of admixtures with designed activation, such as crystalline admixtures, superabsorbent polymers and impregnated porous fibers or aggregates. Crystalline and expansive admixtures are commercially available products and have a good compatibility with concrete. Nevertheless, the self-healing properties that can be achieved when using crystalline admixtures are not clear enough, and expansive admixtures can lead to uncontrolled cracking due to excessive expansion. These designs present a more mature status concerning their addition into concrete, hence they could penetrate earlier in the construction industry.

The use of bacterial agents is also promising, but they still present some aspects that need further studies. One of them is the survivability of the bacteria in the concrete matrix, since the progressive reduction of the pore sizes in the concrete matrix diminishes the space they have available. The nutrients for the bacteria also need to be available in concrete, either added encapsulated or dispersed in the concrete matrix. The bacterial precipitation processes involved in self-healing will be affected by the external environmental conditions: humidity, temperature, $\mathrm{pH}$, etc. However, this process has generally been studied mostly at room temperature and freshwater, even though recent studies also showed their potential for marine environments (Palin et al., 2016). Then, further research is still needed to discern the optimal conditions for the bacterial-based healing.

Table 2-5 shows a summary of the advantages and disadvantages of the methods explained in this Chapter. It is should be highlighted that there is no standard methodology nor criteria to evaluate the self-healing properties of a material. The differences of methodologies and materials' composition difficult the comparisons between reported studies and the achievement of clear conclusions, since the testing methodology may influence them. 
Self-healing concrete: efficiency evaluation and enhancement with crystalline admixtures

\begin{tabular}{|c|c|c|c|}
\hline Group & Type & Advantages & Disadvantages \\
\hline \multirow{2}{*}{$\begin{array}{l}\text { Cement } \\
\text { healing } \\
\text { agent }\end{array}$} & $\begin{array}{l}\text { Autogenous } \\
\text { healing }\end{array}$ & Natural process. & $\begin{array}{l}\text { Low capability. } \\
\text { Low reliability. }\end{array}$ \\
\hline & $\begin{array}{l}\text { Encapsulation of } \\
\text { water }\end{array}$ & $\begin{array}{l}\text { Good compatibility of } \\
\text { healing products. } \\
\text { SAP and porous fibers. }\end{array}$ & $\begin{array}{l}\text { Low reliability of the activation. } \\
\text { Shrinkage of the SAPs after } \\
\text { drying }\end{array}$ \\
\hline \multirow{3}{*}{$\begin{array}{l}\text { Chemical } \\
\text { healing } \\
\text { agents }\end{array}$} & $\begin{array}{l}\text { None } \\
\text { encapsulation: } \\
\text { Admixtures } \\
\text { (CA\&CSA) }\end{array}$ & $\begin{array}{l}\text { Easy to add. } \\
\text { Good compatibility. } \\
\text { Availability of } \\
\text { commercial products }\end{array}$ & $\begin{array}{l}\text { Low reliability of the activation. } \\
\text { Low knowledge. } \\
\text { Inconclusive capability. }\end{array}$ \\
\hline & $\begin{array}{l}\text { Disperse } \\
\text { microencapsulat } \\
\text { ion }\end{array}$ & $\begin{array}{l}\text { Selection of designed } \\
\text { healing agents. }\end{array}$ & $\begin{array}{l}\text { Resistance of microcapsules } \\
\text { when casting and pouring. } \\
\text { Activation when cracking. } \\
\text { Decrease of compressive } \\
\text { strength of concrete. }\end{array}$ \\
\hline & $\begin{array}{l}\text { Located } \\
\text { capsules }\end{array}$ & $\begin{array}{l}\text { Selection of designed } \\
\text { healing agents. } \\
\text { High volume. } \\
\text { Short reaction time }\end{array}$ & $\begin{array}{l}\text { Resistance when pouring and } \\
\text { activation when cracking. } \\
\text { Viscosity of releasing agents. } \\
\text { Prediction of cracks. } \\
\text { Compatibility with cement matrix }\end{array}$ \\
\hline \multirow{3}{*}{$\begin{array}{l}\text { Biological } \\
\text { healing } \\
\text { agents }\end{array}$} & $\begin{array}{l}\text { None } \\
\text { encapsulation: } \\
\text { bacterial } \\
\text { solution }\end{array}$ & $\begin{array}{l}\text { Easy to add. } \\
\text { Compatible byproducts. }\end{array}$ & Low life expectancy of bacteria. \\
\hline & $\begin{array}{l}\text { Disperse } \\
\text { microencapsulat } \\
\text { ion }\end{array}$ & $\begin{array}{l}\text { Compatible byproducts. } \\
\text { Protection of bacteria. }\end{array}$ & $\begin{array}{l}\text { Resistance of microcapsules } \\
\text { when casting and pouring. } \\
\text { Activation when cracking. } \\
\text { Still in development. }\end{array}$ \\
\hline & $\begin{array}{l}\text { Located } \\
\text { capsules }\end{array}$ & $\begin{array}{l}\text { Compatible byproducts. } \\
\text { Protection of bacteria. }\end{array}$ & $\begin{array}{l}\text { Resistance when pouring and } \\
\text { activation when cracking. }\end{array}$ \\
\hline
\end{tabular}

\section{Experimental tests to evaluate self-healing:}

This Chapter has also reviewed the experimental tests used in the literature to evaluate selfhealing in concrete.

The evaluation of surface crack closure is the most frequently used method to evaluate selfhealing, due to the simplicity of the test and the accessibility of the equipment needed. The evaluation of the internal process by means of tomography (X-Ray, Neutron-Rays, etc.), however, is one of the most difficult and expensive methods, and so most of the studies on crack closure are only referred to its evaluation on the surface of the element.

Other frequently used methods for the evaluation of self-healing are modifications of existing tests, either for transport or mechanical properties, adapted for the evaluation of these properties in cracked specimens. Often, self-healing has been quantified by using conventional tests to measure target properties and comparing their values before the 
damage, just after producing the damage and, after certain amount of time in conditions that allowed healing.

Table 2-6 shows a summary of some of the methods used in the literature for the evaluation of self-healing, including their advantages and disadvantages.

\begin{tabular}{|c|c|c|c|}
\hline Group & Type & Advantages & Disadvantages \\
\hline \multirow{2}{*}{$\begin{array}{l}\text { Crack } \\
\text { closure }\end{array}$} & $\begin{array}{l}\text { Surface cracks } \\
\text { with light } \\
\text { micropscopes }\end{array}$ & $\begin{array}{l}\text { Straightforward method. } \\
\text { Affordable equipment. }\end{array}$ & $\begin{array}{l}\text { Limited only to surface } \\
\text { cracks }\end{array}$ \\
\hline & $\begin{array}{l}\text { Internal cracks } \\
\text { with tomography }\end{array}$ & $\begin{array}{l}\text { Complete analysis of the } \\
\text { internal phenomenon. }\end{array}$ & $\begin{array}{l}\text { Expensive equipment } \\
\text { and postprocessing. }\end{array}$ \\
\hline \multirow{3}{*}{$\begin{array}{l}\text { Transport } \\
\text { properties }\end{array}$} & Water permeability & $\begin{array}{l}\text { Different variations: with high } \\
\text { or low water pressure, } \\
\text { discrete or continuous } \\
\text { measures, etc. Useful when } \\
\text { watertightness is required. }\end{array}$ & $\begin{array}{l}\text { Blocking of the water } \\
\text { flow at some points or } \\
\text { the presence of } \\
\text { bubbles may hinder a } \\
\text { lack of internal healing. }\end{array}$ \\
\hline & Air permeability & $\begin{array}{l}\text { Different variations and types } \\
\text { of gases. Useful for } \\
\text { applications with high } \\
\text { security requirements. }\end{array}$ & $\begin{array}{l}\text { More complex setup } \\
\text { than the equivalent } \\
\text { water permeability test. }\end{array}$ \\
\hline & $\begin{array}{l}\text { Water absorption } \\
\text { and sorptivity }\end{array}$ & Setup easy to implement. & $\begin{array}{l}\text { Complicated } \\
\text { interpretation if cracks } \\
\text { are too large or too } \\
\text { small due to the lack of } \\
\text { suction. }\end{array}$ \\
\hline \multirow{3}{*}{$\begin{array}{l}\text { Mechanical } \\
\text { tests }\end{array}$} & Tensile tests & $\begin{array}{l}\text { Direct evaluation of the crack } \\
\text { mechanical properties. }\end{array}$ & $\begin{array}{l}\text { Hard control of the } \\
\text { cracking process }\end{array}$ \\
\hline & Flexural tests & $\begin{array}{l}\text { Cracking process easier to } \\
\text { control. }\end{array}$ & $\begin{array}{l}\text { Quantification of the } \\
\text { recoveries hard to } \\
\text { interpret due to the } \\
\text { presence of the } \\
\text { reinforcement }\end{array}$ \\
\hline & Compressive tests & Easy to perform. & $\begin{array}{l}\text { Complicated } \\
\text { interpretation in } \\
\text { relation with self- } \\
\text { healing a crack. }\end{array}$ \\
\hline $\begin{array}{l}\text { Non- } \\
\text { destructive } \\
\text { testing }\end{array}$ & $\begin{array}{l}\text { Resonant } \\
\text { frequency, } \\
\text { ultrasounds... }\end{array}$ & $\begin{array}{l}\text { Allows taking measures at } \\
\text { multiple times and during } \\
\text { testing. }\end{array}$ & $\begin{array}{l}\text { Indirect measure of } \\
\text { properties that indicate } \\
\text { the presence of the } \\
\text { crack, may not be clear } \\
\text { to interpret. }\end{array}$ \\
\hline
\end{tabular}

Table 2-6. Summary of advantages and disadvantages of methods the evaluation of self-healing

As explained in Section 1.1 "Background", the international scientific community is making an effort towards the standardization of the methods for the evaluation of selfhealing in concrete and other cement-based materials. Because of that, it is expected than in the next few years some advances will be achieved on this subject. 



\section{Chapter 3. Selection and development of the experimental methods}


Self-healing concrete: efficiency evaluation and enhancement with crystalline admixtures 
Chapter 3. Selection and development of the experimental methods

\subsection{Introduction}

This Chapter explains the different methodologies used in this thesis, some of them are new developments or modifications proposals based on already-existing tests. The Chapter is divided into six sections.

Section 3.1 is the introductory section and includes Subsection 3.1.1 exposing the specific developments proposed in this thesis, Subsection 3.1.2 for general considerations of the experimental work, Subsection 3.1.3 to explain the base concrete mixture proportions, Subsection 3.1.4 to list the CA used in this work and, Subsection 3.1.5 to explain the ambient conditions in which the healing process will be analyzed.

Section 3.2 explains concepts affecting the measure of crack closing and different quantification methods (Subsection 3.2.1) and the methodology followed when using crack closing as a secondary method to verify self-healing (Subsection 3.2.2).

Section 3.3 focuses on the proposal of a water permeability test, explaining the precracking procedure (Subsection 3.3.1), the preparation of the specimens (Subsection 3.3.2) and the details of the water permeability test proposed (Subsection 3.3.3).

Section 3.4 introduces some concepts to consider regarding the evaluation of self-healing by means of mechanical tests, depending on the reference for the comparison, which can be the same healed specimen before the healing process (Subsection 3.4.1) or an accompanying specimen (Subsection 3.4.2). Section 3.5 explains the method followed to use sorptivity measurements as an indicator of self-healing, including the explanation of the precracking procedure followed (Subsection 3.5.1) and considerations for the sorptivity test (Subsection 3.5.2).

Finally, Section 3.6 includes the characterization tests performed to concrete and mortars to verify their workability, the compressive strength and effect of crystalline admixtures in the hydration of the mix.

\subsubsection{Developments derived from this thesis}

This thesis makes several contributions to the evaluation of self-healing in concrete and also to the knowledge concerning the self-healing properties obtained when using crystalline admixtures.

Regarding the methodological developments, this thesis makes contributions especially to the methods based on crack closing measures and water permeability tests, but also introduces some considerations to water sorption and mechanical tests.

As explained in the literature section, crack width has been evaluated at specific points, frequently only one point per specimen, determined before the healing process, but not considering the whole length of the crack. In this thesis, several parameters related with the crack geometry are compared to be used as a self-healing indicator.

Regarding the evaluation of self-healing by water permeability measures, this work uses a specifically designed setup, which has some similarities with the method designed by Aldea et al. (1999) because of the shape of the specimens and distribution, but using pressured water by an attached water bomb as in the method used by Edvardsen (1999). The 
advantages of the setup proposed in this work is that this method uses a standard permeabilimeter for concrete, which is a clear benefit for its implementation in a laboratory. This work also analyses the relation between crack closing and water permeability parameters, which were also addressed by Edvardsen (1999) and Homma et al. (2009).

Concerning the recovery of mechanical strength, this work uses existing tests for the evaluation of the flexural strength of concrete (standards) but proposes and discusses new concepts and analysis criteria with works from the literature. The work presented regarding water sorptivity is the one implemented at University of Cambridge (Alghamri et al., 2016; Giannaros et al., 2016), introducing a methodological modification to isolate the sorptivity of the crack using accompanying specimens.

\subsubsection{General considerations for the experimental work}

The general methodology used to evaluate the effects of self-healing consists of five stages, as described in Fig. 2-22. These stages as used in this work are described in Fig. 3-1. The details for all these elements are described in detail in the sections of this Chapter.

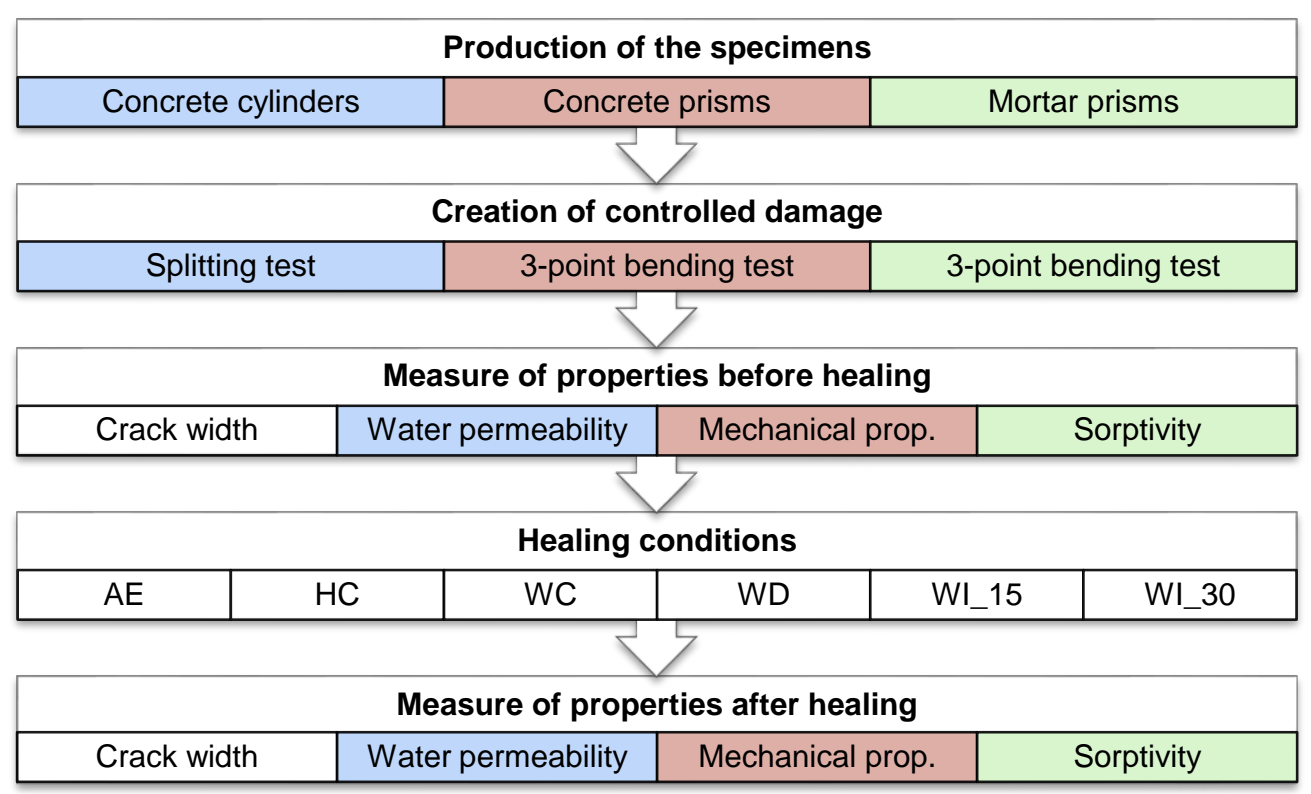

Fig. 3-1. Methodology procedure used in this work

Due to the differences in the geometries of the specimens in water permeability and mechanical tests, different precracking methods were used. Three point bending tests is the method used for precraking and to study the mechanical properties in prismatic notched specimens, while in the case of water permeability, splitting test was performed to precrack the cylindrical specimens. Crack width was analyzed in all the tests, to verify the filling of the cracks, and the healing conditions were decided depending on the purpose of each campaign. 
Chapter 3. Selection and development of the experimental methods

Since the study of the self-healing needs to produce cracks in concrete specimens, it is highly convenient to use reinforcement. This reinforcement needs to permit an effective action both in controlling crack width during the precracking process as well as in keeping fixed its value afterwards. This work uses steel fibers as a reinforcement to control crack width in the campaigns performed in concrete and steel wire in those in mortar. Steel fibers were selected due to their better performance for structural uses.

\subsubsection{Base concrete mixture proportions}

Reference concrete with $60 \mathrm{~kg} / \mathrm{m}^{3}$ (volume $=0.75 \%$ ) of steel fibers were first developed for this work. Since an excessive branching was detected in the precracking stage, it was later reduced to $40 \mathrm{~kg} / \mathrm{m}^{3}$ (volume $=0.50 \%$ ). The fibers used were Dramix RC 65/35 BN from Bekaert, with hooked-end steel, and dimensions of $35 \mathrm{~mm}$ length, $0.54 \mathrm{~mm}$ diameter.

The mixture proportions were decided to have a standard and a good quality concretes (see Table 3-1), with slump flow of around 120-140 mm. The superplasticizer used were Sika ViscoCrete-5720 and Sika Viscocrete 5980, their dosage was adjusted to reach the required slump flow, with contents between 1 and $1.5 \%$ by cement weight.

The cements used were Cement II/A-L 42.5 R from Elite Cementos and CEM I/42.5 R from Lafarge. This was decided to avoid the presence of pozzolanas, since they can potentially affect the autogenous healing and crystalline-admixtures healing reactions. The use of a cement with limestone powder was used when a CEM I was not available, and was discussed with the suppliers of the CA as an appropriate solution.

The aggregates used were calcareous crushed coarse and mixed siliceous-calcareous fine aggregate and calcareous filler. The CA was added in all cases in substitution of the sand content.

\begin{tabular}{ccc}
\hline & w/c=0.45 & w/c=0.60 \\
\hline Material $\left(\mathbf{k g} / \mathbf{m}^{\mathbf{3}}\right)$ & Control & Control \\
Cement & 350 & 275 \\
Water & 157.5 & 165 \\
Gravel (4-12 mm) & 950 & 908 \\
Natural sand & 899 & 987 \\
Steel fibers & 40 & 40 \\
Limestone powder & 50 & 50
\end{tabular}

Table 3-1. Base composition of the concrete types used in this work.

In the case of the sorptivity campaign, performed in mortar specimens, the mixture proportions followed EN 196-3 and the cement used was CEM I/52.5 R, again without mineral additions. In this case, a single steel wire was introduced in each specimen as the reinforcement, since the use of fibers could affect the adsorption of water inside the crack's section due to their random distribution.

For the sake of clarity, during the description of the experimental results, the specific composition used in that campaign will be shortly described. 


\subsubsection{List of CA and oxide composition}

The properties of crystalline admixtures are not clearly specified in standards. The study of the oxide contents of the crystalline admixtures used in this work can give an overall idea of the type of product that is being used and the similarities between the CA used. Table 3-2 shows the oxide contents obtained for the crystalline admixtures used in this work, type $\mathrm{A}$, which is the most used in this work, type B, and type $\mathrm{C}$, the last one also used in the literature. Type D was not analyzed since it was received at a later stage. The type of CA used in each experimental campaign depended on external reasons. CA types B and D were received as improved versions of type A.

\begin{tabular}{|c|c|c|c|c|}
\hline Oxide & Type A & Type B & Type C * & Type D \\
\hline $\mathrm{Al}_{2} \mathrm{O}_{3}$ & 1.006 & 0.295 & 3.66 & Not analyzed \\
\hline $\mathrm{CaO}$ & 45.914 & 40.427 & 73.40 & \\
\hline $\mathrm{Cr}_{2} \mathrm{O}_{3}$ & 0.007 & 0.001 & & \\
\hline $\mathrm{CuO}$ & 0.004 & 0.003 & & \\
\hline $\mathrm{Fe}_{2} \mathrm{O}_{3}$ & 1.191 & 0.142 & 2.28 & \\
\hline $\mathrm{MgO}$ & 0.571 & 12.255 & 0.70 & \\
\hline $\mathrm{MnO}_{2}$ & 0.127 & 0.018 & & \\
\hline $\mathrm{ZnO}$ & 0.019 & 0.008 & & \\
\hline $\mathrm{Na}_{2} \mathrm{O}$ & 2.618 & 0.082 & 1.24 & \\
\hline $\mathrm{K}_{2} \mathrm{O}$ & 0.297 & 0.145 & 0.40 & \\
\hline $\mathrm{SiO}_{2}$ & 6.567 & 0.947 & 13.72 & \\
\hline $\mathrm{SrO}$ & 0.020 & 0.018 & & \\
\hline $\mathrm{TiO}_{2}$ & 0.069 & 0.014 & & \\
\hline $\mathrm{P}_{2} \mathrm{O}_{7}$ & 0.124 & 0.044 & & \\
\hline $\mathrm{SO}_{3}$ & 0.885 & 0.045 & 3.91 & \\
\hline LOI & 41.251 & 43.670 & & \\
\hline Free $\mathrm{CaO}$ & 0.224 & 2.928 & & \\
\hline$I R$ & 1.500 & 3.620 & & \\
\hline
\end{tabular}

Table 3-2. Oxide composition of two of the used CA. * values from (Sisomphon et al., 2013).

The composition shows that the majority of the compounds of type A and B are volatile materials, which can be combined water and carbon dioxide from carbonates, because of their high values of Loss of ignition (LOI). Type B has higher Insoluble Residue (IR) values than type $\mathrm{A}$.

Type A and B have also high amount of calcium oxide and type A considerable amount of silicon oxide followed by sodium oxide. Crystalline admixture type B has considerable amount of magnesium oxide, which is known to be an expansive agent, and could be a potential product to have an effective filling of the crack. The high amount of calcium oxide and LOI suggests that most of these materials were close to calcium carbonate, with other compounds based on sodium or magnesium depending on the type of CA. 
Chapter 3. Selection and development of the experimental methods

Type C showed mostly calcium oxide and silicon oxide, both common compounds in cement and mineral additions used in concrete, but also has sulfur trioxide (Sisomphon et al., 2013). The compositions of type A has sodium oxide as the one used by (Jaroenratanapirom \& Sahamitmongkol, 2011). The fact that these three crystalline admixtures show different compositions may indicate different effectiveness and behaviors under the global name of "crystalline admixtures".

\subsubsection{Exposure simulation}

The environmental exposure is of major importance to analyze the activation of autogenous healing and crystalline admixtures. CA are expected to behave with different rates of effectiveness under different conditions, mainly depending on the available content of environmental water, analogously to what has been reported for autogenous healing.

In this work, several environmental exposures have been studied in order to determine the effect of humidity on the self-healing capability of concrete as per autogenous healing and crystalline admixtures. Each type of healing exposure has been designed with the objective of simulating real conditions (Table 3-3):

\begin{tabular}{|c|c|c|}
\hline Name & Real condition & Simulation in the laboratory scale \\
\hline $\begin{array}{l}\text { AE } \\
\text { (Air } \\
\text { Exposure) }\end{array}$ & $\begin{array}{l}\text { Concrete elements without } \\
\text { direct contact with water and } \\
\text { average humidity levels }\end{array}$ & $\begin{array}{l}\text { Storage of the specimens in normal } \\
\text { laboratory conditions inside a room without } \\
\text { exterior influences, } 17 \pm 1^{\circ} \mathrm{C} \text { and } 40 \pm 5 \% \text { of } \\
\text { relative humidity }\end{array}$ \\
\hline
\end{tabular}

\section{Concrete elements without \\ direct contact with water but \\ chamber) constructed in a high humidity environment}

Elements with a face directly exposed to water with low WC pressure, additional to the (Water atmospheric, and the other contact) unexposed to it, such as buried walls under the water table

WD (Wet/dry Structures periodically immersed in water and cycles) periodically exposed to a normal humidity environment

WI_15

(Water immersion)

WI_30

(Wäter immersion)
Underwater concrete elements

\section{Underwater concrete} elements in a warm water condition or an accelerated version of WI_15
Storage of the specimens inside a standard humidity chamber at $20^{\circ} \mathrm{C}$ and $95 \pm 5 \%$ relative humidity

A layer of water with a head pressure of 2 $\mathrm{cm}$-water on the top crack, and storage in humidity chamber at $20^{\circ} \mathrm{C}$ and $95 \pm 5 \%$ relative humidity. Additional water must be supplied when necessary in order to maintain the 2-cm water layer

Water immersion at $15-16^{\circ} \mathrm{C}$ and air exposure alternated with a defined regime, without renewing water.

Continuous immersion in tap water at laboratory conditions without renewing the water during the healing period (temperature of water, $15-16^{\circ} \mathrm{C}$ )

Continuous immersion in tap water at laboratory conditions without renewing the water during the healing period (temperature of water, $30^{\circ} \mathrm{C}$ )

Table 3-3. Exposure conditions of interest and simulation in the laboratory. 
With these environmental conditions, it is intended to discern if the self-healing will be powerful enough for constructions in several types of environments, including those without direct contact with water and those elements in contact with it, either having a small amount of water in contact or totally immersed.

The setup for the 2 centimeters water contact environment is shown in Fig. 3-2. The equivalent pressure of those $2 \mathrm{~cm}$ of water is $1.96 \times 10^{-3}$ bars or $0.2 \mathrm{kPa}$, without other pressure than the atmospheric in lateral faces of the specimen. With this setup, water remains in the upper PVC ring, enters inside the specimen through the crack and does not exit from it because of the lower sheets of insulation material and wood. This design was conditioned by two requirements: the system should not add an extra day, thus adhesivebased products were not suitable; and the designed system should not be permanent, and be easily removable, to permit intermediate permeability tests. After that, specimens are stored inside humidity chamber at $20^{\circ} \mathrm{C}$ and $95 \%$ of relative humidity to minimize water evaporation.

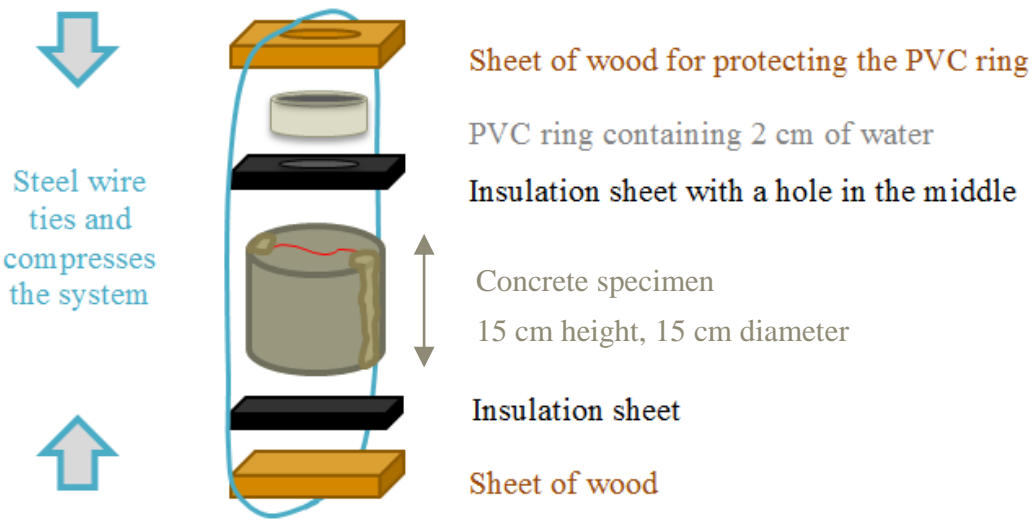

Fig. 3-2. Setup of the $2 \mathrm{~cm}$ water head exposure.

The specimens immersed in water during the healing period were divided in two different water recipients, to avoid interferences between control concrete and concrete with crystalline admixtures. The immersed specimens were placed on two $3 \mathrm{~cm}$ wide wood strips ensuring a separation between specimens of at least $5 \mathrm{~cm}$ between the cracked faces and $1 \mathrm{~cm}$ between the lateral surfaces, to let the water act in the whole specimen. For immersed specimens (either at $15^{\circ} \mathrm{C}$ or $30^{\circ} \mathrm{C}$ ) and in water contact it was necessary to add extra water each 2 or 3 days in order to maintain the same water level. The specimens were placed with the surface cracks in a lateral position. Fig. 3-3 shows concrete specimens in the laboratory exposed to these six exposures. 
Chapter 3. Selection and development of the experimental methods

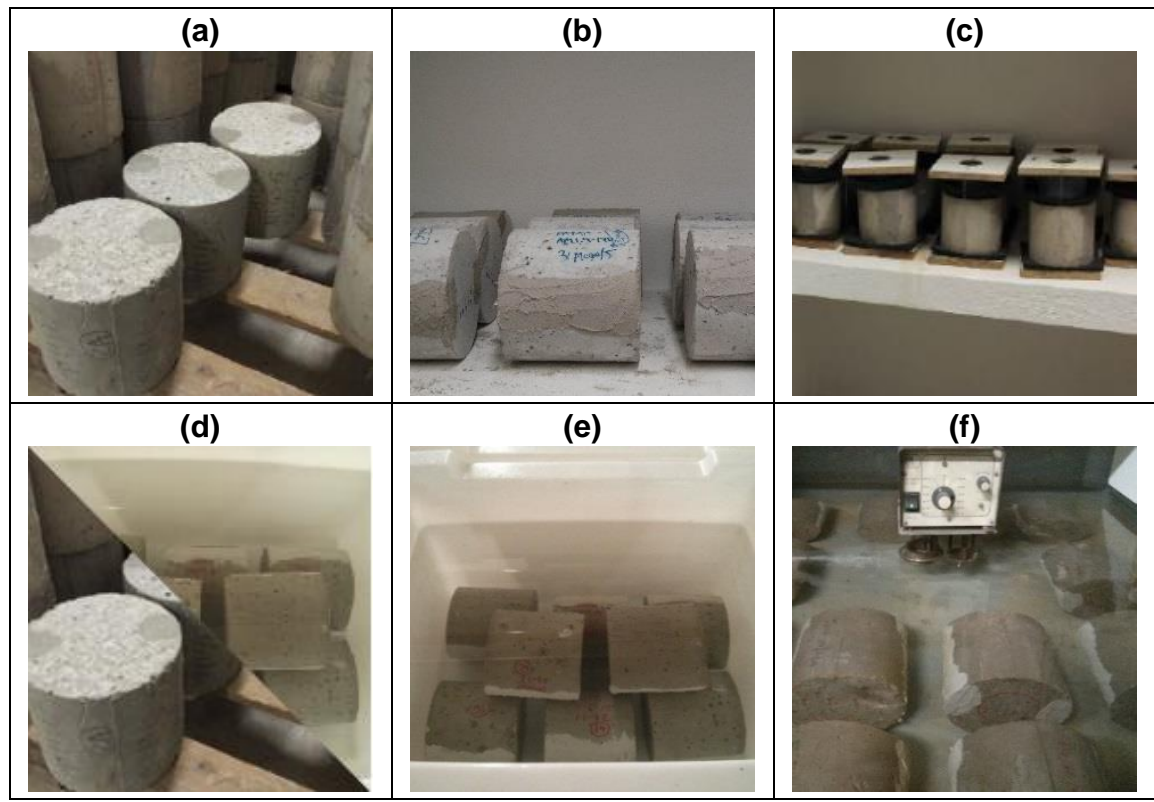

Fig. 3-3. Specimens under six exposures: air exposure (a), humidity chamber (b), water contact (c) wet/dry cycles $(d)$, water immersion at $15^{\circ} \mathrm{C}(e)$ and water immersion at $30^{\circ} \mathrm{C}(f)$.

\subsection{Crack closing test}

Crack width closure is the most straightforward consequence of self-healing, as in the case of wound healing. The process of crack closure can be distinguished at the naked eye, but specific devices and methodologies are needed to have a precise quantification.

In this work, two devices have been used to measure crack width: an optical USB microscope (PCE-MM200) and a microscope Leica S6D with a camera DFC 295, both able to show cracks in real time on a computer (Fig. 3-4).
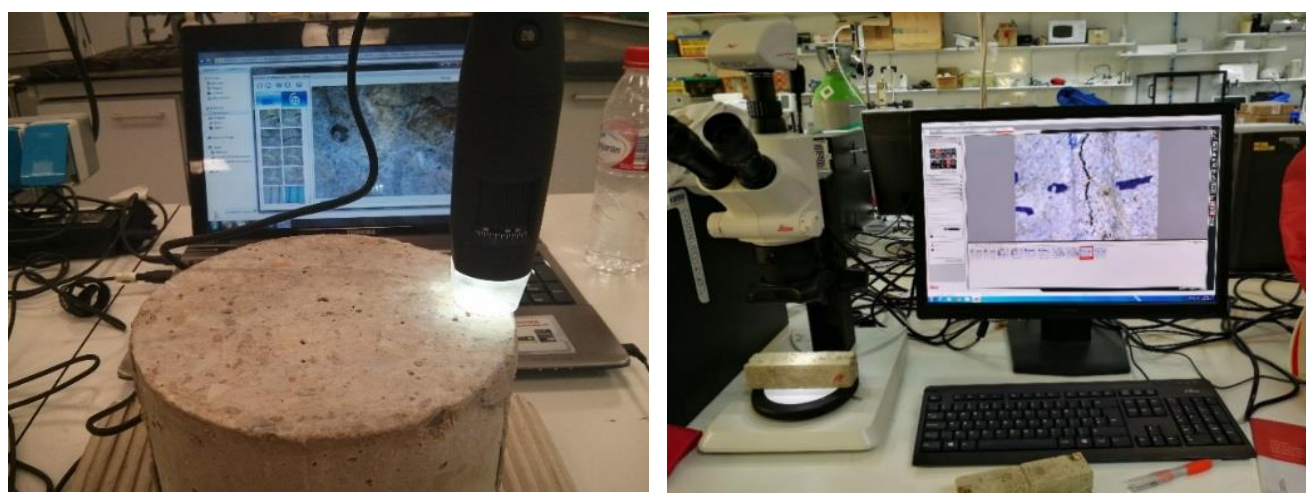

Fig. 3-4. Concrete specimen and optical USB microscope (left) and mortar specimen in the Leica stereomicroscope (right). 
The microscopes have LEDs to provide a light source and achieve clear images. A crack width ruler to measure crack width was used as the reference to calibrate the measures, in addition with the specific software of the microscope. The photography software Adobe Photoshop CS6 was the tool chosen to take evaluate the measures of width on each crack. In the second case, the specific software provided by the microscope supplier was used for the measures.

Pictures were taken before and after the healing period to evaluate autogenous and selfhealing and, before taking pictures, all the concrete specimens were cleaned with compressed air. For those specimens that healed the last days in water immersion, a preconditioning is necessary before taking the pictures of the crack after healing, otherwise, the LEDs would reflect the light due to the water located inside the crack. Usually, around 2 hours of drying at laboratory conditions are enough for having a dry surface.

\subsubsection{Types of evaluation}

Crack geometrical parameters can be divided in two groups: the measure of crack width and the measure of crack area. Crack area was expected to be a better indicator of the physical closing, because it would include the crack width all along the whole length of the crack. As explained in the literature section, crack width has been frequently evaluated at specific points determined before the healing process, but not considering the whole length of the crack. Moreover, in the literature there are no comparisons of the different types of measures.

To carry out this comparison, composed panorama pictures showing the cracks in all their length were prepared, using individual photos of the crack taken at different points of the crack length. These individual photos were composed using the "auto-align" option of the software Adobe Photoshop CS6.

Once these panorama pictures of the cracks are prepared, the four crack geometrical parameter can be measured:

- $w_{\max }$, maximum crack width: by means of graphic software, the maximum crack width along the whole crack length is determined, in millimeters.

- $w_{\text {avg, }}$, average crack width: by means of graphic software, crack width (in millimeters) is determined in five fixed positions and averaged. The five positions were prescribed positions along the crack. A grid was prepared to overlap on the panorama pictures, (Fig. 3-5). Different grids were prepared for the different crack lengths (this is because of a specific feature of the water permeability test that will be explained in Section 3.3.)

- $A_{\text {est }}$, crack area estimated from average crack width $\mathrm{w}_{\text {avg }}$ : using the five measures of crack width and multiplying by their associated lengths, in squared millimeters. In this way, the resulting area is approximated as the sum of the areas of five rectangles.

- $A_{p x}$, crack area measuring black pixels: by using graphic software, black pixels in the image are counted, indicating the crack area. This measurement requires the following procedure. First, the USB microscope was adjusted to use the maximum light possible before taking the individual pictures. After creating the panorama from the individual pictures, the brightness and contrast of each picture were averaged using the "AutoBlend" tool to have seamless tones and colors. Since 30 or more pictures were used in 
each composition image, this averaging ensures that any brightness or color aberration in the pictures would be corrected. Prior to counting the black pixels, all the panoramas were cleaned using the specific tool of the software (Fig. 3-6). This last step avoids any distortion due to pores in the specimen or other dark parts of the picture that are not part of the crack. The selection of the black pixels was performed selecting pixels with hex color code $\# 000000$, with a fuzziness level of 100 .

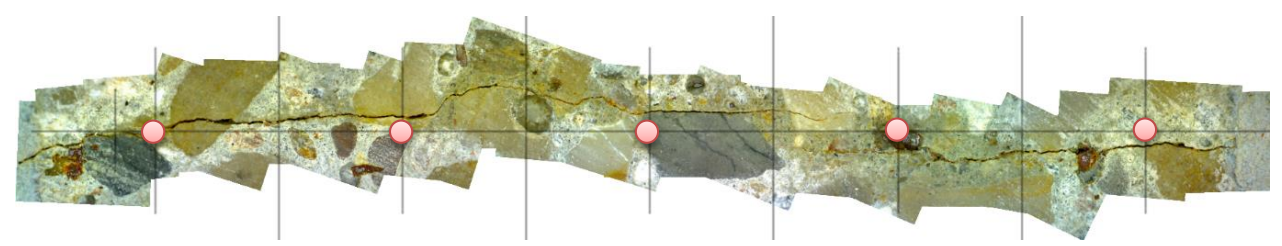

Fig. 3-5. Panorama of a top crack and grid marking the measuring points.
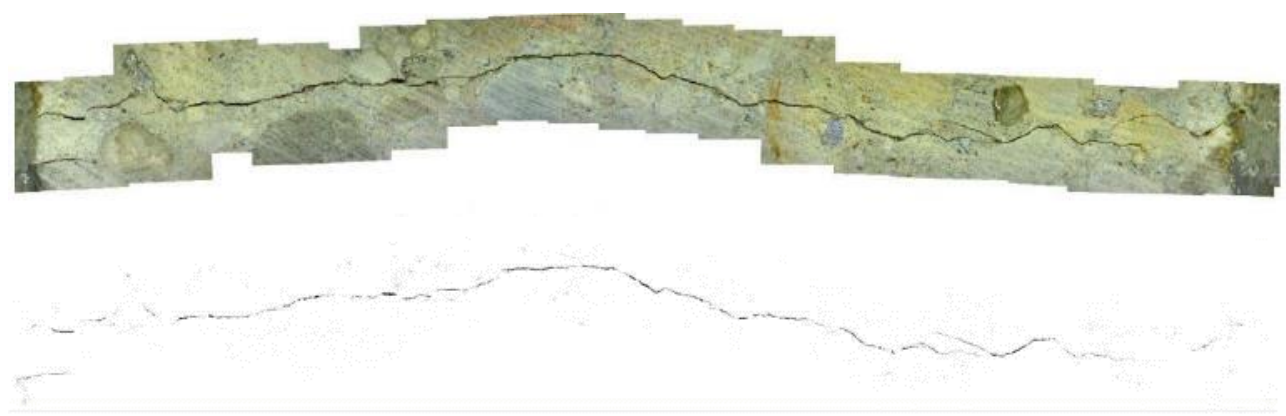

Fig. 3-6. Panorama of a top crack (top picture) and its black pixels (bottom picture).

A crack Closing Ratio parameter has been defined as follows, equation 3.1, as used for example in (Snoeck \& De Belie, 2012):

$$
\text { Closing Ratio }=1-\frac{\alpha_{\text {final }}}{\alpha_{\text {initial }}}=1-\frac{\alpha_{t}}{\alpha_{0}} \nless 0
$$

With:

$\alpha_{0}$ the initial crack parameter, either a crack width $(\mathrm{mm})$ or crack area $\left(\mathrm{mm}^{2}\right)$ measure, after precracking and before healing

$\alpha_{t}$ the final crack parameter, either a crack width $(\mathrm{mm})$ or crack area $\left(\mathrm{mm}^{2}\right)$ measure, after a healing period of $t$ days

\subsubsection{Crack closing as secondary method}

In addition to the comparison of the different methods for the evaluation of crack closing, this parameter was also evaluated as a secondary method in campaigns where the focus was made in other methodologies. The rationale is to seek for a correlation of the properties analyze due to the much easier (and non-destructive) methodology of evaluation of crack closure. 
In that case, the average crack width $\left(w_{\text {avg }}\right)$ by measuring its value at multiple fixed locations along the length of the crack, was used as the evaluation method, which is a feasible method with a short post-processing stage in the campaigns that focused on other parameters or methods.

In smaller campaigns, crack width was analyzed only at specific locations for the sake of simplicity.

\subsection{Water permeability test}

One of the main objectives of crack healing is to improve durability of concrete structures. Visual closing of cracks does not necessarily imply an improvement of durability. Therefore, permeability-based studies of self-healing are of a great importance.

There are two main groups of tests for measuring permeability of materials: for high permeability and for almost impermeable elements. Cracked concrete specimens belong to the first category, while virgin and complete healed specimens would belong to the latter.

As the main purpose is to verify the process of healing, a method based on high permeability tests is being proposed. In this way, it will not be possible to discern between different ranges inside impermeable specimens, but it would be possible to discern between different levels of crack width, to measure with a same test cracked and healed specimens and identify if the healing process has taken place.

One of the main purpose of the proposed method is to be of easy implementation in typical concrete laboratories. In Spain, standard specimens for compressive strength and permeability tests in concrete are cylinders of diameter $150 \mathrm{~mm}$ and height of $300 \mathrm{~mm}$, which is the starting point for the determination of the features of the set-up. The setup designed has similarities with the method designed by Aldea et al. (1999) because of the shape of the specimens and distribution, but using pressured water by an attached water bomb as in the method used by (Edvardsen, 1999).

\subsubsection{Precracking}

The use of cylindrical specimens limits the precracking tests to splitting test. Cylindrical specimen with dimensions of $\Phi 150 \times 300 \mathrm{~mm}$ were prepared and cut in half using a circular saw for concrete. In this way, the specimens' size for the permeability test was $\Phi 150 \times 150$ $\mathrm{mm}$.

The edge faces of each $\Phi 150 \times 150 \mathrm{~mm}$ cylinder were then polished to eliminate mortar layers (in the bottom surface in contact with the molds) and asperities (in the top free surface of the specimen as cast) by using the same circular saw. This process will allow discerning if a crack hits and breaks an aggregate or if it passes through cement paste.

The specimens were precracked by means of a splitting test (Fig. 3-7) to reach a target range of crack width, controlled by a calibration ruler. This process could be improved by using LVDTs if the purpose is to have a specific crack size. Nevertheless, in this work the purpose was to have a distribution of crack sizes inside certain range, and crack width will be measured in detail with the crack closing methods already described in Section 3.2. 
Because of that, the measure of the crack width with the calibration ruler while performing the splitting test has been meant as good enough for the purpose of this work.

Besides being an approximate way to measure the crack width, it is very simple and allows a larger number of specimens to be cracked in a reasonable time. The calibration ruler has an inherent dispersion due to the human factor but is a good method to obtain crack widths within the range of 0-0.4 mm. The amount of steel fibers used in this work allowed a good control of the cracking process, and crack width could be increased to reach certain ranges.
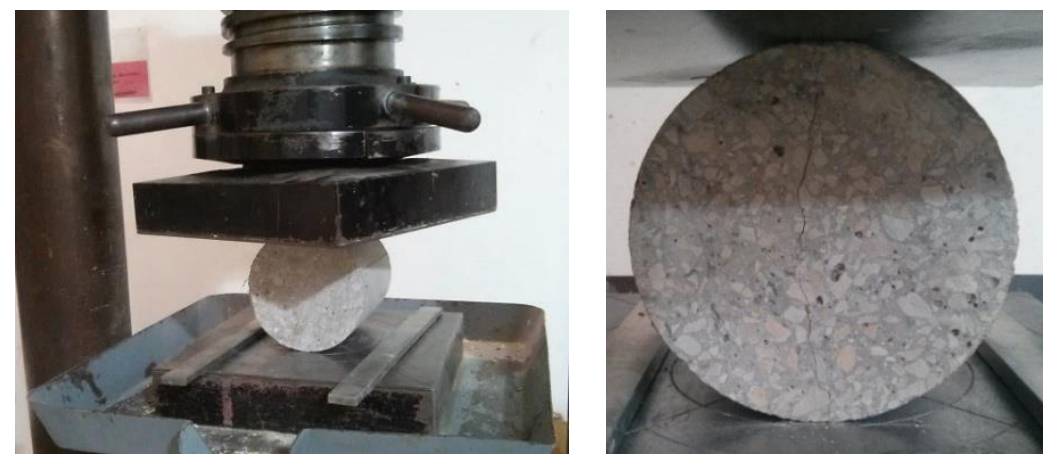

Fig. 3-7. Precracking process and precracked specimen by splitting test.

\subsubsection{Preparation of the specimens}

Once cracked, lateral cracks are sealed by using an epoxy resin (Sikadur 31-CF and 31-EF have been used in this work). A ring of the crack of one circular surface is sealed as well due to the features of the permeability test. Fig. 3-8 shows specimens with those areas already sealed. It should be noted that resin does not enter significantly inside the crack, since it is only placed externally.

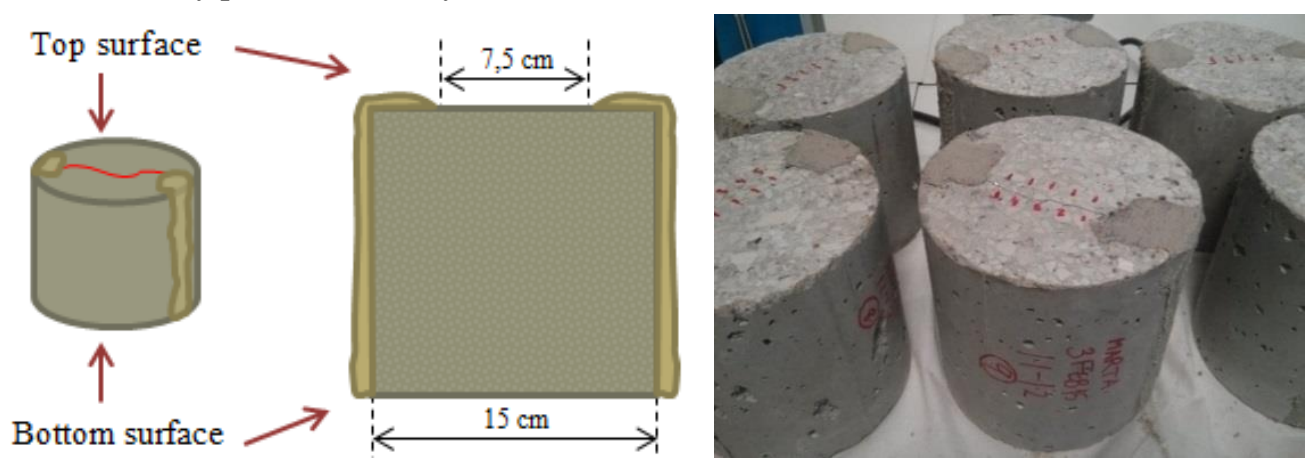

Fig. 3-8. Sealing of lateral cracks and upper ring with epoxy resin.

\subsubsection{Water permeability test on cracked concrete}

A method based on the permeability test described in UNE-EN 12390-8 was employed in this study, but measuring the water flow instead of the water depth penetration. A diagram of the test is shown in Fig. 3-9. 


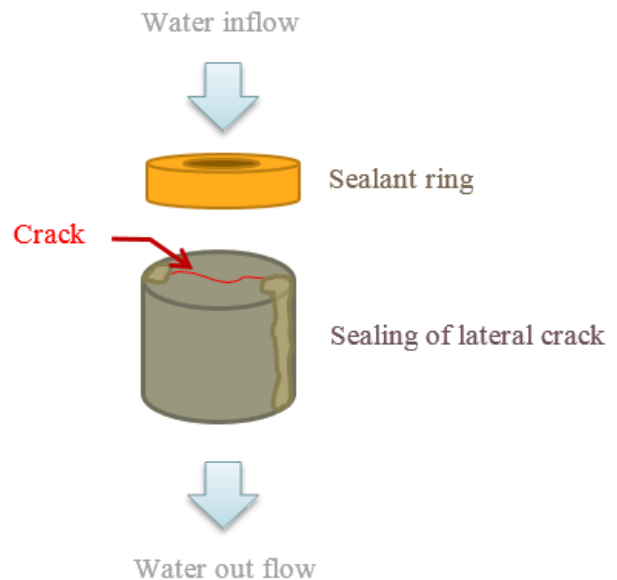

Fig. 3-9. Diagram of the permeability test for cracked specimens.

Water flow is measured by weighting the amount of water passing through the specimen in the fixed time. The recipient used for collecting water is an ordinary bucket.

The parameters of the test are:

- Head water pressure equal to 2.00 bars. In practice, the initial pressure is set equal to 2.05 bars and as pressure decreases due to water flow, the permeabilimeter turns on again when a pressure of 1.95 bars is reached, recovering the 2.05 bars pressure. Therefore, water pressure is always kept between 1.95 and 2.05 bars.

- The quantity of water passing through the crack was measured during a 5 minutes testing time for small range cracks and 1 minute for medium range cracks due to the capacity limits of the recipients.

Using high values of water pressure will force water to pass through the crack in short time, presumably reducing the effects of the sinuosity of the in-depth crack and to avoid the bubble effect reported by Ikoma, et al. (2015).

Following this method, water passes through the interior of the specimen by the crack and it was experimentally confirmed that, as it was expected, small cracks had smaller water flow while larger cracks presented higher water flows. In this way, if a crack closes after the healing process, the water flow should have diminished. The permeabilimeter used in the test and the different parts it consists of it are shown in Fig. 3-10.

The effect of healing on permeability can be evaluated by calculating a Healing Ratio parameter analogously to the Closing Ratio as per equation 3.2:

$$
\text { Healing Ratio }=1-\frac{\text { Final Flow }}{\text { Initial Flow }}=1-\frac{Q_{t}}{Q_{0}} \nless 0
$$

where:

$Q_{0}$ the initial water flow $(\mathrm{ml} / 5 \mathrm{~min})$, measured after precracking

$Q_{t}$ the final water flow ( $\mathrm{ml} / 5 \mathrm{~min}$ ), measured after a healing period of $t$ days 
After the healing process, cracked specimens that were stored in water immersion were completely saturated. Because of that, before performing the final permeability test, specimens were left drying in the laboratory for two hours to allow the exit of the water from the crack and to avoid handling specimens with a slipping surface.

When performing photos of the cracks for the evaluation of crack closing, they were always taken after performing the water permeability test.
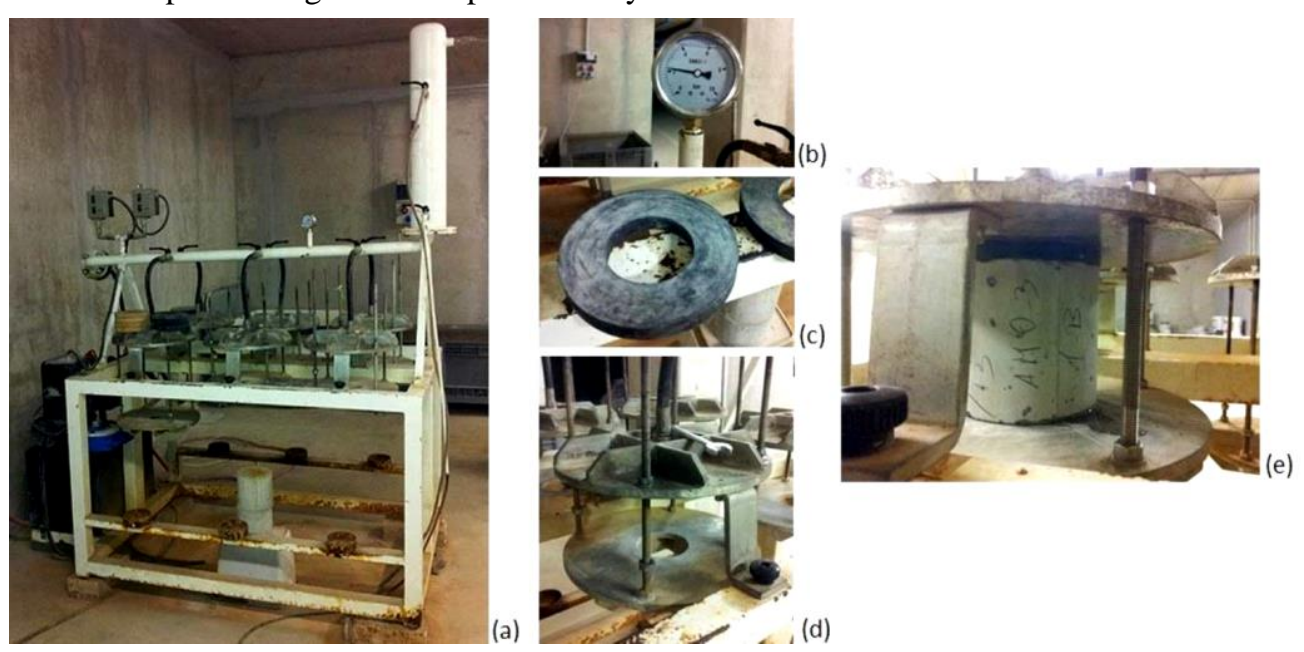

Fig. 3-10. Permeabilimeter (a) and its parts: manometer (b), sealing ring (c), auxiliary structure (d), prepared specimen $(e)$.

\subsection{Mechanical properties}

In general, it is considered that a complete self-healing would be able to recover its pristine mechanical properties, even if only partially recovered. In the literature, different tests have been proposed to evaluate the self-healing capability of concrete caused by the recovery of its mechanical properties. Also, different criteria have been considered, such as direct comparison between the initial and final properties of the same specimen (Snoeck \& De Belie, 2015), using in the evaluation also the residual values at unloading (Van Tittelboom et al., 2012; Ferrara et al., 2014), or introducing accompanying specimens that heal in a reference exposure or accompanying specimens that are precracked and reloaded at the final age, either stored at a reference exposure (Granger et al., 2007) or stored in the same exposure as the analyzed specimens (Schlangen et al., 2006). Fig. 3-11 summarizes the types of references that can be used when evaluating the mechanical recovery. 
1. Direct comparison

2. Using a reference parameter of the same curve
a) Precracking
b) Unloading (tangent or secant)
c) Reloading

3. Using a reference parameter from accompanying specimen

\section{Cured at the same exposure \\ II. Cured at a reference exposure}

Fig. 3-11. Diagram with a classification of the different reference possible parameters.

In general, the expressions to calculate the mechanical recovery follow the structures from equations 3.3 and 3.4, with slight variations depending on the study and its specific purpose. These expressions are valid either for tensile, flexural or compressive strength, being flexural tests the most frequently used in the literature.

$$
\begin{gathered}
\text { Recovery } 1=\frac{\text { Healed }}{\text { Precrack }} \\
\text { Recovery } 2=\frac{\text { Healed-reference }}{\text { Precrack-reference }}
\end{gathered}
$$

Since concrete properties are time-dependent, to discern the healing effect of maturing, the properties after healing cannot be directly compared with the properties of the precracking curve. Comparing final and initial properties allows to evaluate to which exent the pristine strength has been recovered in a determined specimen, but does not take into consideration the increase of strength with the age. In the case of using reference accompanying specimens, the strength increase with the age is considered, but it adds the deviation of comparing two different specimens.

Healing would ideally produce a new peak in the reloading load-displacement curve and an increase in the stiffness of the reloading curve, as reported in the results by Granger et al. (2007) explained in Chapter 2 (see Fig. 2-31). The filling of the crack with a material of enough strength and strong enough bond to the old concrete cracked matrix, would produce: 1) the presence of a new peak in the load-displacement curves, and 2) higher stiffness compared with the samples without healing. However, this second feature, may also occur when the adherence between the reinforcement (e.g. fibers) is improved by the maturing processes.

Diagrams in Fig. 3-12 show details of the different curves the denomination of the parameters that will be used in the equations for the self-healing expressions. 

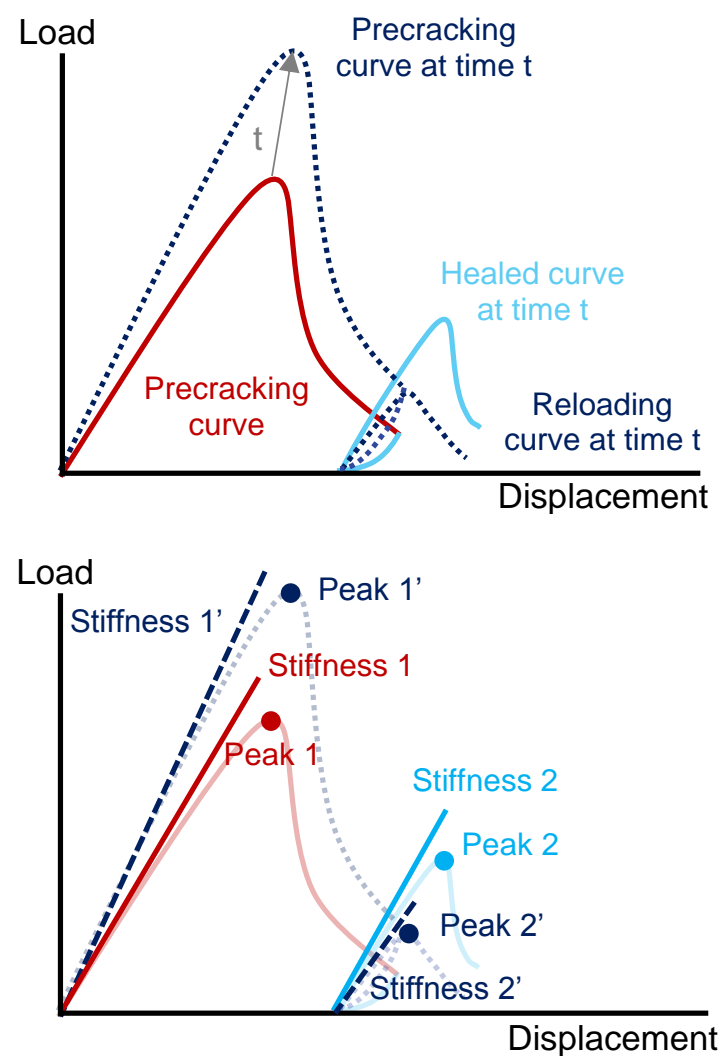

Fig. 3-12. Diagram with the parameters of interest for the evaluation of self-healing.

Different scenarios can be considered concerning the extent of mechanical recovery achieved (see also Fig. 3-13):

- Best-case scenario 1: the reloading curve of the healed specimen at time $t$ has comparable properties to those of the uncracked accompanying specimen (precracking curve at time $\mathrm{t}$ ). This is the most ideal situation, since the specimen is able to compensate the damage and reach the strength it should have had if the damage had not been produced.

- Best-case scenario 2: the reloading curve of the healed specimen at time $t$ has comparable properties to its initial precracking curve. This is a less exigent but still an ideal situation, where the specimen is able to recover its pristine properties.

- Worst-case scenario: the reloading curve follows the same trend as its own precracking curve, showing that no strength was recovered, and also the adquisition of strength or maturing was stopped, diminished or compensated by degradation processes.

- Intermediate scenarios: the reloading curve shows slight improvements compared to the one in the worst-case scenario, indicating some strength adquisition after the 
damaging process, which can be caused by the maturing process of concrete by continuing hydration or by healing.

\section{Best-case (properties at time $t$ )}

Load

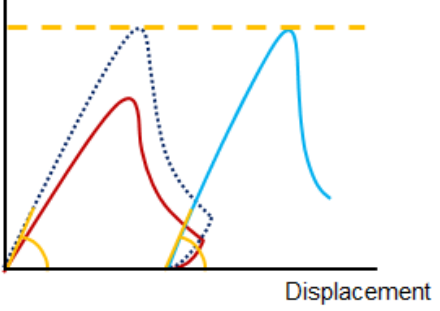

Best-case (original properties)

Load

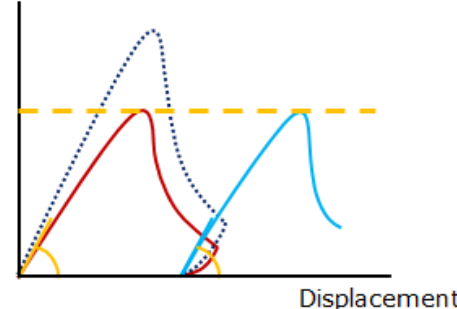

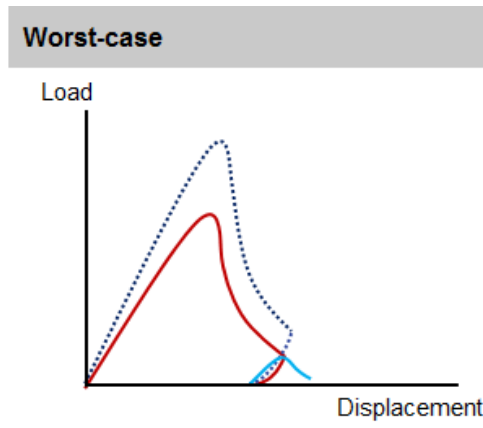

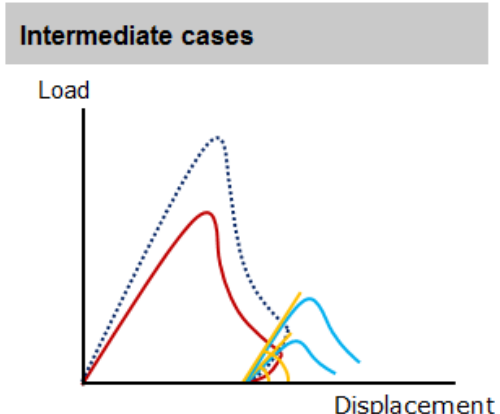

Intermediate cases

Load

Displacement

- Precracking curve at time t

... Precracking curve at time $t+h$

Healed curve at time $t+h$

Fig. 3-13. Diagrams with the different possible scenarios regarding mechanical recovery.

In general, the scenario of interest will correspond with the intermediate cases, and autogenous healing will lack a new peak in the reloading curve, with the recoveries mainly detected as stiffness variations. This is supported by the results of the majority of the works reported in the literature. Most studies related with autogenous healing did not found peak recoveries, with some studies reporting recoveries of both peak load an stiffness (Granger et al., 2007), but this was mainly when using other healing products, such as bacteria or adhesives stored in fragile tubes located in specific sections (Van Tittelboom et al., 2011) (Wang et al., 2012).

The three point bending flexural test presented in this work is the flexural test from EN14651 modified for prismatic specimens $100 \mathrm{~mm} \times 100 \mathrm{~mm} \times 500 \mathrm{~mm}$, in order to adapt the parameters to the smaller size of the specimen. Notched specimens were used in order to have the crack located in the middle of the specimen (see Fig. 3-14). Crack opening during the test was measured with a transparent calibration ruler or with attached LVDTs. 
Chapter 3. Selection and development of the experimental methods

Load and vertical displacement were recorded with the Instron machine used for the test. The self-healing properties will be evaluated in peak load, stiffness, and/or energy terms.
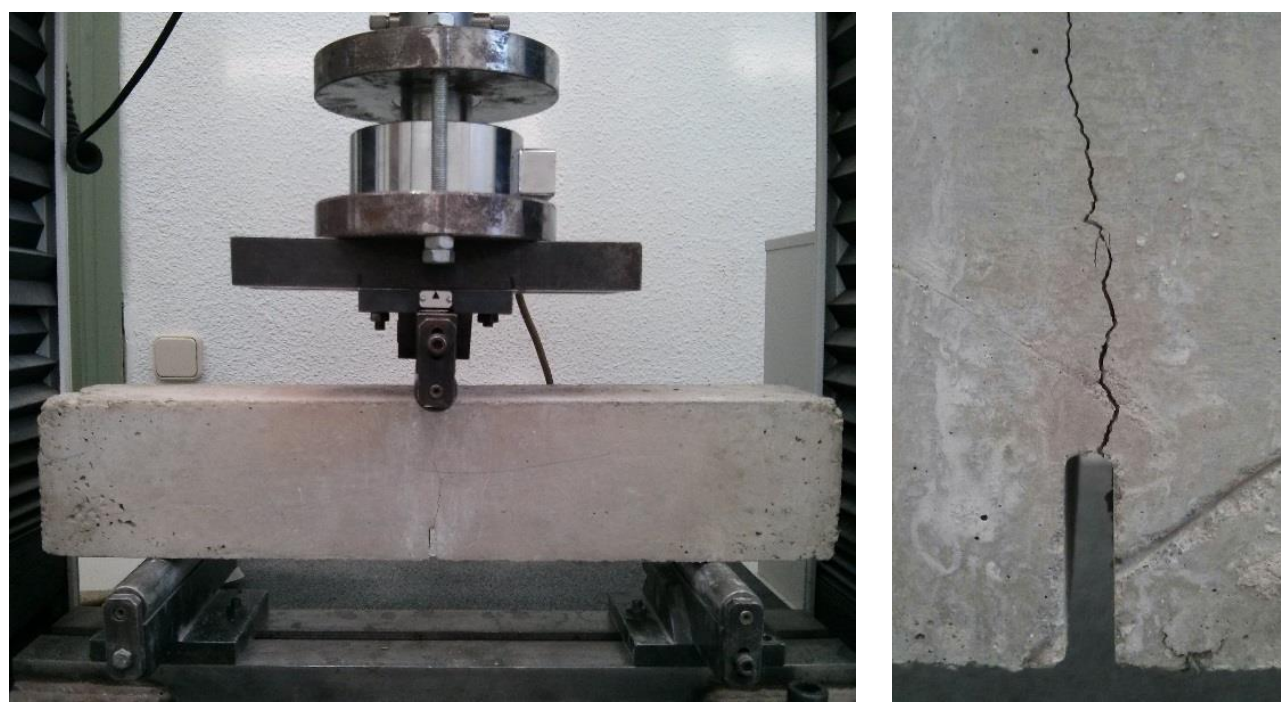

Fig. 3-14. Setup for the three point bending test (left) and detail of the notch and a crack (right)

\subsubsection{Healed specimens compared with themselves before healing}

This methodology compares the results of a same specimen before and after the healing stage. A diagram showing the process followed by the specimens is displayed in Fig. 3-15.

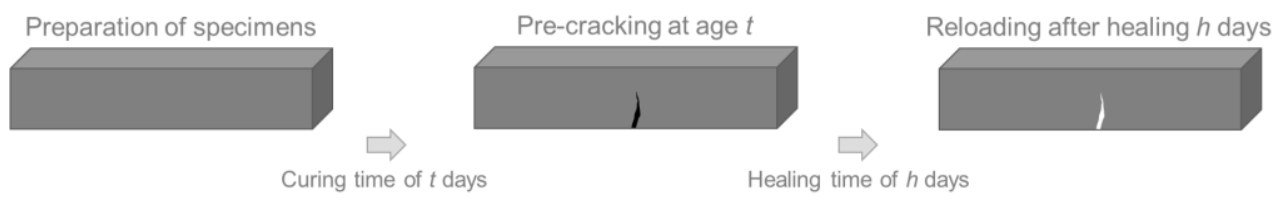

Fig. 3-15. Testing procedure for concrete specimens.

\subsubsection{Peak load and maximum strength}

Following the parameters in Fig. 3-12, when using a same specimen before and after healing, the parameters of interest are:

- Peak load at precracking $\left(\mathrm{P}_{1}\right)$, at $\mathrm{t}$ days.

- Residual strength $\left(\mathrm{P}_{\mathrm{u}}\right)$, in the precracking curve at the moment of unloading, at $\mathrm{t}$ days

- Peak load at reloading $\left(\mathrm{P}_{2}\right)$, value after $\mathrm{h}$ days of healing.

And the following equations can express the regain in peak load.

$$
\begin{gathered}
\text { Peak load recovery } 1=\frac{P_{\text {reloading }}}{P_{\text {precracking }}}=\frac{P_{2}}{P_{1}} \\
\text { Peak load recovery } 2=\frac{P_{\text {reloading }}-P_{\text {residual }}}{P_{\text {precracking }}-P_{\text {residual }}}=\frac{P_{2}-P_{u}}{P_{1}-P_{u}}
\end{gathered}
$$


Depending on the fibers amount the specimen may not display a clear peak in the loaddisplacement curves. In those cases, the maximum load can also be used as a parameter.

\subsubsection{Stiffness}

Fig. 3-16 and Fig. 3-17 show an example using real curves of load-displacement curves for precracking (before healing) and reloading (after healing) and shows the parameters of interest related to the stiffness from these curves, which are:

- Loading slope $\left(\mathrm{K}_{1}\right)$, in the precracking curve, which indicates the stiffness at $\mathrm{t}$ days.

- Unloading secant slope $\left(\mathrm{K}_{\mathrm{us}}\right)$ in the precracking curve, at $\mathrm{t}$ days

- Unloading tangent slope $\left(\mathrm{K}_{\mathrm{ut}}\right)$ in the precracking curve, at t days

- Reloading slope $\left(\mathrm{K}_{2}\right)$, which indicates the stiffness after h days of healing.

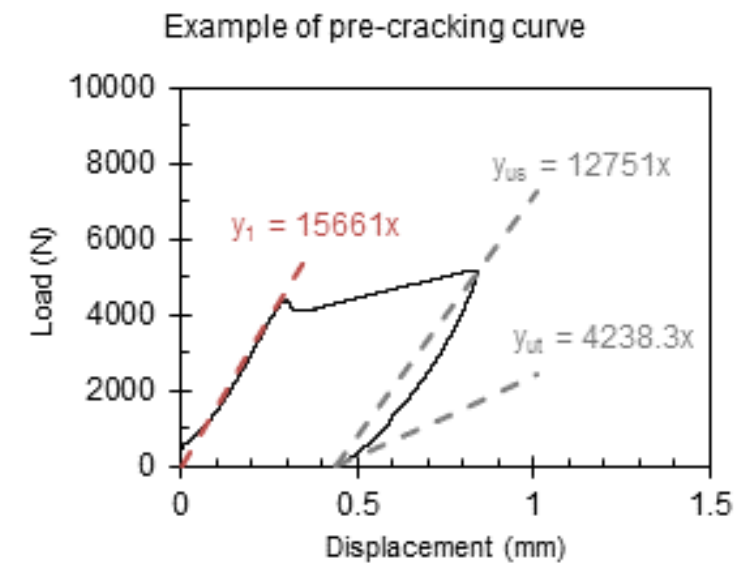

Fig. 3-16. Example of three point bending test of a specimen at precracking.

\section{Example of re-loading curve}

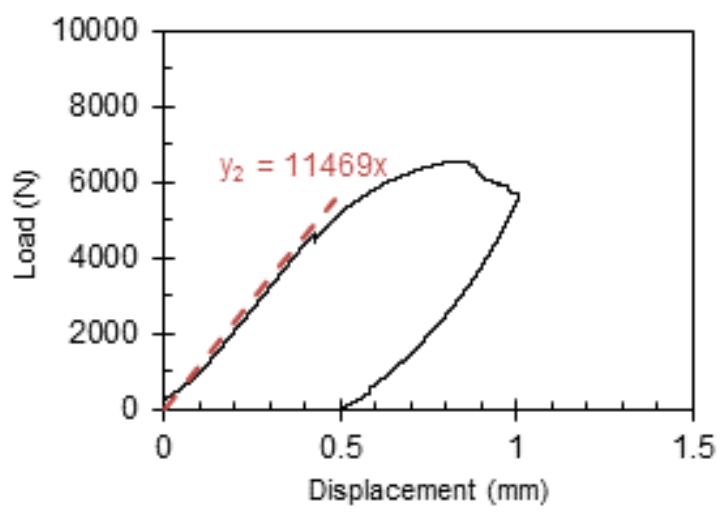

Fig. 3-17. Example of three point bending test of a specimen at precracking (top) and reloading after healing (bottom). 
Chapter 3. Selection and development of the experimental methods

The recovery of stiffness can be evaluated using several expressions:

$$
\begin{gathered}
\text { Stiffness Recovery }(\%)=\frac{\text { Re-loading stiffness }}{\text { Pre-cracking stiffness }}=\frac{K_{2}}{K_{1}} \\
\text { Stiffness Healing Secant }=\frac{\text { Re-loading stiffness-Unloading,Secant }}{\text { Pre-cracking stiffness-Unloading,Secant }}=\frac{K_{2}-K_{u s}}{K_{1}-K_{u s}} \\
\text { Stiffness Healing Tangent }=\frac{\text { Re-loading stiffness-Unloading,Tangent }}{\text { Pre-cracking stiffness-Unloading,Tangent }}=\frac{K_{2}-K_{u t}}{K_{1}-K_{u t}}
\end{gathered}
$$

The value of loading slopes for the stiffness can be evaluated using a linear regression between the 40 and $70 \%$ of the Peak Load as indicated in Fig. 3-18.

Range to calculate slope

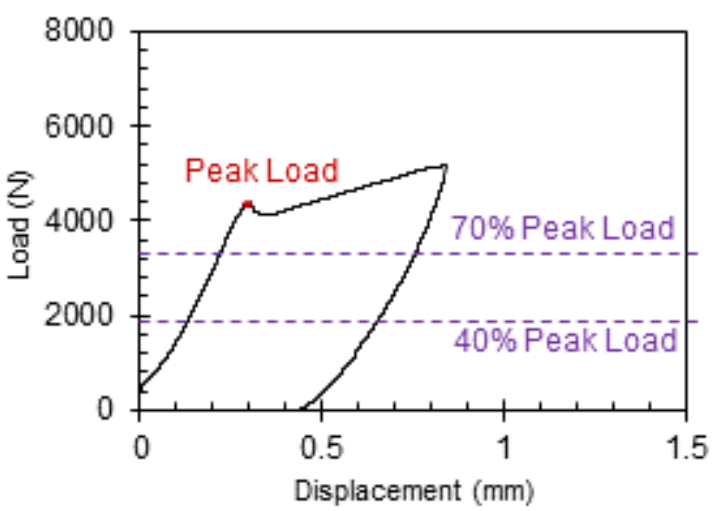

Fig. 3-18. Example load ranges for the calculation of the regression line for the stiffness.

For the calculation of the unloading slope tangent to the point where the curve hits the horizontal axis, the procedure followed in this work is: first to calculate the second-degree curve that fits the unloading slope (R-squared values obtained are all close to 1, with values generally of $\sim 0.999$ ), and then the derivate equation of the $2^{\text {nd }}$ degree curve is calculated to achieve the tangent slope.

\subsubsection{Energy}

An additional evaluation in terms of energy is proposed, by using the area under the loaddisplacement curve. Each curve was loaded approximately until achieving certain crack opening, but this leads to different maximum values of displacement for each curve (even though they are in a close range). To overcome this difficulty, for each specimen, the area can be evaluated until the smaller between the maximum displacement from the precracking curve and the maximum displacement from the reloading curve.

$$
\text { Regain of Energy }(\%)=\frac{\text { Re-loading area }}{\text { Pre-cracking area }}
$$

In all cases the first part of the area has not been considered since it is produced by the adjustment of the specimen and the three point bending testing machine and do not represent the mechanical properties of the specimen. 


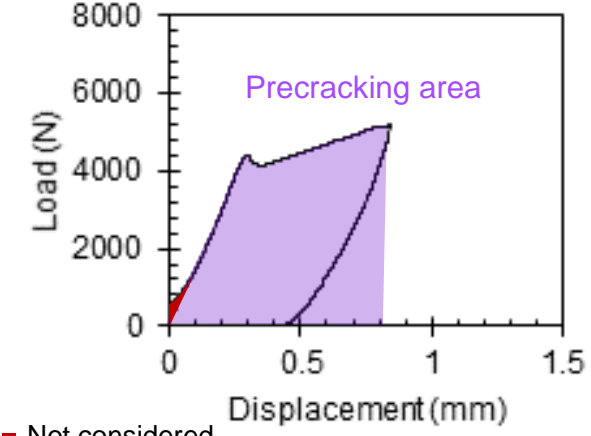

- Not considered

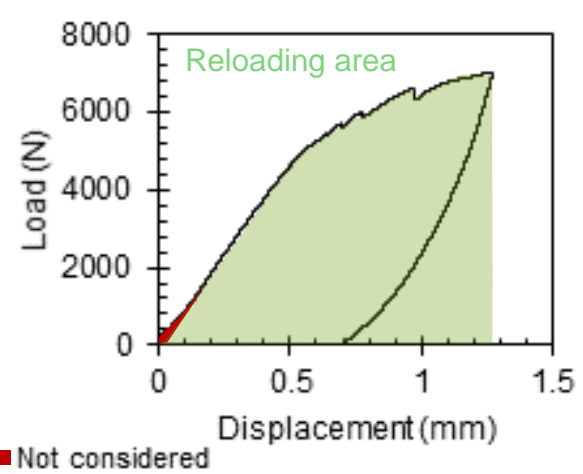

- Not considered

Fig. 3-19. Example of evaluation of the regain of energy.

\subsubsection{Healed specimens compared with accompanying specimens}

In this case, additional specimens to the main specimens (damaged and healed) are casted in order to have references not from the same specimen before healing, but from a different specimen representing their properties at the time of the end of the healing process.

As in the previous method, the parameters used for the comparison will be the peak load stiffness and energy of the specimens. The accompanying specimen can undergo the same conditioning and ageing story than the precracked and healed specimens (Fig. 3-20), or can be stored at a reference exposure without healing (such as humidity chamber conditions).

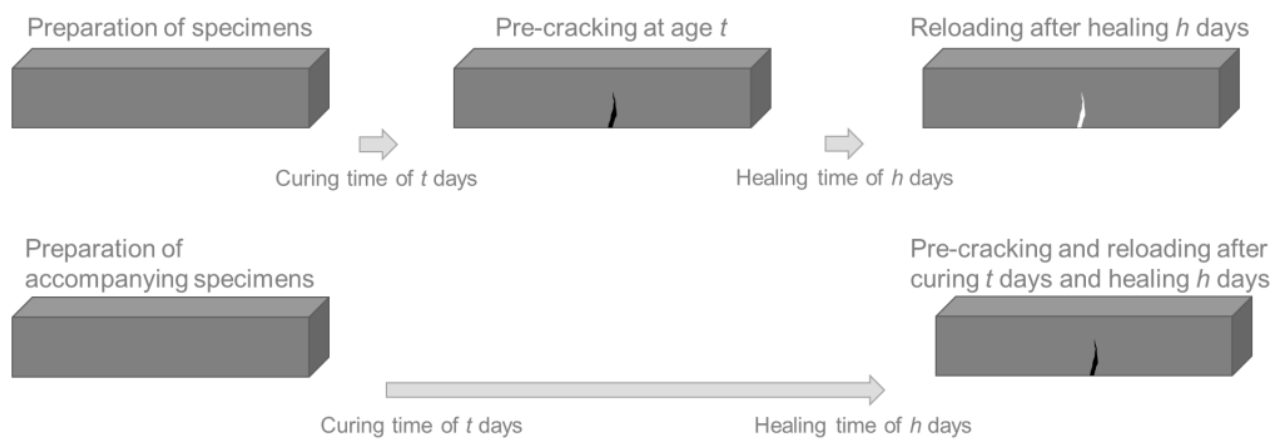

Fig. 3-20. Testing procedure for concrete and accompanying specimens.

\subsubsection{Peak load and maximum strength}

Following the parameters in Fig. 3-12, when using a same specimen before and after healing, the parameters of interest are:

- Peak load at reloading the healed specimen $\left(\mathrm{P}_{2}\right)$, value after $\mathrm{h}$ days of healing.

- Peak load at reloading the accompanying specimen $\left(\mathrm{P}_{2}{ }^{\prime}\right)$, value after $\mathrm{h}$ days of healing.

- Residual strength $\left(\mathrm{P}_{\mathrm{u}}\right)$, in the precracking curve at the moment of unloading, at $\mathrm{t}$ days

And the following equations can express the regain in peak load. 


$$
\begin{gathered}
\text { Peak load recovery } 1=\frac{P_{\text {reloading }}}{P_{\text {reloading }}}=\frac{P_{2}}{P_{2 \prime}} \\
\text { Peak load recovery } 2=\frac{P_{\text {reloading }}-P_{\text {residual }}}{P_{\text {reloading }}-P_{\text {residual }}}=\frac{P_{2}-P_{u}}{P_{2 \prime}-P_{u}}
\end{gathered}
$$

Depending on the fibers amount the specimen may not display a clear peak in the loaddisplacement curves. In those cases, the maximum load can also be used as a parameter.

\subsubsection{Stiffness}

Analogously to the previous case. the parameters of interest related to the stiffness from these curves are:

- Reloading slope in the healed specimen $\left(\mathrm{K}_{2}\right)$, which indicates the stiffness after $\mathrm{h}$ days of healing.

- Reloading slope in the accompanying specimen $\left(\mathrm{K}_{2}{ }^{\prime}\right)$, which indicates the stiffness after $\mathrm{h}$ days of healing.

- Unloading secant slope $\left(\mathrm{K}_{\mathrm{us}}\right)$ in the precracking curve, at $\mathrm{t}$ days

- Unloading tangent slope $\left(\mathrm{K}_{\mathrm{ut}}\right)$ in the precracking curve, at $\mathrm{t}$ days

- Reloading slope $\left(\mathrm{K}_{2}\right)$, which indicates the stiffness after h days of healing.

The recovery of stiffness can be evaluated using the expressions:

$$
\begin{gathered}
\text { Stiffness Recovery }(\%)=\frac{\text { Re-loading stiffness }}{\text { Re-loading stiffness }{ }^{\prime}}=\frac{K_{2}}{K_{2 \prime}} \\
\text { Stiffness Healing Secant }=\frac{\text { Re-loading stiffness-Unloading,Secant }}{\text { Re-loading stiffness } 1 \text {-Unloading,Secant }}=\frac{K_{2}-K_{u s}}{K_{2 \prime}-K_{u s}} \\
\text { Stiffness Healing Tangent }=\frac{\text { Re-loading stiffness-Unloading,Tangent }}{\text { Re-loading stiffness } 1 \text {-Unloading,Tangent }}=\frac{K_{2}-K_{u t}}{K_{2 \prime}-K_{u t}}
\end{gathered}
$$

\subsection{Sorptivity test}

Cracks in concrete are a potential entrance for aggressive agents that may initiate different degradation processes. The appearance of such small cracks would potentially increase permeability, but also sorption, which can accelerate degradation processes. Water absorption tests measure water flow produced in the pores and capillaries, and the sorptivity is an index that can be calculated from the capillary water suction test. The sorptivity method described in this section for mortar specimens has been used in works by (Alghamri et al., 2016; Giannaros et al., 2016), but is explained in this chapter for the sake of clarity and to explain the modifications to isolate the sorptivity of the crack using accompanying specimens.

\subsubsection{Precracking}

Three point bending test is used as the precracking method. A notch is necessary before the precracking stage to force the crack to be in the central section of the mortar specimen. An Instron clip gauge was attached to the edges to register displacement at crack mouth opening (CMOD). Steel edges were glued with structural epoxy at a distance of $4 \mathrm{~cm}$. A 
plastic/rubber band was used between the load applier accessory and the specimen to minimize the interferences of surface irregularities. The load rate used is $0.25 \mathrm{~mm} / \mathrm{min}$. Fig. 3-21 shows the steel edges (left) and the setup during for the precracking stage.
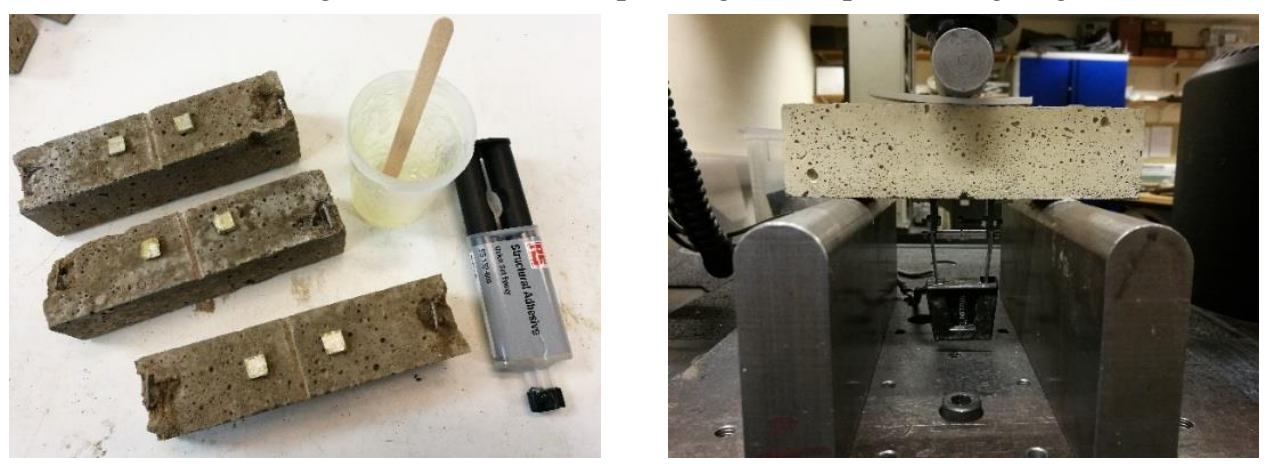

Fig. 3-21. Cleaning steel plates (left) and attachement in the specimens (right).

\subsubsection{Sorptivity test}

Sorptivity has been measured in reference uncracked specimens in addition to the cracked and healed specimens. This will permit to normalize the results and distinguish hardening effects from healing of the crack. Reference specimens need to be uncracked to differentiate the sorption due to hardening from healing.

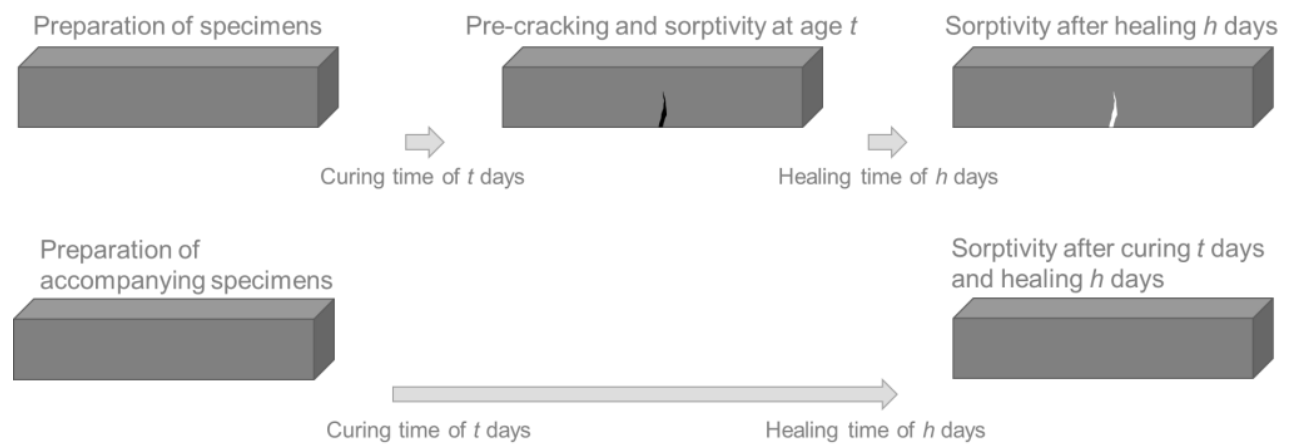

Fig. 3-22. Testing procedure for concrete and reference specimens.

For the sorptivity test, mortar specimens must be covered with an aluminum tape, to ensure sorption of water only through the notch and the crack (Fig. 3-23 left). Then all specimens are placed in a recipient with water. Only one surface of the specimen with dimension of $40 \times 160 \mathrm{~mm}$ was allowed to be in contact with water, with the depth of water of around 1-2 $\mathrm{mm}$, never touching the bottom part of the notch.

Water uptake is measured by weighing the specimen in increasing times during 4 hours and 16 minutes. Each measure (n) is performed at the corresponding minutes following the quadratic sequence $(\mathrm{n})^{2}: 0,1,4,9,16,25,36,49,64,81,100,121,144,169,196,225$ and 256. After 6 hours, the rate of absorption decreases (Martys \& Ferraris, 1997), and thus, 4 
Chapter 3. Selection and development of the experimental methods

hours were considered enough for the purpose of the study. Before each measure the specimen is carefully dried in a tissue to remove the excess of water.
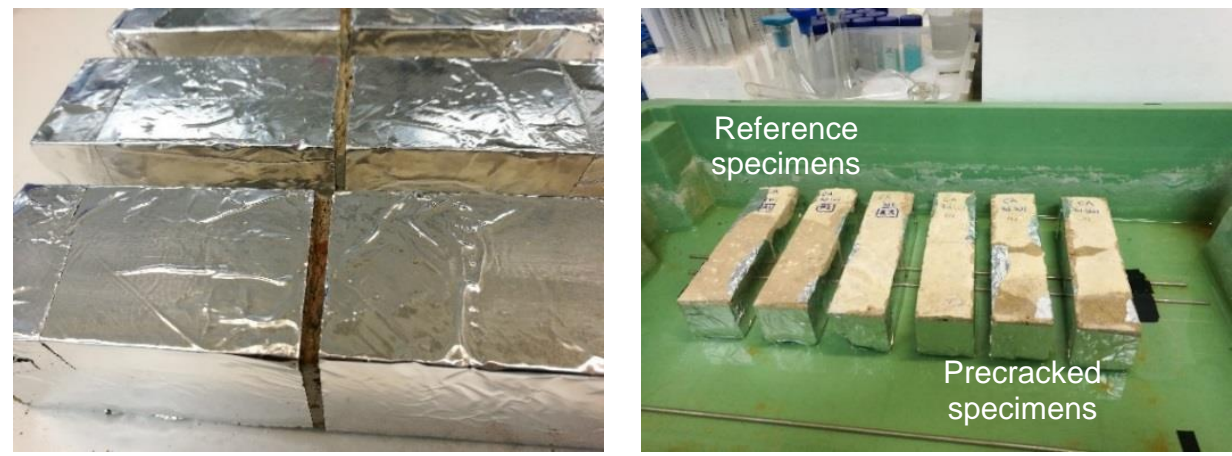

Fig. 3-23. Aluminum tape covering specimens except the crack area (left) and sorptivity test of reference and precracked specimens (right).

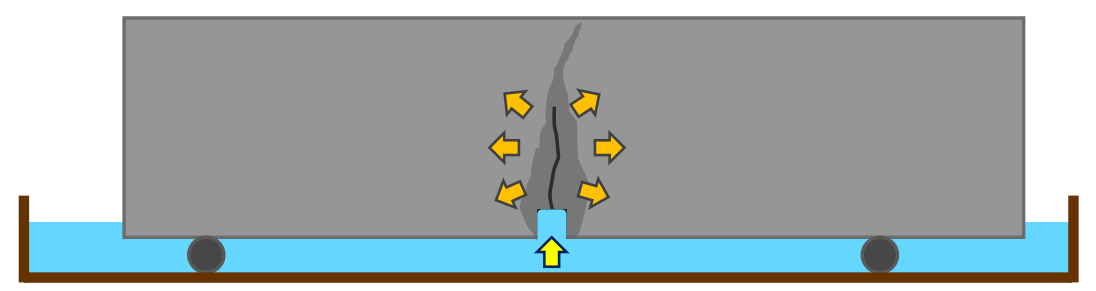

Fig. 3-24. Diagram of the water suction during the sorptivity test.

Prior to performing the sorptivity test on healed specimens, these specimens were left conditioning in the laboratory for one day. Uncracked specimens will serve as the reference, and the results of precracked specimens will be normalized using their values. This will eliminate any variation on water sorption caused by the storing in different healing conditions and their internal humidity. Drying in an oven was discarded in this study to not damage the internal precipitate formation and diminish the handling processes that may also alter the precipitates inside the cracks.

\section{Uncracked-before healing}

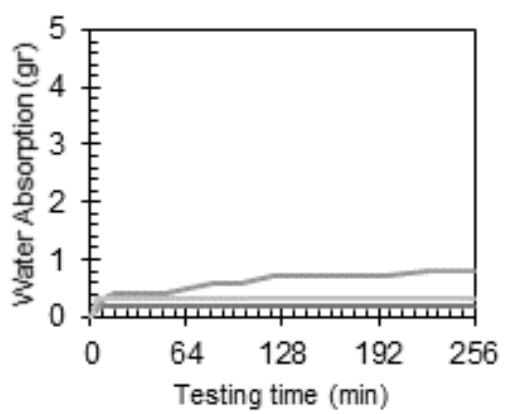

Precracked - before healing

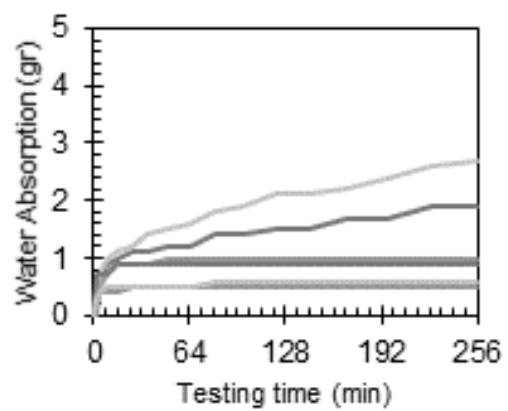

Fig. 3-25. Example of water absorption curves, uncracked (left) and precracked (right) specimens before healing. 
The cumulative absorbed volume $i(\mathrm{~mm})$, is calculated as the change in mass $(\mathrm{g})$ divided by the cross-sectional area of the test specimen $\left(\mathrm{mm}^{2}\right)$ and the density of water at the recorded temperature $\left(\mathrm{g} / \mathrm{mm}^{3}\right)$. The cumulative absorbed volume is plotted against square root of time, $\sqrt{t}\left(\min ^{1 / 2}\right)$ and Sorptivity index is calculated as the slope of the linear regression of the curves, between $i$ and $\sqrt{t}$, as per ASTM C1585-13 (see Fig. 3-26):

$$
i(\mathrm{~mm})=\frac{M_{t}(\mathrm{gr})-M_{0}(\mathrm{gr})}{\rho_{\text {water }}\left(\frac{\mathrm{gr}}{\mathrm{mm}^{3}}\right) * \operatorname{Area}_{\text {notch }}\left(\mathrm{mm}^{2}\right)}=\frac{M_{t}-M_{0}}{0.000998 *(5 * 40)}
$$

The linear regression is calculated between the points 1 and 16 , that means that the initial point at time 0 , which will have an infiltration value of 0 (mass at time $t$ is equal to its initial mass), is not considered in the regression.

Uncracked - before healing

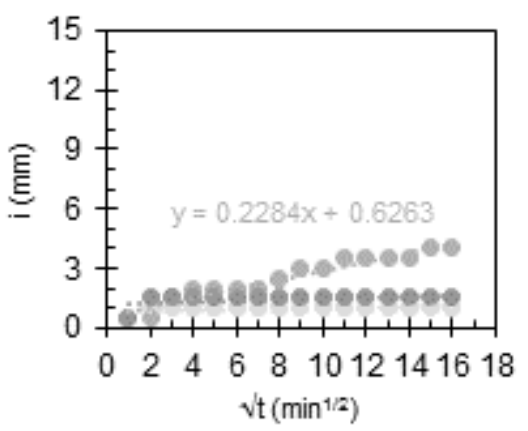

\section{Precracked-before healing}

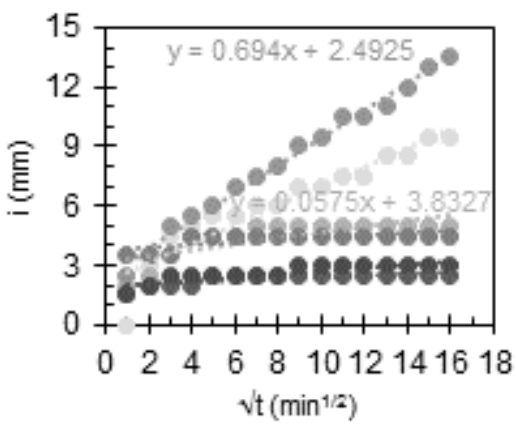

Fig. 3-26. Cumulative absorbed volume vs. square root of time.

To remove the influence of the ambient state of each group and compare between groups, it is proposed to differentiate between sorption through the notch area and sorption through the crack, by calculating the sorptivity contribution by the crack as follows:

$$
S_{\text {crack }}=S_{\text {precracked specimen }}-S_{\text {uncracked specimen }}
$$

Where $S_{\text {precracked specimen }}$ is the sorptivity value of a cracked specimen after healing, and as

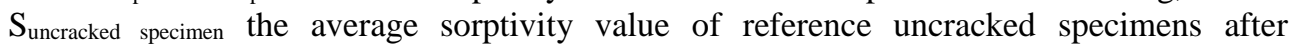
conditioning. This can be used to evaluate damage level, using values before healing; and to evaluate the healing capability of a specimen.

An additional parameter that can be calculated is the Initial Rate of Suction (IRS), as in the BS 3921 for masonry units, which uses the sorption in the first minute, according to:

$$
\begin{gathered}
i(\mathrm{~mm})=\frac{M_{1}(\mathrm{gr})-M_{0}(\mathrm{gr})}{\rho_{\text {water }}\left(\frac{\mathrm{gr}}{\mathrm{mm}^{3}}\right) * \operatorname{Area}_{\text {notch }}\left(\mathrm{mm}^{2}\right)}=\frac{M_{1}-M_{0}}{0.000998 *(5 * 40)} \\
\operatorname{IRS}\left(\mathrm{mm} * \min ^{1 / 2}\right)=\frac{i(\mathrm{~mm})}{\sqrt{t(\mathrm{~min})}}
\end{gathered}
$$

Since $\sqrt{ } 1=1$, this value of sorptivity obtained after $1 \mathrm{~min}$ will be directly equal to the IRS. 


\subsection{Characterization of concrete and mortars}

Characterization tests were performed to concrete and mortar batches for two purposes: 1) verifying the homogeneity of specimens of different batches with the same mixture proportions, and 2) comparing the results when adding the crystalline admixture type A, (which is the most used in this work), types B and C, used only in specific experimental campaigns. These characterization tests include workability and compressive strength tests. In addition, a specific study analyzes the effects produced in cement hydration by the addition of several dosages of two different CA: type A and type D, in order to contribute to the existing knowledge about the CA.

\subsubsection{Workability and compressive strength of concrete}

For each batch, three $\Phi 150 \times 300 \mathrm{~mm}$ cylindrical specimens were cast according to UNEEN 12390-2 to determine the compressive strength at 28 days, as per UNE EN 12390-3. All batches were also characterized by their workability with slump test as per UNE EN 123502:2009 (Fig. 3-27). These control tests were performed with the objective of verifying the homogeneity of specimens of different batches but belonging to a same mix group (either control or $\mathrm{CA}$ ) and to compare the results between the two mix groups (control and $\mathrm{CA}$ ).
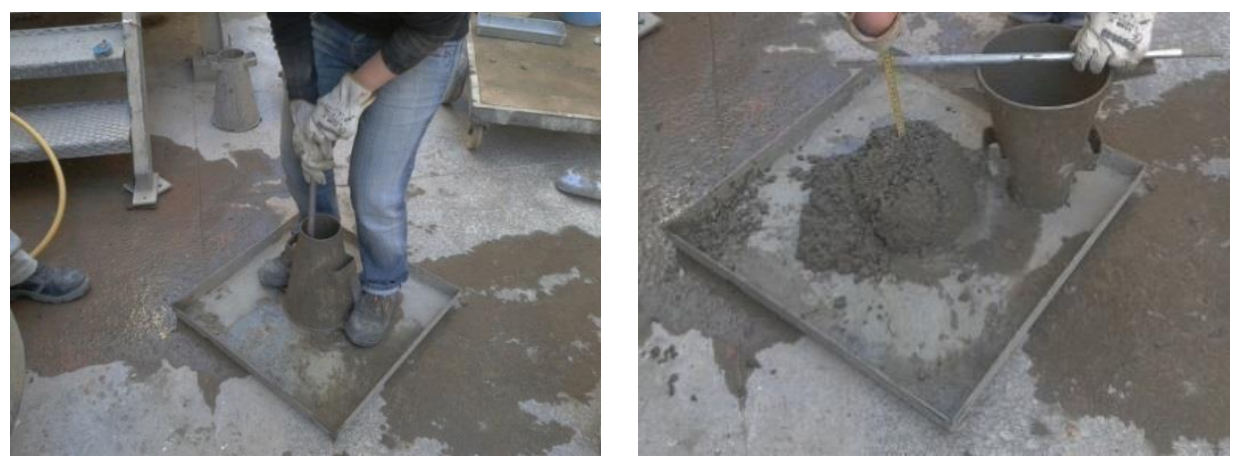

Fig. 3-27 - Slump test following UNE EN 12350-2:2009.

After averaging the results of all batches for each group (see Fig. 3-28 and Table 3-4), it was observed that concrete with $4 \%$ of CA type A by cement weight had a significantly better compressive strength, about $15 \%$ higher than control concrete in the case of water/cement ratio of 0.45 and $8 \%$ higher for the group with water/cement ratio of 0.60 .

With reference to the slump test results, differences are slightly lower, since the average results are around 13-16 cm for the four groups, which are within the acceptable tolerance limits of slump tests according to the standards.

Other mixture proportions used punctually in this work, had the same base mixture but with slight variations of the amount of fibers. Their results are not included in this subsection, since their properties are almost the same: compressive strength was comparable, and slump was only slightly reduced when increasing the amount of fibers. These properties are included in the subsections where they are used, in the tables that display the mixture proportions. 


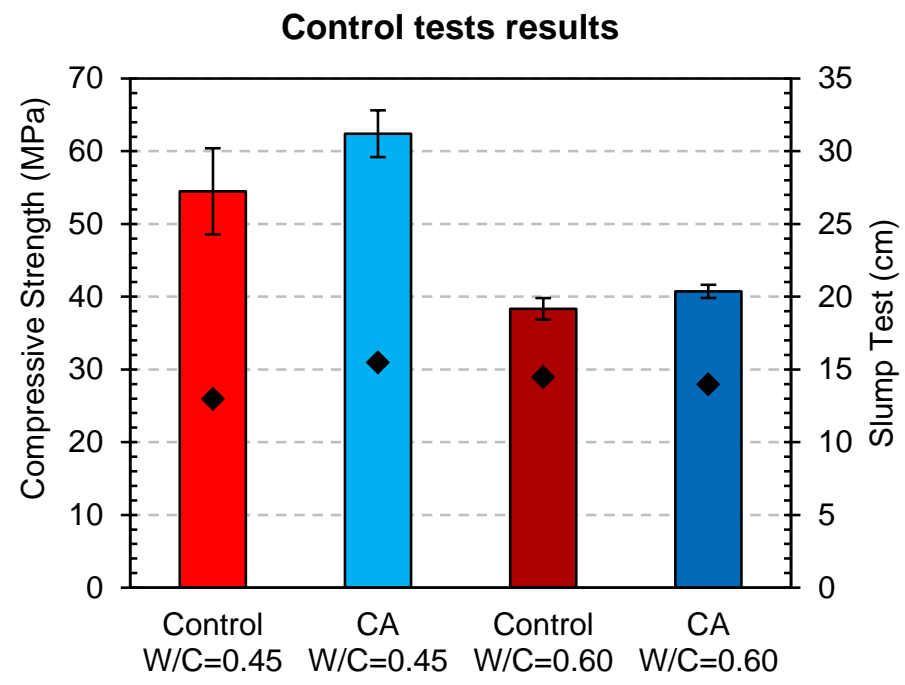

Fig. 3-28. Avg. compressive strength (bars) and slump (diamonds) with and without $4 \%$ of CA type A.

\begin{tabular}{cccccc}
\hline w/c & Mix & $\begin{array}{c}\text { Slump } \\
\text { Test } \\
(\mathbf{c m})\end{array}$ & $\begin{array}{c}\text { Slump Test } \\
\text { Deviation } \\
(\mathbf{c m})\end{array}$ & $\begin{array}{c}\text { Average } \\
\text { Compression } \\
\text { Strength } \\
(\mathbf{M P a})\end{array}$ & $\begin{array}{c}\text { Deviation } \\
\text { Compression } \\
\text { Strength } \\
(\mathbf{M P a})\end{array}$ \\
\hline \multirow{2}{*}{$\mathbf{0 . 4 5}$} & Control & 13.00 & 3.61 & 54.49 & 5.92 \\
\cline { 2 - 6 } & $4 \%$ CA type A & 15.50 & 1.73 & 62.41 & 3.22 \\
\hline \multirow{2}{*}{$\mathbf{0 . 6 0}$} & Control & 14.50 & 0.71 & 38.33 & 1.48 \\
\cline { 2 - 6 } & $4 \%$ CA type A & 14.00 & 2.16 & 40.73 & 0.91 \\
\hline \multicolumn{5}{c}{ Table 3-4. Average and std. deviation for compressive strength and slump test. }
\end{tabular}

On the contrary, an amount of $2 \%$ of CA type A did not improve the compressive strength of the concrete. CA type B needed an amount of $8 \%$ by cement weight to show an increase of the compressive strength (Fig. 3-29 left). However, the results when using the CA type C in a dosage of $8 \%$, as used in one experimental campaign, led only to slightly better compressive strength results, either when using fiber content of $70 \mathrm{~kg} / \mathrm{m}^{3}$ or $40 \mathrm{~kg} / \mathrm{m}^{3}$ (Fig. 3-29 right). 

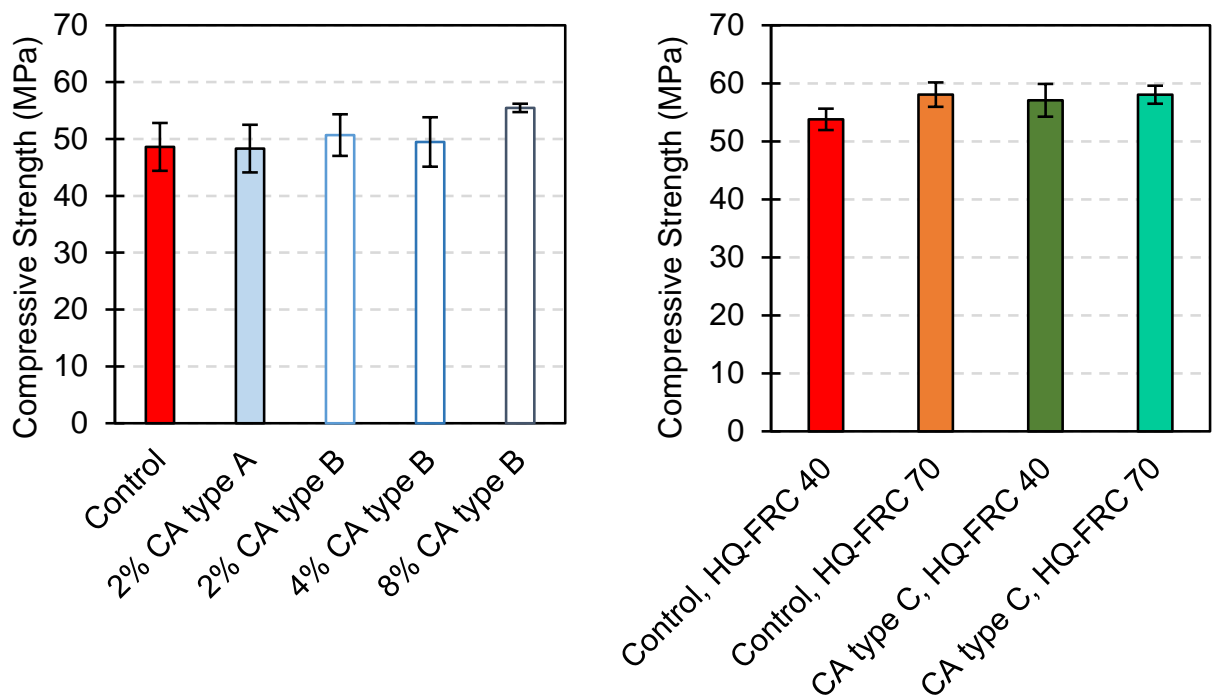

Fig. 3-29. Avg. compressive strength with $2 \%$ of CA type A, and increasing amounts of CA type B (left) and with different contents of fibers and $8 \%$ of CA type C (right).

\subsubsection{Workability and compressive strength of mortars}

Consistency of mortar was tested following EN 1015-3 incorporating CA type A and without using superplasticizers neither in the Control nor in the CA mixes. The setup needs a flow table, frustum mold (60 mm in height, internal diameter: base $100 \mathrm{~mm}$ - top $70 \mathrm{~mm}$ ) and a tamper, as displayed in Fig. 3-30. The mold is filled in 2 layers and tamped 25 times. The excess of mortar is removed from the top and then the table is activated to jolt 15 times (one per second). The resulting diameter of the spread mortar is measured in two orthogonal directions.

Fig. 3-30 shows that Control mix had lower flowability than the mix with CA type A. Minislump test was performed to evaluate this difference, and the results show that the obtained average diameter was around 50\% higher in the case of the CA mix (Table 3-5). The CA mix showed a starting of segregation at the end of the tampering steps. The consistency levels are defined following EN 1015-6.

\begin{tabular}{ccccc} 
& Diameter 1 $(\mathbf{m m})$ & Diameter 2 $(\mathbf{m m})$ & Avg. diameter $(\mathbf{m m})$ & Consistency \\
\hline Control & 100 & 105 & 102.5 & Dry \\
\hline CA type A & 160 & 155 & 157.5 & Plastic \\
\hline
\end{tabular}

Table 3-5. Values of diameter obtained with the mini slump test. 

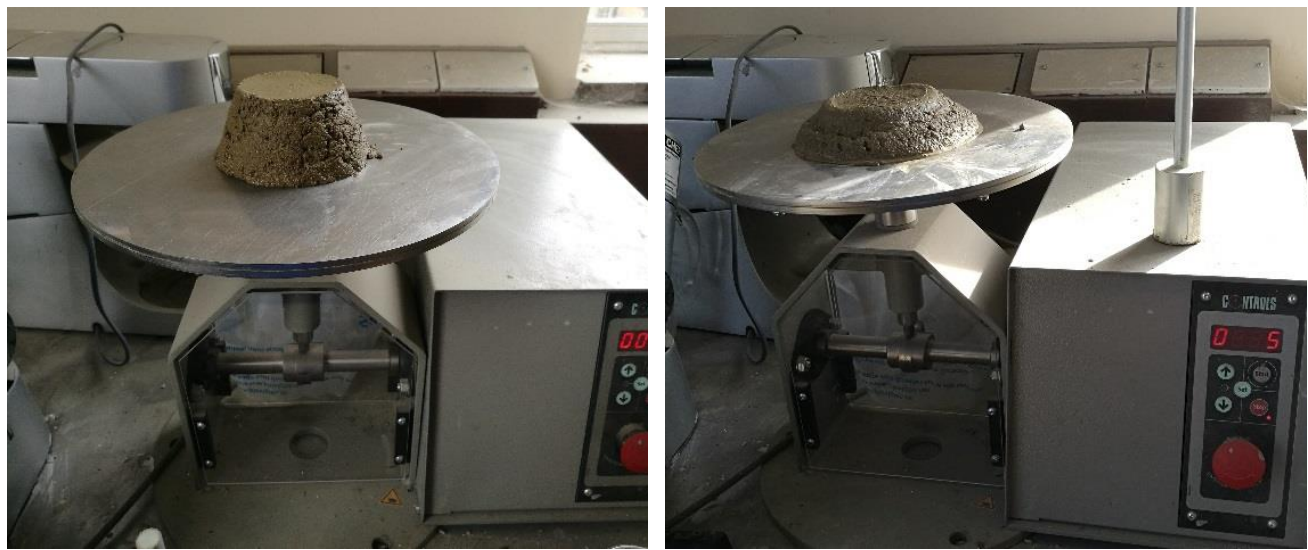

Fig. 3-30. Appearance of the two mixes after 15 compacting steps.

Compressive strength on $40 \mathrm{~mm} \times 40 \mathrm{~mm} \times 40 \mathrm{~mm}$ cubes was tested for all mixes at the ages of 2, 7 and 28 days (see Fig. 3-31 left) using a Controls compressive strength machine. After the results of CA admixtures showing not enough strength at 2 days (see Fig. 3-31 right), another sets were tested at the age of 3 and 4 days to trend of acquisition of strength and complement with the calorimetry results. Additional cubes from control mix were tested at those ages with comparing purposes. Parameters of the test were test speed of $2400 \mathrm{~N} / \mathrm{s}$ and Peak Sensitivity of $5 \mathrm{kN}$.
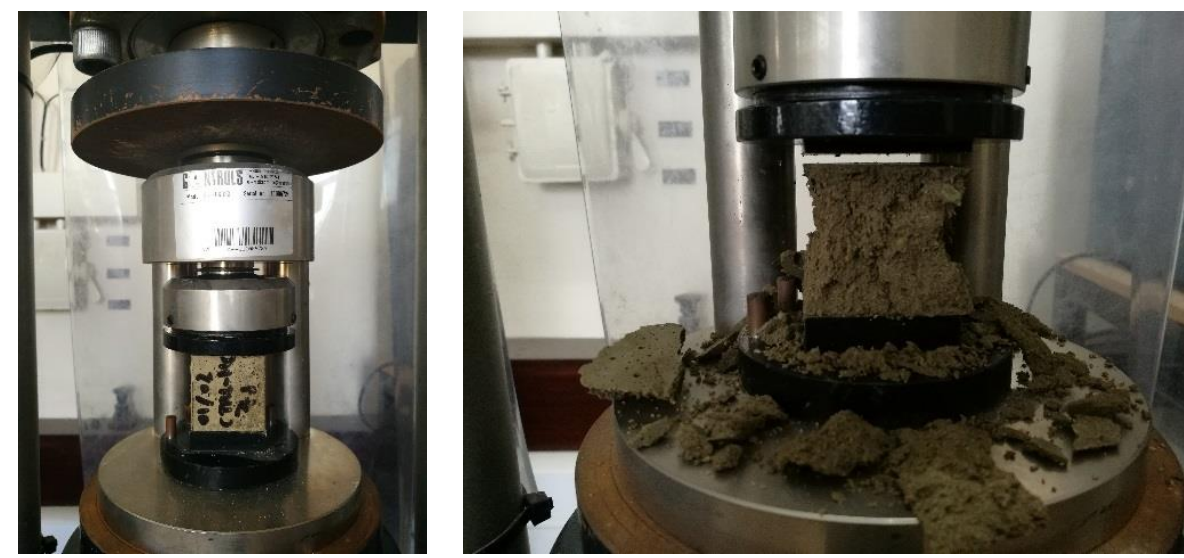

Fig. 3-31. Compressive strength of mortar cubes (left) and CA mortar cube broken at 2 days (right).

Results are displayed in Fig. 3-32, showing that CA dramatically decreased strength during the first 2 days, but after 3 days it is increased noticeably compared with control specimens. 
Chapter 3. Selection and development of the experimental methods

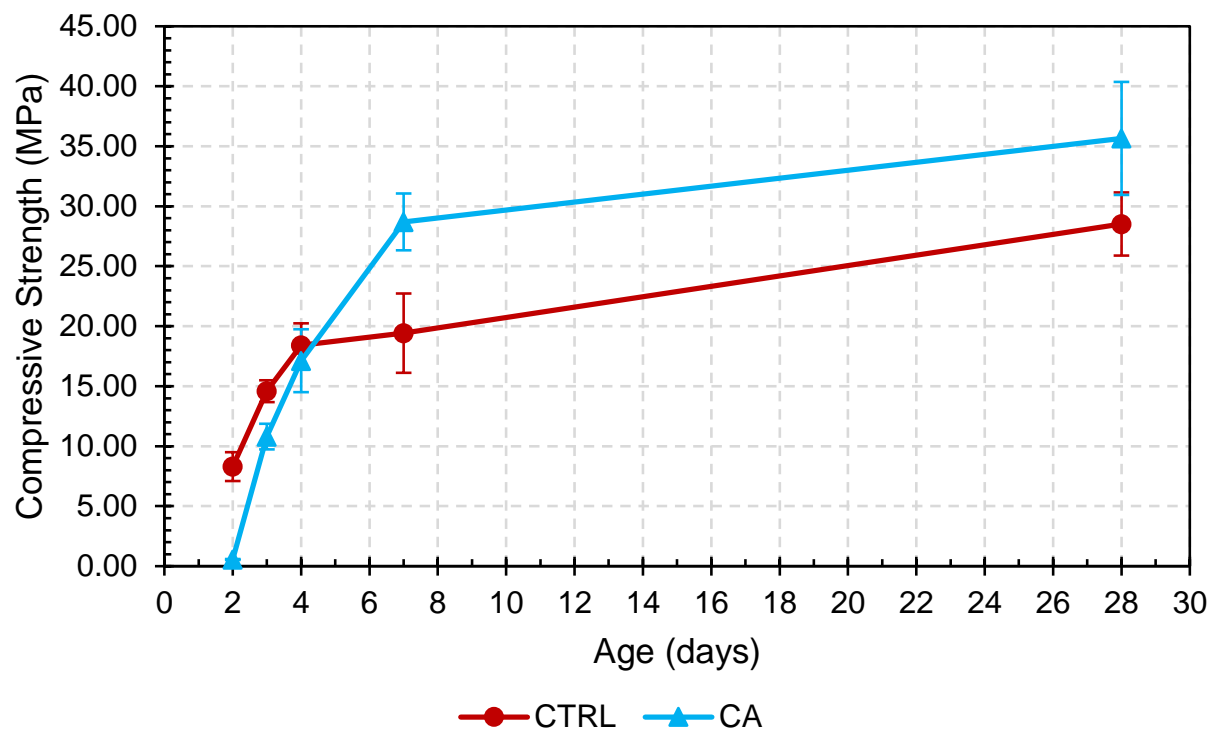

Fig. 3-32. Compressive strength evolution with age for Control and CA mixes.

Regarding the dispersion between groups inside each casting group, Fig. 3-33 shows for the control group that the mix CTRL-7d-WI had smaller compressive strength; this was produced by an insufficient compaction. CA mixes (Fig. 3-34) showed higher dispersion of compressive strength results when tested at the age of 28 days, but very similar for the rest of ages.

\section{Values of compressive strength per group}

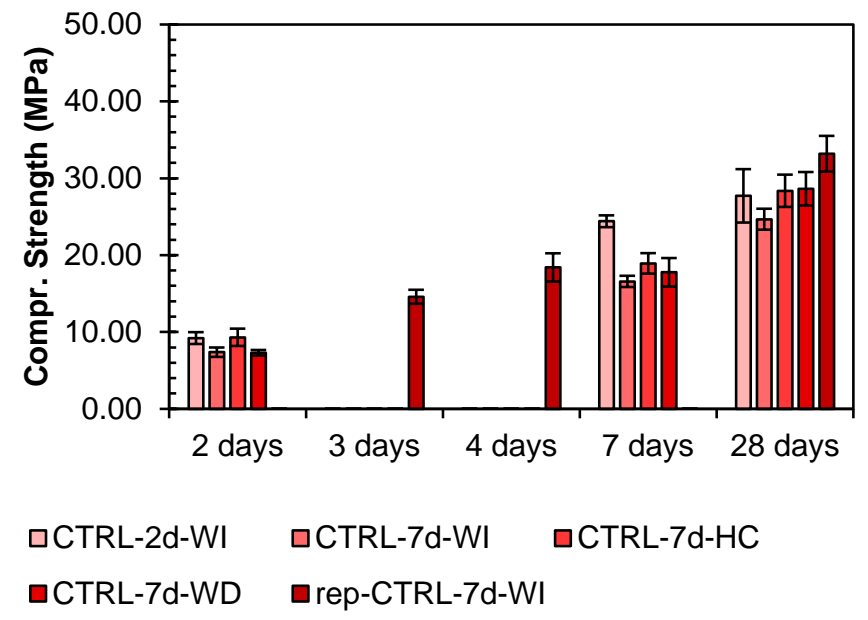

Fig. 3-33. Average compressive strength per mixing group for control mixes. 


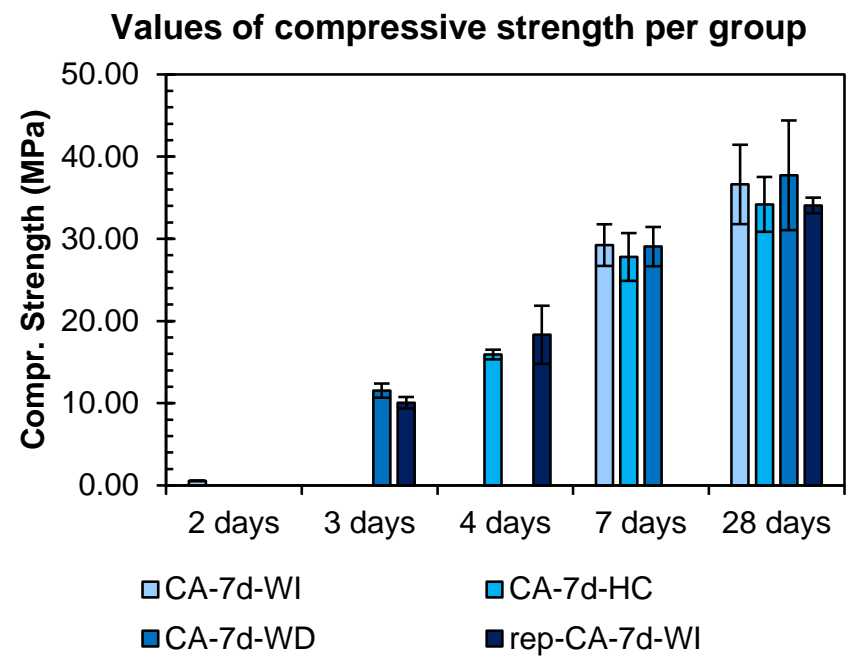

Fig. 3-34. Average compressive strength per mixing group for CA mixes.

\subsubsection{Effect of CA on the hydration of mortars}

To evaluate the effect of adding crystalline admixtures into concrete, a small campaign of isothermal calorimetry tests has been performed to measure the heat generated from the hydration process of cement and cement plus the admixture.

Calorimetry test was made to 35 grams mortar samples with $0,1,2$ and $4 \%$ of CA type A and the new admixture (type D) using an I-Cal 2000 HPC Isothermal Calorimeter, compliant with ASTM C1679. The amount of each compound is proportional to the mortar composition used in the sorptivity tests, and substituting sand content by increasing crystalline admixture, as displayed in Table 3-6.

\begin{tabular}{ccccc}
\hline (gr) & Control & 1\% CA & 2\% CA & 4\% CA \\
\hline Cement & 7.78 & 7.78 & 7.78 & 7.78 \\
Water & 3.89 & 3.89 & 3.89 & 3.89 \\
Sand & 23.33 & 23.25 & 23.17 & 23.02 \\
CA & - & 0.078 & 0.16 & 0.31 \\
\hline \multicolumn{5}{r}{ Table 3-6. Composition used for the mortars of the calorimetry. }
\end{tabular}

The materials used for the isothermal calorimetry test are displayed in Fig. 3-35 left. Previously to start recording the heat flow and energy, the equipment and materials are preconditioned putting water and sand inside the calorimeter for two hours. Afterwards, the compounds are mixed manually (Fig. 3-35 center and right) and the exact time of introducing the mix inside the equipment is indicated in the software. The test is kept running for 3 days (Fig. 3-36) to have a wide range covering the most important range for the hydration reactions of the cement. 

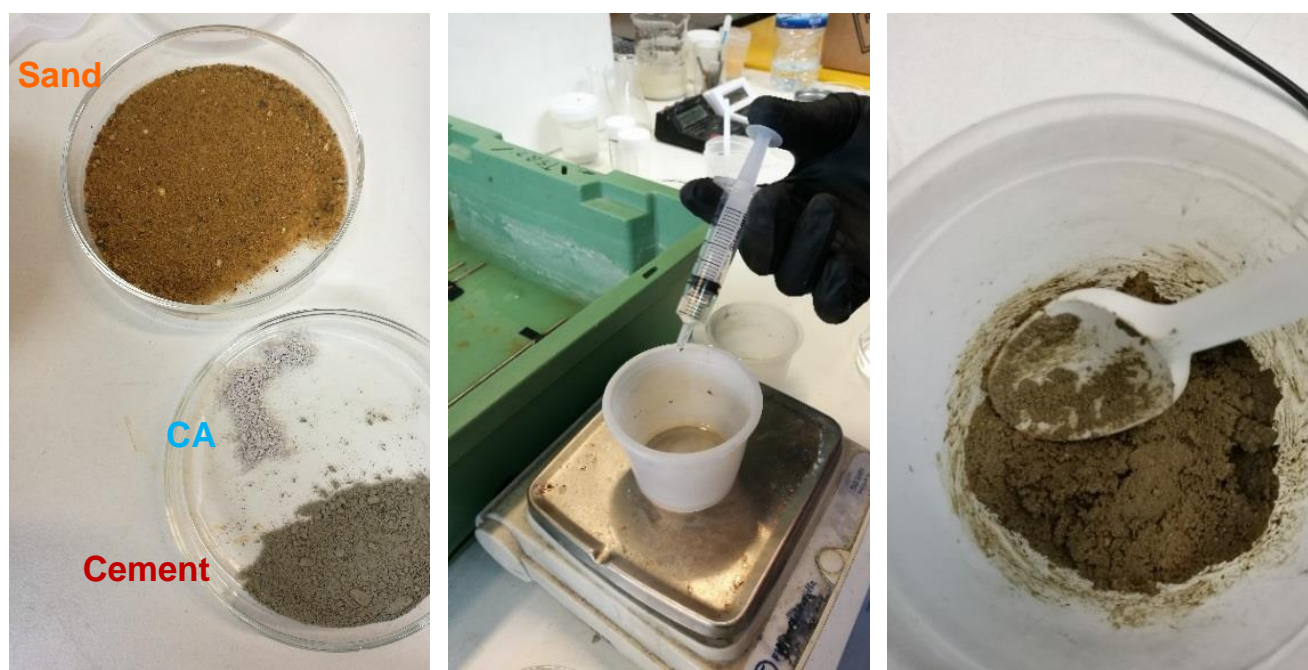

Fig. 3-35. Materials used for the calorimetry (left), use of a syringe for measuring the amount of water (center) and manual mixing of the compounds (right).
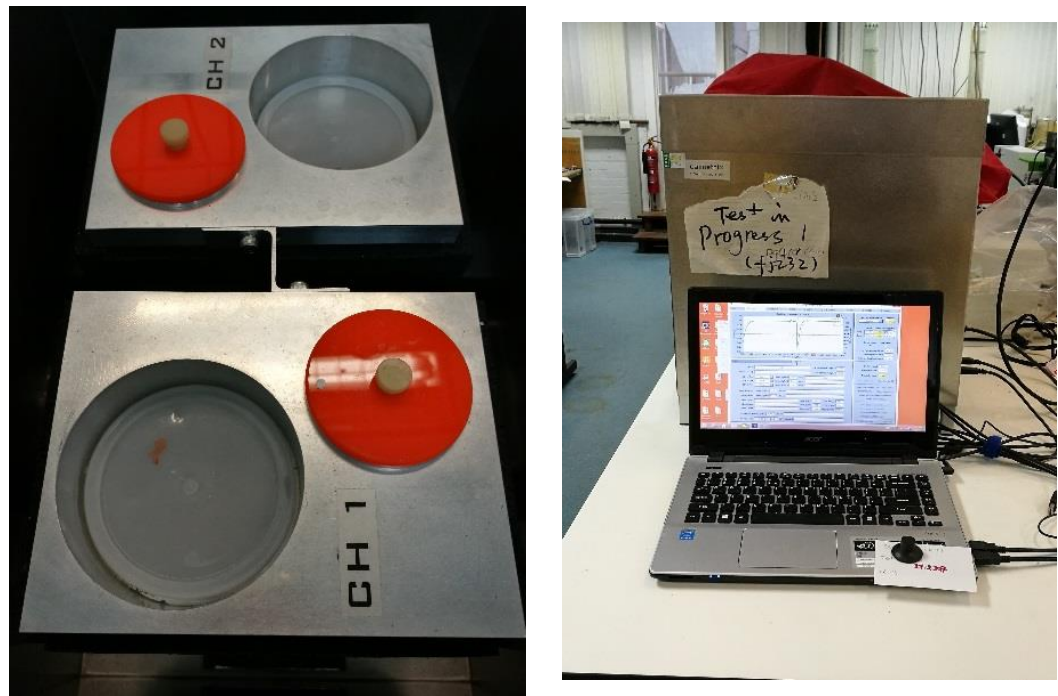

Fig. 3-36. Recipients inside the calorimeter (left) and computer and calorimeter set up (right).

From the isothermal calorimetry, the rate of hydration can be estimated with the heat of hydration (P), and the its extent with the energy or heat parameter (E).

The peak power can be calculated as the maximum power (first peak) minus the power during the induction period. The initial setting time can be estimated as the time at onethird of the peak power. Control sample presented a typical calorimetry curve (Fig. 3-37). 


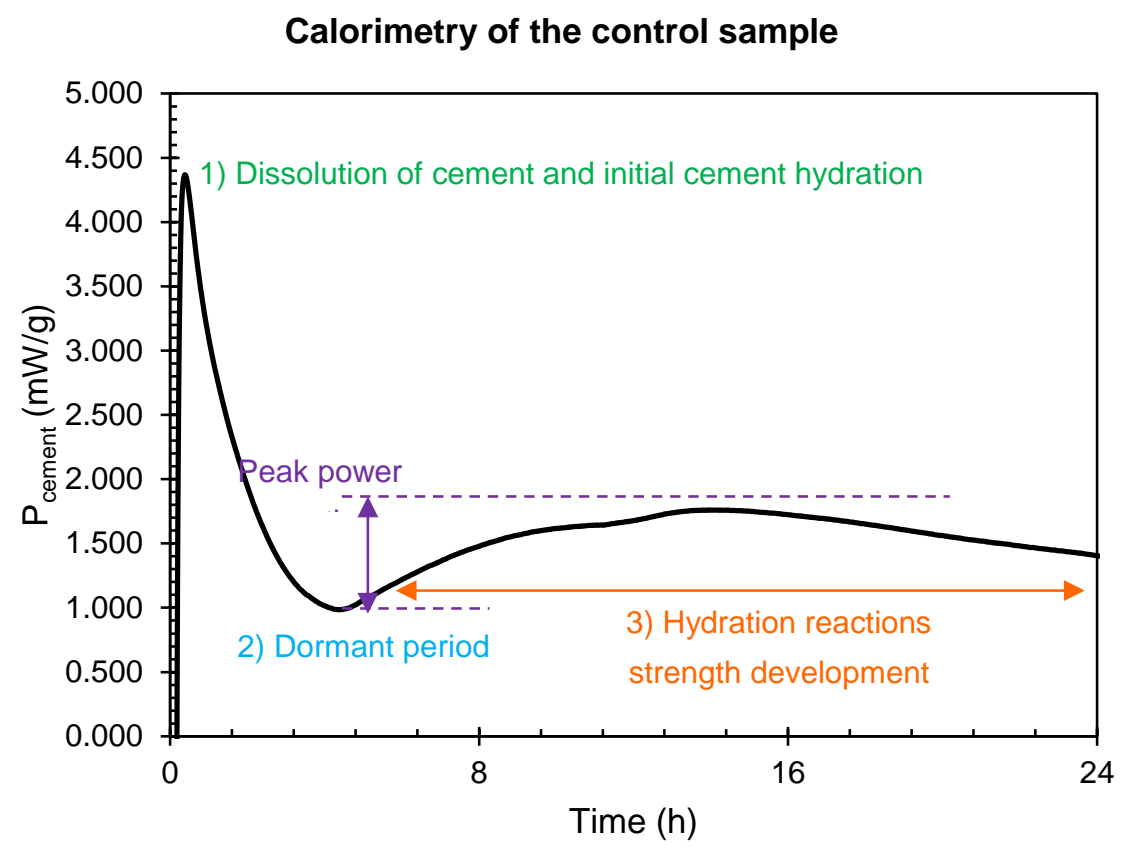

Fig. 3-37. Heat flow of control sample.

Fig. 3-38 and Fig. 3-39 show respectively the effects on heat flow and heat produced by adding the Crystalline Admixture type A. Analyzing the Heat Flow (P) curves, it can be deduced that when using this CA the dormant period has lower thermal power, indicating slower hydration. The peak of heat flow is delayed as the admixture content increases; thus, it can be confirmed that this CA delays hydration. The peak of the heat flow curves is delayed around 8 hours for $1 \%$ of CA, 12 hours for $2 \%$ of CA and 18 hours for $4 \%$ of CA. After 30 hours, the control sample has the lower activity, while samples with increasing content of the CA had higher thermal activity.

Regarding the energy or heat curves (E), the curve with $1 \%$ and $2 \%$ of $\mathrm{CA}$ are almost parallel to the reference curve, indicating that the behavior is not changed, but being lower when increasing the CA content. Because of that, the strength is presumably smaller when increasing the amount of CA for those ages. However, for $4 \%$ of CA the curve shows a different trend, it has smaller values than the reference curve, but with a much higher slope after 24 hours, which, if the trend was maintained after the 72 hours of the test, indicates that around 4 days it can reach the control curve. This would be coherent with the results obtained by compressive strength. 

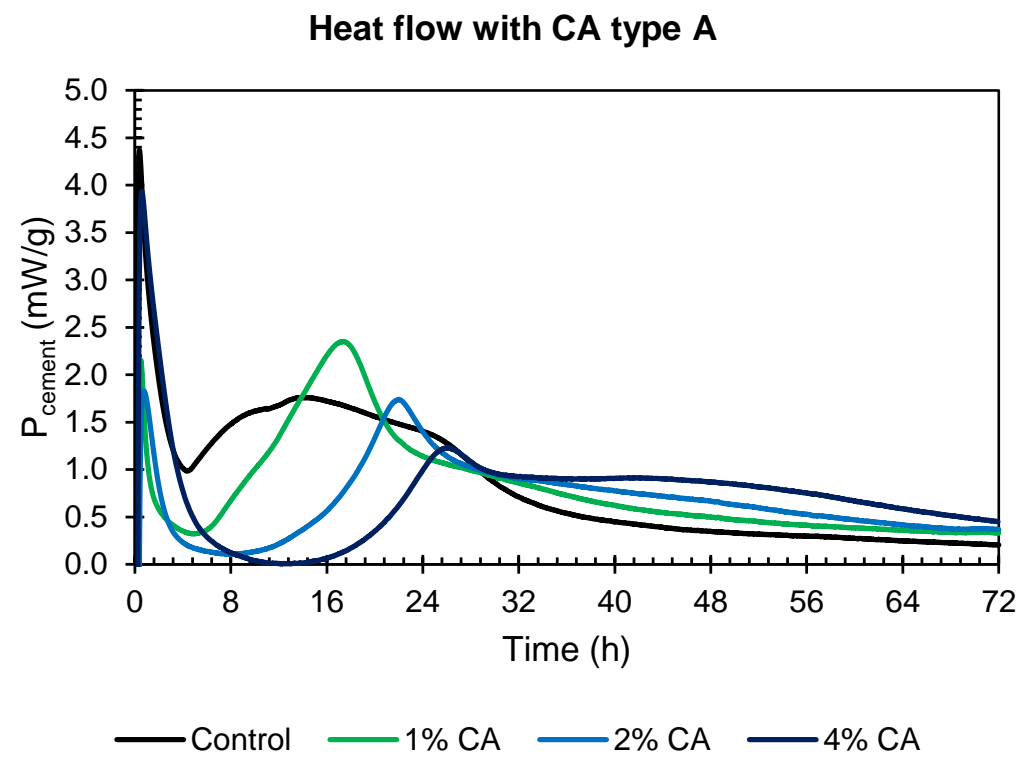

Fig. 3-38. Heat flow results for crystalline admixture type A for the first 72 hours compared with the control sample.

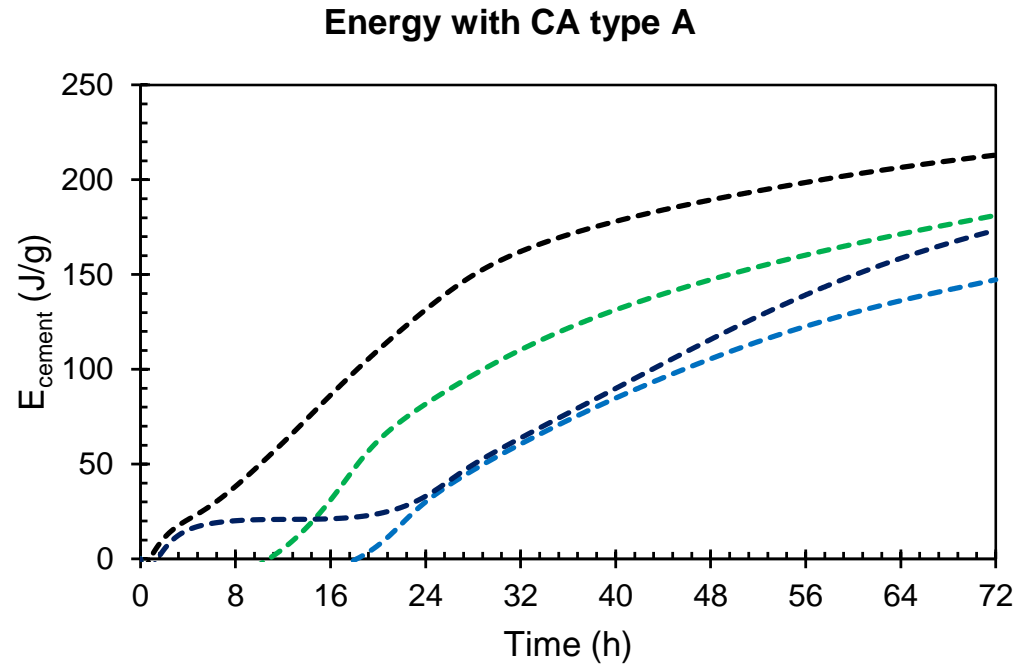

.-- Control - $--.1 \%$ CA $---.2 \%$ CA $---.4 \%$ CA

Fig. 3-39. Heat of hydration results for crystalline admixture type A for the first 72 hours compared with the control sample. 
A new CA (type D) was also received in the lab and tested with calorimetry. This new admixture had a different response, showing at least two separated peaks of activity, at 25, 50 and presumably also at 72 hours (Fig. 3-40). These results show that the use of this admixture produces two-three peaks of thermal activity, compared to the only peak of control mix. Groups with dosages of $1 \%$ and $2 \%$ of the new CA had similar responses, while increasing the content to $4 \%$ leads to a more horizontal curve.

In this case, the energy corresponding to the groups with 1 and $2 \%$ of $\mathrm{CA}$, compared with control, have similar values at 24 hours and higher at 72 hours, therefore, similar strength is expected at 24 hours and higher at 3 days (Fig. 3-41). This would be a different behavior compared with the previous admixture, whose calorimetry results suggest a delay of the acquisition of strength even when using contents of 1 and $2 \%$.

In the case of this admixture, an amount of $4 \%$ is probably not practical, since the peaks of activity and energy when using smaller amounts are greater. In contrast, the previously analyzed admixture seemed to overcome energy values (because of its higher slope) when compared to control and samples with smaller dosages. This did not occur when using this new admixture.

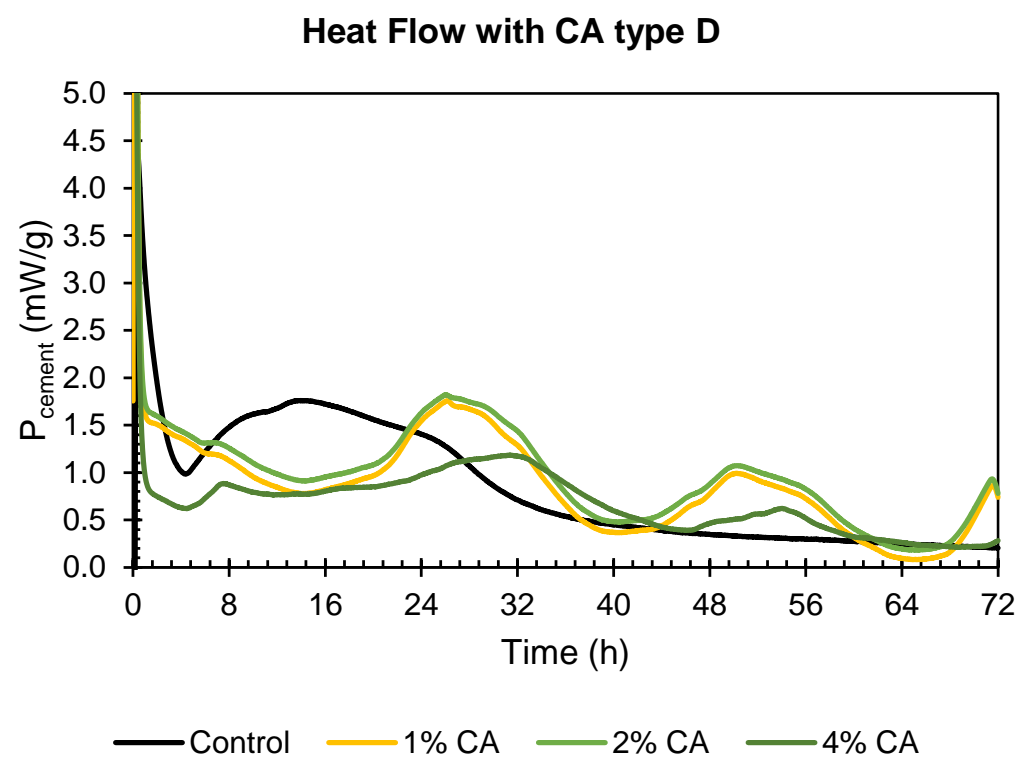

Fig. 3-40. Heat flow results for the crystalline admixture type D for the first 72 hours compared with the control sample. 


\section{Energy with CA type D}

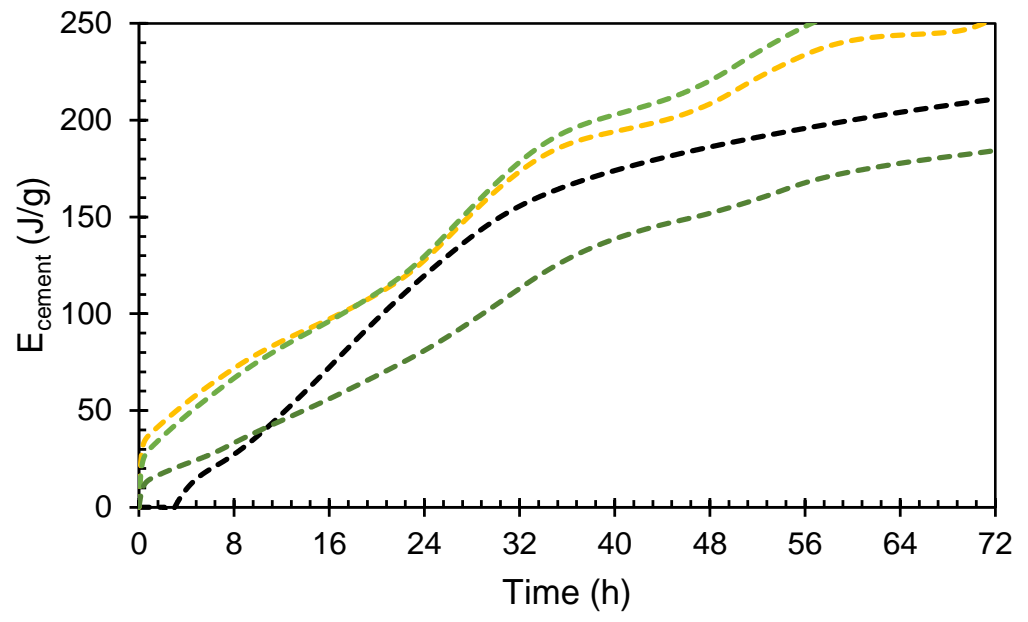

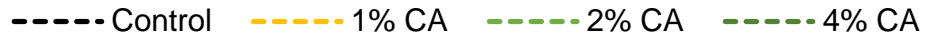

Fig. 3-41. Heat of hydration results for the crystalline admixture type $D$ for the first 72 hours compared with the control sample.

These results, combined with the oxide characterization results for the different CA, indicate that different products, potentially providing different properties, could be currently being used under the label of CA. 
Self-healing concrete: efficiency evaluation and enhancement with crystalline admixtures 


\section{Chapter 4. Validation of the methodologies for the evaluation of self- healing}


Self-healing concrete: efficiency evaluation and enhancement with crystalline admixtures 


\subsection{Introduction}

This chapter explains the different tests performed with the objective of testing specific details of the methodology used for the evaluation of self-healing properties. It also includes discussion of the obtained results with those presented in the literature review. The comparison of the healing efficiency obtained with autogenous healing and crystalline admixtures will be addressed in Chapter 5. The most extensive work has been carried out in the development and validation of water permeability and crack closing methods for the evaluation of self-healing in concrete. The focus on these two parameters is chosen due to their relevance in the watertightness and durability of structures.

This chapter is divided in the introduction and six sections.

Section 4.2 addresses specific topics related with the evaluation of crack closure, including the effect of the orientation of the crack while healing in different healing condition, and an estimation of parameters of precracking age and healing time needed to perceive the selfhealing effect.

Section 4.3 explain results regarding the water permeability test performed, showing the repeatability of the proposed test, and the effects of performing intermediate water permeability tests. This section also includes the estimation of parameters of precracking age and healing time needed to perceive the self-healing effect. Finally, it explains an experimental campaign to verify the presence or absence of internal precipitates and the permeability of the internal part of concrete specimens.

Regarding the mechanical properties, Section 4.4 addresses the choice of the reference and the expressions for the evaluation of mechanical regain and the effect of the amount of reinforcement. Section 4.5 addresses the use of sorptivity as the parameter to evaluate selfhealing using capillary absorption tests.

Then Section 4.6 addresses the comparison between different tests, focusing on the discussion for finding an appropriate crack geometrical parameter, between four different parameters, using as reference water permeability results.

Finally, Section 4.7 includes a discussion comparing with the results obtained in the literature review and a summary of the conclusions that can be drawn from this chapter, concerning the appropriateness and considerations for the evaluation of the self-healing capability of concrete elements.

\subsection{Crack closing}

This section explains different considerations for an adequate evaluation of crack closing. The parameters mentioned in Section 3.2 as crack geometrical parameters (maximum crack width, crack area, etc.) are compared later in Section 4.4 titled "Relation between crack closing and permeability tests" since the comparison is made in terms of a good adjustment to the water permeability response. In addition, this section will present studies to estimate the appropriateness of using early age cracks in terms of crack closing, and to estimate the healing time needed for having complete closing in the concrete specimens. 
Table 4-1 shows the list of subsections of this section addressing topics related with the evaluation of crack closing, indicating the objective of each subsection or experimental campaign, the size of the program in terms of number of specimens analyzed and related subsections, in which the same specimens were analyzed focusing on different properties.

\begin{tabular}{|c|c|c|c|}
\hline Subsection & Objective & $\begin{array}{l}\text { Size of the experimental } \\
\text { program }\end{array}$ & $\begin{array}{l}\text { Related } \\
\text { subsections }\end{array}$ \\
\hline $\begin{array}{l}4.2 .1 \\
\text { Orientation of } \\
\text { the crack } \\
\text { during healing }\end{array}$ & $\begin{array}{l}\text { Study of the influence } \\
\text { of the crack orientation } \\
\text { when healing in water, } \\
\text { wet/dry cycles and } \\
\text { humidity chamber in } \\
\text { mortars with and } \\
\text { without CA }\end{array}$ & $\begin{array}{l}3 \text { specimens analyzed per } \\
\text { group (total } 18 \text { specimens). } \\
3 \text { crack positions analyzed } \\
\text { per specimen }\end{array}$ & $\begin{array}{l}3.6 .2 \\
\text { Workability and } \\
\text { compressive } \\
\text { strength of } \\
\text { mortars }\end{array}$ \\
\hline $\begin{array}{l}4.2 .2 \\
\text { Precracking age } \\
\text { effect in } \\
\text { mortars }\end{array}$ & $\begin{array}{l}\text { Comparison of crack } \\
\text { closing rates in } \\
\text { mortars with and } \\
\text { without CA healing in } \\
\text { water, wet/dry cycles } \\
\text { and humidity chamber } \\
\text { and comparison } \\
\text { between precracking } \\
\text { at } 2 \text { and } 7 \text { days }\end{array}$ & $\begin{array}{l}3 \text { specimens analyzed per } \\
\text { group (total } 18 \text { specimens). } \\
3 \text { crack positions analyzed } \\
\text { per specimen. Photos } \\
\text { taken after } 0,7,14 \text { and } 28 \\
\text { days of healing. In total } \\
216 \text { photos analyzed }\end{array}$ & $\begin{array}{l}\text { mortars } \\
\begin{array}{l}4.6 \text { Sorptivity } \\
\text { evaluation }\end{array} \\
5.4 \text { Sorptivity }\end{array}$ \\
\hline $\begin{array}{l}4.2 .3 \text { Estimation } \\
\text { of the healing } \\
\text { speed and } \\
\text { healable crack } \\
\text { width in } \\
\text { concrete }\end{array}$ & $\begin{array}{l}\text { Comparison of crack } \\
\text { closing rates in } \\
\text { concrete healing in } \\
\text { water, wet/dry cycles } \\
\text { and humidity chamber } \\
\text { for two crack sizes }\end{array}$ & $\begin{array}{l}2 \text { crack sizes ( } 0.1 \text { and } 0.4 \\
\text { mm). } 3 \text { healing exposures. } \\
3 \text { specimens per group, } 2 \\
\text { cracks per specimen. Total } \\
\text { of } 36 \text { cracks analyzed. } \\
\text { Photos taken after } 0,7,14 \text {, } \\
28 \text { and } 42 \text { days of healing. } \\
\text { In total } 180 \text { photos } \\
\text { analyzed }\end{array}$ & $\begin{array}{l}5.5 .2 \\
\text { Verification of } \\
\text { the internal } \\
\text { carbonation }\end{array}$ \\
\hline
\end{tabular}

\subsubsection{Orientation of the crack during healing}

This campaign focused on the evaluation of crack closing. The effect of the orientation of the crack while healing in three different exposure conditions is analyzed as a variable. Specimens were placed horizontally with the crack in condition of repose (see Fig. 4-1). The analysis of the healing speed results will be analyzed in Chapter 5.

The mixture proportions used for this work follows the reference mix from EN 196. For the mix with crystalline admixtures, they were added by substitution of the sand (Table 4-2). The crystalline admixture used is Type $\mathrm{A}$ in a dosage of $4 \%$ by the weight of cement. The list and composition of the different crystalline admixtures used in this work were explained in Subsection 3.1.4 "List of CA and oxide composition".

All specimens had a steel wire as a reinforcement to maintain the stability of the crack. Specimens were precracked at the age of 7 days to achieve cracks of around $0.30 \mathrm{~mm}$ by means of three point bending test. Three specimens were analyzed per each group. 
Chapter 4. Validation of the methodologies for the evaluation of self-healing

\begin{tabular}{ccc}
\hline (gr/liter) & Control & 4\% CA type A \\
\hline Cement & 450 & 450 \\
Water & 225 & 225 \\
Sand & 1350 & 1332 \\
CA & - & 18
\end{tabular}

Table 4-2. Mixture proportions for control and CA mortars.

Specimens were left to heal at the age of 7 days during 28 days in the following three healing conditions:

- HC (Humidity chamber): storage of the specimens inside a standard humidity chamber at $20^{\circ} \mathrm{C}$ and $95 \pm 5 \%$ relative humidity

- WD (wet/dry cycles): immersion in tap water at a temperature of $15^{\circ} \mathrm{C}$ for 7 days and humidity chamber for another 7 days; this process is repeated four times.

- WI_15 (water immersion at $15^{\circ} \mathrm{C}$ ): continuous immersion in tap water at a temperature of $15^{\circ} \mathrm{C}$, only adding water to maintain a constant water level;

Images of the cracks were taken before and after healing with a microscope Leica S6D with a camera DFC 295. Photos were taken after 0, 7, 14 and 28 days of healing. The imaging points were defined following the diagram in Fig. 4-1. Top crack was placed upwards in the healing exposure and points in the lateral crack are those inside the notch.

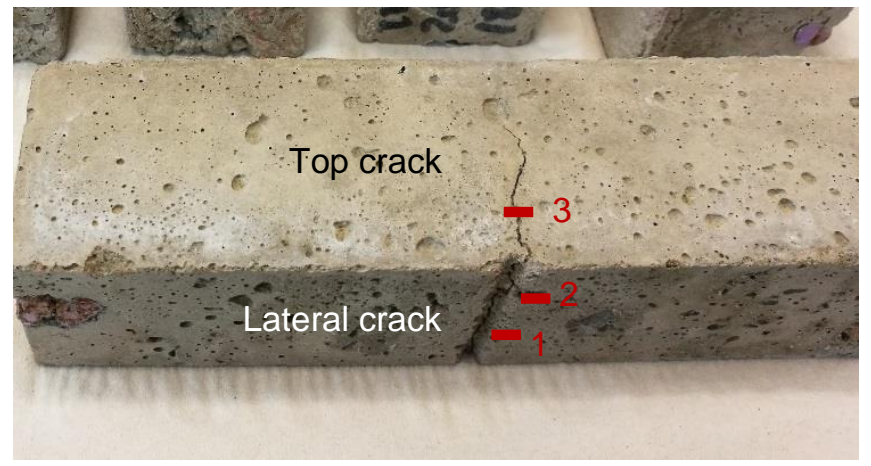

Fig. 4-1. Points defined to take the images and position of the specimen with the crack in repose.

An example for each healing condition (humidity chamber, water immersion, wet/dry cycles) and each mix (control and CA) is displayed in Fig. 4-2 for the case of lateral cracks and in Fig. 4-3 for top cracks. 
Self-healing concrete: efficiency evaluation and enhancement with crystalline admixtures

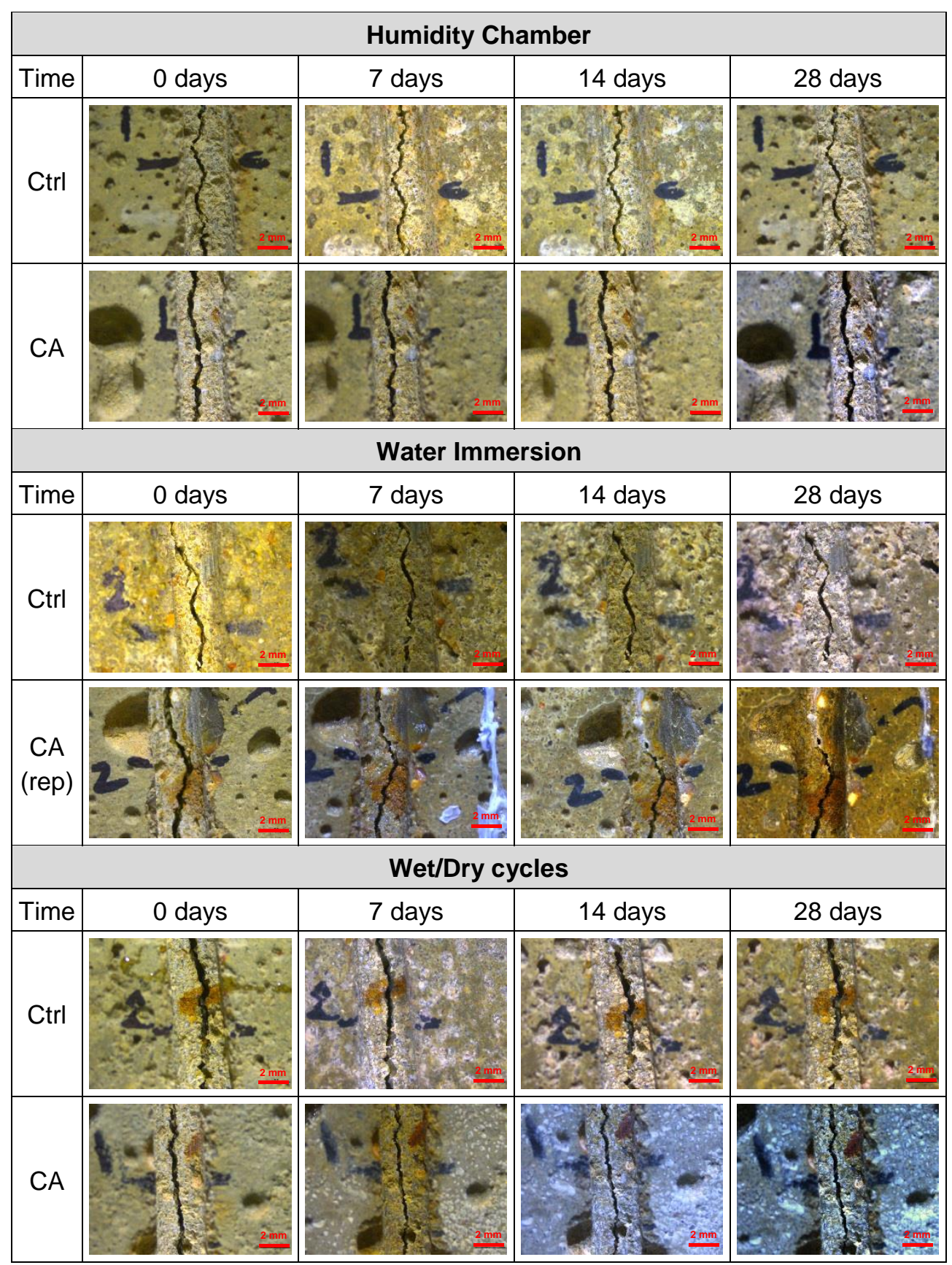

Fig. 4-2. Photos of crack closing at different ages for the three exposures for lateral cracks. 
Chapter 4. Validation of the methodologies for the evaluation of self-healing

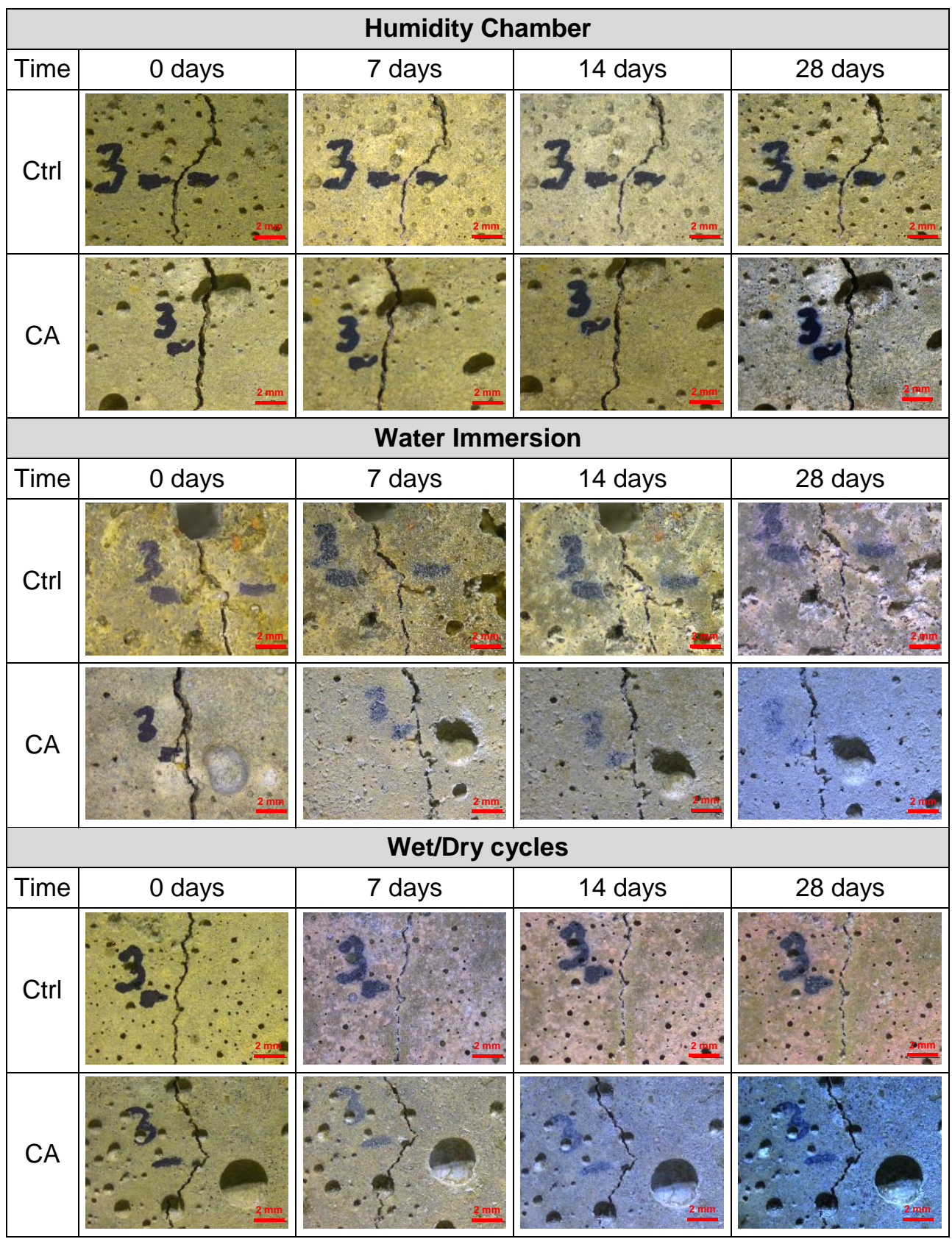

Fig. 4-3. Photos of crack closing at different ages for the three exposures for top cracks. 
The crack closing efficiency results are quite low for this experimental campaign. In general, cracks from all groups remained opened, but there are significant differences depending on the position of the crack: while lateral cracks remained open, top cracks accumulated precipitates in the whole surface (including the crack), and bottom cracks, which initially were outside the scope of this work, were those with the highest crack closing activity. The differences were of high importance, since top cracks in humidity chamber also got slight amount of precipitates, achieving widths of around $0.050 \mathrm{~mm}$ after 7 days of healing (Fig. 4-4).

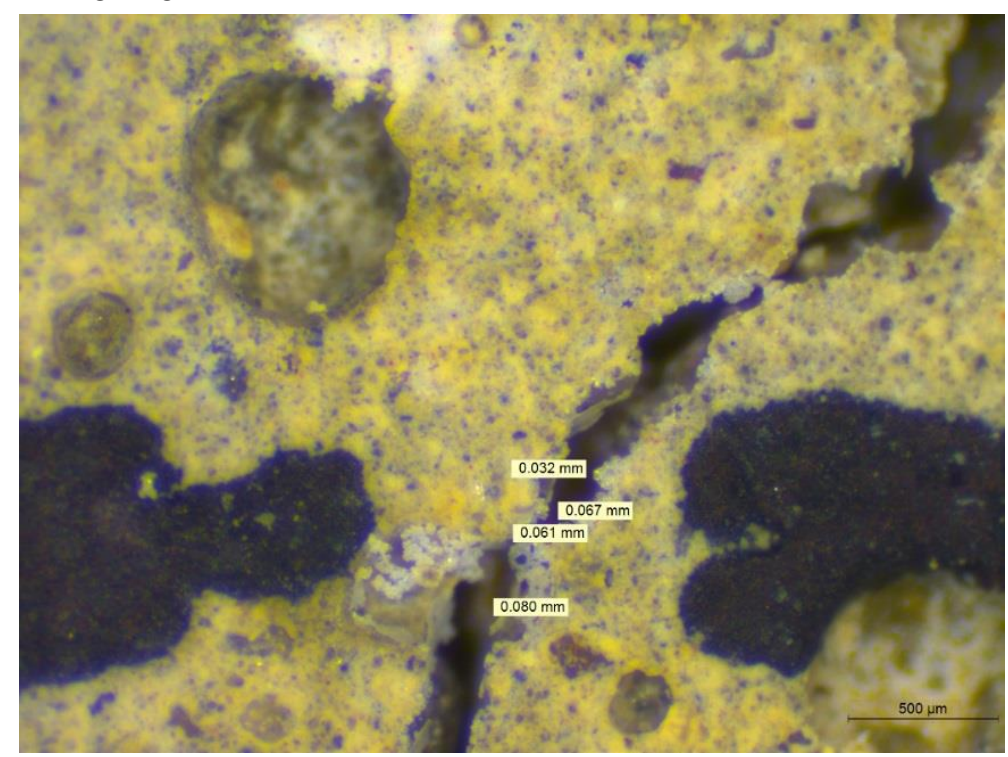

Fig. 4-4. Top crack of a control specimen healed in HC for 7 days.

However, significant precipitates in the form of stalactites were formed in the bottom crack in those specimens that were stored with enough space under them. These precipitates reached lengths of up to $5 \mathrm{~mm}$ without breaking and widths of around $0.2-0.3 \mathrm{~mm}$ (see Fig. 4-5). These precipitates also occurred for control specimens, but always for the bottom crack, where cracks up to $0.20 \mathrm{~mm}$ could be closed Fig. 4-6. 

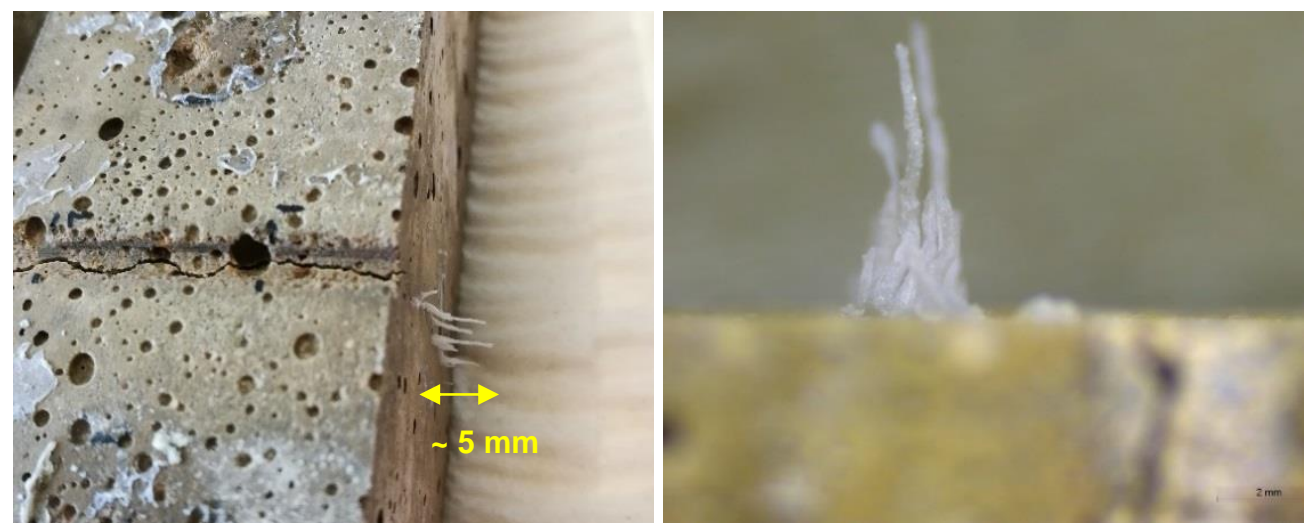

Fig. 4-5. Precipitates in the bottom crack of a CA specimen after 7 days of healing in WI.

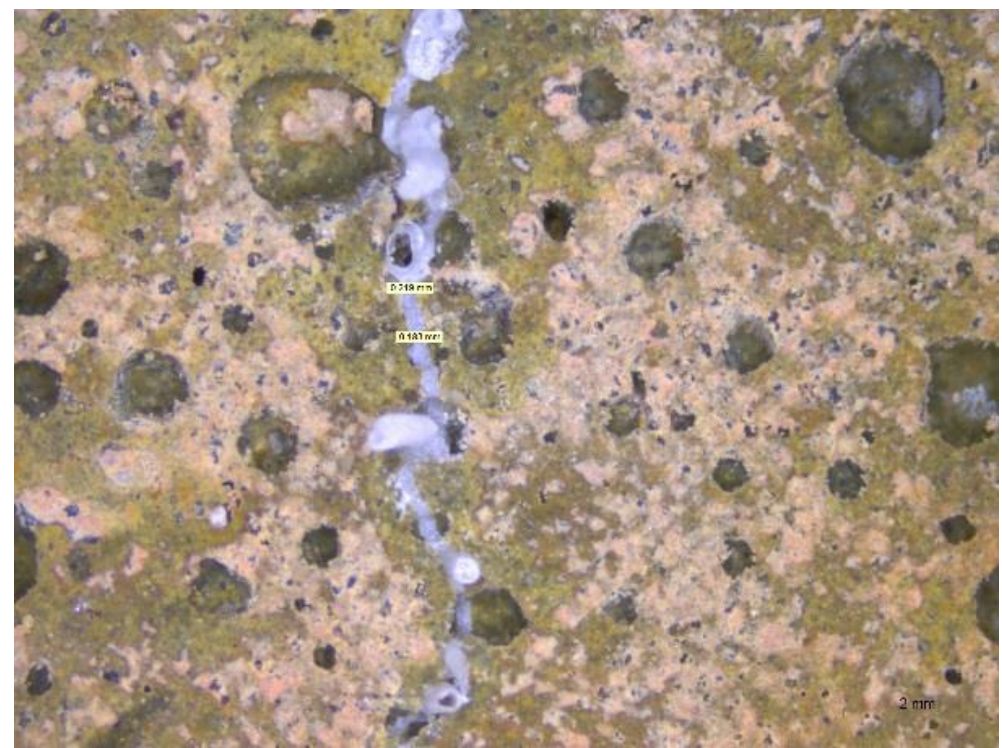

Fig. 4-6. Bottom crack of a CA specimen after 7 days of healing in WI.

This experimental work demonstrates the need to specify the orientation of the crack while healing, since the results can differ greatly otherwise. Another direct conclusion is that for having comparable results, all specimens should be placed in the same orientation while healing, to avoid an uncontrolled parameter. These results were taken into account in other campaigns, were the orientation of the specimens were kept constant to avoid adding variables to the study.

The composition of the precipitates formed in the healing process will be analyzed in Section 5.5 "Further insights about the healing reactions". 


\subsubsection{Precracking age effect in mortars}

This study compares the healing efficiency for two early ages of precracking, comparing specimens precracked at 2 and 7 days to verify its influence on autogenous healing. Specimens were left to heal at the age of 2 and 7 days, respectively, during 28 days. The mixture proportionsand the methodology followed are the same as used in Subsection 4.2.1.

Fig. 4-7 shows examples of the evolution of crack closing for a lateral and a top crack produced at the age of 2 days, and Fig. 4-8 for the equivalent precracked at the age of 7 days. The results show a clear better closing of the crack for cracks produced at 2 days instead of 7 days, highlighting the influence of continuing hydration on autogenous healing for this range of ages. Most of the reaction occurred in the first 7 days for top cracks and in the first 14 days for the lateral cracks. This shorter time for top cracks seems reasonable because of the surface deposition of precipitates.

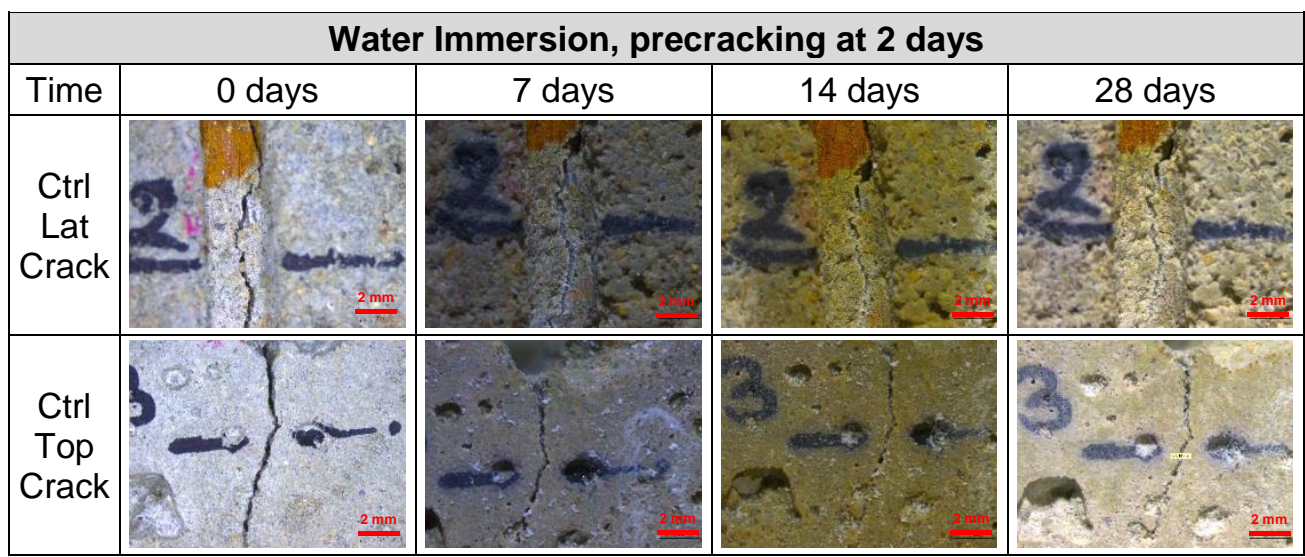

Fig. 4-7. Photos of cracks at different times of healing, for cracks produced at the age of 3 days.

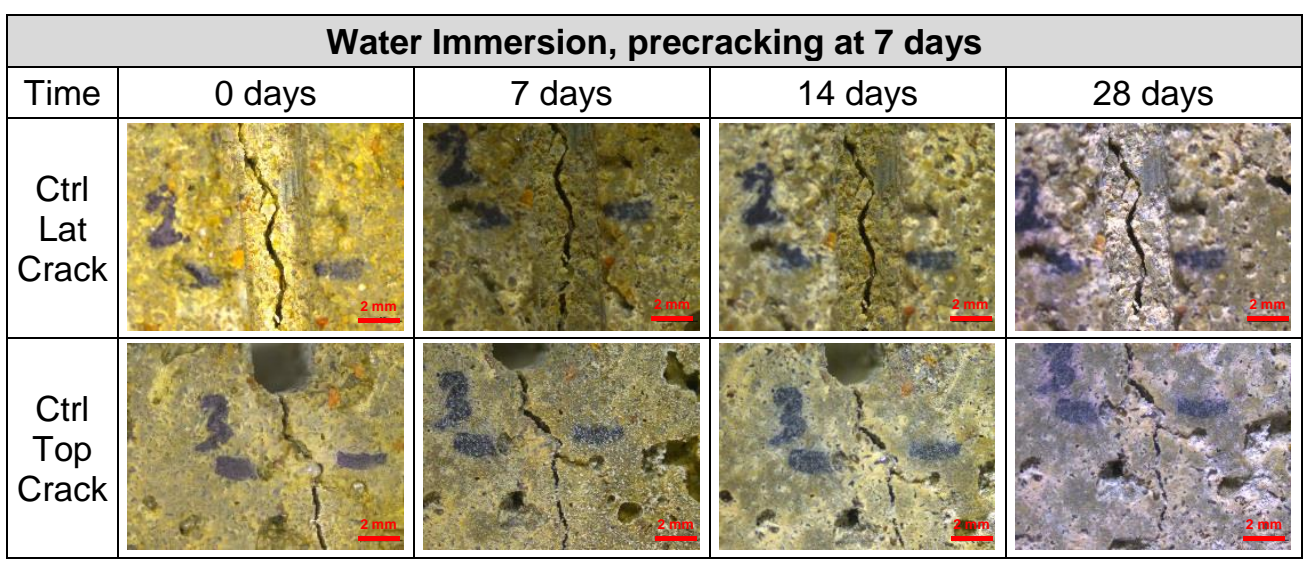

Fig. 4-8. Photos of cracks at different times of healing, for cracks produced at the age of 7 days. 


\subsubsection{Estimation of the healing speed and healable crack width in concrete}

This campaign has focused on the quantification of crack closing in concrete for different crack sizes ranging from 0.1 to $0.4 \mathrm{~mm}$, since other experimental campaigns performed used crack closing only as a secondary method. Performing other tests to the same specimen, such as the water permeability test, could affect the precipitates formation in the crack.

This study analyzes self-healing in concrete, whose composition is displayed in Table 4-3. Cylindrical concrete specimens $(\Phi 150 \times 150 \mathrm{~mm})$ were precracked at the age of 2 days, creating a crack using splitting test, targeting to crack widths of two levels: 0.1 and $0.4 \mathrm{~mm}$.

\begin{tabular}{cc}
\hline Material $\left(\mathbf{k g} / \mathbf{m}^{3}\right)$ & Control \\
\hline Cement CEM I 42.5 R & 275 \\
Water & 165 \\
Gravel (4-12 mm) & 908 \\
Natural sand & 988 \\
Steel fibers & 40 \\
Limestone powder & 50 \\
Crystalline Admixture & - \\
Table 4-3. Mixture proportionsused for the tests.
\end{tabular}

Three environmental exposure conditions were considered, maintaining the crack in lateral position in all the cases:

- HC (Humidity chamber): storage of the specimens inside a standard humidity chamber at $20^{\circ} \mathrm{C}$ and $95 \pm 5 \%$ relative humidity.

- WD (wet/dry cycles): immersion in tap water at a temperature of $15^{\circ} \mathrm{C}$ for 3.5 days and air exposure for another 3.5 days (air conditions: $17 \pm 1^{\circ} \mathrm{C}$ and $40 \pm 5 \% \mathrm{RH}$ ).

- WI_15 (water immersion at $15^{\circ} \mathrm{C}$ ): continuous immersion in tap water at a temperature of $15^{\circ} \mathrm{C}$.

All specimens were left to heal at the age of 3 days, during 42 days, and its cracks were measured and photographed after $0,7,14,28$ and 42 days of healing. Crack closing was evaluated in the central part of the crack length by using an optical USB microscope and photography software. A grand total of 12 cracks were analyzed per healing exposure (two for each of the six specimens).

Fig. 4-9 shows the evolution of the appearance of cracks of 0.1 and $0.4 \mathrm{~mm}$ healing in different conditions. Specimens stored at Humidity Chamber are clearly not experiencing healing, while specimens at Wet/Dry Cycles and Water Immersion achieved complete closing of small-sized cracks. Some cracks of size around $0.4 \mathrm{~mm}$ achieve high closing of the cracks, with better results for those specimens healed in water immersion. This result contrasts with some conclusions seen in the literature, in which the healing exposures with cycling regimes of immersion and drying conditions achieved better results compared with continuous water immersion (Yingzi et al., 2011; Sisomphon et al., 2013). 
Self-healing concrete: efficiency evaluation and enhancement with crystalline admixtures

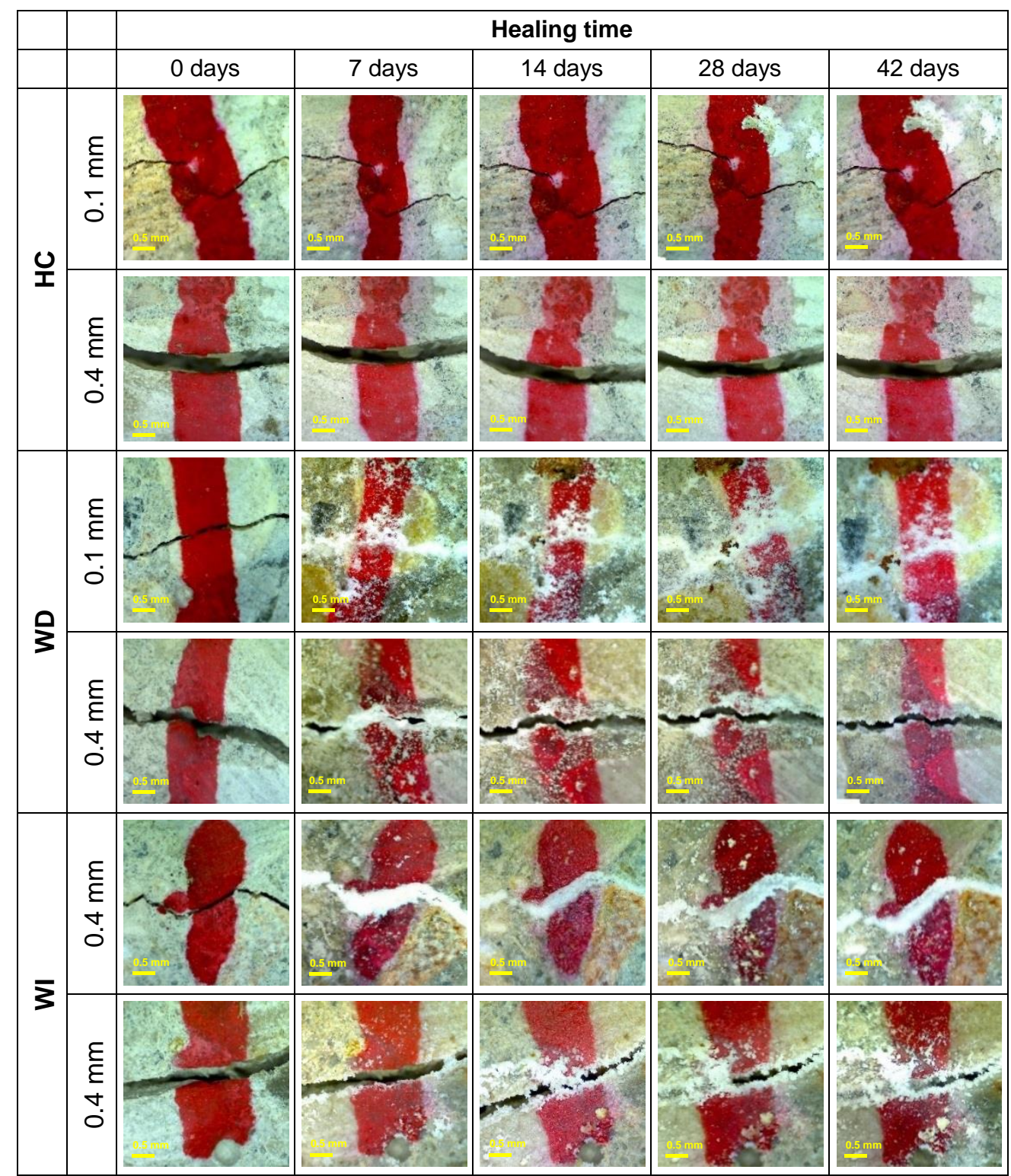

Fig. 4-9. Photos of cracks at different times of healing, for different sizes and exposures.

Some large cracks from specimens that healed under water immersion had tooth-like precipitates, with different visual appearance comparing with the surface precipitates. Fig. 4-10 and Fig. 4-11 show photos with the details of two cracks of $0.4 \mathrm{~mm}$. The former showing a specimen stored at humidity chamber showing no formation of precipitates, and 
the latter showing the precipitates formed in the surface and interior (close to the surface) of a specimen healed under water immersion.

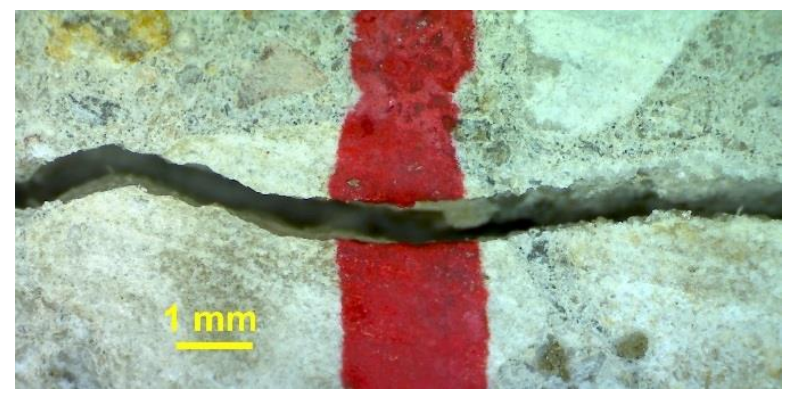

Fig. 4-10. Picture of a crack in a specimen healed in humidity chamber, without precipitates.

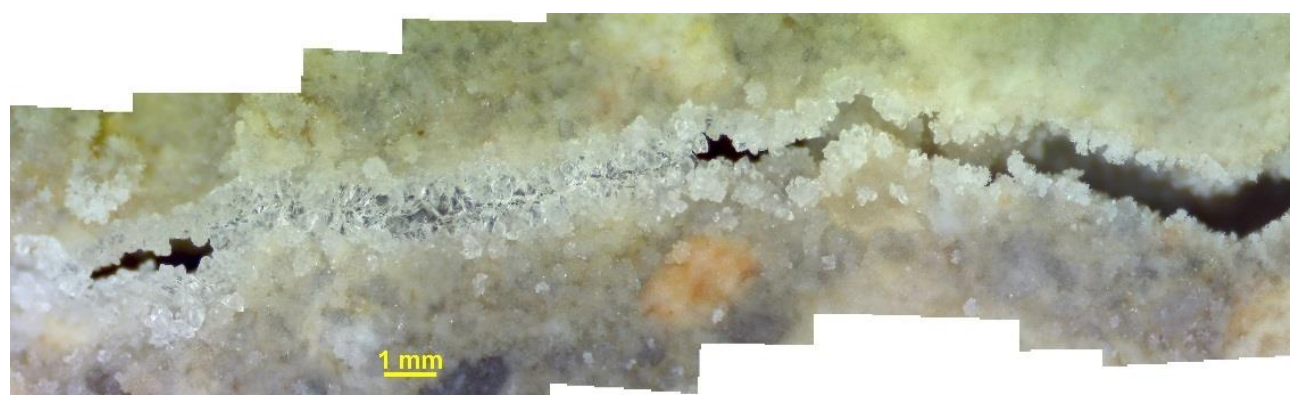

Fig. 4-11. Presence of tooth-like precipitates in specimens healed under water immersion.

The crack width of all these specimens was quantified and analyzed. Fig. 4-12 (left column) shows the evolution of crack closing for the 12 cracks that were analyzed for each of the three different exposures: top row for the humidity chamber, middle row for wet/dry cycles and bottom row for water immersion. The results show that humidity chamber has stable behavior, showing that the storage does not produce precipitates in the crack, and the variations of crack width are produced by the error in the measures. Those specimens healed in wet/dry cycles had quick formation of precipitates in the crack up to 14 days, but are stabilized afterwards. However, those specimens healing under water immersion had a decrease of crack width by the formation of the precipitates even after that time. Cracks of width over $0.42-0.45 \mathrm{~mm}$ are too large to start the formation of precipitates and closing the crack even under water immersion.

The right column of Fig. 4-12 shows the same results as calculated using the Crack Closing Ratio defined in Section 3.2. In this case, the results show some dispersion for the case of the specimens healed in Humidity Chamber for one specimen, but with the rest of the values oscillating around 0.00 . This dispersion is produced in the crack of smallest size because the expression is dividing two small numbers and the differences in the measure are outside the precision of the method. For specimens healing in the Wet/Dry Cycles and in Water Immersion the results obtained with this parameter give the same information as the crack closing evolution. 
Humidity Chamber

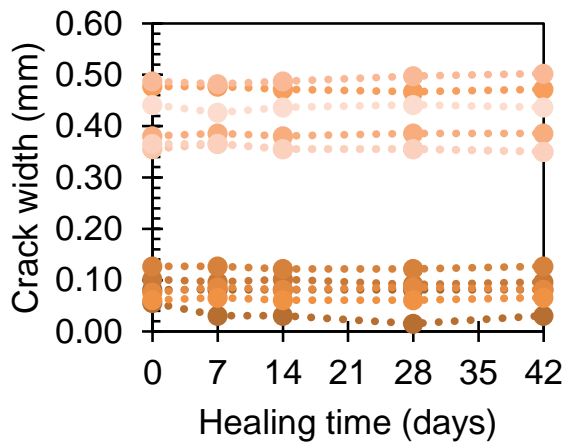

Wet/Dry Cycles

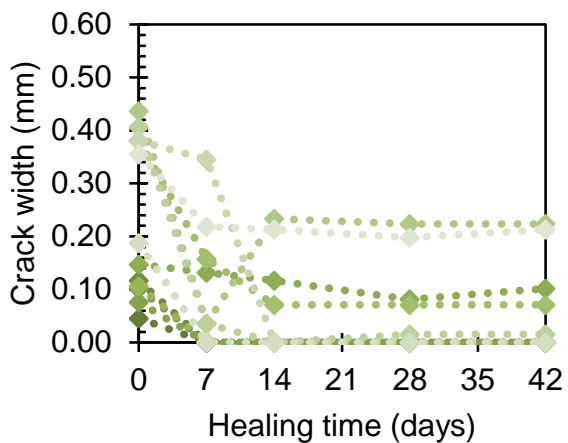

Water Immersion

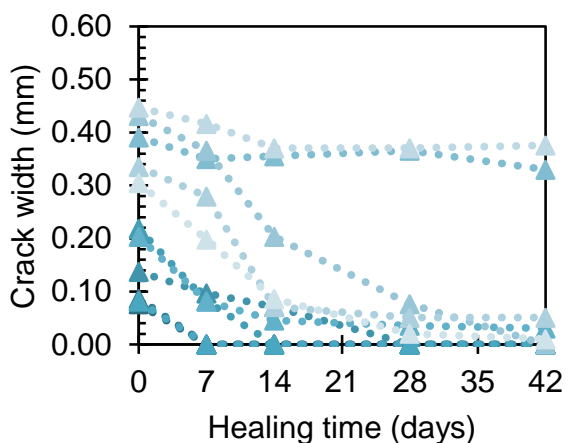

Humidity Chamber

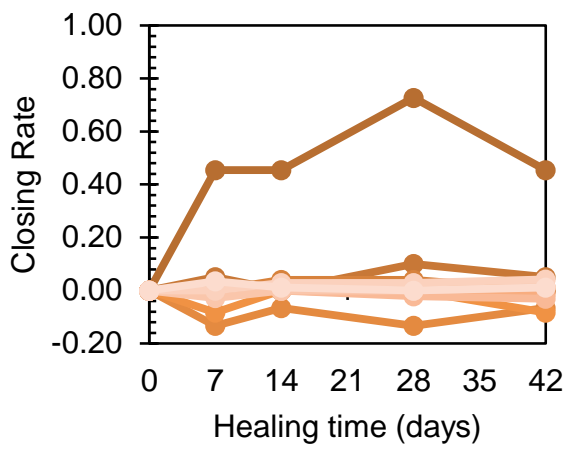

Wet/Dry Cycles

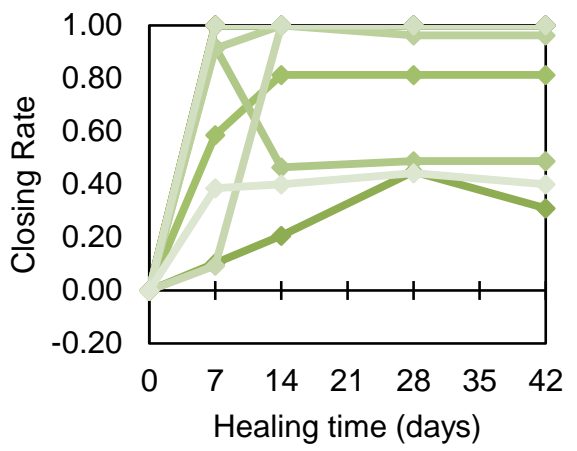

Water Immersion

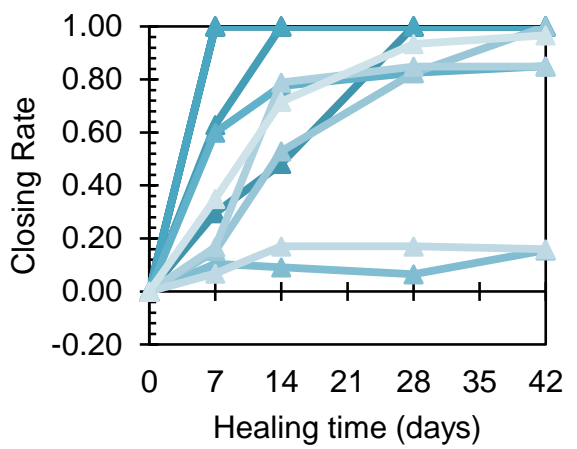

Fig. 4-12. Crack width (left) and closing rate (right) evolution with time for specimens under the three healing exposures. 
Analyzing the final values of crack closing ratio represented depending on their initial crack width (Fig. 4-13), it can be confirmed that specimens in humidity chamber did not heal independently of their initial crack width, and then can be used as a reference healing exposure. Those specimens healing under wet/dry cycles and water immersion achieved complete crack closing ratios for cracks under $0.15 \mathrm{~mm}$, and generally good closing ratios for cracks between 0.15 and 0.35 but it is drastically decreased for larger cracks.

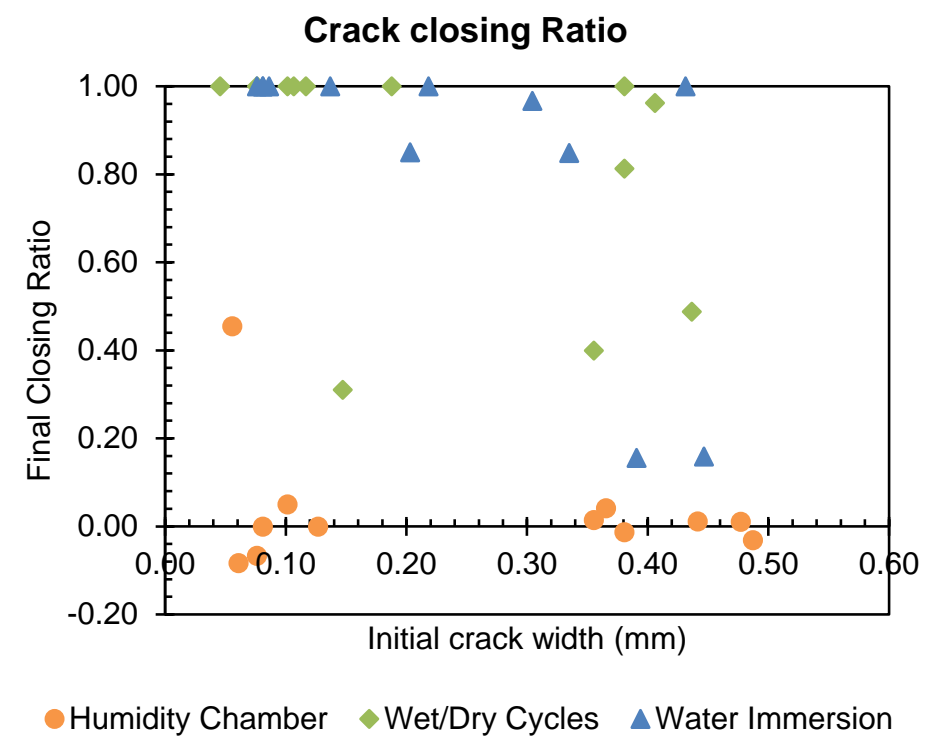

Fig. 4-13. Final values of crack closing tests after 42 days healing in the different exposures.

\subsection{Water permeability}

This section exposes the results obtained in different experimental campaigns performed in reference concrete without crystalline admixtures. The objective of the first campaign is to show the repeatability of the proposed water permeability test, by performing several repetitions at different times of healing in specimens without crack healing. The second focused on analyzing the influence of performing several water permeability tests at different healing times in specimens that experienced different damage extents (i.e. initial water flow). The third campaign will analyze the differences obtained by using two different precracking ages, one of early age and one later crack, on healing in terms of water permeability, and to estimate the needed time for having complete healing. Additionally, a fourth experimental campaign presents results on the healing produced in the internal part of the specimens, in terms of water permeability.

Table 4-4 details the list of subsections of this section addressing topics related with the evaluation of water permeability, indicating the objective of each subsection or experimental campaign, the size of the program and number of specimens analyzed and 
related subsections, in which the same specimens were analyzed focusing on different properties.

\begin{tabular}{|c|c|c|c|}
\hline Subsection & Objective & $\begin{array}{l}\text { Size of the } \\
\text { experimental } \\
\text { program }\end{array}$ & $\begin{array}{l}\text { Related } \\
\text { subsections }\end{array}$ \\
\hline $\begin{array}{l}4.3 .1 \\
\text { Repeatability of } \\
\text { the water } \\
\text { permeability test } \\
\text { proposed }\end{array}$ & $\begin{array}{l}\text { To verify the stability of } \\
\text { the water permeability } \\
\text { test proposed repeating } \\
\text { the measures at different } \\
\text { ages several times }\end{array}$ & 6 specimens & - \\
\hline $\begin{array}{l}\text { 4.3.2 Effect of } \\
\text { intermediate } \\
\text { water } \\
\text { permeability } \\
\text { tests in concrete }\end{array}$ & $\begin{array}{l}\text { To study if the } \\
\text { performance of water } \\
\text { permeability tests at } \\
\text { different ages could } \\
\text { affect the permeability } \\
\text { measure. This also will } \\
\text { help to estimate the } \\
\text { needed healing time. }\end{array}$ & $\begin{array}{l}7 \text { specimens with } \\
\text { water permeability } \\
\text { tests at } 0,14,28,42 \\
\text { and } 56 \text { days } \\
7 \text { specimens } \\
\text { analyzing initial/final } \\
\text { water permeability } \\
14 \text { specimens in total }\end{array}$ & $\begin{array}{l}\text { 4.3.3 Precracking } \\
\text { age effect in } \\
\text { concrete }\end{array}$ \\
\hline $\begin{array}{l}\text { 4.3.3 Precracking } \\
\text { age effect in } \\
\text { concrete }\end{array}$ & $\begin{array}{l}\text { To study the influence of } \\
\text { the precracking age in } \\
\text { healing in terms of water } \\
\text { permeability, performing } \\
\text { intermediate tests and } \\
\text { only initial/final tests. }\end{array}$ & $\begin{array}{l}\text { Same as previous } \\
\text { row, plus } 6 \\
\text { specimens } \\
\text { precracked at the age } \\
\text { of } 2 \text { months }\end{array}$ & $\begin{array}{l}4.3 .2 \text { Effect of } \\
\text { intermediate } \\
\text { water } \\
\text { permeability tests } \\
\text { in concrete }\end{array}$ \\
\hline $\begin{array}{l}\text { 4.3.4 Internal } \\
\text { permeability }\end{array}$ & $\begin{array}{l}\text { To verify visually and } \\
\text { with water permeability } \\
\text { tests if healing is } \\
\text { produced in the interior } \\
\text { of concrete specimens. }\end{array}$ & $\begin{array}{l}26 \text { specimens, } 7 \\
\text { control, } 7 \text { with } 2 \% \text { of } \\
\text { CA type A, } 6 \text { with } 2 \% \\
\text { of CA type B and } 6 \\
\text { with } 4 \% \text { of CA type B }\end{array}$ & \\
\hline
\end{tabular}

\subsubsection{Repeatability of the water permeability test proposed}

An experimental study was performed to check the repeatability of the proposed water permeability test and to verify the potential of the "humidity chamber" healing condition as a non-healing exposure. The concrete composition used in this study consists of water/cement ratio of 0.45 and with cement content of $350 \mathrm{~kg} / \mathrm{m}^{3}$, achieving strength class of C45/55 (Table 4-5). The maximum size of aggregate used was $12 \mathrm{~mm} .40 \mathrm{~kg} / \mathrm{m}^{3}$ of steel fibers (Dramix RC 65/35 BN) were added to control crack width during the precracking and healing stages.

Specimens were precracked to achieve 0.15 to $0.40 \mathrm{~mm}$ crack widths at the age of 2 days, and they were tested six times with the aforementioned method after precracking and at 7 , 14 and 28 days old. When not tested, specimens were stored in a humidity chamber. The duration of the test was set at 5 minutes for small cracks (around 0.10-0.20 mm) and 1 minute for medium-sized cracks (around 0.30-0.40 mm). 
Chapter 4. Validation of the methodologies for the evaluation of self-healing

\begin{tabular}{cc}
\hline Material $\left(\mathbf{k g} / \mathbf{m}^{\mathbf{3}}\right)$ & Control \\
\hline Cement II/A-L 42.5 R & 350 \\
Water & 157.5 \\
Gravel (4-12 mm) & 950 \\
Natural sand & 899 \\
Steel fibers & 40 \\
Limestone powder & 50 \\
Crystalline Admixture & -
\end{tabular}

Table 4-5. Mixture proportionsused for the tests.

Fig. 4-14 shows the different water flow values obtained, corresponding to different initial crack widths. It shows the stability of the results of the permeability test proposed in this work. Higher variations were found for specimens with larger initial water flow and a slowly decreasing trend was detected, especially for initial and 7 days permeability. The first measurement of each series shows higher permeability, and in it can be showing that there is a saturation of the crack during the first two measurements.

\section{Specimens stored 0 days}

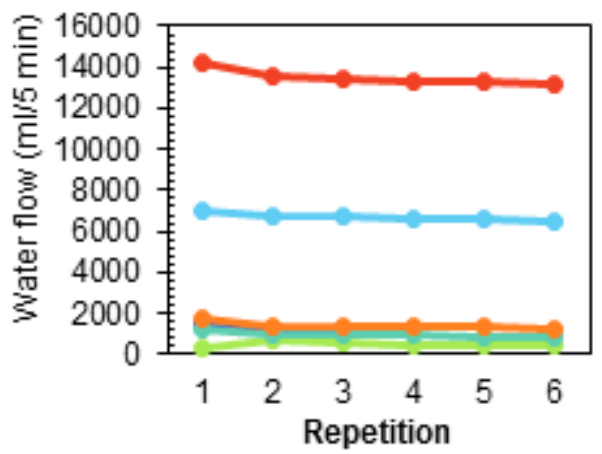

Specimens stored 14 days

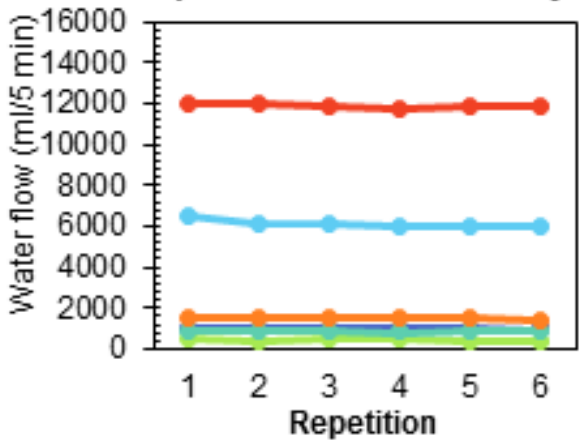

Specimens stored 7 days

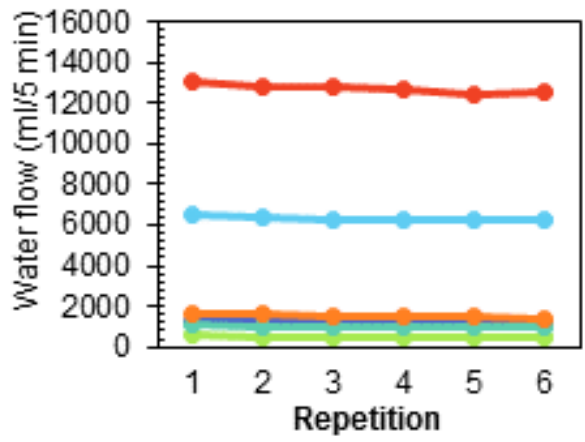

Specimens stored 28 days

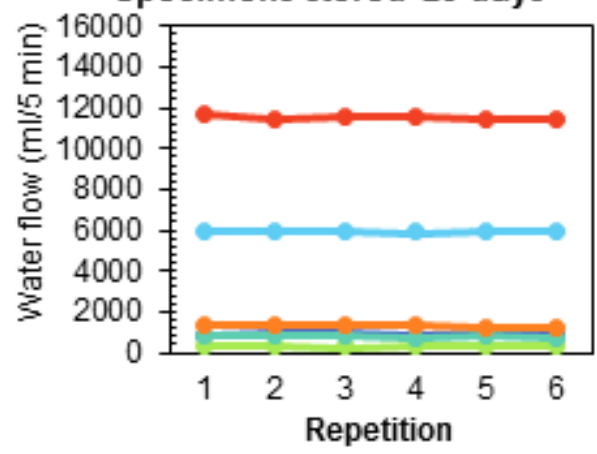

$\multimap$ Spec. $1 \multimap$ Spec. $2 \multimap$ Spec. $3 \multimap$ Spec. $4 \multimap$ Spec. $5 \multimap$ Spec. 6

Fig. 4-14. Repeatability of the high-pressure water permeability test. Each color corresponds to one different specimen. 
The variability of the repeated measurements was analyzed to see the influence of the water inside the crack during the test. These variations, calculated as per equation 4.1, are generally under 5\% (as displayed in Fig. 4-15), and the highest stability comes for the fourth and fifth measures.

$$
\Delta \varepsilon(\%)=\frac{Q_{n}-Q_{n+1}}{Q_{n}} \times 100
$$

\section{Average and std. Dev of the measurement vatiation}

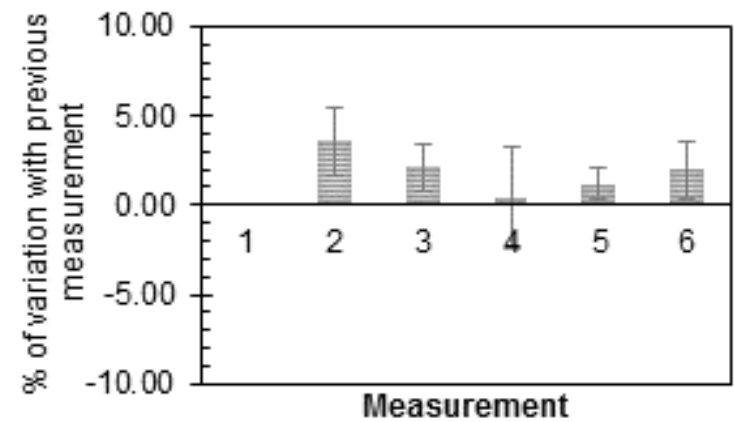

Fig. 4-15. Average variations of one water permeability measurement with respect to the previous.

These specimens were stored at humidity chamber, showing no visual closing of the crack and almost none variation of permeability. This variation was a slight and progressive decrease of water permeability which could be produced by autogenous healing of the crack by the continuing hydration in a high humidity exposure or by loose particles in the crack. But this effect is marginal, since it allows to discriminate specimens with larger and smaller cracks among themselves. Therefore, the method proposed in this work has good stability and repeatability, which is a good indicative of the method. A bad lateral sealing can produce a weak point for performing the test, but once a good sealing procedure is established, the proposed method is easy to implement in concrete laboratories.

\subsubsection{Effect of intermediate water permeability tests in concrete}

Using intermediate tests to evaluate water permeability can potentially affect the results, due to handling of the specimens or entrance of dust inside the crack. A specific study was performed to determine the effect of the intermediate tests on the final result. This was one of the first tests performed chronologically, and because of that the concrete composition used is similar to the one shown in Table 4-5, but with $20 \mathrm{~kg} / \mathrm{m}^{3}$ more of fibers, as displayed in Table 4-6. In later experimental campaigns the amount of fibers was reduced to diminish crack branching. 


\begin{tabular}{cc}
\hline Material $\left(\mathbf{k g} / \mathbf{m}^{3}\right)$ & Control \\
\hline Cement II/A-L 42.5 R & 350 \\
Water & 157.5 \\
Gravel (4-12 mm) & 957 \\
Natural sand & 870 \\
Steel fibers & 60 \\
Limestone powder & 50 \\
Crystalline Admixture & -
\end{tabular}

Table 4-6. Mixture proportions used for the tests.

Two groups were analyzed, one, in which intermediate water permeability tests were performed each 14 days, and the second in which the tests were only performed at time 0 and after 56 days of healing. The healing exposure of choice for this study was Water Contact, with a water layer of $2 \mathrm{~cm}$ on the top of the specimen, which was initiated at the age of 3 days from casting (time 0 of healing).

The results in Fig. 4-16 show that the biggest variation happens in the first 14 days, but there is still reaction during the following days. The results of this test showed similar trend for specimens of both groups, but those that underwent intermediate water permeability tests were more likely to have complete healing, with exactly zero water flow at the end of the healing period.

With intermediate tests

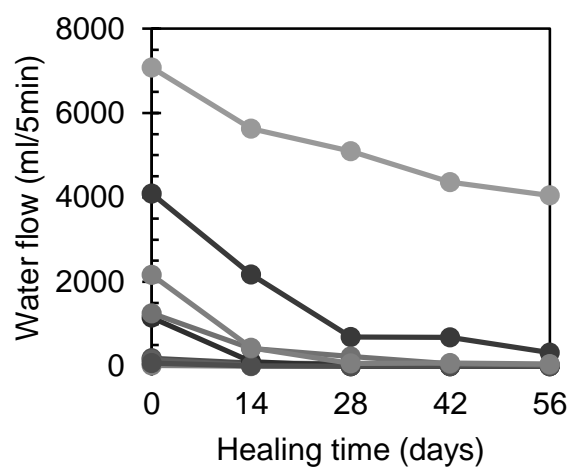

Initial and final tests

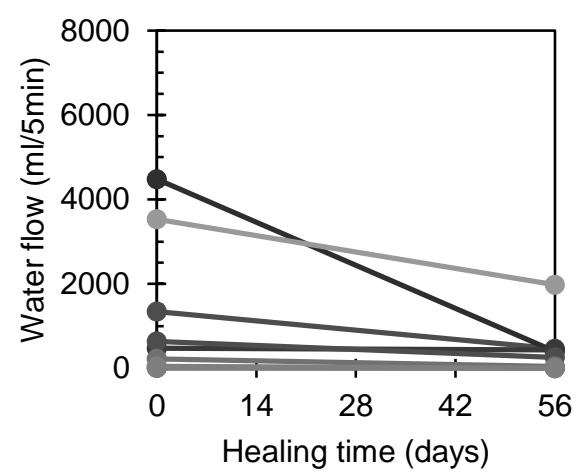

Fig. 4-16. Water permeability evolution with time for specimens using intermediate tests (left) or only initial-final tests (right).

This indicates a cross-effect of having these intermediate tests, which can be considered of lesser influence depending on the objective of the campaign to perform. This is also supported with the results obtained in the previous section, in which water permeability decreased (at a very low rate) with each test. Therefore, if the expected values have small range of results, it will be convenient to avoid the use of multiple tests in a same specimen. 
The studies reported in the literature have not analyzed this effect and use frequently intermediate tests, even for analyzing autogenous healing with mixes of similar composition.

\subsubsection{Precracking age effect in concrete}

This study compares the healing efficiency for an early age crack and a mature crack, comparing one produced at 2 days and put into the healing exposure the third day with cracks produced at the age of 2 months (56 days), and similarly, put into the healing exposure the day 57 from casting. The mixture proportions used for this work is the same as used in Table 4-6, and the healing exposure of choice for this study was Water Contact, as well.

Fig. 4-17 and Fig. 4-18 show the results obtained with the water permeability test for the selected small-sized cracks, approximately up to $0.22 \mathrm{~mm}$. Fig. 4-17 shows the evolution of the water permeability of specimens with early age and mature cracks when performing intermediate water permeability tests, and shows a continuously decreasing evolution of water flow, even for mature cracks, but with much higher rates for the young cracks.

Precracked at 3 days

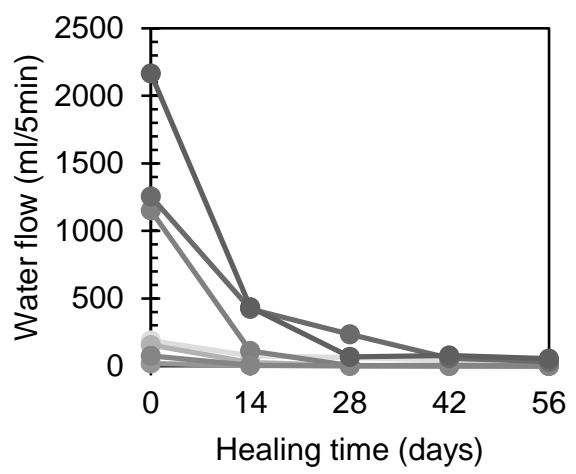

Precracked at 2 months

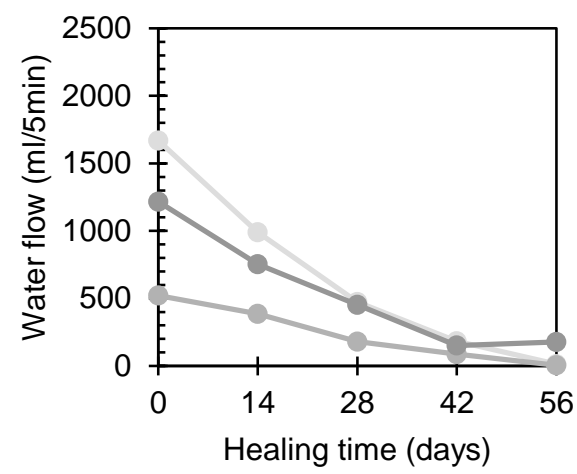

Fig. 4-17. Water permeability evolution with time for specimens precracked at the age of 3 days (left) and at the age of 2 months (right), when performing intermediate water permeability tests.

However, Fig. 4-18, shows the evolution when performing only initial and final water permeability tests, with that mature cracks showing less water flow reduction compared with its equivalent with intermediate tests. Regarding young cracks, the final water flow reached is similar in both cases. 
Precracked at 3 days

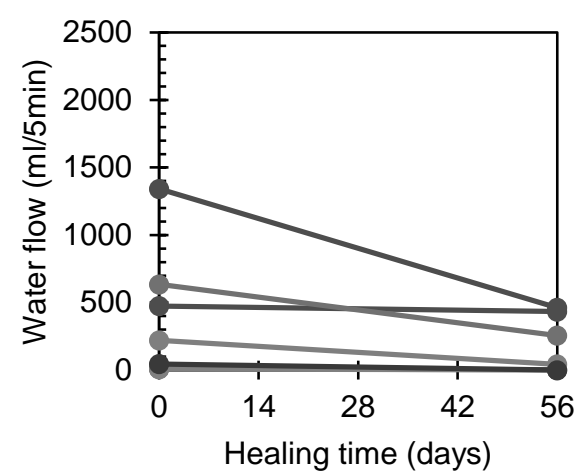

Precracked at 2 months

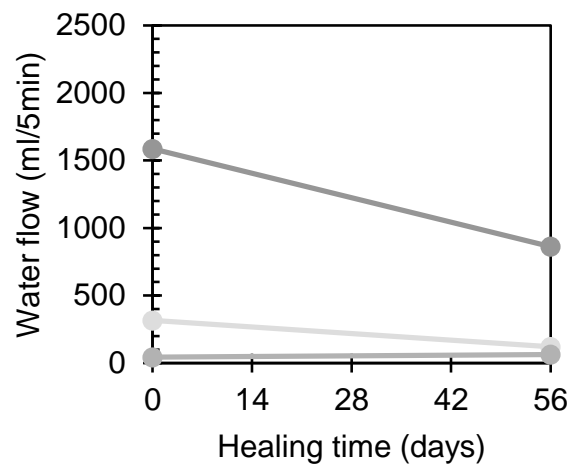

Fig. 4-18. Water permeability evolution with time for specimens precracked at the age of 3 days (left) and at the age of 2 months (right), when performing only initial and final water permeability tests.

The results reported by Edvardsen (1999) for specimens precracked at the age of 28 days showed that autogenous healing mostly took place in the first 5-7 days of water immersion. The results obtained in this experimental campaign confirm that most of the reaction takes place in the first 14 days when the cracks are young (2-3 days). However, for older cracks the evolution of the water flow reduction is slower but at a more constant rate. This is coherent with the results obtained by Nishiwaki et al. (2012), who reported the further continuation of reactions even after 20-30 days of exposure.

\subsubsection{Internal permeability}

This campaign aims to verify if healing is a surface phenomenon, or if there is also internal healing. Two tests were planned to analyze internal healing. For this purpose, concrete specimens completely healed in terms of water permeability and unhealed specimens were compared.

Two different tests were performed to check:

- The presence of precipitates in the internal crack. Specimens were cut with a transversal cut as displayed in the diagram of Fig. 4-19 left.

- The internal water permeability after removing internal the upper part of the specimens with cuts parallel to the plane surface (Fig. 4-19 right), of approx. $1 \mathrm{~cm}$ width.

The cut process was carried out with a circular saw for concrete and not with splitting test because of the presence of steel fibers. 

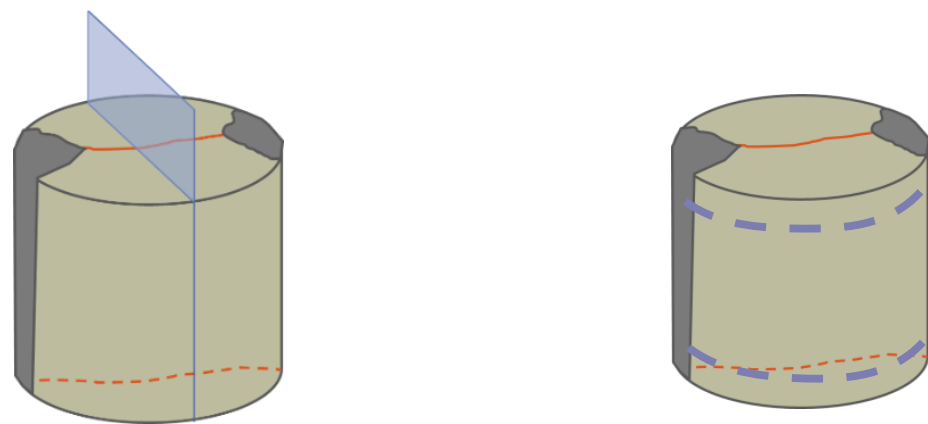

Fig. 4-19. Cuts performed in concrete specimens to verify internal healing.

The first test showed that the crystal precipitation occurs only up to $0.5-1 \mathrm{~cm}$ depth, which can be seen in the disks and in the transversal cuts (Fig. 4-20). However, the cut process could also have detached the crystals inside the crack, if any.

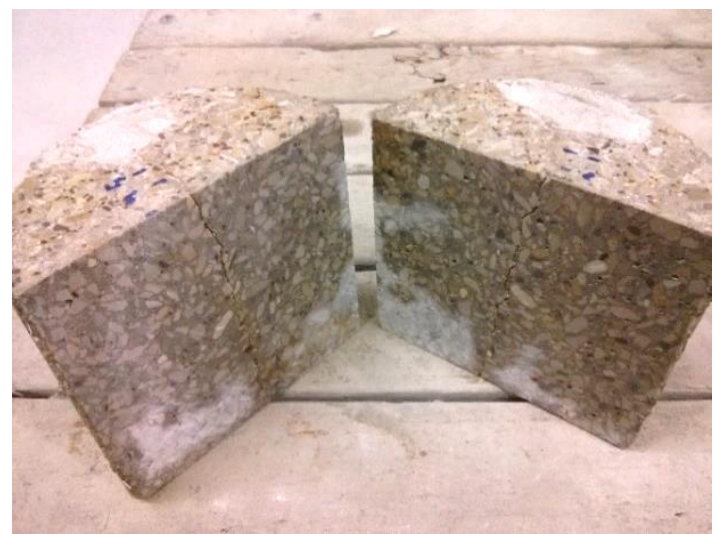

Fig. 4-20. Specimen with a transversal cut showing no precipitates in the internal part of the crack.

The formation and type of precipitates suggested the need of removing the external disks where the precipitates were produced, in order to check if the healing processes were able to heal the crack in-depth or only produced a surface sealing. After that, the internal cylinder has been tested to the same water permeability test.

For the internal water permeability test 26 specimens were tested. These specimens were precracked at the age of 2 days, put to heal at the age of 3 days and were let to heal for 6 months under water immersion at $30^{\circ} \mathrm{C}$. Most of them showed complete or perfect healing in terms of water permeability (Fig. 4-21).

Fig. 4-22 shows the results of internal permeability obtained. Control and CA type A had better internal healing, in the case of control specimens up to water permeability values of around $7000 \mathrm{ml} / 5 \mathrm{~min}$ (around $0.35 \mathrm{~mm}$ ). However, specimens with the CA type B had bad internal healing, even though increasing their dosage improved the internal healing. This graph shows that control specimens are more scattered than specimens with CA type A, indicating slightly worse healing. This test shows by cutting the external disks that the 
healing process has a great component of a surface process and that the crystalline admixture type $\mathrm{A}$ has better internal healing response that type $\mathrm{B}$ (see Table 3-2 for checking the composition of these two CA).

Perfect healing after 6 months in WI_30

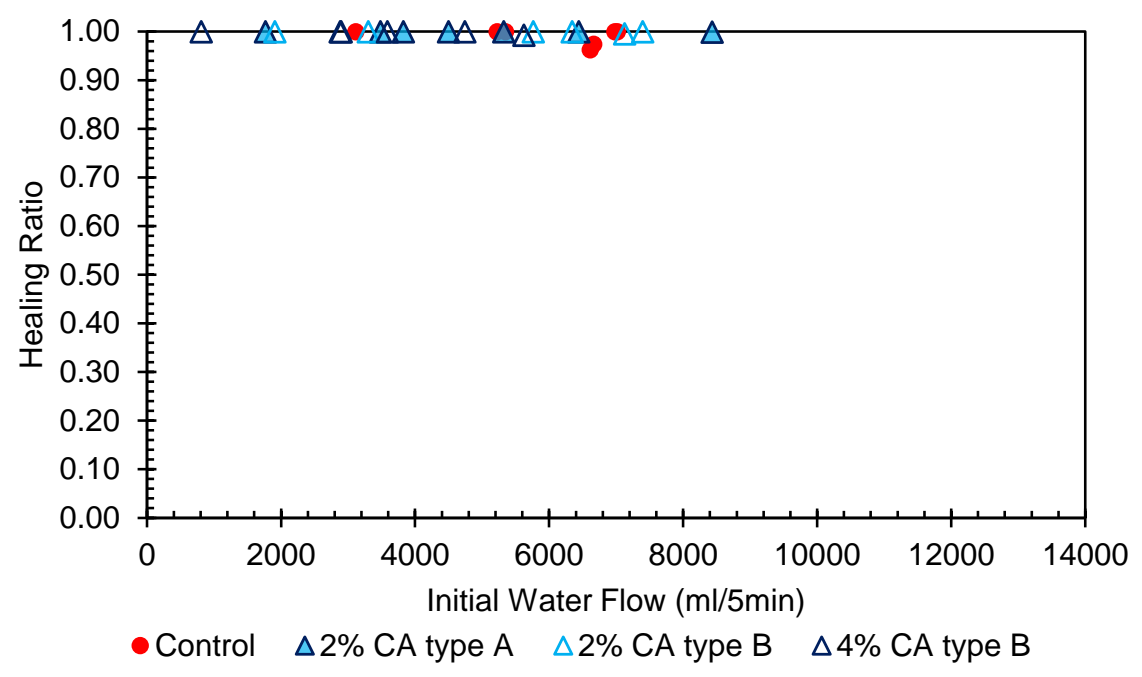

Fig. 4-21. Healing Ratios obtained in specimens with perfect healing.

Internal healing after cutting

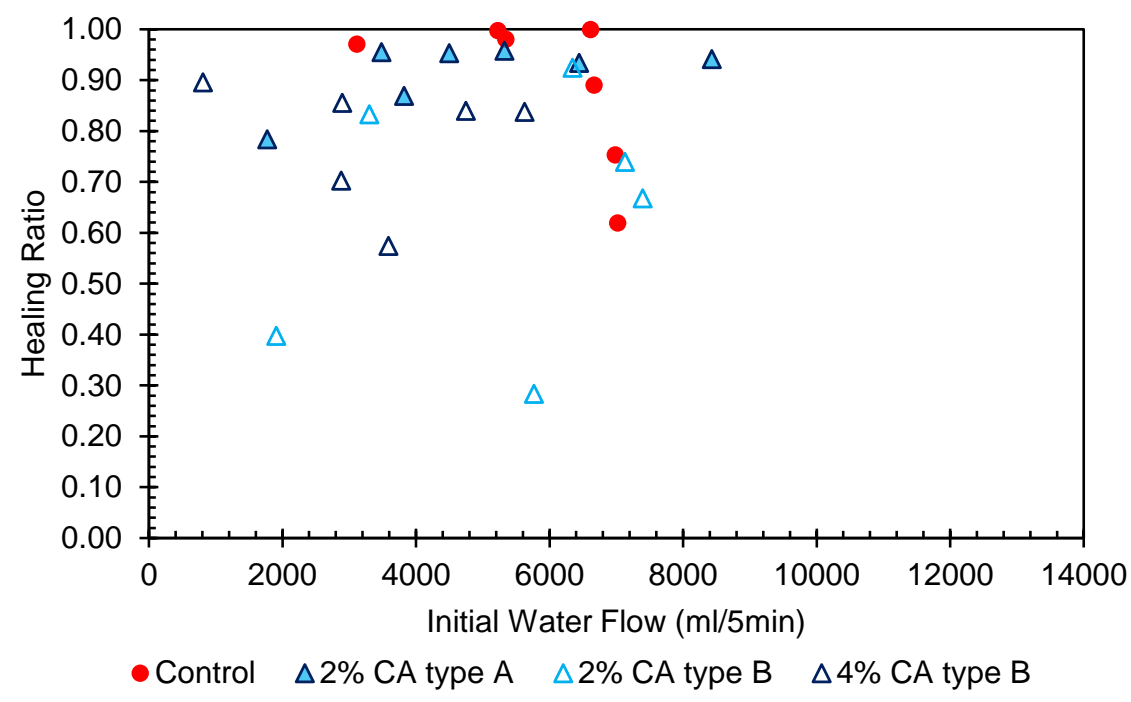

Fig. 4-22. Internal healing ratio by water permeability. 


\subsection{Relation between crack closing and permeability tests}

This Section includes a specific study of relation between crack geometrical parameters and water flow. The main goal is to find an appropriate parameter for measuring crack closing using as the reference test the results obtained by water permeability. For this purpose, 13 concrete specimens without CA and 12 with CA were analyzed, using their initial and final values of water permeability and crack measures, then 26 and 24 test results were analyzed. These specimens were also used in Section 5.2 "Influence of several parameters on selfhealing by means of crack closing and water permeability".

The concrete composition used in this study is the same used in previous campaigns (see Table 4-5), and consists of water/cement ratio of 0.45 and with cement content of 350 $\mathrm{kg} / \mathrm{m}^{3}$, achieving strength class of $\mathrm{C} 45 / 55$. The maximum size of aggregate used was 12 $\mathrm{mm} .40 \mathrm{~kg} / \mathrm{m}^{3}$ of steel fibers (Dramix RC 65/35 BN) were added to control crack width during the precracking and healing stages.

In this study four crack geometrical parameters are compared using as reference water permeability results. The four parameters are those described in Section 3.2:

- $\quad w_{\max }$, maximum crack width: by means of graphic software, the maximum crack width along the whole crack length is determined, in millimeters.

- $\quad w_{\text {avg }}$, average crack width: by means of graphic software, crack width (in millimeters) is determined in five fixed positions and averaged.

- $A_{\text {est }}$, crack area estimated from estimated from average crack width $\mathrm{w}_{\text {avg: }}$ using the five measures of crack width and multiplying by their associated lengths, in squared millimeters.

- $A_{p x}$, crack area measuring black pixels: by using graphic software, black pixels in the image are counted, which indicate crack area.

When representing water flow versus the four crack geometry parameters obtained from image analysis, the best correlations were obtained from the relation between water flow and the $A_{\text {est }}$ (Fig. 4-24) and with the averaged crack width $w_{\text {avg }}$ (Fig. 4-23). The chosen trend lines are cubic functions depending on the crack geometry parameter: as explained from the literature, the water flow in a cracked specimen depends on the third order power of the crack width (Edvardsen, 1999).

On the other hand, the correlation between water flow and $w_{\max }$ (Fig. 4-25) and $A_{p x}$ (Fig. 4-26) were highly dispersed and therefore these crack geometry parameters are proved to be worse indicators of the level of damage of the cracked specimens and the resulting selfhealing. As a matter of fact, it can be observed that the measure of black pixels achieved the worst results. There are two possible reasons for this behavior: a) the three-dimensional effect of the interior part of cracks, which makes crack pixels turn grey in the photographs while still being part of the crack; and b) the small interferences of black pixels outside the crack, though they were cleaned for minimizing this effect. The influence of these two drawbacks of this method could potentially be decreased by optimizing the parameters of the post-processing stage. This point has not been further studied because of the long processing time associated with the calculation of $A_{p x}$. 
Chapter 4. Validation of the methodologies for the evaluation of self-healing

For the two best methods, polynomial cubic trend lines were calculated by applying the boundary conditions of zero flow in correspondence of zero damage and horizontal tangent at zero flow. Adjusted R-squared $\left(R^{2} a d j\right)$ was used in order to evaluate the goodness of fit of the model. The fitted equations obtained for these two cases are displayed in Table 4-7.

Water flow - averaged crack width

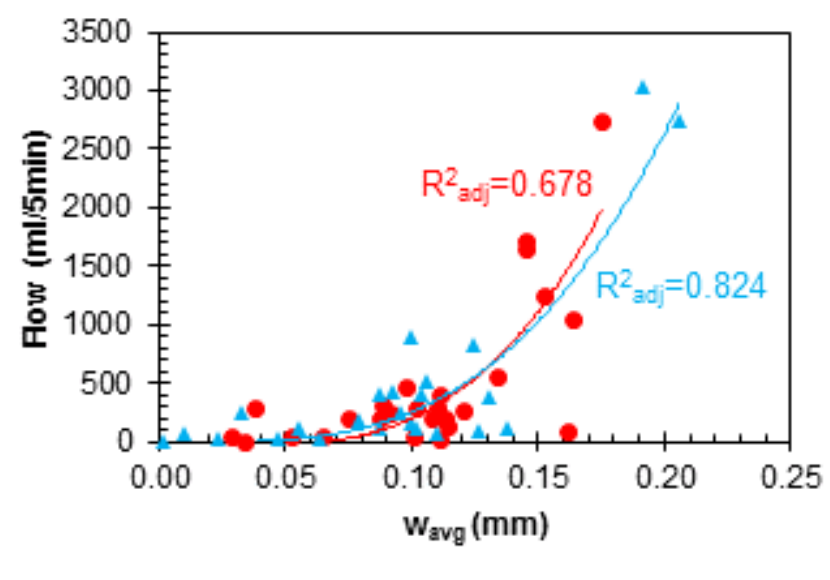

- Control $\triangle$ CA type A

Fig. 4-23. Relation between water flow and average crack width wavg.

Water flow - crack area

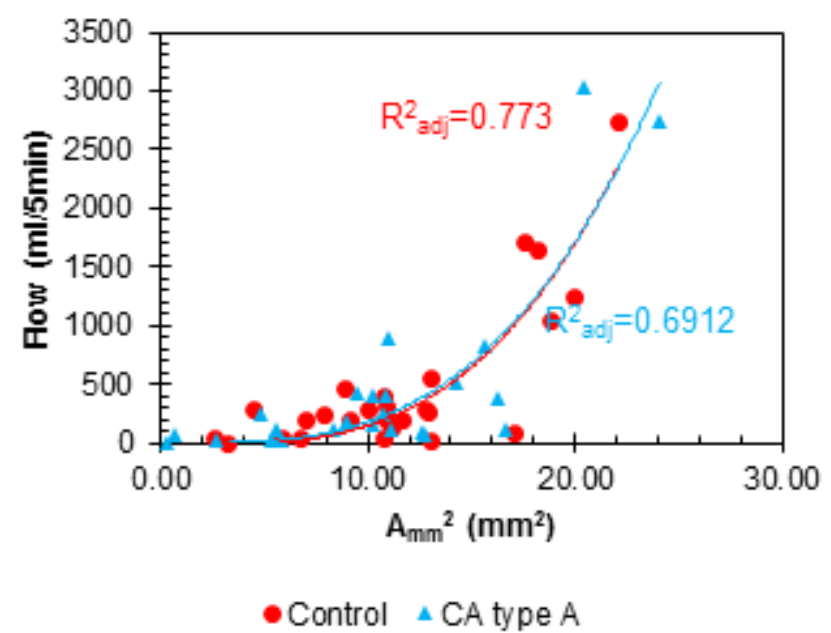

Fig. 4-24. Relation between water flow and estimated crack area $A_{\text {est. }}$.

\begin{tabular}{ccc}
\hline & Control & CA \\
\hline Wavg & $\mathrm{Q}=593900 \cdot \mathrm{w}^{3}-39700 \cdot \mathrm{w}^{2}$ & $\mathrm{Q}=405100 \cdot \mathrm{w}^{3}-15130 \cdot \mathrm{w}^{2}$ \\
\hline A est & $\mathrm{Q}=0.2828 \cdot \mathrm{A}^{3}-1.38 \cdot \mathrm{A}^{2}$ & $\mathrm{Q}=0.2529 \cdot \mathrm{A}^{3}-0.7657 \cdot \mathrm{A}^{2}$ \\
\hline
\end{tabular}

Table 4-7. Fitted polynomial cubic trend lines for the two best methods. 


\section{Water flow - maximum crack width}

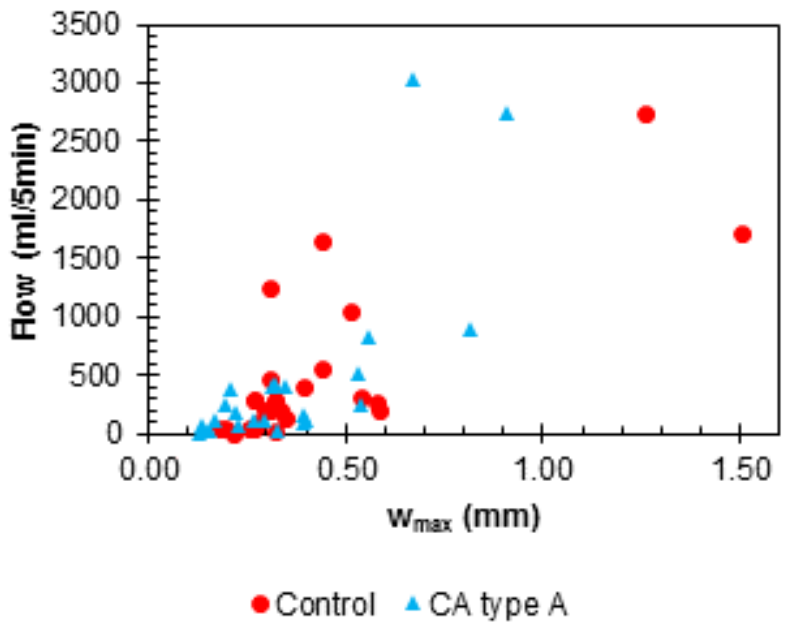

Fig. 4-25. Relation between water flow and maximum crack width $w_{\max .}$

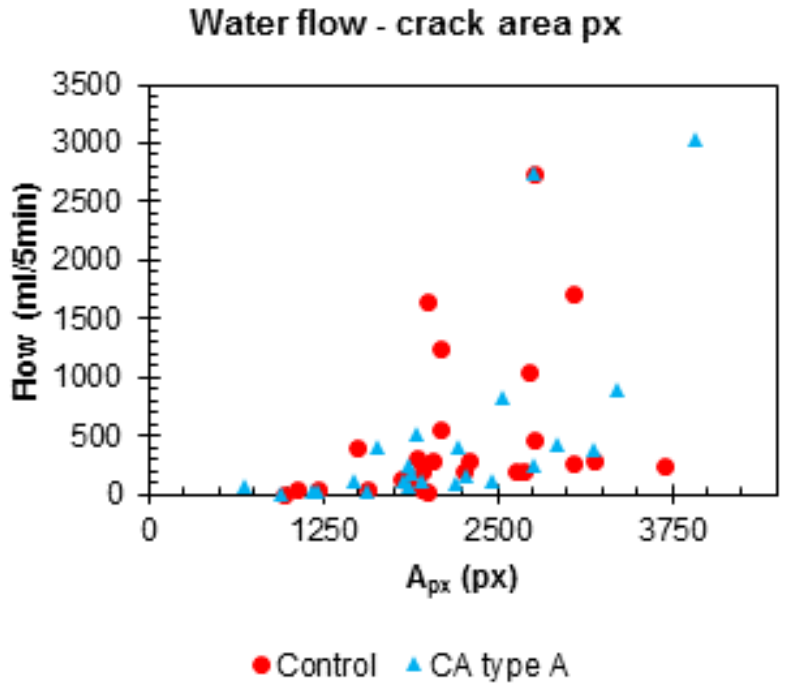

Fig. 4-26. Relation between water flow and the number of black pixels $A_{p x}$.

In each specimen two cracks were formed, on the top and the bottom surface. When choosing the value of the crack geometry parameter to study its relationship with water flow, several options could be considered: the value of the parameter for the top/bottom crack, the minimum or the maximum, the average value, etc. The minimum crack and the 
averaged crack were expected to be the best parameters to represent the damage comparing with the permeability results, the first option because the minimum section may restrict water flow and the latter because it is an estimation of the $3 \mathrm{D}$ volume of the crack considering it as a pyramidal frustum. The results in Fig. 4-23 were represented using the averaged result from both top and bottom surface cracks. Other relations were also analyzed, and they showed notably worse results for the cases of choosing the minimum, and maximum value of cracks, for one of the best parameters, $A_{\text {est }}$. Choosing the top or the bottom crack as parameter did not showed any stable trend. Very similar results were achieved when analyzing the averaged crack width parameter $w_{\text {avg }}$.

In a more complete campaign, the relation between initial water flow from the permeability test and $w_{\text {avg }}$ was verified. The dispersion graph Fig. 4-27 displays the values of crack width versus the corresponding values of water flow. The dispersion in the correlation between water flow and crack width could be caused by different geometries of the in-depth volume of the crack, i.e. its tortuosity. The final values experienced notably higher dispersion, which indicates a weaker relation between the final water flow and the final crack width. Moreover, self-healing could be happening inside the specimen yet have no visible effect on the surface crack, which could be also increasing the dispersion of the results. Therefore, the following curves were plotted considering only the initial values of water flow and crack width.

This main interest in this correlation is to compare the values of healing for permeability and crack closing obtained for specimens with similar damage, that is, with approximately equivalent water flow and crack width, rather than to find an exact relationship between both parameters.

\section{Relation between water flow and crack width}

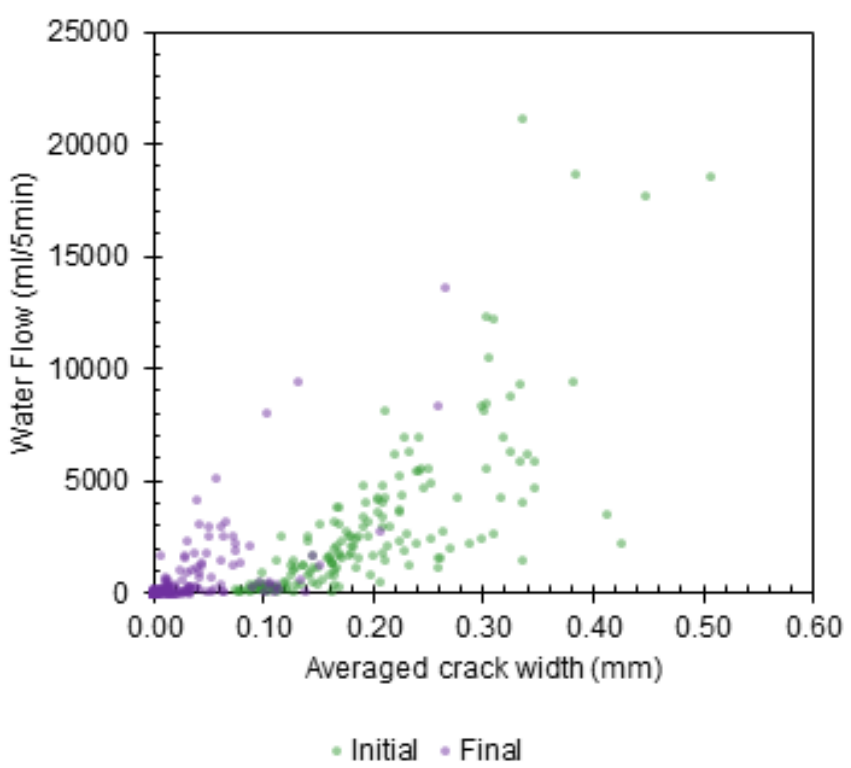

Fig. 4-27. Comparison of initial and final (after 42 days) values of water flow versus crack width. 
To better estimate the relation between water flow and crack width, only initial values were considered (169 values). From the literature, it is accepted that the relation follows a cubic expression with only the cubic coefficient (Edvardsen, 1999). Edvardsen proposed a model based on Poiseuille Law, which is expressed in equation (eq. 4.1), for water at $20^{\circ} \mathrm{C}$, viscosity $v=\eta / \rho=1.00 \mathrm{~mm}^{2} / \mathrm{s}$ ) and a visible crack length of 1 meter; where $\mathrm{q}_{0}$ is the water flow per meter length of crack, I is the hydraulic gradient in meters of water head per meter, $w_{\text {avg }}$ is the mean value of crack width and $k_{t}$ is a correcting parameter for temperature.

$$
q_{0}\left(\frac{\text { liters }}{m}\right)=740 * I * w_{\text {avg }}^{3} * k_{t}
$$

This expression can be adjusted to the parameters of the present research by changing units and the length of the crack (considered as $75 \mathrm{~mm}$ ), resulting in the expression (eq 4.2).

$$
Q \text { (liters) }=740 * \frac{20}{0.15} * w_{\text {avg }}^{3} * 1 * 0.075
$$

The obtained experimental results of water flow and averaged crack width in this research follow the trend of the theoretical predictions given by eq. 4.2, as displayed in Fig. 4-28, but with much lower values of water flow for their corresponding crack width. Fig. 4-28 also shows the cubic trendline for the initial values obtained in this experimental campaign. The lower values obtained in this research might be due to the presence of fibers which could help blocking water flow inside the crack, as reported by Lawler, et al. (2003). In fact, the values obtained experimentally do not fit Edvarsen's curve, showing a coefficient of determination $\mathrm{R}^{2}$ of 0.01246 .

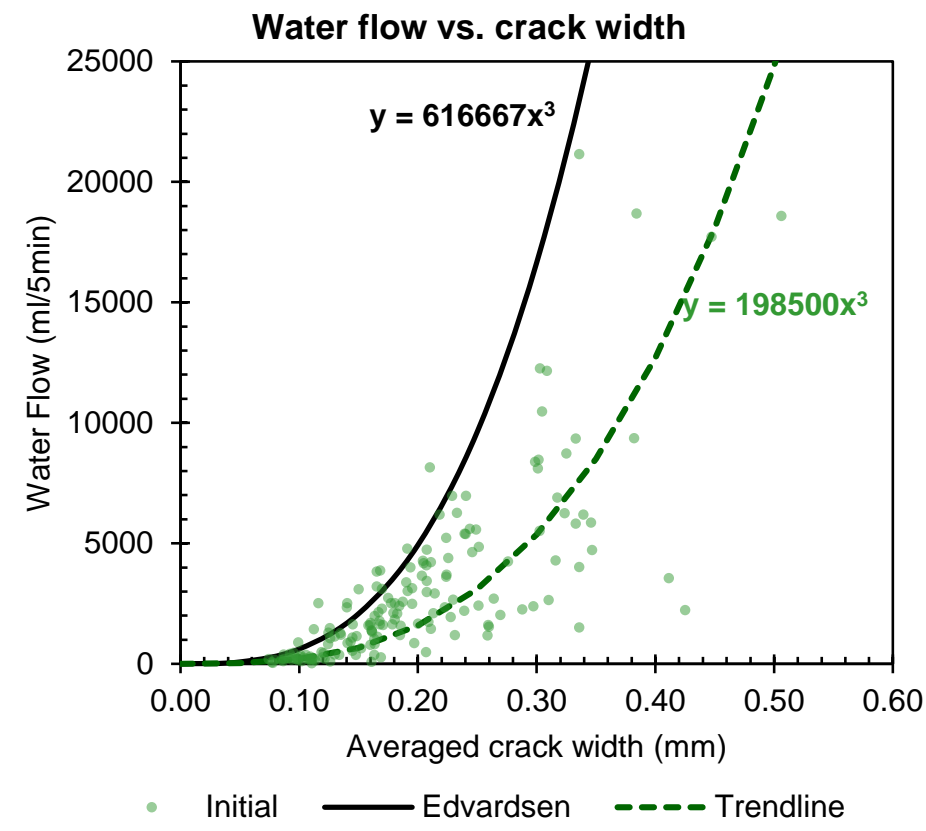

Fig. 4-28. Comparison water flow and crack width relation obtained with the results from (Edvardsen, 1999). 
Fig. 4-29 plots the values of initial water flow from the permeability test versus the corresponding initial average crack width of specimens from the present study, as well as the computed regression curves. The applied boundary condition is to adjust to a cubic polynomial curve with only the cubic coefficient. Two robustness methods were used to minimize the influence of outliers in the regression curve, Least Absolute Residuals (LAR) and Bisquare, and compared with the regression obtained when no outlier influenceminimization method was employed. The three curves were quite similar, but with different values of the coefficient of determination $\left(\mathrm{R}^{2}\right)$ : 0.95 for the LAR curve, 0.77 for the Bisquare curve and 0.47 when using no robustness model.

These trendlines were used to estimate several theoretical values of initial water flow for each value of initial crack width. The arrows in Fig. 4-29 indicate the limit values that will be used to analyze the following results. Thus, an initial damage of crack width $0.30 \mathrm{~mm}$ will be equivalent to a result in the permeability test of around $5000 \mathrm{ml} / 5 \mathrm{~min}$, while an initial damage of crack width $0.40 \mathrm{~mm}$ will be equivalent to a of around $13000 \mathrm{ml} / 5 \mathrm{~min}$. for the discussion.

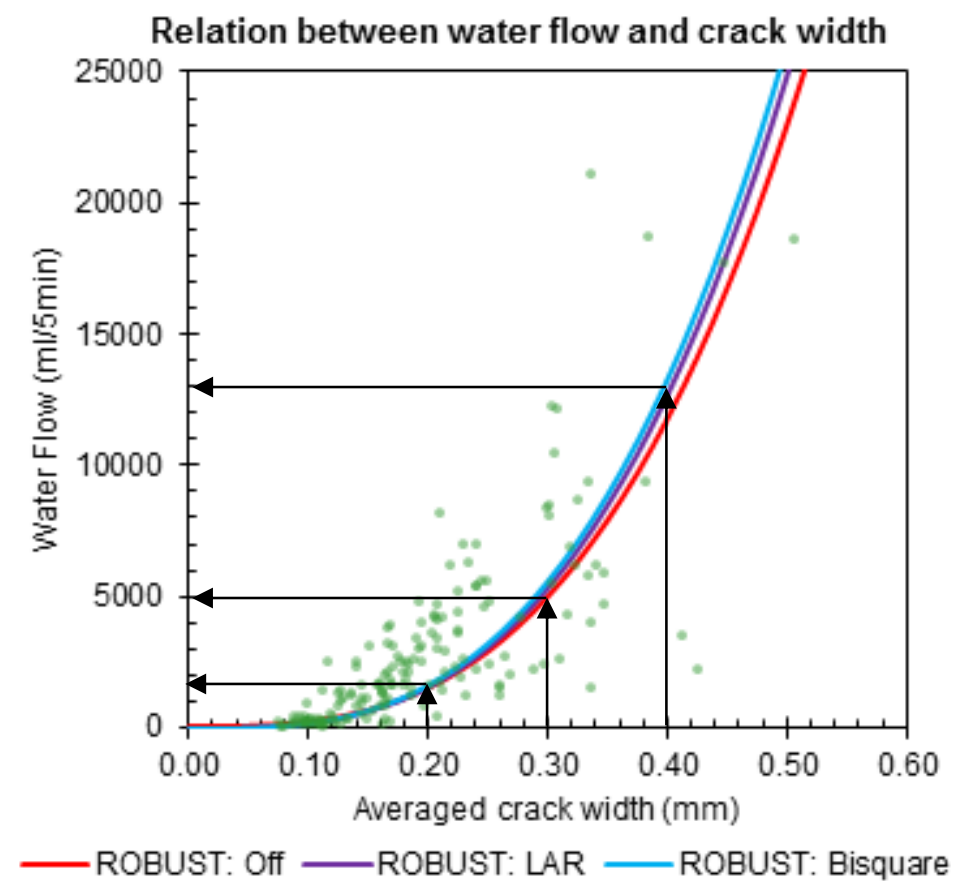

Fig. 4-29. Initial crack width versus initial water flow with differently-adjusted trendlines.

This relation between water flow and crack width indicates that the evaluation of water flow could be considered as an indirect way to evaluate the crack volume, since the internal tortuosity of the crack in the interior of the specimen will condition the ability of water to pass through the specimen. 
Even though the healing capacity of specimens was inverse related with damage suffered, in the literature there is no clear agreement between the limit values of initial damage to achieve complete healing in terms of permeability and crack closing. In this research, average crack widths up to around $0.40 \mathrm{~mm}$ have been analyzed, then, the limits for the water permeability graphs will be fixed at $14000 \mathrm{ml} / 5 \mathrm{~min}$ and for the crack closing graphs to $0.50 \mathrm{~mm}$, to cover all the representative values.

\subsection{Mechanical properties}

This section discusses the use of different reference specimens for the mechanical properties and the appropriateness of several expressions to evaluate self-healing in terms of peak load, stiffness and area. Table 4-8 shows the list of subsections of the thesis addressing the evaluation of mechanical regain, indicating its objective, the size of the program and number of specimens analyzed. The specimens used in this study were used as part of the control specimens without CA of the section "5.3 Mechanical recovery" which addresses the influence of CA in the mechanical recovery of concrete, in subsection 5.3.1 for optimum healing conditions. Additionally, Subsection 4.5.3 covers additional considerations for the analysis of healing by means of mechanical recovery.

\begin{tabular}{llll}
\hline Subsection & Objective & $\begin{array}{l}\text { Size of the } \\
\text { experimental } \\
\text { program }\end{array}$ & $\begin{array}{l}\text { Related } \\
\text { subsections }\end{array}$ \\
\hline $\begin{array}{l}\text { 4.4.1 Reference } \\
\text { specimen and } \\
\text { expression to } \\
\text { evaluate the } \\
\text { recovery }\end{array}$ & $\begin{array}{l}\text { Compare different types } \\
\text { of reference specimens } \\
\text { (precracked and healed } \\
\text { in HC or uncracked }\end{array}$ & $\begin{array}{l}\text { 12 specimens } \\
\text { accompanying spc.) }\end{array}$ & $\begin{array}{l}\text { 5.3.1 Effect of CA } \\
\text { in optimal } \\
\text { conditions }\end{array}$ \\
\hline $\begin{array}{llll}\text { 4.4.2 Effect of } \\
\text { fiber content }\end{array}$ & $\begin{array}{l}\text { To compare the effect } \\
\text { of the reinforcement in } \\
\text { the evaluation of self- } \\
\text { healing }\end{array}$ & $\begin{array}{l}\text { 12 specimens }(6 \\
\text { with CA, } 6 \text { without } \\
\text { CA, with two levels } \\
\text { of fiber contents) }\end{array}$ & \\
\hline
\end{tabular}

Table 4-8. List of experimental studies performed for the validation of the mechanical recovery.

\subsubsection{Reference specimen and expression to evaluate the recovery}

In this study, steel fiber-reinforced concrete was used to control the post-cracking regime of concrete (composition in Table 4-9). Compressive strength and slump results obtained in this campaign is included because of their relevance on the mechanical properties. The amount of fibers was fixed in $40 \mathrm{~kg} / \mathrm{m}^{3}$ to control the crack opening procedure, avoiding crack branching. The objective was to verify if the matrix is able to recover some extent of mechanical properties, either in terms of strength or in stiffness.

Notched prismatic specimens $(100 \mathrm{~mm} \times 100 \mathrm{~mm} \times 500 \mathrm{~mm})$ were precracked by three point bending test until the cracks reached openings of $0.25-0.30 \mathrm{~mm}$ at the age of 2 days and put in the healing exposure the same day of the precracking stage. Two methodologies have been compared for the analysis of mechanical recovery (Fig. 4-30). First, the recovery of specimens healing under water immersion at $30^{\circ} \mathrm{C}$ was compared in Campaign 1 with 
Chapter 4. Validation of the methodologies for the evaluation of self-healing

that of specimens healed in humidity chamber. Second, specimens healing for 42 days were compared with reference specimens, which were stored under the same healing exposure, precracked and reloaded at the final reloading age (Campaign 2).

\begin{tabular}{cc}
\hline \multicolumn{2}{c}{ Concrete dosage $\mathbf{( k g / \mathbf { m } ^ { 3 } )}$} \\
\hline Cement II/A-L 42.5 R & 350 \\
Water & 157.5 \\
Gravel (4-12 mm) & 950 \\
Natural sand & 899 \\
Steel fibers & 40 \\
Limestone powder & 50 \\
\hline Slump (cm) & 13 \\
Compressive Strength (MPa) & 38.6 \\
\hline
\end{tabular}

Table 4-9. Mixture proportions and its properties.

Healing specimens

$$
\text { Specimens }
$$
to analyze

\section{Reference Campaign 1}

Accompanying
specimens

Reference Campaign 2
Accompanying specimens

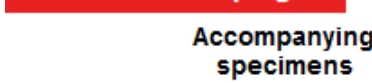

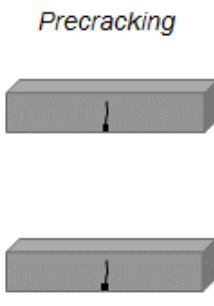

Healing + Maturing

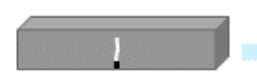

Reloading

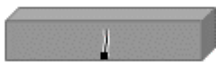

No precracking
Stored at humidity chamber

\section{西}
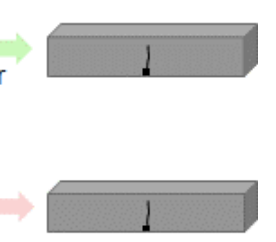

Fig. 4-30. Testing procedure for concrete specimens and both kinds of accompanying specimens.

The number of specimens and ages for each group are summarized in Table 4-10.

\begin{tabular}{|c|c|c|c|}
\hline \multicolumn{4}{|c|}{ Experimental program } \\
\hline \multicolumn{4}{|c|}{ Campaign 1} \\
\hline Exposure & Precracking / Reloading age & Healing time & Specimens \\
\hline Humidity Chamber & 2 days / 58 days & 56 days & 3 \\
\hline Water Immersion $30^{\circ} \mathrm{C}$ & 2 days / 58 days & 56 days & 3 \\
\hline \multicolumn{4}{|c|}{ Campaign 2} \\
\hline Exposure & Precracking / Reloading age & Healing time & Specimens \\
\hline Water Immersion $30^{\circ} \mathrm{C}$ & 44 days / 44 days & 42 days & 3 \\
\hline Water Immersion $30^{\circ} \mathrm{C}$ & 2 days / 44 days & 42 days & 3 \\
\hline
\end{tabular}

Table 4-10. Experimental program for the campaign to analyze reference specimens. 
All specimens healed underwater showed white precipitates in the crack; however, none of them had a new peak in the reloading curve (Fig. 4-31), which confirms that the precipitates did not produce a significant recovery of matrix strength. The reloading curves corresponding to the specimens healing in both humidity chamber and in water immersion, have in all cases an increase of the residual strength (after the peak) compared to that of the precracking curve. On the contrary, reference specimens precracked and reloaded at the same age (bottom left graph) had similar residual strength at precracking and reloading. Therefore, disregarding this effect would confound healing with maturing, especially for early age concrete.
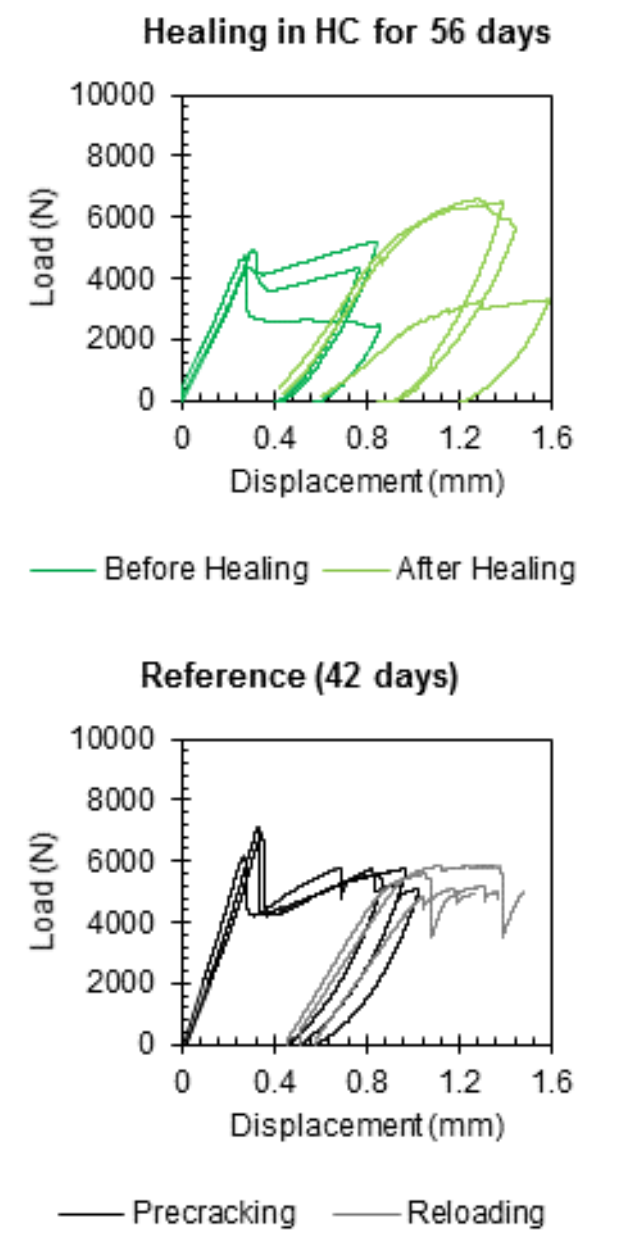

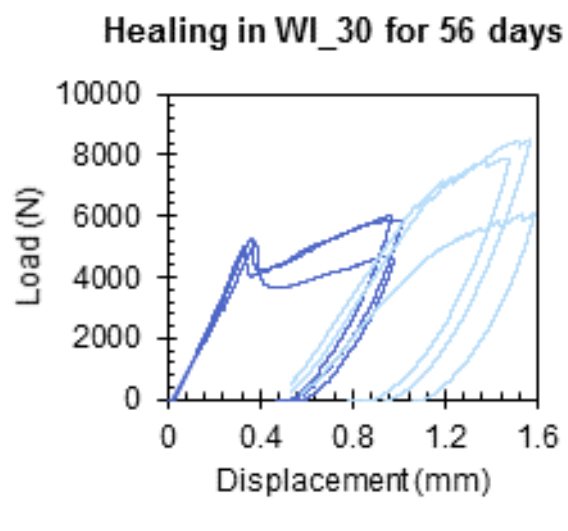

_ Before Healing ___ After Healing

Healing in WI_30 for 42 days

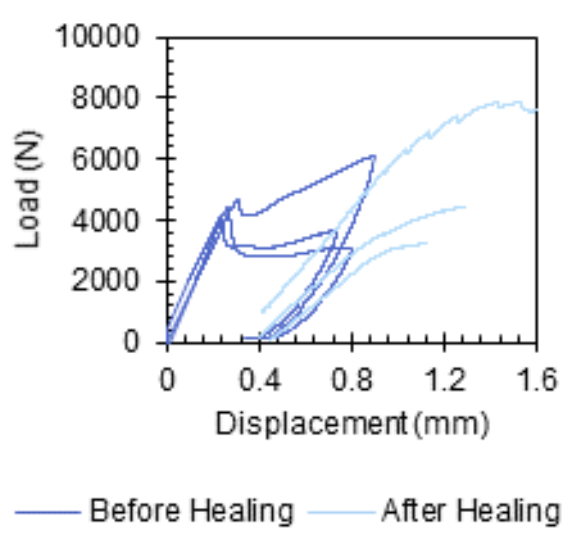

Fig. 4-31. Top row: Load-displacement curves for Campaign 1, specimens healed in humidity chamber (left) and in water immersion at $30^{\circ} \mathrm{C}$ (right). Bottom row: Load-displacement curves for

Campaign 2, reference specimens (left) and healed in water immersion at $30^{\circ} \mathrm{C}$ (right). 
Due to the lack of a new peak load, only the stiffness has been analyzed in this study.

Several expressions to evaluate the stiffness recovery have been compared, using the structure without reference (Table 4-11) and with reference (Table 4-12), using the notation explained in Chapters 2 and 3.

\begin{tabular}{lc}
\hline Concept & Formula of Stiffness Recovery \\
\hline Comparison with its initial values & $K R 1 \%=\frac{K_{2}}{K_{1}} * 100$ \\
\hline $\begin{array}{l}\text { With specimens at Humidity Chamber } \\
\text { (Campaign 1) }\end{array}$ & $K R 2 \%=\frac{K_{2}}{K_{2^{\prime} H C}} * 100$ \\
\hline $\begin{array}{l}\text { With accompanying uncracked spec. } \\
\text { (Campaign 2) }\end{array}$ & $K R 3 \%=\frac{K_{2}}{K_{1^{\prime}}} * 100$ \\
\hline
\end{tabular}

Table 4-11. Formula of Stiffness Recovery without a reference.

Fig. 4-32 top shows the stiffness recovery of specimens by direct comparison with their precracking curve (as per eq. 4.4). Specimens healing for 42 days under water immersion at $30^{\circ} \mathrm{C}$ obtained reloading stiffness of around $40 \%$ of the precracking stiffness, while those healed for 56 days around $65 \%$. Those specimens stored in humidity chamber for 56 days obtained dispersed results between 40 and $65 \%$ of the initial stiffness. Comparing the results obtained for the specimens healed at water immersion at $30^{\circ} \mathrm{C}$, there is a clear improvement between specimens healing for 42 and 56 days, while those specimens stored at humidity chamber for 56 days also achieved comparable results with those healed the same amount of time under water immersion.

Fig. 4-32 bottom show the results when comparing the reloading stiffness obtained with the average of the indicated accompanying specimens, depending on the campaign, Fig. 4-32 left for the Campaign 1 (as per eq. 4.5) and Fig. 4-32 right for the Campaign 2 (as per eq. 4.6). The results show that the reloading stiffness obtained in campaign 1 are around $100 \%$ of the precracking stiffness of specimens stored with a crack in the humidity chamber. This means that the stiffness obtained healing in water is similar to the stiffness healing in humidity chamber, indicating a lack of mechanical recovery. If comparing the reloading stiffness with the precracking stiffness of accompanying uncracked specimens it can be interpreted that the obtained stiffness is around $20-30 \%$ of the stiffness of virgin specimens at the same age, which would be caused by the stiffness of the cracked section and the presence of the fiber reinforcement. 

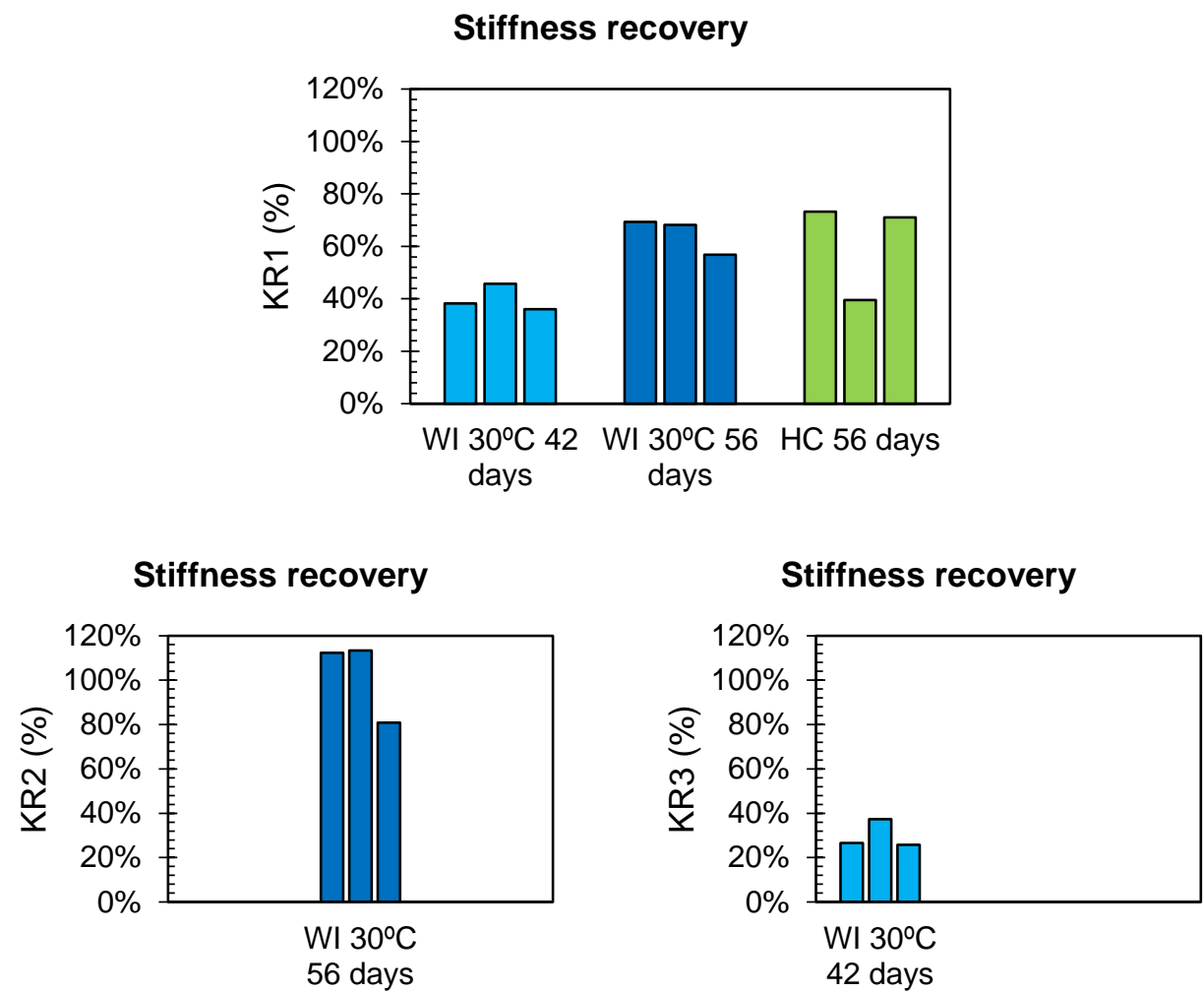

Fig. 4-32. Stiffness recovery by direct comparison with initial values, SRI (top), comparison with specimens at Humidity Chamber, SR2 (bottom left), and with accompanying uncracked specimens, SR3 (bottom right).

The other objective of the campaign is to compare the use of direct expressions as seen above with expressions with a reference parameter, as used in the literature (Table 4-12):

\begin{tabular}{lc}
\hline Concept & Formula of Stiffness Recovery \\
\hline Parameters of a same specimen & $K R 4 \%=\frac{K_{2}-K_{u}}{K_{1}-K_{u}} * 100$ \\
\hline $\begin{array}{l}\text { Accompanying specimens at HC } \\
\text { (Campaign 1) }\end{array}$ & $K R 5 \%=\frac{K_{2}-K_{2^{\prime} H C}}{K_{1}-K_{2^{\prime}} H C} 100$ \\
\hline $\begin{array}{l}\text { Accompanying specimens at } \\
\text { healing exposure (Campaign 2) }\end{array}$ & $K R 6 \%=\frac{K_{2}-K_{2^{\prime}}}{K_{1}-K_{2^{\prime}}} * 100$ \\
\hline
\end{tabular}


In this case, the results are inconsistent compared with those obtained with the direct expressions, in many cases obtaining negative values, or negative and positive for a same type of specimens and a large range of results, as displayed in Fig. 4-33. The unloading stiffness has been calculated using both, the tangent and secant versions. The graphs show the results obtained using the unloading tangent stiffness.

\section{Stiffness variation}

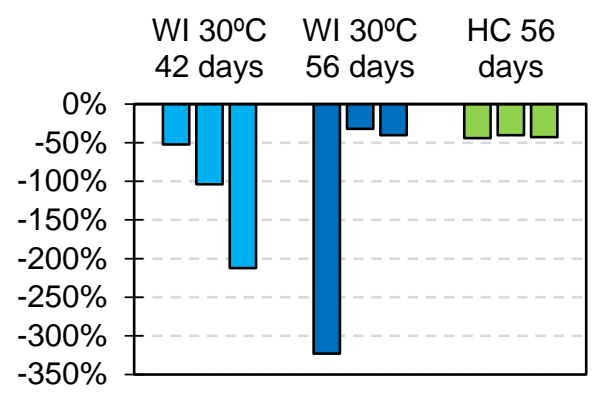

\section{Stiffness variation}

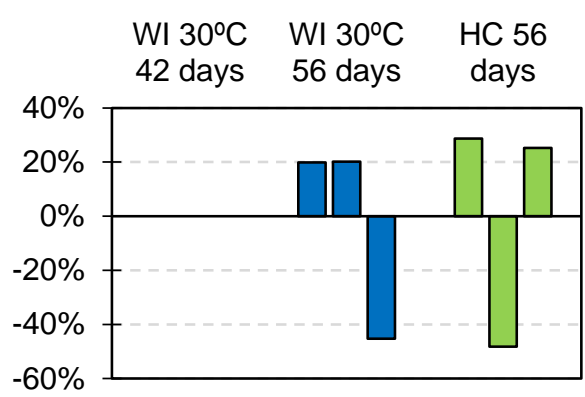

\section{Stiffness variation}

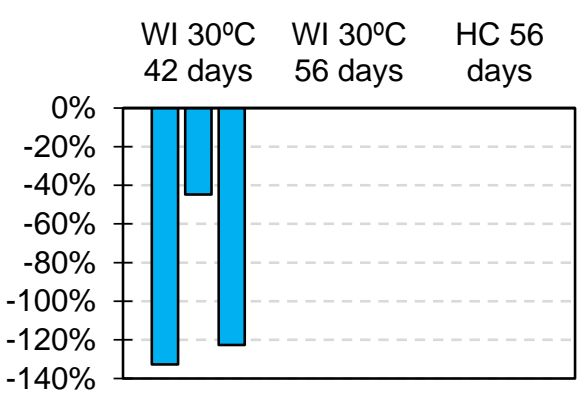

Fig. 4-33. Stiffness recovery by direct comparison with initial values, SR1 (top), and by comparison with specimens at Humidity Chamber, SR2 (bottom left), and with accompanying uncracked specimens, $S R 3$ (bottom right).

Fig. 4-34 displays the average and standard deviation values of the precracking stiffness for all specimens (same composition and same precracking age) together with the reload stiffness for the three groups healed in water immersion or stored in humidity chamber. There are very minor differences between the reloading slope of specimens healed in humidity chamber and that of water immersion for 56 days. However, specimens healed for 56 days had better response than those healed for 42 days, suggesting an evolution of the process. 


\section{Stiffness evaluation - Campaign 1}

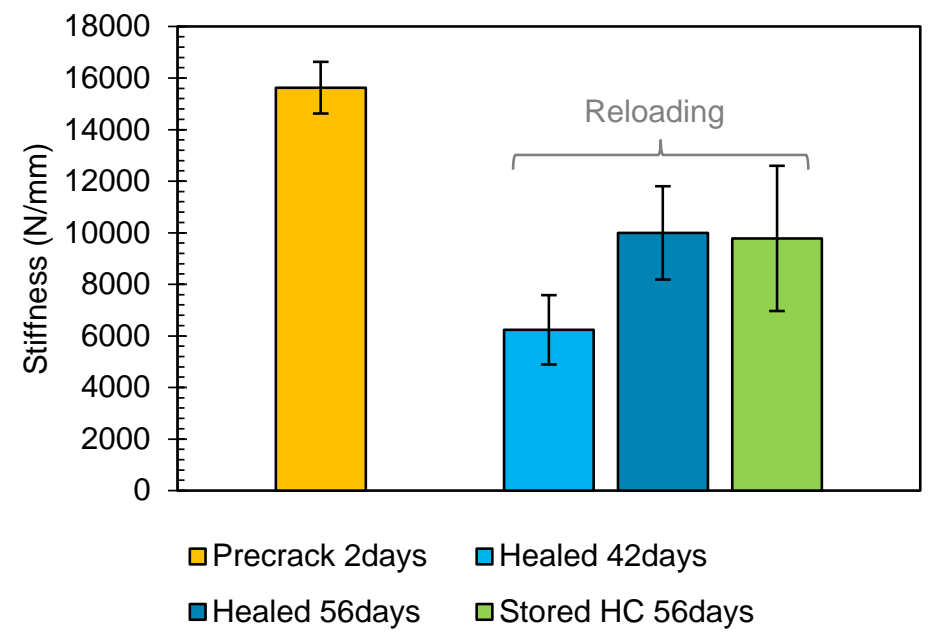

Fig. 4-34. Average and std. dev. values of stiffnes for the precracing and healed specimens.

Fig. 4-35 compares the values obtained for the stiffness of the precracking curve with the healed curve after 42 days and the precracking and reloading values for the reference specimens. In this case, reference specimens had higher reloading slope values than the rest of the groups, which might be caused by a much better matrix-fiber bond due to the maturing of concrete in uncracked state until the final test.

Stiffness evaluation - Campaign 2

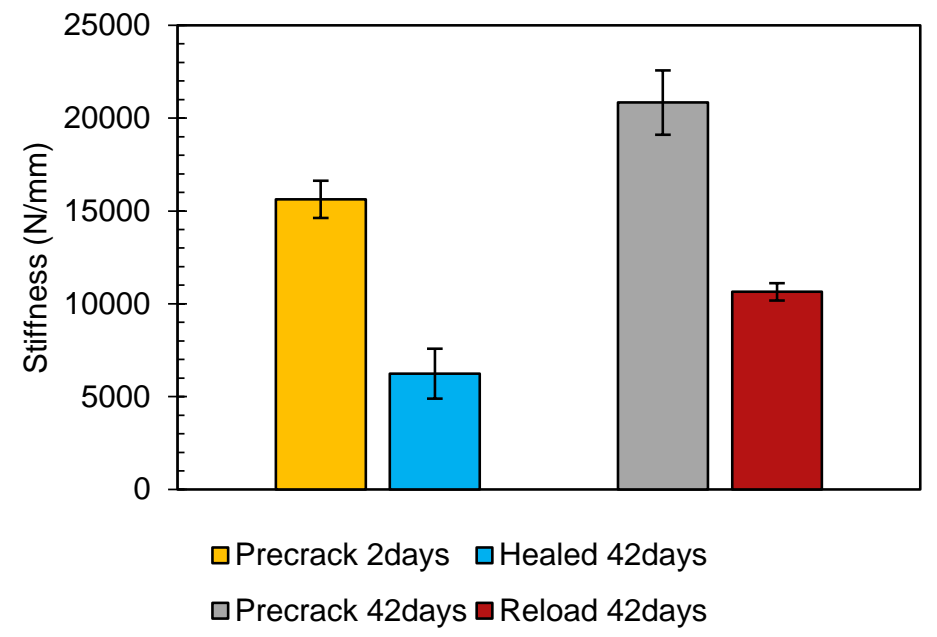

Fig. 4-35. Avg. and std. dev. values of stiffnes for the precracing, healed and reference specimens. 
Chapter 4. Validation of the methodologies for the evaluation of self-healing

Most of the results from the literature make a direct comparison of the stiffness with its previous value (Pelletier et al., 2011; Van Tittelboom et al., 2011; Snoeck \& De Belie, 2015), without taking into account the ageing and maturing effects that are produced in the material. These ageing phenomena will certainly affect mechanical properties, even including the bond between concrete matrix and the reinforcement, which will change the stiffness of the element. This effect will be of great importance when analyzing autogenous healing or autonomous healing designs with low mechanical recoveries, but will be of minor importance for autonomous healing designs with great mechanical recovery capacity Other studies use expressions that include a reference parameter in the equations (Van Tittelboom et al., 2012; Ferrara et al., 2014). In this work, these structures have showed higher dispersion, which makes the interpretation of the results more difficult.

\subsubsection{Effect of fiber content}

Additionally, this work also studied the effect of fiber content and concrete quality by using different compositions to verify if healing processes can be detected experimentally. Table 4-13 shows the concrete compositions, with and without the crystalline admixture for the two fiber contents compared.

In this campaign, three point bending test has been used for creating small-range damage of $0.15 \mathrm{~mm}$ crack after unloading, and the amount of CA type $\mathrm{C}$ was decided in $8 \%$ by the weight of cement letting specimens heal in water immersion at $30^{\circ} \mathrm{C}$, to maximize the strength recovery values. Again, the ages for precracking and start of healing process were fixed at 2 days. The healing time decided for this study have been 1.5 months (42 days).

\begin{tabular}{lcccc}
\hline & \multicolumn{2}{c}{ HQ FRC $\mathbf{4 0} \mathbf{~ k g} / \mathbf{m}^{\mathbf{3}}$} & \multicolumn{2}{c}{ HQ FRC $\mathbf{7 0 ~} \mathbf{~ k g} / \mathbf{m}^{\mathbf{3}}$} \\
\hline Material (kg/m $\mathbf{m}^{\mathbf{3}}$ ) & Control & CA Concrete & Control & CA Concrete \\
\hline Cement II/A-L 42.5 R & 275 & 275 & 350 & 350 \\
Water & 165 & 165 & 157.5 & 157.5 \\
Gravel (4-12 mm) & 908 & 922 & 946 & 965 \\
Natural sand & 988 & 947 & 894 & 842 \\
Steel fibers & 40 & 40 & 70 & 70 \\
Limestone powder & 50 & 28 & 50 & 22 \\
Crystalline Admixture & & 22 & & 28 \\
\hline Avg Slump (cm) & 12.50 & 13.50 & 11.00 & 12.00 \\
\hline Avg Compressive Strength (MPa) & 53.78 & 57.07 & 58.05 & 58.03 \\
\hline
\end{tabular}

Table 4-13. Composition of the four high quality concrete types used in this campaign.

Fig. 4-36 and Fig. 4-37 show the precracking and reloading curves obtained for control and CA specimens with the two fiber contents, respectively. No reloading curves show new load peaks, indicating the limit of the strength recovery achieved. The only symptom that could be indicating a self-healing process is a change in the slope of the reloading curve, seen in the inflexion points. This was experienced in one control specimen with $70 \mathrm{~kg} / \mathrm{m}^{3}$ of fibers and in all CA specimens with $40 \mathrm{~kg} / \mathrm{m}^{3}$ of fibers, but this aspect would need further verification. 
Control, HQ-FRC $40 \mathrm{~kg} / \mathrm{m}^{3}$

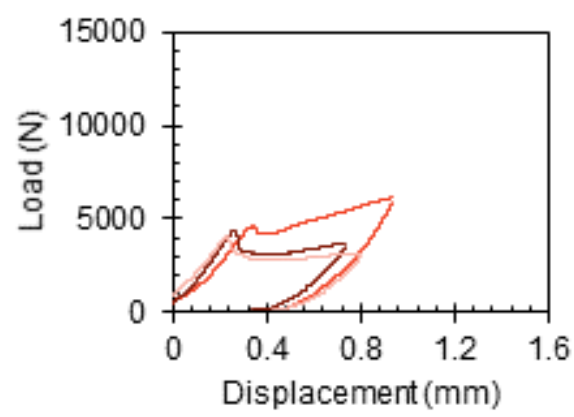

- Precracking 1 -Precracking 2

Precracking 3

Control, HQ-FRC $70 \mathrm{~kg} / \mathrm{m}^{3}$

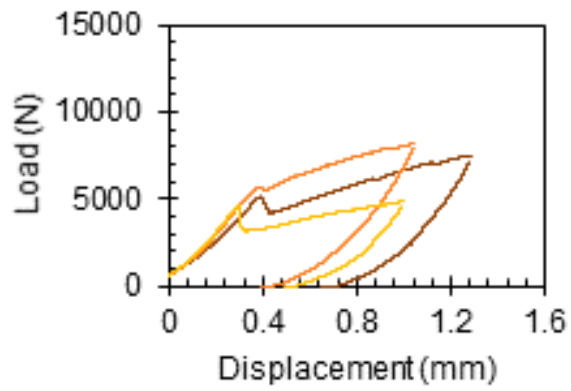

— Precracking 1 - Precracking 2

Precracking 3
Control, HQ-FRC $40 \mathrm{~kg} / \mathrm{m}^{3}$

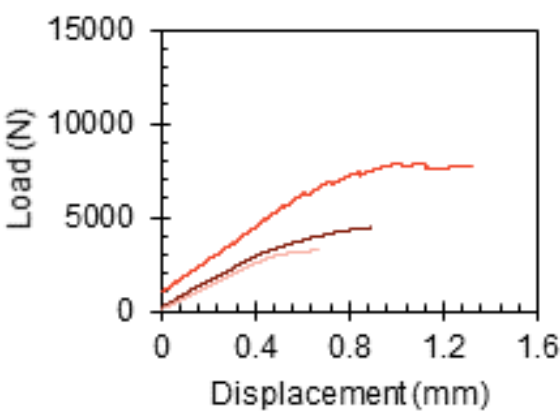

- Reloading 1 Reloading 2

Reloading 3

Control, HQ-FRC $70 \mathrm{~kg} / \mathrm{m}^{3}$

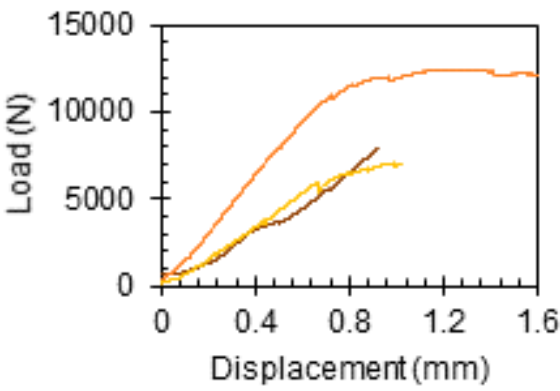

- Reloading 1 - Reloading 2 Reloading 3

Fig. 4-36. Precracking and reloading curves for the control high quality concrete. 
CA, HQ-FRC $40 \mathrm{~kg} / \mathrm{m}^{3}$

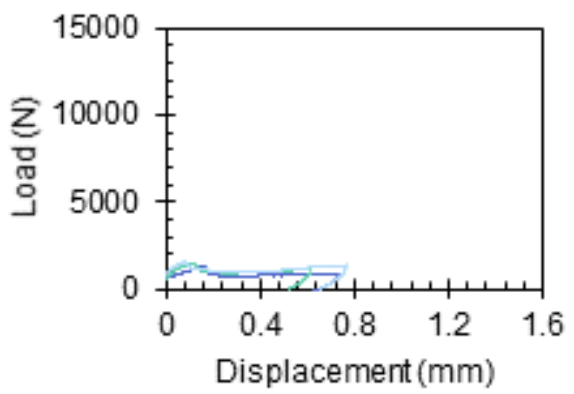

— Precracking 1 - Precracking 2

- Precracking 3

CA, HQ-FRC $70 \mathrm{~kg} / \mathrm{m}^{3}$

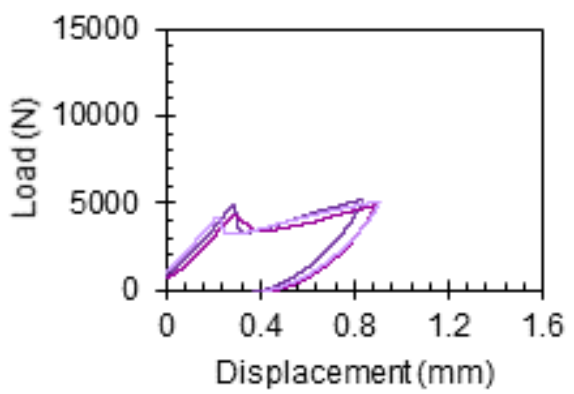

— Precracking 1 - Precracking 2

Precracking 3
CA, HQ-FRC $40 \mathrm{~kg} / \mathrm{m}^{3}$

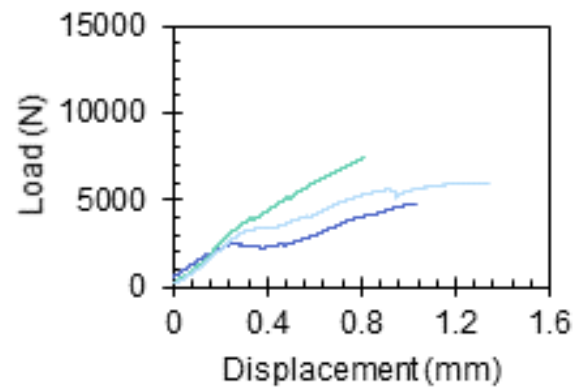

— Reloading 1 - Reloading 2

Reloading 3

CA, HQ-FRC, $70 \mathrm{~kg} / \mathrm{m}^{3}$

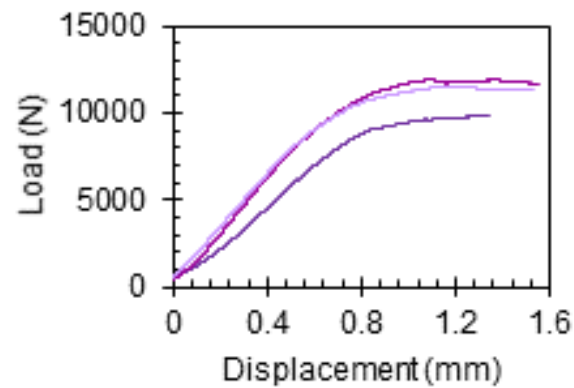

— Reloading 1 - Reloading 2

Reloading 3

Fig. 4-37. Precracking and reloading curves for the CA high quality concrete.

If evaluating the stiffness recovery compared with the precracking slope of accompanying specimens precracked at the final age after healing (Fig. 4-38), the results indicate that for each group the presence of CA slightly improved the stiffness recovery parameter, but also that increasing the content of fibers will increase the recovery parameters, as well. This should be considered, since the presence of higher amount of fibers in the cracked section will produce higher stiffness recovery but this could be misinterpreted as a self-healing effect. 


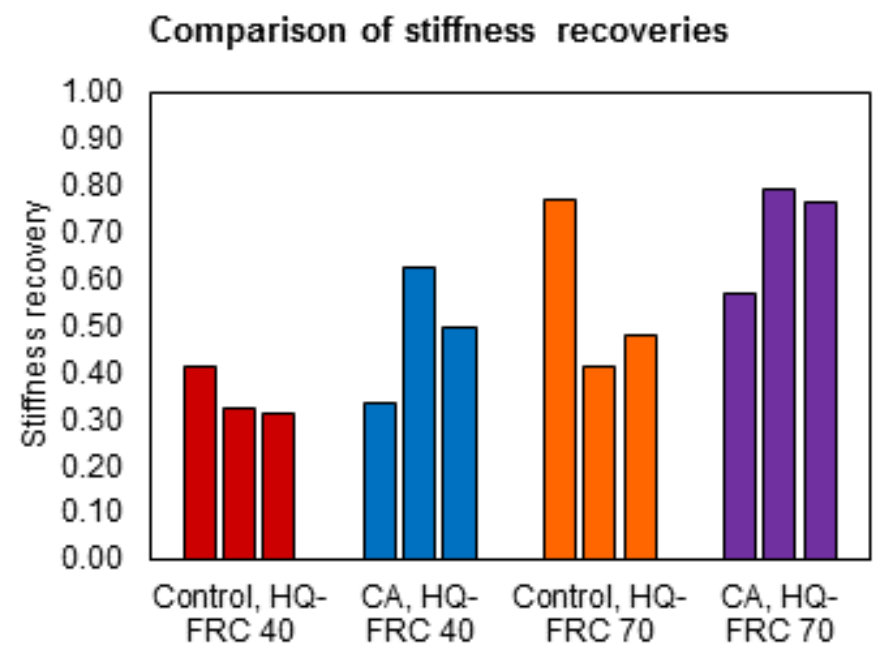

Fig. 4-38. Stiffness recovery depending on the fiber content and CA presence.

This subsection supports the conclusion of the effect of maturing obtained in the previous section 4.4.1, and the effect of bond in the measures when evaluating self-healing. These results indicate that direct comparison of groups with different amount of fibers or different reinforcement sizes will confuse the improvement of the bond of elements with higher amount of reinforcement with autogenous healing.

After these campaigns, it can be concluded that the precipitates produced in the specimens were not able to recover the strength of the matrix.

\subsubsection{Additional considerations}

Among all the experimental tests performed and not included in this work, two results worth to be highlighted. They were achieved when performing preliminary trials of three point bending tests in the mix with $60 \mathrm{~kg} / \mathrm{m}^{3}$ of fiber content.

Some of the tested samples achieved high stiffness values after the healing process, but this only occurred when the cracks were older ( 1 month) and not for early age cracks ( 2 days). This is displayed in Fig. 4-39. Moreover, a new crack path was achieved in one case, where the healed crack (visually filled) remained closed during the reloading stage (Fig. 4-40). This did not have a translation in a mechanical recovery, since precisely the specimen whose load-displacement curves are shown in Fig. 4-39, which was the one that achieved the clearest stiffness recovery, experienced a reopening of the old cracks. 


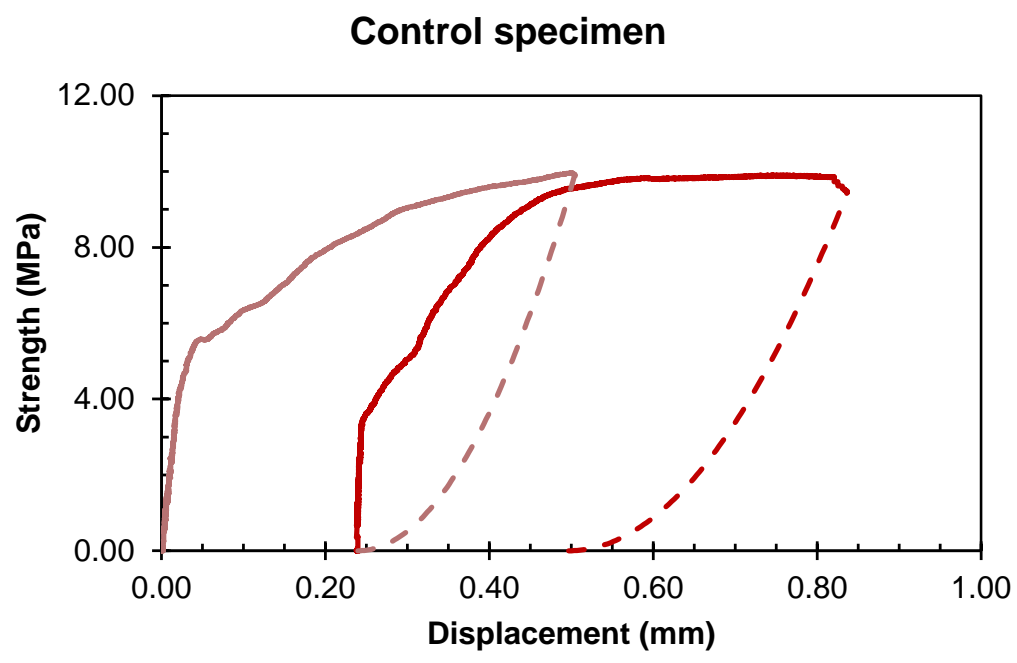

\section{_ Precracking _ Reloading}

Fig. 4-39. Example of healed specimen with stiffness recovery.
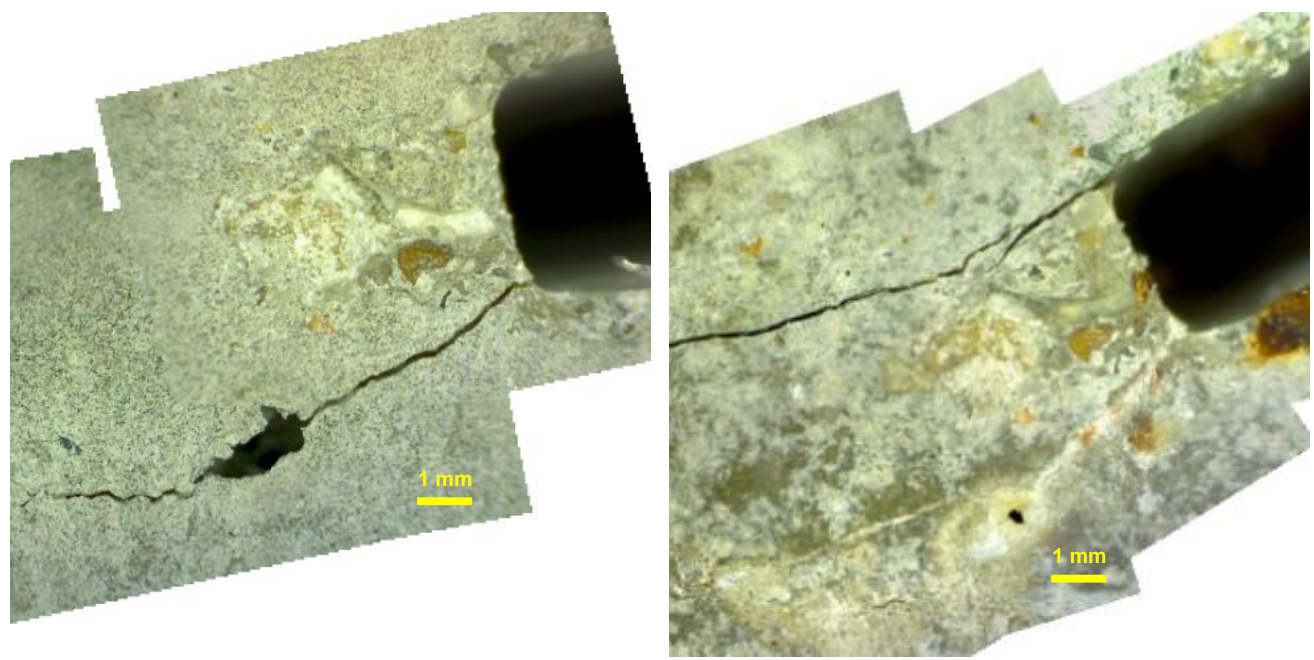

Fig. 4-40. New crack path produced at reloading after healing.

Again, these results highlight the redistribution of stresses produced when using high amounts of fibers, which, if not considered, can hinder the healing processes with the natural properties of fiber-reinforced concretes. 


\subsection{Sorptivity evaluation}

The experimental campaign for sorptivity was also used to evaluate crack closing evolution and effect of the crack orientation in Section 4.2 "Crack closing", in subsections 4.2.1 "Orientation of the crack during healing" and 4.2.2 "Precracking age effect in mortars". The efficiency of CA type A in terms of sorptivity were analyzed and discussed in Chapter 5, in Section 5.4 "Sorptivity", while in this chapter the stability of the results and the index for the evaluation are analyzed. This campaign focused on the evaluation of water sorptivity in mortars, using the composition of Table 4-14, and crack sizes around $0.3 \mathrm{~mm}$.

\begin{tabular}{ccc}
\hline (gr/liter) & Control & 4\% CA type A \\
\hline Cement & 450 & 450 \\
Water & 225 & 225 \\
Sand & 1350 & 1332 \\
CA & - & 18
\end{tabular}

Table 4-14. Mixture proportions for control and CA mortars.

Specimens were left to heal at the age of 7 days during 28 days in three healing conditions:

- $\mathrm{HC}$ (Humidity chamber): storage of the specimens inside a standard humidity chamber at $20^{\circ} \mathrm{C}$ and $95 \pm 5 \%$ relative humidity.

- WD (wet/dry cycles): immersion in tap water at a temperature of $15^{\circ} \mathrm{C}$ for 7 days and humidity chamber for another 7 days; this process is repeated four times.

- WI (water immersion at $15^{\circ} \mathrm{C}$ ): continuous immersion in tap water at $15^{\circ} \mathrm{C}$.

Two separate containers were used for CA and Control specimens, to avoid interactions between them. Water sorptivity was evaluated as explained in Chapter 3, for 4 hours and 16 minutes. Two precracking ages were planned first, 2 and 7 days. However, the effect of CA retarding setting time mortars was much noticeable, and specimens could not be precracked at the age of 2 days. Because of that, for that age, only control specimens were analysed.

\subsubsection{Initial sorptivity values, comparability of the different groups}

In all the groups, the average sorptivity value was lower for the accompanying uncracked specimens (Table 4-15) compared with the precracked specimens (Table 4-16). In grey, groups or specimens discarded, due to anomalous behavior.

\begin{tabular}{ccccccc}
\hline \multicolumn{7}{c}{ Sorptivity of uncracked specimens $\left(\mathbf{m m} \times \mathbf{m i n}^{-1 / 2}\right)$} \\
\hline Group & Age & Spec $\mathbf{1}$ & Spec $\mathbf{2}$ & Spec $\mathbf{3}$ & Average & STDV \\
\hline CTRL-WI & 7 days & 0,115 & 0,099 & 0,138 & 0,117 & 0,016 \\
\hline CTRL-HC & 7 days & 0,000 & 0,071 & 0,060 & 0,044 & 0,031 \\
\hline CTRL-WD & 7 days & 0,011 & 0,228 & 0,022 & 0,087 & 0,100 \\
\hline CA-WI & 7 days & 0,041 & 0,087 & 0,032 & 0,053 & 0,024 \\
\hline CA-HC & 7 days & 0,131 & 0,187 & 0,351 & 0,223 & 0,093 \\
\hline CA-WD & 7 days & 0,112 & 0,144 & 0,035 & 0,097 & 0,045 \\
\hline
\end{tabular}

Table 4-15. Initial sorptivity values of uncracked reference mortar specimens at the age of 7 days. 
Chapter 4. Validation of the methodologies for the evaluation of self-healing

In general, the dispersion of the cracked samples is very high, especially for the group of control specimens exposed at wet/dry cycles, showed high dispersion of initial damage, then their results should be tackled with caution, since they will not be directly comparable.

\begin{tabular}{cccccccccc}
\hline \multicolumn{7}{c}{ Sorptivity of precracked specimens $\left(\mathbf{m m} \times \mathbf{m i n}^{-\mathbf{1} \mathbf{2}}\right)$} \\
\hline Group & Age & Sp. 1 & Sp. 2 & Sp. 3 & Sp. 4 & Sp. 5 & Sp. 6 & Avg. & STDV \\
\hline CTRL-WI & 7 days & 0,567 & 0,498 & 0,526 & - & - & - & 0,530 & 0,028 \\
\hline CTRL-HC & 7 days & 0,182 & 0,464 & 0,281 & 0,167 & 0,086 & 0,099 & 0,213 & 0,129 \\
\hline CTRL-WD & 7 days & 0,487 & 0,154 & 0,694 & 0,057 & 0,046 & 0,079 & 0,253 & 0,248 \\
\hline CA-WI & 7 days & 0,260 & 0,235 & 0,147 & & - & - & 0,214 & 0,049 \\
\hline CA-HC & 7 days & 0,470 & 0,421 & 0,343 & 0,312 & 0,356 & - & 0,380 & 0,057 \\
\hline CA-WD & 7 days & 0,254 & 0,229 & 0,246 & 0,235 & 0,260 & 0,270 & 0,249 & 0,014 \\
\hline
\end{tabular}

If comparing the values of initial sorptivity for uncracked specimens at 2 days with the values obtained at 7 days, the results are comparable when uncracked (Table 4-17) age but considerably higher when precracked (Table 4-18). This could be produced by a higher hydration of the outer layers of mortar specimens, while interior did not achieve the same hydration degree.

\begin{tabular}{ccccccr}
\hline \multicolumn{7}{c}{ Sorptivity of uncracked specimens $\left(\mathbf{m m} \times \mathbf{m i n}^{\mathbf{- 1 / 2}}\right)$} \\
\hline Group & Age & Spec $\mathbf{1}$ & Spec $\mathbf{2}$ & Spec 3 & Average & STDV \\
\hline CTRL-WI & 2 days & 0,060 & 0,000 & 0,172 & 0,078 & 0,071 \\
\hline Table 4-17. Initial sorptivity values of uncracked reference & mortar specimens at the age of 2 days. \\
\hline
\end{tabular}

\begin{tabular}{cccccccccc}
\hline \multicolumn{10}{c}{ Sorptivity of precracked specimens $\left(\mathbf{m m} \times \mathbf{m i n}^{-1 / 2}\right)$} \\
\hline Group & Age & Sp. $\mathbf{1}$ & Sp. $\mathbf{2}$ & Sp. $\mathbf{3}$ & Sp. $\mathbf{4}$ & Sp. $\mathbf{5}$ & Sp. $\mathbf{6}$ & Avg. & STDV \\
\hline CTRL-WI & 2 days & 1,196 & 1,099 & 1,671 & 1,104 & 1,927 & 1,364 & 1,393 & 0,309 \\
\hline
\end{tabular}

Table 4-18. Initial sorptivity values of mortar specimens precracked at the age of 2 days.

To have robust results using this method, a larger number of specimens should be tested, to compensate the high dispersion. Despite this high dispersion, the results were analyzed to verify the procedure and the results, which should be considered as preliminary.

\subsubsection{Effect of healing conditions and preconditioning on sorptivity measurement}

The preconditioning before the final sorptivity test is an important point to cover, since water sorption will depend on the internal humidity inside the specimen, and being 28 days in in different conditions the internal humidity will be different. The option of using an oven to dry the specimens before the sorptivity tests was discarded to avoid the disintegration of the precipitates formed by the healing process, (by the evaporation of water particles and the handling) which is a consequence of the lack of knowledge of the byproducts formed by crystalline admixtures. 
To tackle this difficulty, it was decided to use uncracked reference specimens to isolate the sorption because of the existence of the crack from the matrix sorption, and also to keep the specimens out of their healing condition the day before sorptivity testing. These two measures will allow to avoid a lack of sorption due to saturation of mortar matrix, and to control the environmental variations of sorption.

Fig. 4-41 shows the average sorptivity obtained for uncracked and precracked specimens without CA (Control) and with CA. Precracked and healed specimens obtained similar values before and after healing (right column), while uncracked specimens show in all cases worse results after the healing and conditioning (left column). This means that comparatively specimens that suffered a precracking and healing have an additional process to matrix impermeabilization that is helping to reduce water sorption.

Uncracked

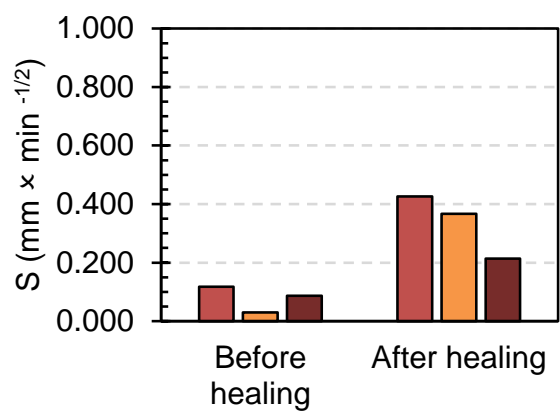

口CTRL WI $\quad$ CCTRL HC $\quad$ aCTRL WD

Uncracked

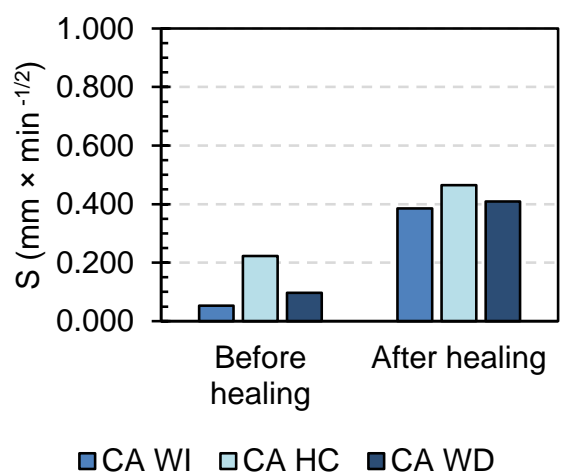

Precracked

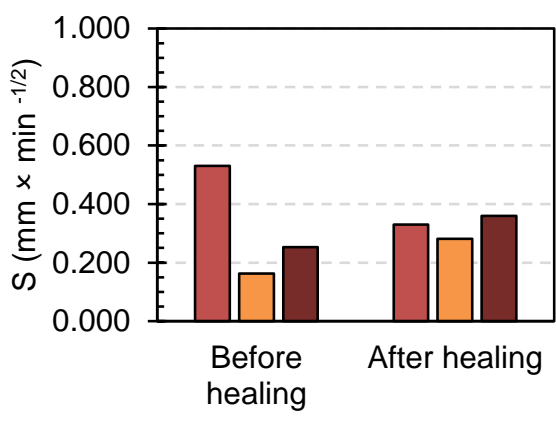

口CTRL WI $\quad$ CCTRL HC $\quad$ CCTRL WD

\section{Precracked}

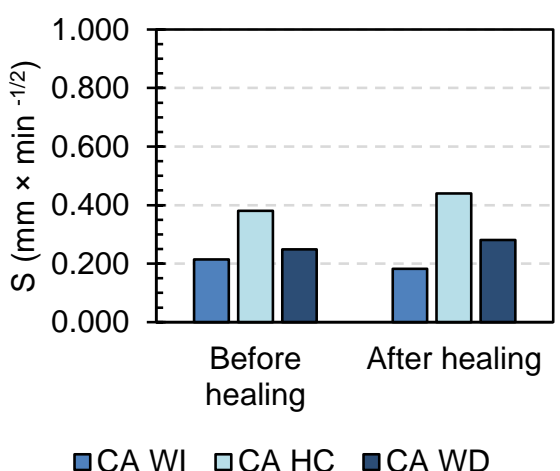

Fig. 4-41. Results of sorptivity for control (upper row) and CA (bottom row) specimens.

Even though specimens were let out their conditioning exposure the day before sorptivity test, their previous state was different, and this preconditioning might have not been enough 
Chapter 4. Validation of the methodologies for the evaluation of self-healing

to have the same situation. Because of that reference specimens and crack sorptivity as an evaluating parameter have been used to avoid this effect.

Comparing Fig. 4-41 and Fig. 4-42 it can be seen that the average values of S of the crack gives clearer results than analysing $\mathrm{S}$ directly. For instance, values before healing are similar for control and CA specimens, being all of them around $0.15 \mathrm{~mm} \times \min ^{-1 / 2}$ and CTRL-WI group with slightly higher values and CTRL-HC with slightly lower values. This means that all specimens had similar initial damage according to the sorptivity values. Looking at the results after healing, CA specimens healed in humidity chamber achieved values of zero crack sorptivity, that means no healing of the crack. Control specimens, however, got slight improvement after healing. This could be produced by the small differences in the initial damage.
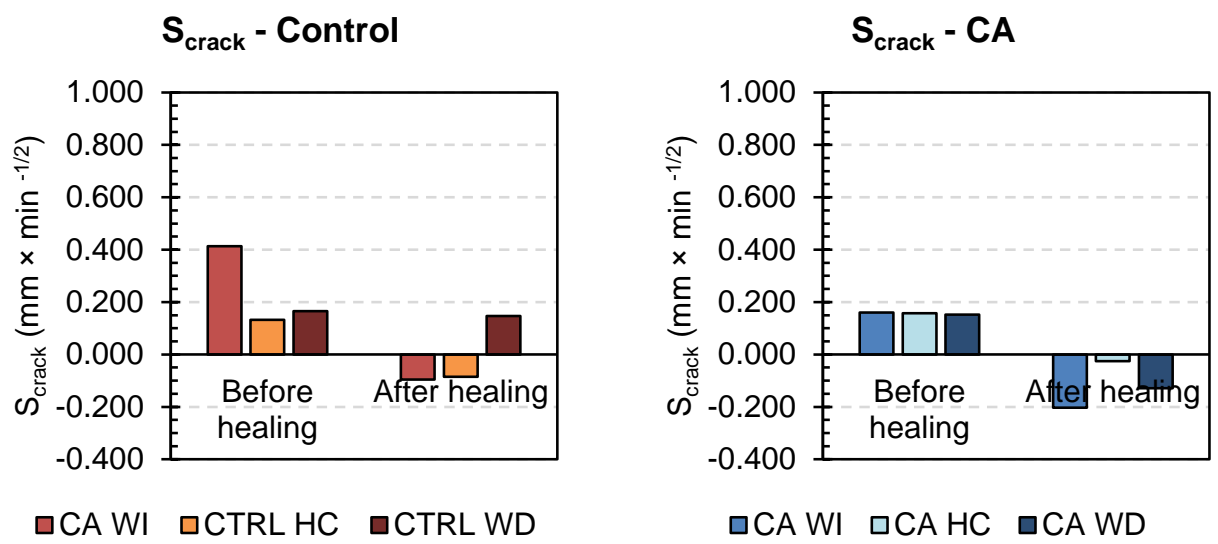

Fig. 4-42. Average results of crack sorptivity for control (left) and CA (right) specimens.

Since the sorption of water produced through the area of the notch has been removed, this means that the area of the crack exposed absorbs less water after healing than before healing, presumably due to a densification of that area. This densification is different for each group, which will be further discussed in Chapter 5 "Efficiency of autogenous healing and autonomous healing with crystalline admixtures".

Fig. 4-43 shows crack sorptivity results of control specimens precracked at the age of 2 days and at the age of 7 days after healing under water immersion. The results show that the initial crack sorptivity obtained for specimens precracked at 2 days is much higher than for specimens precracked at 7 days, this is probably produced by the higher permeability of concrete at 2 days compared with its permeability at 7 days. There is a reduction of the crack sorptivity after healing compared with before healing in both cases, with higher decrease in younger cracks $\left(0.903 \mathrm{~mm} \times \mathrm{min}^{-1 / 2}\right.$ compared to $\left.0.443 \mathrm{~mm} \times \mathrm{min}^{-1 / 2}\right)$. 


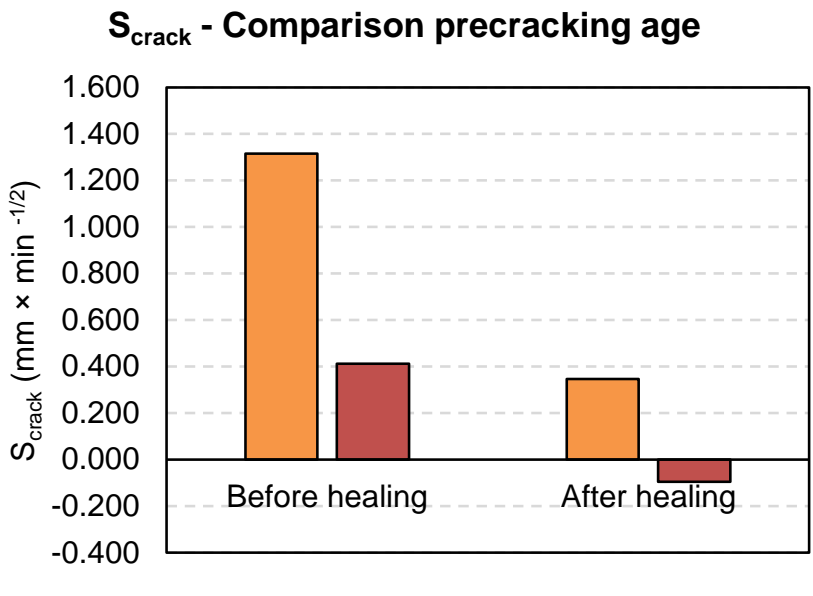

口CTRL WI 2d $\quad$ aCTRL WI 7d

Fig. 4-43. Average results of crack sorptivity for control specimens precracked at 2 and 7 days.

This study shows high dispersion of the sorptivity results with high sensitivity to the features of the crack formed in the precracking process, being a weak point of the method for the evaluation of self-healing. The use of crack sorptivity as the parameter for evaluating self-healing improved the evaluation.

\subsection{Summary of conclusions about the methods for the self- healing evaluation}

Several conclusions can be drawn from the work included in this chapter regarding the validation of the experimental methods for the evaluation of self-healing in concrete.

\section{Regarding crack closing evaluation:}

Four geometrical parameters have been used and analyzed in this work: $w_{\max }$, maximum crack width, $w_{\text {avg }}$, average crack width, $A_{e s t}$, estimated crack area and, $A_{p x}$, area measuring black pixels. The first one is the method with the shortest post-processing time and the last one is the method with the longest post-processing time. The experimental work carried out has demonstrated that crack closing is an effective and simple parameter to evaluate selfhealing, and the measure of the average crack width by using several equidistant points in the length of the crack $\left(w_{\text {avg }}\right)$, is a cost-effective method to evaluate the damage extent.

Moreover, the orientation of the crack during the healing process has been detected as a parameter of great importance, and not considering this aspect may lead to misleading conclusions.

\section{Regarding water permeability evaluation:}

The water permeability method proposed in this work uses high pressured water ( 2 bars) and has good stability and repeatability, which is an excellent property of the method. It 
only showed slight decreases of the water flow, which could be produced by the entrance of dust or contaminants or by the hydration processes of the cement matrix in the crack. A bad lateral sealing can produce a weak point for performing the test, but once a good sealing procedure is stablished, the proposed method is easy to implement in concrete laboratories.

The use of multiple water permeability tests in a same specimen slightly reduced the measures of water flow obtained, and thus, if the expected values will have small range of results, it will be convenient to avoid the use of multiple tests in a same specimen to avoid adding an interference. Most of the studies reported in the literature have not analyzed this effect and use frequently intermediate tests, even for analyzing autogenous healing with mixes of similar compositions. For campaigns with the objective of comparing groups with expected similar response this effect can be of noticeable importance, even if specimens are precracked at later age.

\section{Relation between crack closing and water permeability:}

The relations obtained between crack parameters and water permeability show that they follow a cubic relation, as reported in (Edvardsen, 1999), but with certain dispersion, which are assumed to be produced by the in-depth geometry of the cracks and the presence of fibers. This dispersion is even higher for the relation of the parameters after the healing process, which also emphasizes the random nature of the healing process.

The relation found between water flow and crack width indicates that the evaluation of water flow could be considered as an indirect way to evaluate the crack volume before healing takes place, since the tortuosity of the crack in the interior of the crack will condition the ability of water to pass through the specimen.

Using water permeability as a reference, the crack closing parameters that showed the better adjustment were the area of the crack and the crack width average, as measured in five points of the crack length. Since the use of crack width average is easier in terms of time of measuring and post-processing of the images, this is the recommended method for the crack closing evaluation.

The results obtained using Crack and Healing Ratios showed some dispersion for small damages, which could depend on the precision of the method, and then should not be blindly trusted for specimens with the smallest damage.

Autogenous and crystalline-admixtures-based healing types have been detected as phenomenon has been detected as a phenomenon with a high surface component, with some effects also in the inside part of the crack, as detected with the internal water permeability tests, but without visual presence of precipitates in the interior of the crack.

\section{Regarding mechanical regain evaluation:}

Regarding the evaluation of the mechanical recoveries, most of the results from the literature do not consider ageing and maturing that are produced in the material. The results obtained show that maturing of concrete is a parameter of noticeable importance and therefore should be considered in the studies. This consideration is completely necessary for the evaluation of early age cracks, but it is also recommended in older cracks, since it affects peak load, stiffness and residual strength. 
Other effects such as the bond between concrete matrix and the reinforcement and its evolution with the concrete maturing will change the stiffness of the element, and again, this could hinder the small healing effects within the natural change of properties that is produced in normal concrete. This will affect especially those fiber-reinforced concretes with high amounts of fibers, such as SHCC and ECC as reported in the literature review.

This is an important point to consider for all those methods which are based on improving autogenous healing and or of uncertain capability. These effects will not be a problem when using self-healing products with considerable self-healing capacity, such as the repair materials placed inside tubes in fixed locations.

Regarding the use of different expressions for the evaluation of the mechanical regain, this study shows that direct expressions have more stable results and being easier to interpret, and then, this option is the recommended. The use of appropriated references has also been discussed, depending on the objective of the study.

This chapter has highlighted the high sensitivity of the parameters to the slight variations of the mechanical behavior of concrete and its ageing and maturing processes. Then, comparing specimens with different amount of fibers or changing the amount of reinforcement, such as increasing the diameter of a rebar, can induce differences because of the variation of the bond and adherence strength with the age. This point has not been further evaluated in this work, but it is important to notice that this effect can present a synergy in UHPFRC, ECC or SHC types of concrete, due to both, their much higher binder content compared with usual types of concrete or fiber-reinforced concrete, and their high continuing hydration and pozzolanic reactions in the matrix. This could lead to misleading results in terms of the self-healing quantification.

\section{Regarding sorptivity evaluation:}

Moreover, the sorptivity analysis is a test easy to implement but this study shows high dispersion of results due to the variation of the cracks. The use of the parameter of crack sorptivity permits to use accompanying specimens without drying the healed specimens in the oven, and then permits to evaluate densification and healing processes around the crack. However, this study shows highly dispersed results with high sensitivity to the features of the crack formed in the precracking process.

\section{Boundary conditions for Chapter 5:}

In this section the proposed water permeability test has been analyzed in specimens stored in humidity chamber, which was classified as a reference exposure without healing.

Regarding the healing time needed for the experimental campaign, both continuous water immersion and wet/dry cycles regimes can achieve considerably good crack closing results, and water permeability reductions by autogenous healing, which was consistent with the results presented in the literature review.

Precracking ages of 2 and healing times of 28 or 42 days allow to see effects in the crack closing and water permeability of cracks up to $0.35-0.40 \mathrm{~mm}$. Early-age cracks with initial water flows up to around $3000 \mathrm{ml} / 5 \mathrm{~min}$ or crack widths of around $0.20 \mathrm{~mm}$ are likely to have complete healing in terms of both, crack closure and water permeability. In fact, most 
Chapter 4. Validation of the methodologies for the evaluation of self-healing

of the reaction happened in the first 14 days of healing for early age cracks. Older cracks showed significant but reduced healing capabilities. 



\section{Chapter 5. Efficiency of autogenous healing and autonomous healing with crystalline admixtures}


Self-healing concrete: efficiency evaluation and enhancement with crystalline admixtures 


\subsection{Introduction}

This chapter displays the results concerning the efficiency of autogenous healing and the improvements achieved when using crystalline admixtures, in concrete and mortars by using the methods defined in previous chapters.

This chapter is divided in the introduction and four sections. Section 5.2 explains a broad study for a fixed concrete composition, crystalline admixture dosage and healing time, analyzing in detail the effects of initial damage (initial crack width or initial water flow depending on the parameter analyzed), effect of water/cement ratio, effect of the presence of CA and the effect of the healing exposure. Finally, it includes a comparison between the efficiencies obtained in terms of crack closing and water permeability. Section 5.3 shows the results obtained using crystalline admixtures regarding the mechanical recoveries, and Section 5.4 regarding the sorptivity analysis. At last, Section 5.5 analyzes the effects of CA as a concrete admixture, comparing the composition of $\mathrm{CA}$ and the healing precipitates produced in the crack, the effects in strength and workability in mortar and concrete scales, and its effect in hydration of mortars by isothermal calorimetry analysis.

\subsection{Influence of several parameters on self-healing by means of crack closing and water permeability}

This experimental campaign is a thorough study that aims to analyze the effect of a crystalline admixture (Type A) comparing with autogenous healing on two types of concrete by means of crack closing and water permeability. This campaign uses two concrete types, of two different strength levels, whose composition is shown in Table 5-1. The mixtures with w/c ratio of 0.45 and with cement content of $350 \mathrm{~kg} / \mathrm{m}^{3}$, correspond to a concrete with strength class of $\mathrm{C} 45 / 55$, and the one with w/c of 0.60 has the concrete class of $\mathrm{C} 30 / 37$. CA was added in substitution of the fine material (limestone) to isolate the effect of the admixture from the fine effect. Superplasticizer, ViscoCrete 5720, dosage was adjusted in each different group in order to get similar slump (140 $\mathrm{mm} \pm 20 \mathrm{~mm})$.

\begin{tabular}{lcccc}
\hline & \multicolumn{2}{c}{ w/c=0.45 } & \multicolumn{2}{c}{ w/c=0.60 } \\
\hline Material $\left(\mathbf{k g} / \mathbf{m}^{\mathbf{3}}\right.$ ) & Control & CA Concrete & Control & CA Concrete \\
\hline Cement II/A-L 42.5 R & 350 & 350 & 275 & 275 \\
Water & 157.5 & 157.5 & 165 & 165 \\
Gravel (4-12 mm) & 950 & 959 & 908 & 915 \\
Natural sand & 899 & 875 & 987 & 967 \\
Steel fibers & 40 & 40 & 40 & 40 \\
Limestone powder & 50 & 36 & 50 & 39 \\
Crystalline Admixture & - & 14 & - & 11 \\
\hline Avg Slump (cm) & 13 & 16 & 15 & 14 \\
\hline Avg Compressive Strength (MPa) & 55 & 61 & 38 & 41 \\
\hline
\end{tabular}

Table 5-1. Composition of the four concrete types used in this campaign. 
Specimens were precracked by splitting test at the age of 2 days to achieve cracks up to 0.4 $\mathrm{mm}$ crack widths, and were stored in the healing exposure at the age of 3 days. Only initial and final water permeability and crack closure were carried out to avoid adding uncertainties and uncontrolled influences. In total, 203 concrete specimens were analyzed (Fig. 5-1).

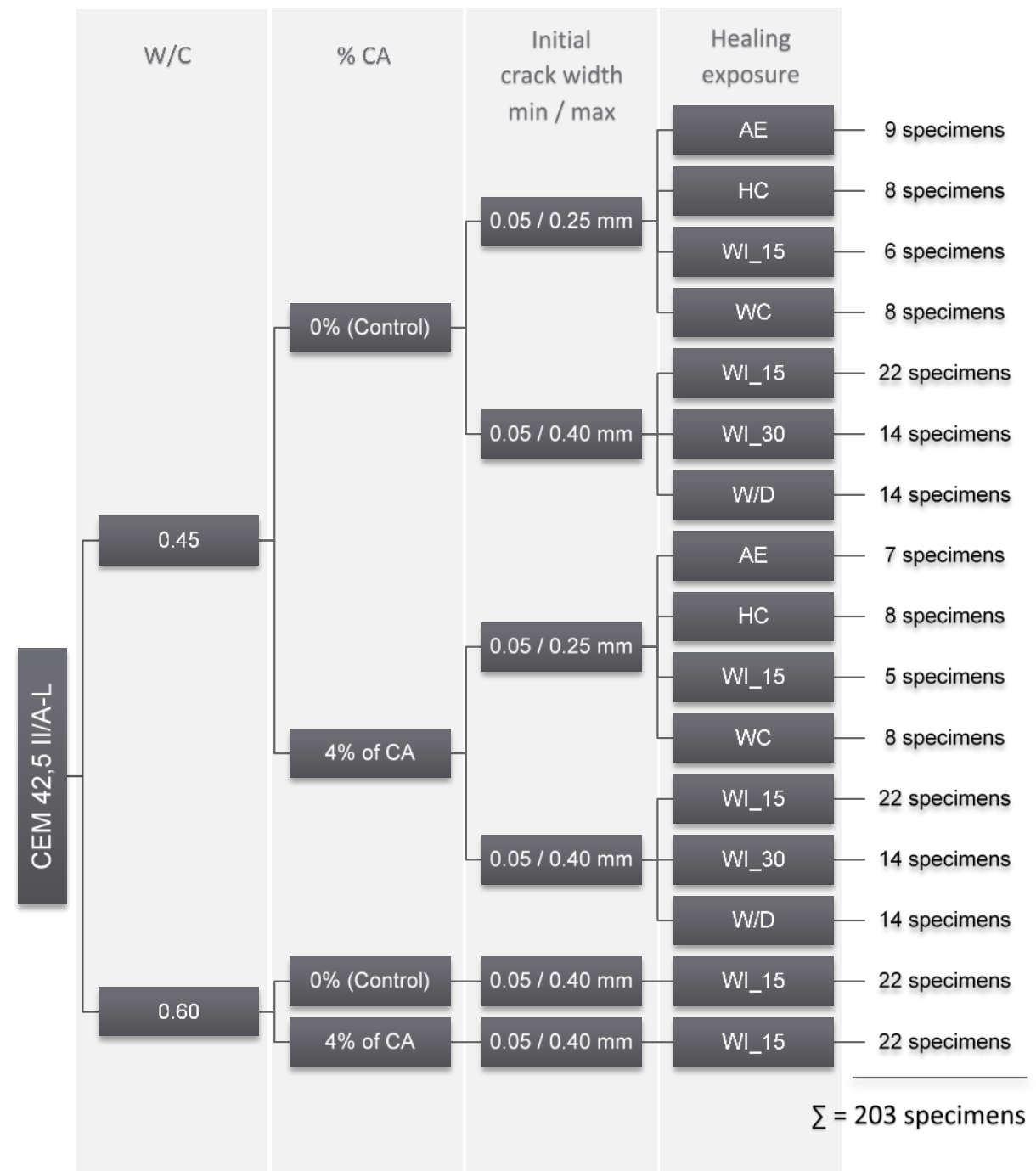

Fig. 5-1. Diagram showing the number of specimens analyzed per group.

The six healing conditions analyzed are (described in detail in Subsection 3.1.5):

- AE (Air Exposure): laboratory conditions inside a room without exterior influences, $17 \pm 1^{\circ} \mathrm{C}$ and $40 \pm 5 \%$ of relative humidity. 
- HC (Humidity chamber): storage of the specimens inside a standard humidity chamber at $20^{\circ} \mathrm{C}$ and $95 \pm 5 \%$ relative humidity.

- WC (water contact): A layer of water of $2 \mathrm{~cm}$-water on the top crack, and storage in humidity chamber at $20^{\circ} \mathrm{C}$ and $95 \pm 5 \%$ relative humidity (see Fig. 3-2).

- WD (wet/dry cycles): immersion in tap water at a temperature of $15^{\circ} \mathrm{C}$ for 3.5 days and air exposure for another 3.5 days (air conditions: $17 \pm 1^{\circ} \mathrm{C}$ and $40 \pm 5 \% \mathrm{RH}$ ).

- WI_15 (water immersion at $15^{\circ} \mathrm{C}$ ): continuous immersion in tap water at $15^{\circ} \mathrm{C}$.

- WI_30 (water immersion at $30^{\circ} \mathrm{C}$ ): continuous immersion in tap water at $30^{\circ} \mathrm{C}$.

This section is arranged in three subsections "Effect of the healing exposure", "Effect of water/cement ratio and cement content", and "Comparison between parameters". In the two first sections, the effect of the extent of the damage and the effect of adding crystalline admixtures, will be analyzed. These analyses will be performed by using crack closing and water permeability healing parameters defined in the previous chapters. In the third section, the results obtained by the two tests will be compared, among them. During the whole section, the results will be compared with those reported in the literature.

The criteria that will be maintained during this whole chapter is:

- Healing results in terms of water permeability will be displayed showing the Healing Ratio in the vertical axis and the initial water flow in the horizontal axis. Higher initial water flows indicate higher initial damage levels.

- Healing results in terms of crack closing will be displayed showing the Closing Ratio in the vertical axis and the average initial crack width in the horizontal axis. Higher initial crack widths indicate higher initial damage levels.

- The color and symbol codes followed in this whole chapter is:

- Red and warm colors in circular markers for the control group without crystalline admixtures, that is, those specimens that will heal only by autogenous healing.

$\Delta$ Blue and cold colors in triangular markers for the group with crystalline admixtures.

The structure for displaying the results is shown in Fig. 5-2

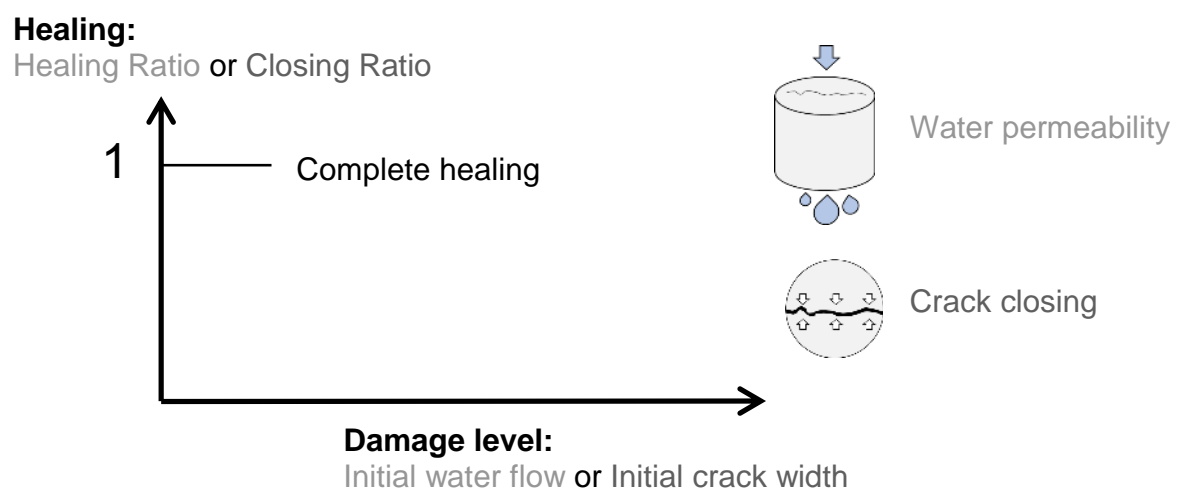

Fig. 5-2. Structure for displaying the results of water permeability and crack closing. 


\subsubsection{Effect of the healing exposure}

The healing properties of all specimens with w/c ratio of 0.45 have been analyzed under six different exposures, but two of them (water contact and air exposure) only were analyzed in the small range cracks (up to $0.25 \mathrm{~mm}$ ).

The healing results, by means of permeability tests are shown in Fig. 5-3, where it is displayed that specimens in direct contact with water obtained higher Healing Ratios than those in different moist conditions. Wet/dry cycles obtained Healing Ratios below 0.50 for CA specimens and around 0.50 for control group.

Closing Ratio maintained the same trend but in general with higher values (Fig. 5-4). This means that an evaluation of visual closure can overestimate the healing capability in comparison to the recovery of durability properties. Because of that, an evaluation of selfhealing only by visual observation could lead to misconceptions of the real recovery of properties. Using the Closing Ratio, it was also concluded that WI at 15 and $30^{\circ} \mathrm{C}$ were the exposures with the best results, and that self-healing was directly correlated with the amount of water available for the reaction. The biggest differences were achieved for specimens in the exposures of WC and WD cycles.

Fig. 5-5 analyzes the response of specimens in exposures without direct contact with water ( $\mathrm{HC}$ and $\mathrm{AE}$ ) and precracked to low levels of damage (up to $0.25 \mathrm{~mm}$ ). This graph demonstrates the absence of autogenous and CA-based healing in those exposures, which means that the phenomena will not be reliable for these environmental conditions.

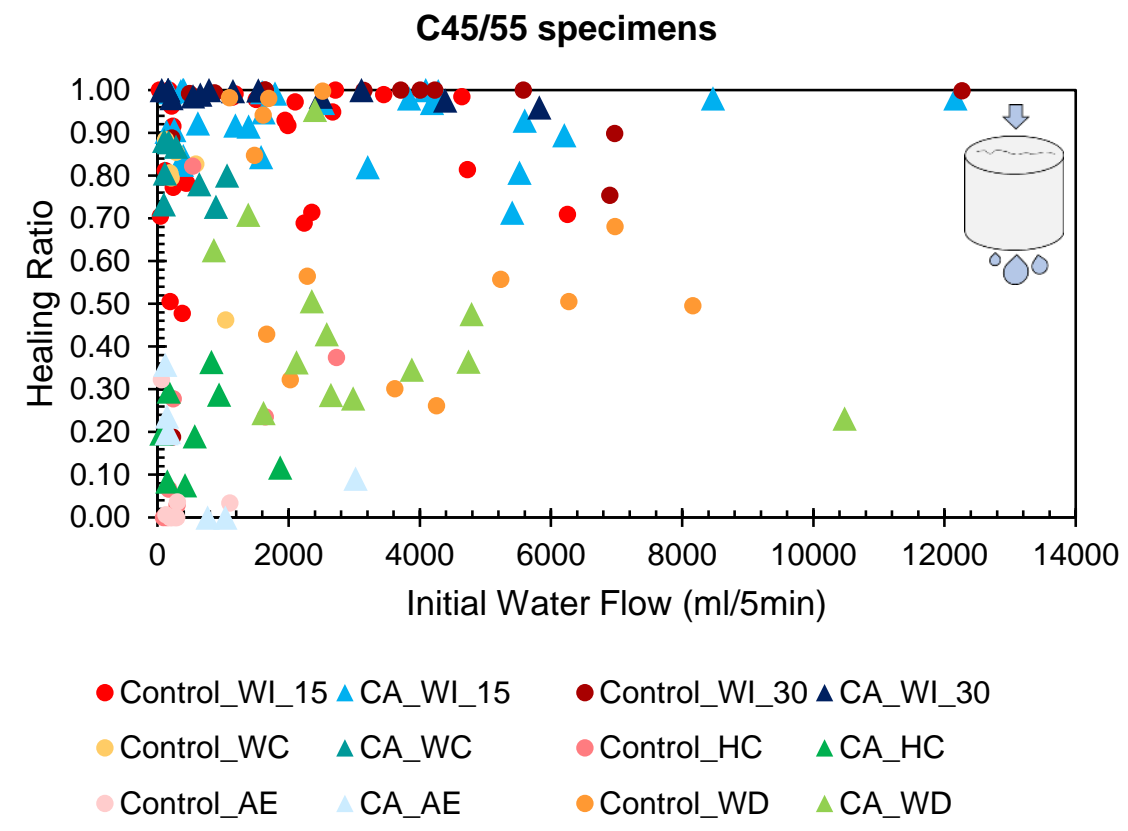

Fig. 5-3. Healing Ratio vs. initial water flow of specimens with $w / c$ of 0.45 for all the exposures. 


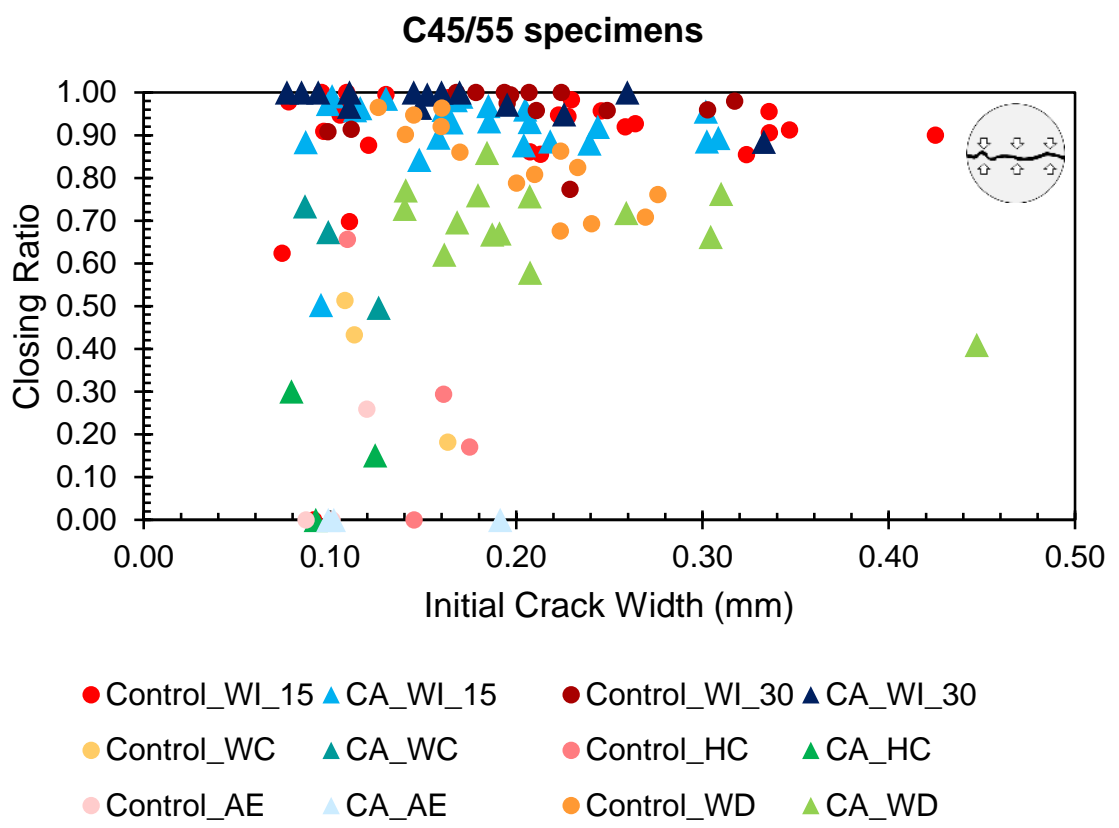

Fig. 5-4. Closing Ratio vs. initial crack width of specimens with $w / c$ of 0.45 for all the exposures.

\section{C45/55 specimens}

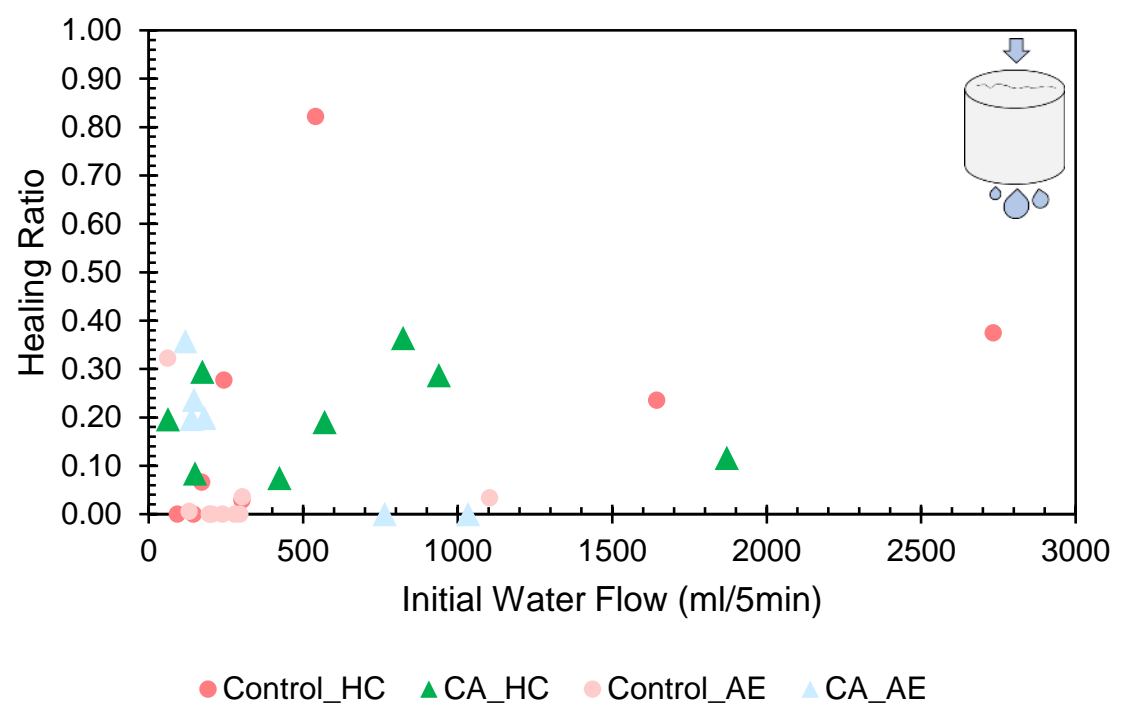

Fig. 5-5. Detail of Fig. 5-3, Healing Ratio vs. initial water flow of control and CA specimens in exposures without direct contact with water, with $w / c$ of 0.45 and small cracks. 
Fig. 5-6 and Fig. 5-7 show the effect of the healing exposure for control and specimens with CA respectively. Only two specimens from the CA group obtained negative Healing Ratios, and both for the low humidity exposure (AE). Negative Healing Ratio were more frequent in control specimens, taking place for $\mathrm{AE}$ and for the Humidity Chamber exposure as well.

For both analyzed groups, higher Healing Ratios were achieved when specimens were stored under water immersion. Wet/dry cycles and water contact of $2 \mathrm{~cm}$ of water layer showed similar behaviors for control specimens. In contrast, for the CA group, the WC exposure achieved better results and less dispersion than WD conditions. In general, specimens with CA got less dispersion for all exposures, which indicates a more reliable and predictable behavior of concrete with this admixture. Specimens with initial water flows under $6000 \mathrm{ml} / 5 \mathrm{~min}$ were able to heal almost completely under water immersion for both autogenous and CA-based healing. Control specimens showed high dispersion while specimens with CA were gathered in clear groups depending on the exposure. CA group under the $\mathrm{AE}$ and $\mathrm{WD}$ exposure had higher dispersion than the rest of exposures for that mixture.

For CA groups, increasing the water content clearly increased the Healing Ratio. For control specimens there was a high dispersion zone for cracks smaller than $0.10 \mathrm{~mm}$, and several specimens achieved almost complete healing (Healing Ratio around 1.0). For CA specimens' results were disperse only in the case of WD exposure. In this case, most of the specimens achieved Healing Ratios higher than 0.80 . 


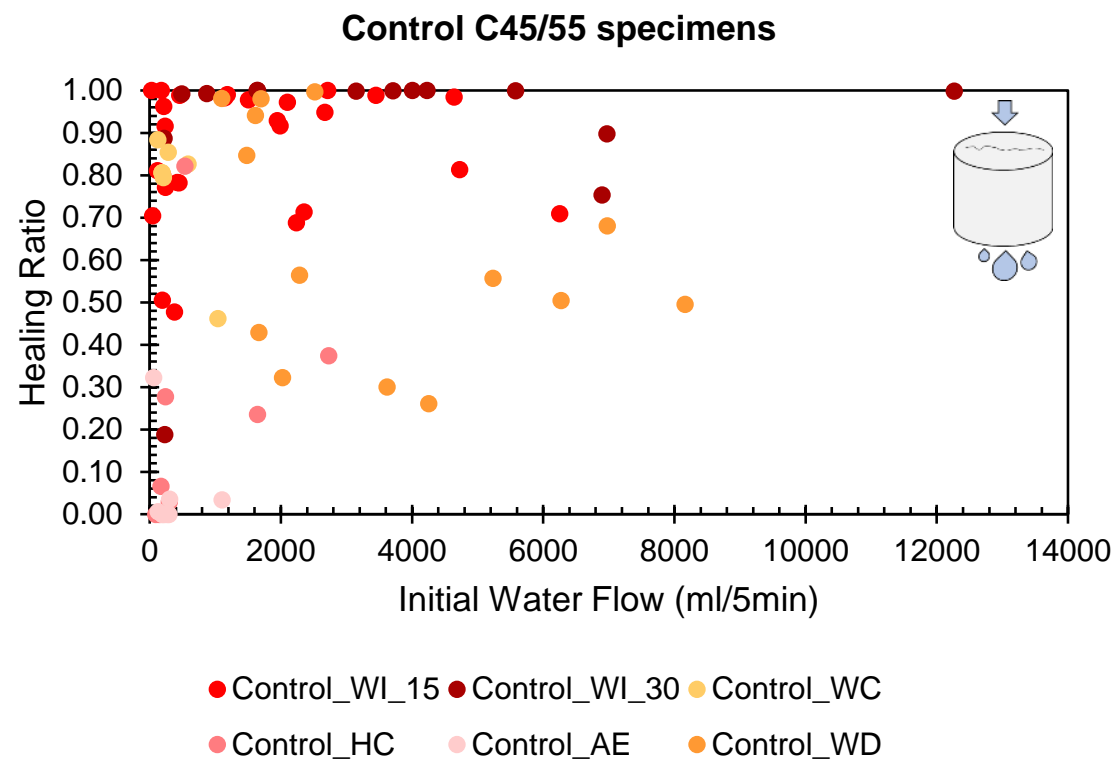

Fig. 5-6. Detail of Fig. 5-3, Healing Ratio vs. initial water flow of control spec. with w/c of 0.45.

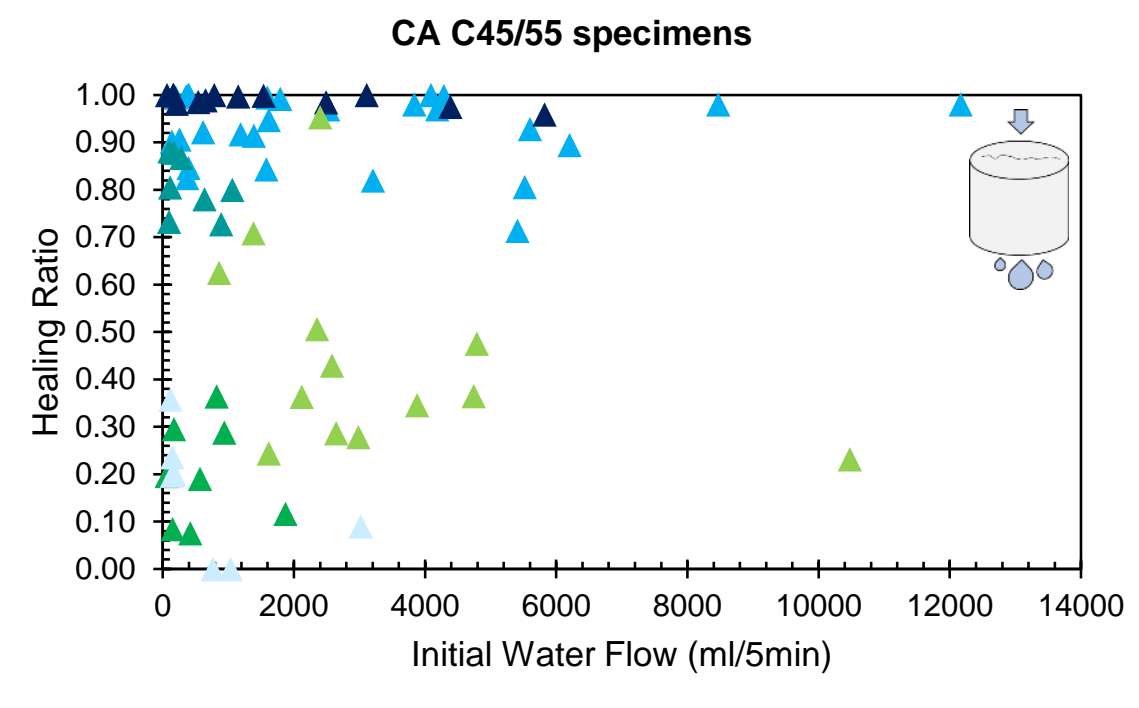

$\triangle \mathrm{CA}$-WI_15 $\triangle \mathrm{CA}$-WI_30 $\triangle \mathrm{CA} \_W C \triangle \mathrm{CA} \_\mathrm{HC} \triangle \mathrm{CA} \_\mathrm{AE} \triangle \mathrm{CA}$ WD

Fig. 5-7. Detail of Fig. 5-3, Healing Ratio vs. initial water flow of CA specimens with w/c of 0.45. 


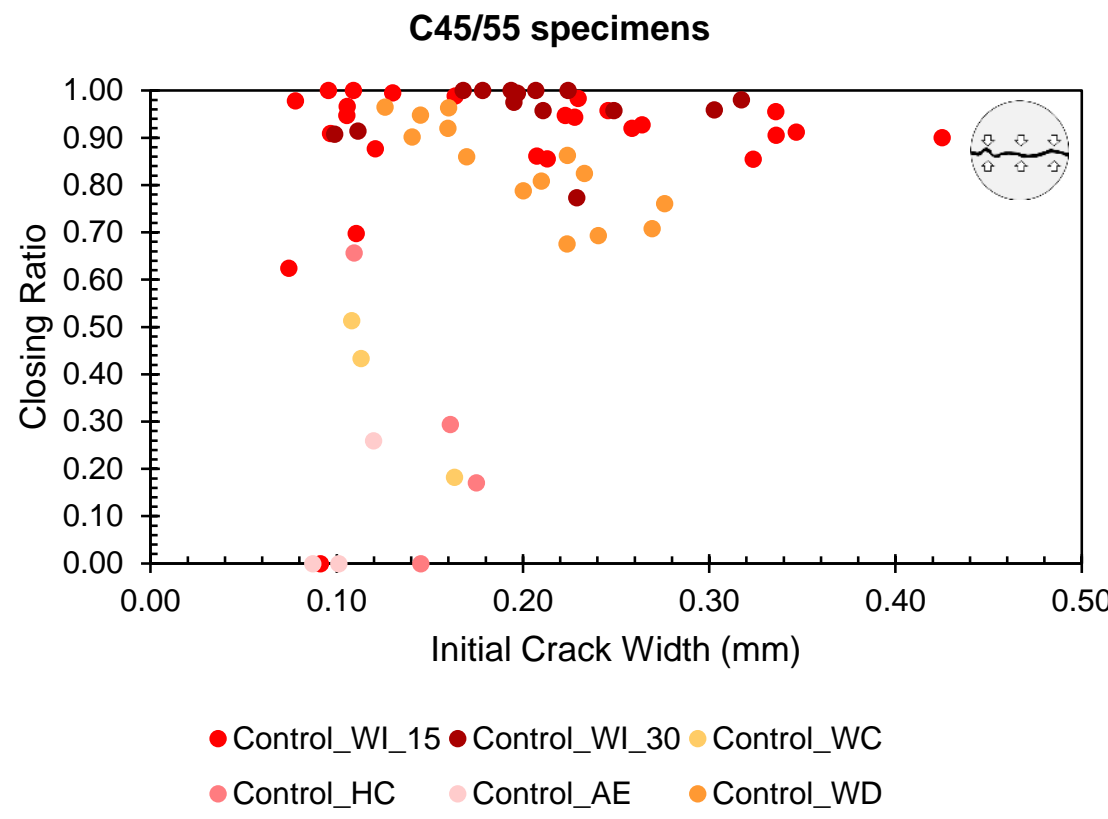

Fig. 5-8. Detail of Fig. 5-4, Closing Ratio vs. initial crack width of control spec. with w/c of 0.45.

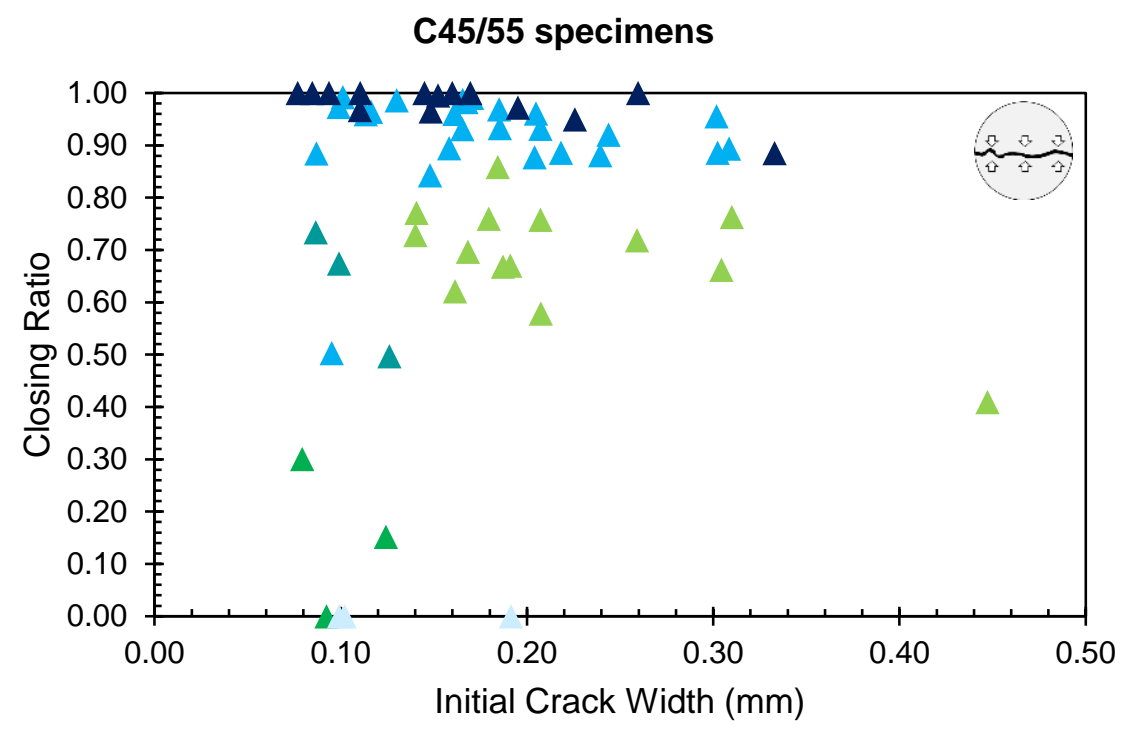

$\triangle$ CA_WI_15 $\triangle$ CA_WI_30 $\triangle$ CA_WC $\triangle$ CA_HC $\triangle$ CA_AE $\triangle$ CA_WD

Fig. 5-9. Detail of Fig. 5-4, Closing Ratio vs. initial crack width of CA specimens with w/c of 0.45. 
This comprehensive study has compared the effect of different types of healing exposures in self-healing in concrete by means of crack closing and water permeability, with the objective of comparing the effect of adding a crystalline admixture in the mix.

Water immersion exposures (at 15 and $30^{\circ} \mathrm{C}$ ) achieved the best results for both, autogenous healing and with crystalline admixtures. No recoveries were achieved in air exposure or humidity chamber neither by means of crack closing nor water permeability.

That means that for structures under cycling regimes (with periods under water immersion and drying periods) healing phenomena is not effective for achieving a proper response. This contrasts with some of the results described in the state of the art, where specimens under the exposure of wet/dry cycles registered as more efficient than water immersion. It was registered that a few specimens stored in low humidity exposures had negative Healing Ratio (represented as 0), which can be produced by the lack of moisture and shrinkage of specimens, increasing crack width.

There are no references concerning the water permeability and crack closing self-healing efficiency of CA under the different exposures available in the literature, but the results are coherent with the mechanical results obtained by Granger et al. (2005), Ter Heide (2005), Schlangen, et al. (2006) or Qian, et al. (2009) who obtained better mechanical recoveries of concrete healing under water immersion compared with those were stored in air.

\section{Efficiency of the crystalline admixture in water immersion}

A more detailed analysis on the effect of the initial damage was performed using specimens stored under water immersion at $15^{\circ} \mathrm{C}$, for both mixtures, since they are the groups with the higher number of specimens and it is the most studied exposure in the literature.

Regarding the effect of crystalline admixtures, it can be seen from results that for specimens with w/c ratio of 0.45 and stored under water immersion at $15^{\circ} \mathrm{C}$, there was an enhancement of the healing properties. This enhancement was produced by improving the minimum Healing Ratio (Fig. 5-10). The maximum value of Healing Ratio was not increased by the addition of CA, as there are also control specimens with Healing Ratio of almost 1.00. In this way, the effect of the crystalline admixtures on self-healing seemed to be an increase in the stability of the phenomenon.

Regarding Crack Closing Ratio, (Fig. 5-11) no improvements were reported by the introduction of the crystalline admixture. 


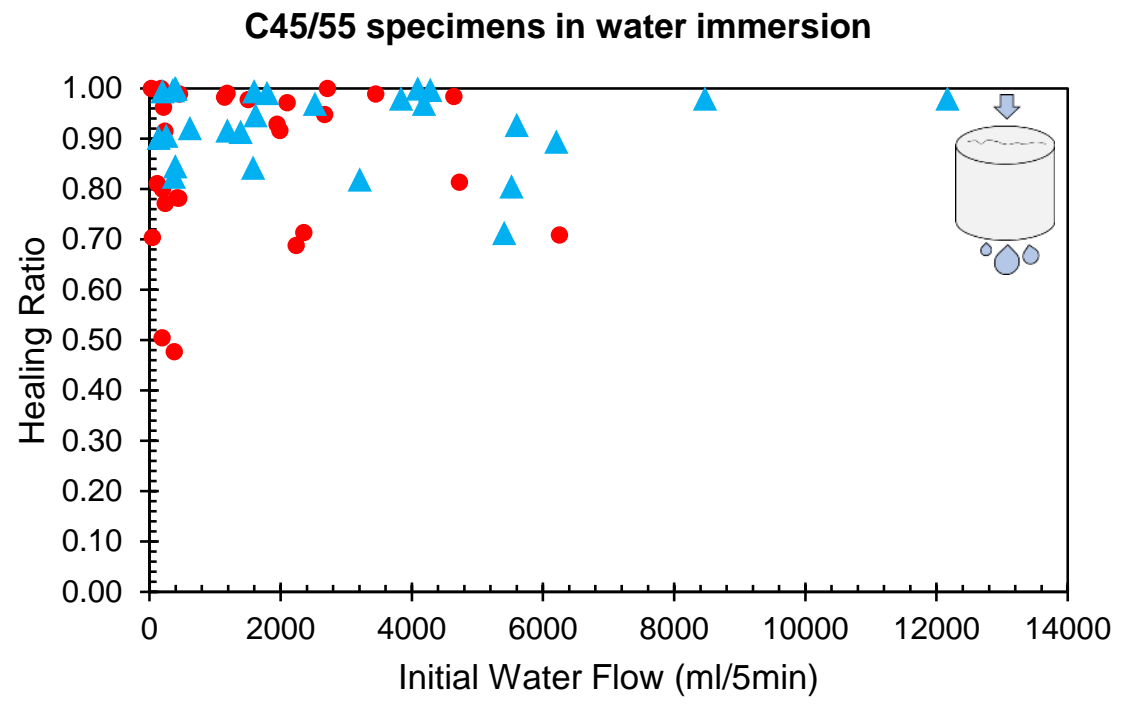

- Control_WI_15_W/C=0.45 $\triangle$ CA_WI_15_W/C=0.45

Fig. 5-10. Healing Ratio vs. initial water flow of specimens stored under WI at $15^{\circ} \mathrm{C}$ with $\mathrm{w} / \mathrm{c}$ of 0.45 .

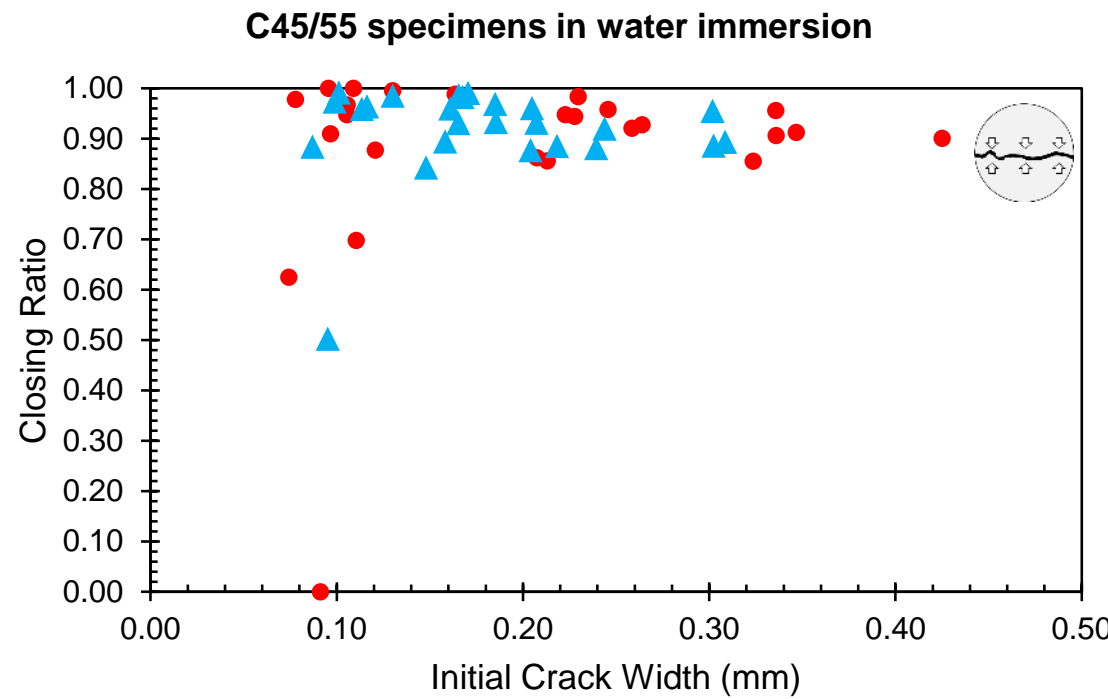

- Control_WI_15_W/C=0.45 $\triangle \mathrm{CA}$ _WI_15_W/C=0.45

Fig. 5-11. Closing Ratio vs. initial crack width of spc. stored under WI at $15^{\circ} \mathrm{C}$ with w/c of 0.45 . 


\section{Discussion about the effect of initial damage under water immersion}

As it has been explained in the state of the art, the more damaged a specimen is, the smaller healing properties it will present. However, there was no agreement between the limit values of initial damage in order to achieve complete healing. In this research, cracks up to $0.40 \mathrm{~mm}$ have been analyzed (around $13000 \mathrm{ml} / 5 \mathrm{~min}$ ).

Fig. 5-10 showed the obtained values of Healing Ratios for permeability tests for these groups. As it was expected, in general, specimens critically damaged achieve lower Healing Ratios than those with smaller damages. There is an exception for very small cracks, where there is a high dispersion of results, presenting lower Healing Ratio results.

For specimens under water immersion, Healing Ratio can be notable even for specimens with large damages. Specimens with initial water flow higher than 4000-5000 $\mathrm{ml} / 5 \mathrm{~min}$ are unlikely to heal completely. That water flow represents an initial crack opening around 0.30 $\mathrm{mm}$.

More specifically, Fig. 5-12 shows the Healing Ratio results for initial water flows under $3000 \mathrm{ml} / 5 \mathrm{~min}$ (which is approximately a crack opening of $0.25 \mathrm{~mm}$ ). This graph clearly shows the high dispersion for control specimens of low initial water flows, up to 500 $\mathrm{ml} / 5 \mathrm{~min}$, which represents a crack width around 0.1-0.15 mm, with better behavior for specimens with crystalline admixtures, essentially produced by a higher minimum value of Healing Ratio. In the whole, a more stable response has been achieved after that threshold, in which, as it was expected, the results decrease slowly when increasing the damage.

\section{Specimens with small cracks in water immersion}

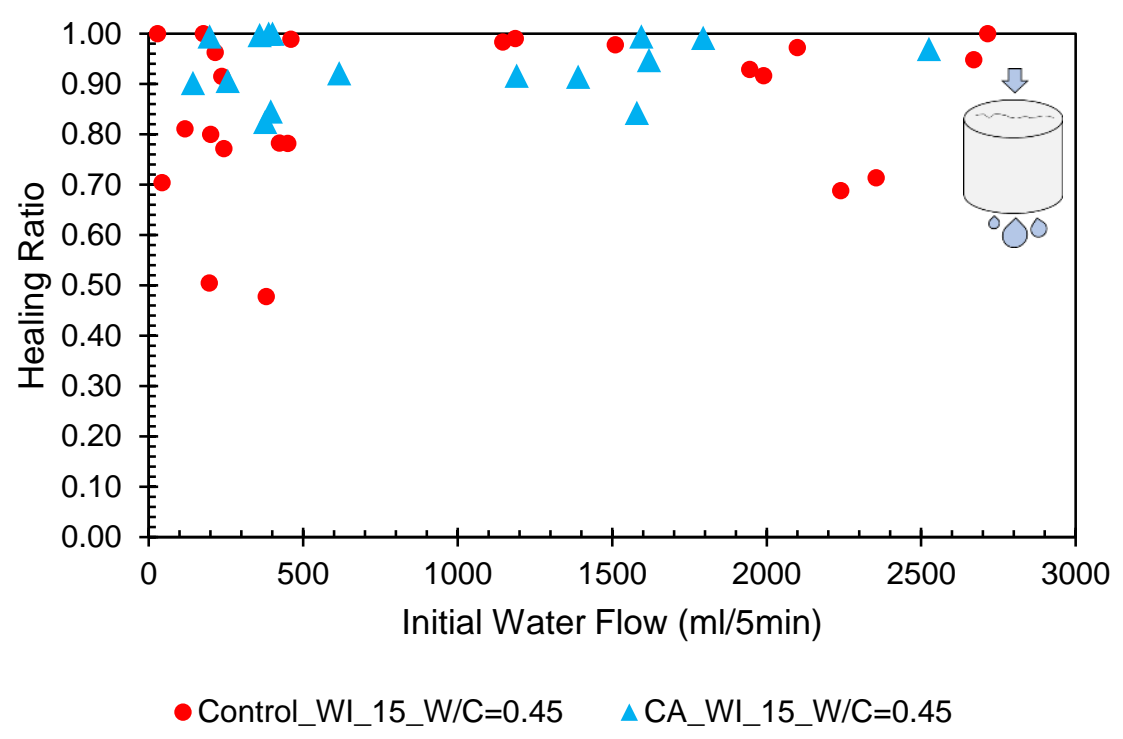

Fig. 5-12. Detail of Fig. 5-1 for specimens with small initial water flow in water immersion at $15^{\circ} \mathrm{C}$. 
The Closing Ratios were shown in Fig. 5-11. They are notably higher than Healing Ratio, but they follow the same general trends, e.g., specimens with cracks larger than 0.25-0.30 $\mathrm{mm}$ were unlikely to heal completely after 42 days of exposure under water immersion at $15^{\circ} \mathrm{C}$. Closing Ratios also present a high dispersion for very small crack widths.

The high dispersion obtained for smaller initial damages in both parameters could be caused by the precision limits of the method or by the existence of a damage threshold for recovering properties, as it has been indicated in some studies from the literature. This aspect should be further investigated in order to verify the origin of this phenomenon.

Considering Healing Ratio higher than 0.90 as a good self-healing, it can be said that for both, autogenous and crystalline-based specimens, $0.3 \mathrm{~mm}$ cracks are the limit for achieving a good healing when exposed to water immersion during 42 days. This conclusion seem consistent for both autogenous healing and self-healing based on crystalline admixtures.

Regarding the maximum healable crack by autogenous healing Edvardsen (1996; 1999), Fagerlund and Hassanzadeh (2010) or (Nishiwaki et al., 2012) concluded that cracks 0.30 $\mathrm{mm}$ were able to heal by carbonation, while other studies showed healing limited to cracks around 0.05 mm (Yang et al., 2009), Qian, et al. (2009) Snoeck and De Belie (2012) Kim, et al. (2014).

The results obtained in this thesis are aligned with the first group, even when using crystalline admixtures (which contrasts with the results by Sisomphon, et al. (2012)), which also improved the stability for cracks larger than $0.1 \mathrm{~mm}$ in terms of water permeability, unlike in the crack closing studies by Jaroenratanapirom and Sahamitmongkol (2011), but was also noticeable in that small range.

In the literature, Sisomphon, et al. (2012), reported as a limit of the self-healing capability of crystalline admixture cracks widths of 150 microns (for 30 days of water immersion), in terms of water permeability. They obtained better responses for the cases of using expansive admixtures, or a combination of $\mathrm{CA}$ and expansive admixtures. Jaroenratanapirom and Sahamitmongkol (2011) only obtained an improvement of using crystalline admixtures in terms of visual closure for small and early age cracks $(<0.1 \mathrm{~mm}$ and 3 days) in comparison to OPC mortars. However, this study shows that CA increases the stability of the healing response in terms of water permeability, while crack closing is comparable in all the groups, as shown in Fig. 5-11.

\section{Effect of water temperature}

Increasing the temperature of water to $30^{\circ} \mathrm{C}$ quickened the reaction (see Fig. 5-13), and the results show that in this case all specimens with CA achieved Healing Ratio above 0.95, which is almost perfect healing. Control specimens also achieved better overall results, but a bit of dispersion remains. One outlier corresponding to the control group was obtained, with a Healing Ratio of 0.20 . This specimen obtained a Sealing Ratio of 0.91 , this means that the crack was visually closed in the points measured, but the water flow was very similar before and after healing. Other specimens with similar initial water flow had better Healing Ratio, hence, this outlier is assumed to be produced by the randomness of autogenous healing. In fact, specimens with CA had stable results with Healing Ratios over 0.98 up to initial water flow values of $5000 \mathrm{ml} / 5 \mathrm{~min}$, which is approx. a $0.30 \mathrm{~mm}$ crack 


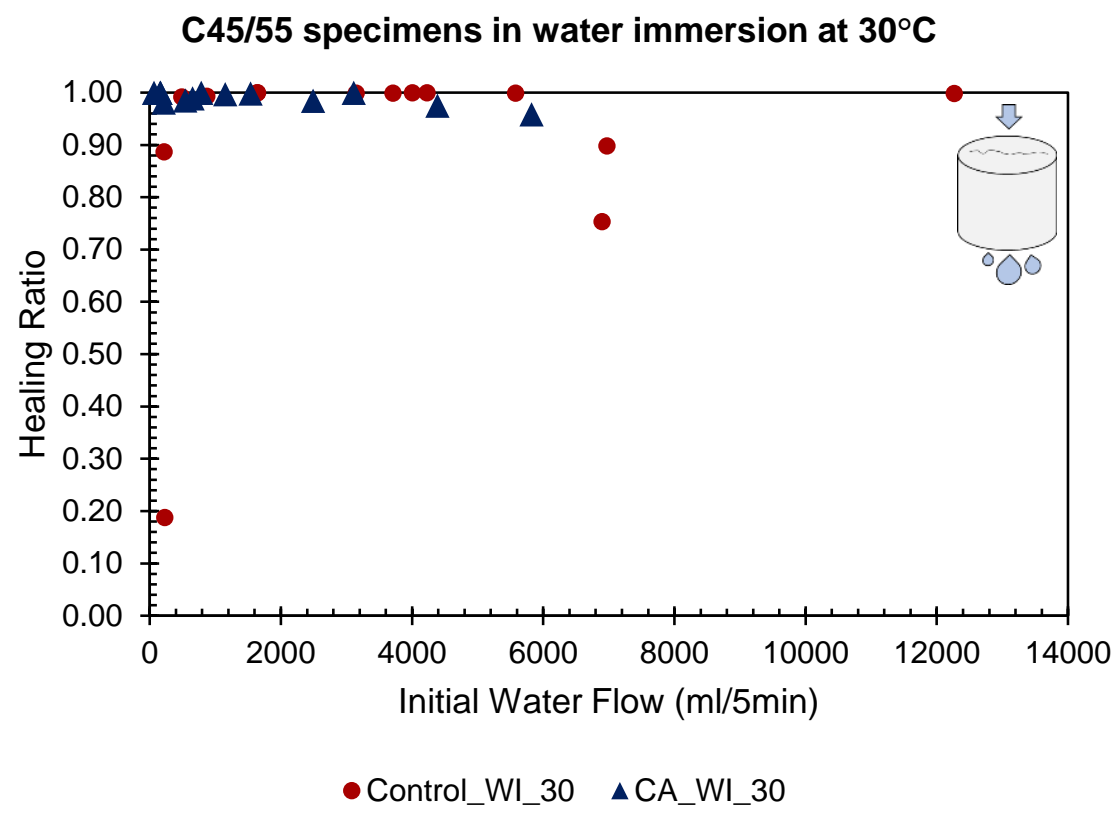

Fig. 5-13. Healing Ratio vs. initial water flow of specimens stored under WI at $30^{\circ} \mathrm{C}$ with $w / c$ of 0.45 .

Similarly to the results obtained by Reinhardt and Joss (2003) and Na et al. (2012), increasing the temperature of water from 20 to 40,50 and $80^{\circ} \mathrm{C}$, increased autogenous healing. This study also confirms this trend for the mixes containing crystalline admixtures.

\subsubsection{Effect of water/cement ratio and cement content}

One of the objectives of this research was to evaluate the effect of water/cement ratio and cement content for both autogenous healing and crystalline-based self-healing. Fig. 5-14 and Fig. 5-15 show the Healing and Closing Ratios results for the groups, with w/c ratio of 0.60 , where it can be seen that the Closing Ratio has a clearer decrease when increasing the damage (or initial crack width). This happens but with less clarity with the Healing Ratio, and no significant improvements can be detected by the use of the crystalline admixture.

More specifically, dividing graphs in one for control specimens and the second for specimens with CA (Fig. 5-16 and Fig. 5-17, respectively) differences for autogenous healing are not notable, but the group with w/c ratio of 0.60 showed slightly better behavior. On the contrary, the trend was the opposite for specimens with $\mathrm{CA}$, with w/c = 0.45 specimens seemingly behaving better, according to the permeability tests. Nevertheless, it should be noted that differences from the different mixtures are not relevant. 


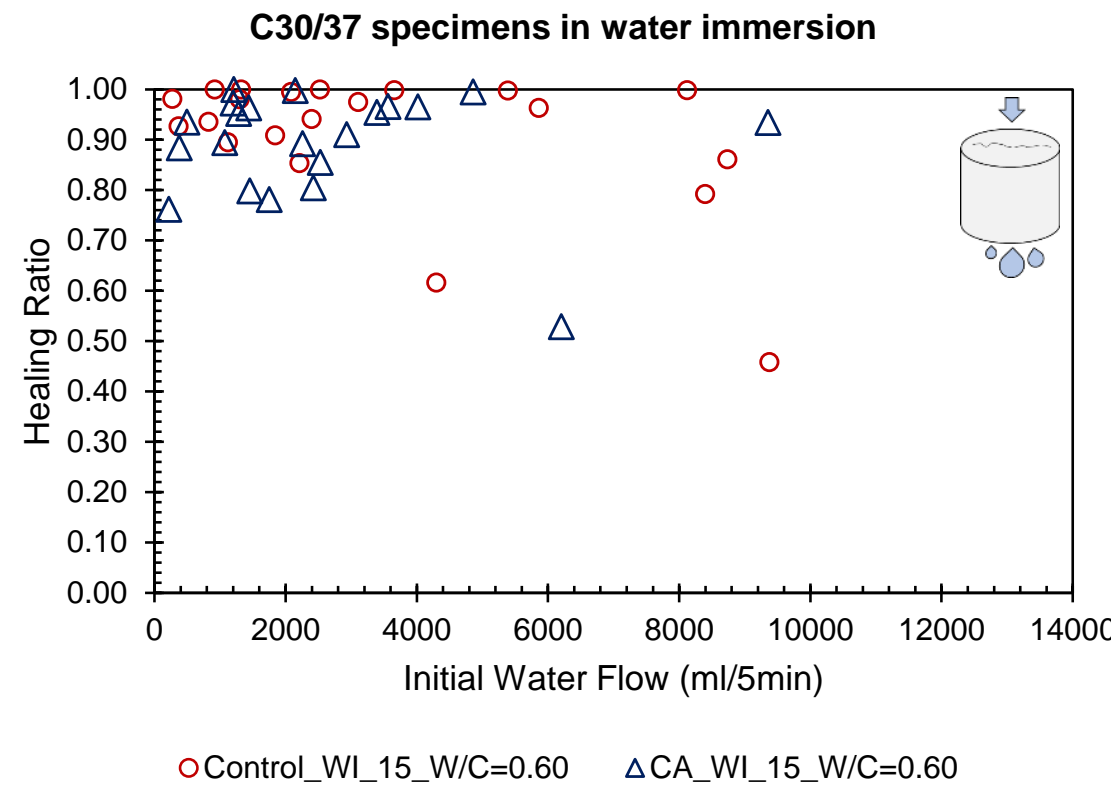

Fig. 5-14. Healing Ratio vs. initial water flow of specimens stored under WI at $15^{\circ} \mathrm{C}$ with $w / \mathrm{c}$ of 0.60 .

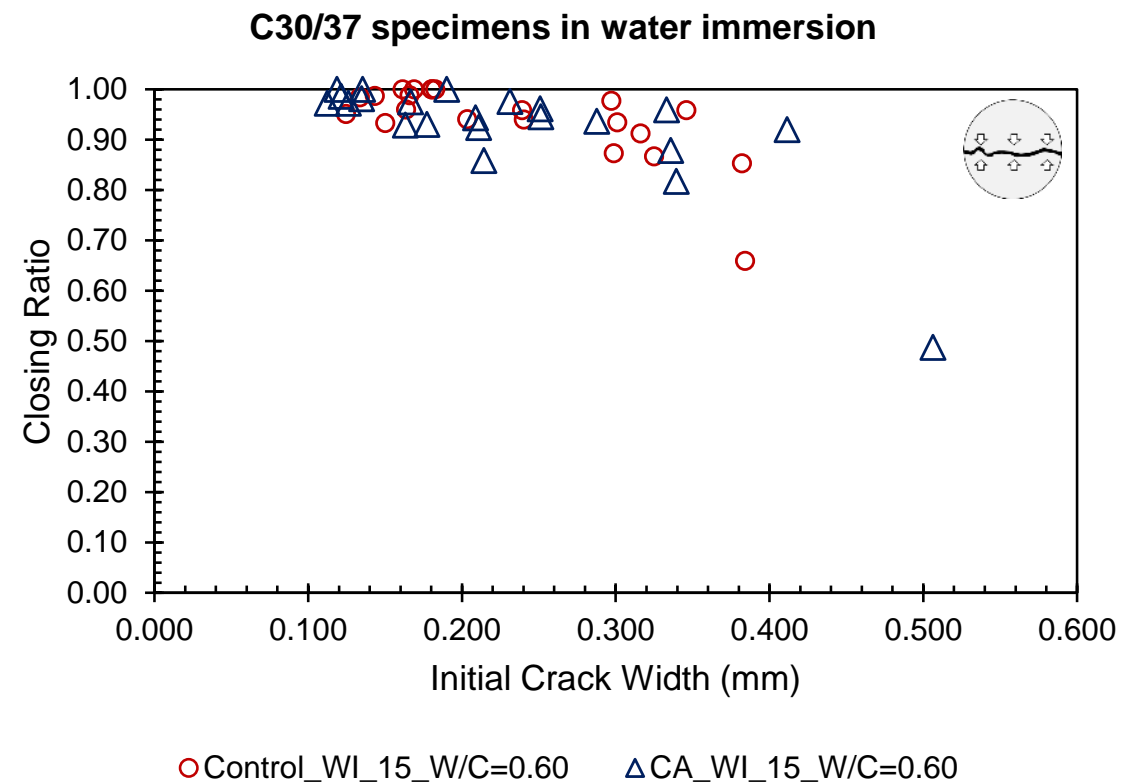

Fig. 5-15. Closing Ratios vs. initial crack width of specimens stored under water immersion at $15^{\circ} \mathrm{C}$. 


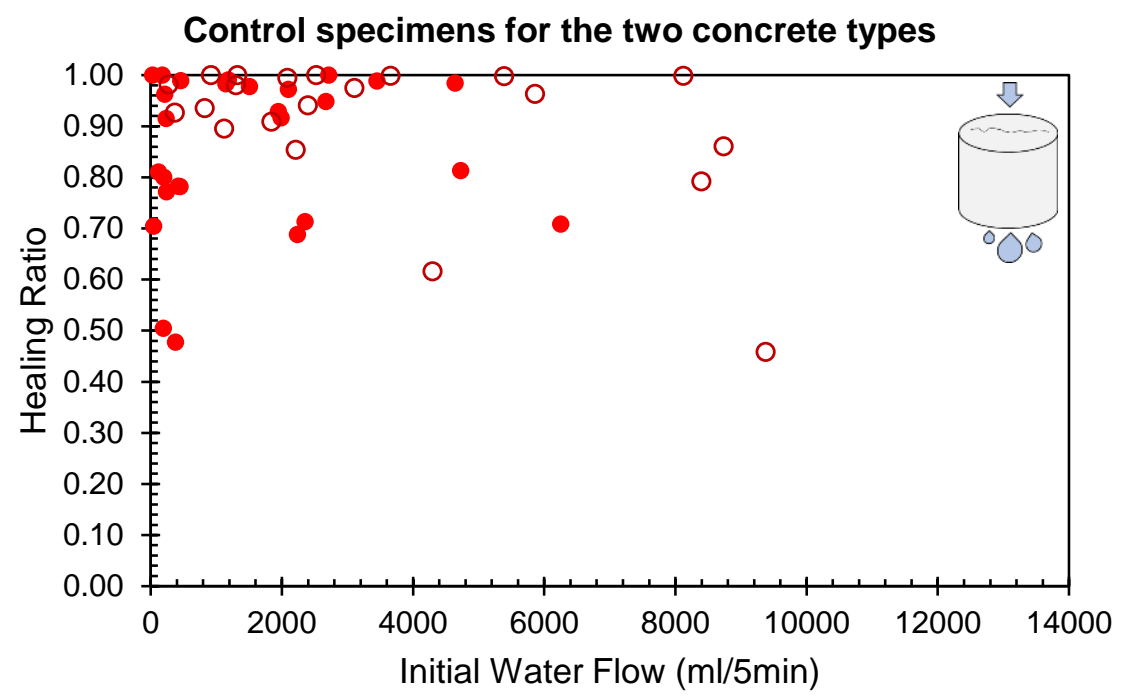

- Control_WI_15_W/C=0.45 OControl_WI_15_W/C=0.60

Fig. 5-16. Healing Ratio vs. initial water flow of control specimens stored in WI_15 with w/c of 0.45 and 0.60. Results combined from Fig. 5-10 and Fig. 5-14.

CA specimens for the two concrete types

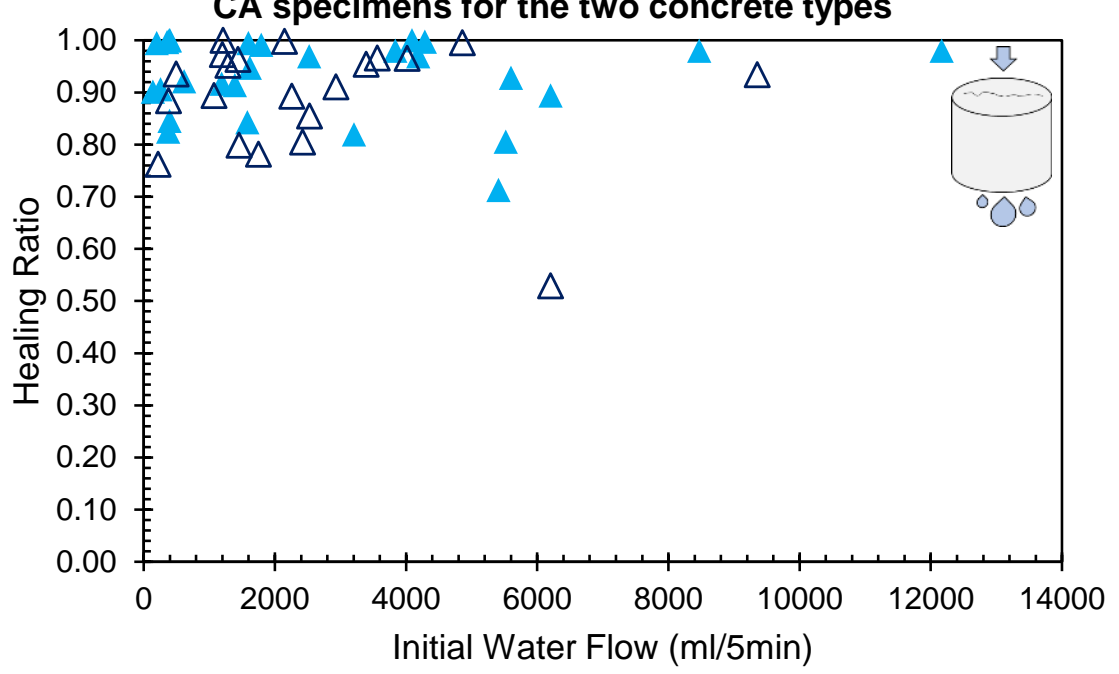

$\triangle$ CA_WI_15_W/C $=0.45 \Delta$ CA_WI_15_W/C $=0.60$

Fig. 5-17. Healing Ratio vs. initial water flow of CA specimens stored in WI_15 with w/c of 0.45 and 0.60. Results combined from Fig. 5-10 and Fig. 5-14. 
Regarding the variations on autogenous healing when changing water/cement ratio or cement content, Qian, et al. (2009) obtained slight variations, Gagné and Argouges (2012) found no differences comparing w/c of $0.35,0.45$ and 0.60 , while Van Tittelboom, et al. (2012) found for two water/binder ratios of 0.40 and $0.50 \mu \mathrm{m}$ that increasing w/c ratio decreased healing by continuing hydration. The results obtained in this study are coherent with those obtained by Gagné and Argouges (2012) with no significant differences.

\subsubsection{Comparison between parameters}

Throughout this section, Closing Ratios were usually shown to be higher than Healing Ratios. This difference is of great importance in order to define a methodology of analysis for self-healing.

The values for both parameters can be compared for the different groups, showing that control specimens were more likely to present higher Closing Ratios that do not correspond with higher Healing Ratios. This can be seen in Fig. 5-18, which displays values for specimens under water immersion at $15^{\circ} \mathrm{C}$ and WD cycles. One outlier was obtained in the Control group, which had no closing of the crack but experienced a water flow reduction, that could have been produced by autogenous healing reactions in the interior of the crack.

\section{Comparison Healing - Closing Ratios}

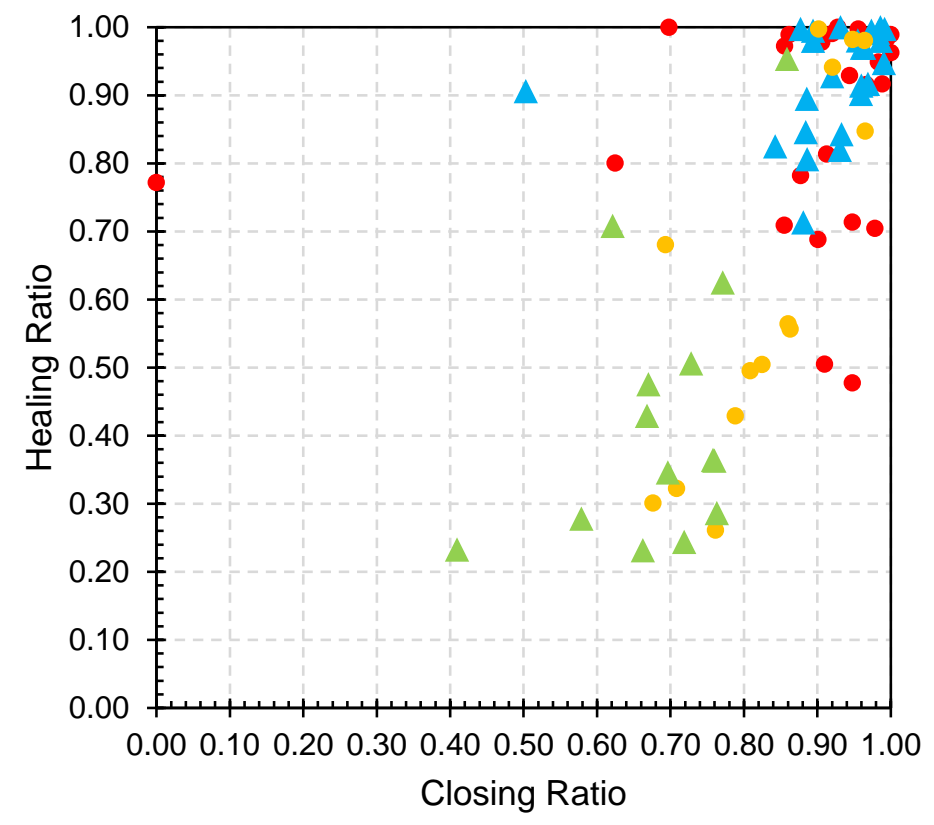

- Control_WI_15 $\triangle$ CA_WI_15 Control_W/D $\triangle$ CA_W/D

Fig. 5-18. Healing Ratio vs Closing Ratio for control and CA specimens with w/c ratio of 0.45 exposed to water immersion at $15^{\circ} \mathrm{C}$ and exposed to WD cycles. 
Chapter 5. Efficiency of autogenous healing and autonomous healing with crystalline admixtures

It should be noted that specimens under water immersion achieved higher healing and Closing Ratio, while specimens under wet/dry cycles achieved notably worse results. The lower relation between both parameters for the WD exposure could be interpreted as an incomplete healing process in comparison to the WI exposure. As it was seen in Fig. 5-13 the results for water immersion at $30^{\circ} \mathrm{C}$ were even higher than for those at $15^{\circ} \mathrm{C}$, which indicates a possible further development in time of healing phenomena.

The differences between both parameters is of major importance as many studies reported in the state of the art only compared the visual closure of cracks. The study of permeability properties offers more information of the durability properties of concrete structures presenting cracks and their possible healing.

Comparing the values obtained for the two mix compositions (Fig. 5-19), it can be seen that there were no notable differences.

\section{Healing-closing ratio: control}

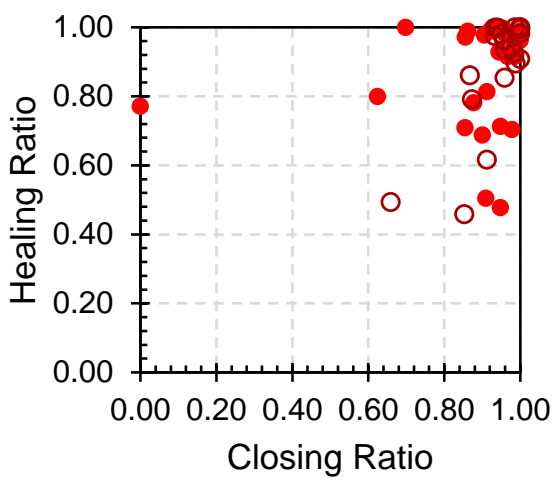

- Control_WI_15_W/C=0.45

OControl_WI_15_W/C=0.60

\section{Healing-closing ratio: CA}

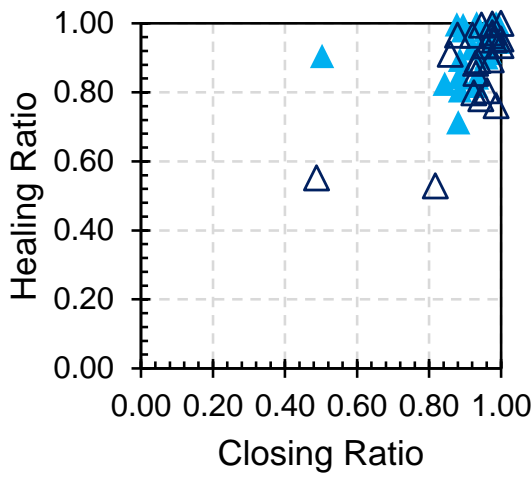

$\triangle$ CA_WI_15_W/C=0.45

$\triangle$ CA_WI_15_W/C=0.60

Fig. 5-19. Healing Ratio vs Closing Ratio for control (left) and CA (right) specimens with w/c ratio of 0.45 and 0.60 , exposed to water immersion at $15^{\circ} \mathrm{C}$.

\subsection{Mechanical recovery}

This section shows an experimental campaign performed to analyze the mechanical recovery produced with and without crystalline admixture (Type B) in a high dosage and healing under the optimal conditions detected by means of water permeability and crack closing. These conditions were decided in order to maximize the self-healing effect and see if any change of property can be detected as produced by self-healing. 


\subsubsection{Effect of CA in optimal conditions}

CA type B in type of concrete C45/55 was used, which composition was displayed in Table 5-1. These specimens were also used in one of the campaigns from the tests for the validation of the methodology.

Three point bending test has been used for creating the damage and evaluating the properties before/after the healing process. The amount of CA was decided in $8 \%$ by the weight of cement and the healing exposure decided to evaluate self-healing has been water immersion at $30^{\circ} \mathrm{C}$, since it has achieved the highest results in the previous sections. The values of these two parameters have been fixed with the purpose of maximizing the strength recovery values, in order to verify if strength recoveries can be measured when using crystalline admixtures. After the results obtained in Chapter 4, the expected improvements will come from a better stiffness due to an improvement of the bond fiber matrix, rather than by a strict stiffness recovery produced by a filling material that strongly bonds the two concrete surfaces.

The age of precracking and beginning of the healing process were fixed at the age of 2 days. The healing time decided for this study have been 2 months (56 days). The target crack width, as similar in the rest of the work, has been fixed to maintain load until crack opening reaches approx. $0.30 \mathrm{~mm}$. Table 5-2 shows the experimental program for the mechanical regain study, with a total of 12 specimens.

\begin{tabular}{ccc}
\hline & \multicolumn{2}{c}{ Healing exposure } \\
\hline Admixture & Humidity Chamber & Water Immersion \\
\hline None & 3 specimens & 3 specimens \\
\hline $\mathbf{8} \%$ of CA type B & 3 specimens & 3 specimens \\
\hline
\end{tabular}

Table 5-2. Experimental program for the evaluation of the mechanical recovery.

This campaign will allow to compare with different mechanical parameters the improvements produced by autogenous healing and by introducing crystalline admixtures on the mix.

The results obtained in this experimental study, showed that specimens did not experience a new peak in the reloading load-displacement curve, which indicates that the precipitates inside the crack do not produce a noticeable recovery of the mechanical properties of the concrete matrix. Because of that, the parameters that will be used for the analysis are (described in detail in Section 3.4 - Mechanical ) the stiffness recovery and the regain of area or energy.

Comparing the values of precracking and reloading slopes for control and CA specimens (Fig. 5-20 and Fig. 5-21), it can be said that control specimens had higher initial values of precracking and reloading stiffness, independently of the exposure conditions. Specimens with crystalline admixtures show an improvement of the stiffness for specimens healed underwater (CA-WI) compared to those healed in humidity chamber (CA-HC), while control specimens have almost identical reloading stiffness for those specimens healed in humidity chamber (Control-HC) and those healed underwater (Control-WI). 


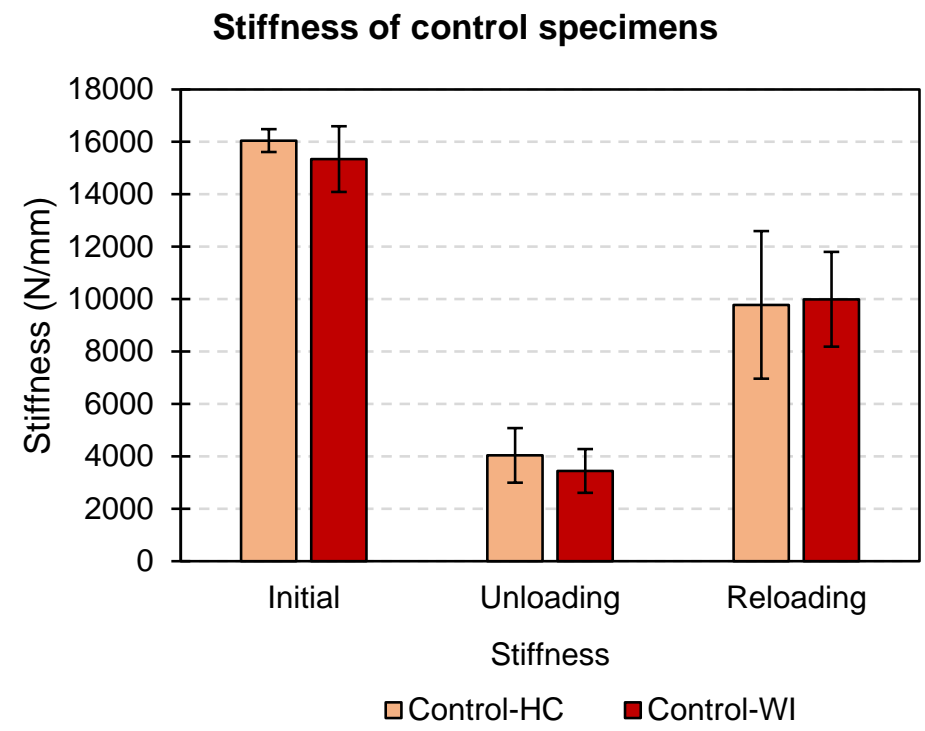

Fig. 5-20. Average and standard deviation values for precracking, unloading (tangent) and reloading slopes for control specimens.

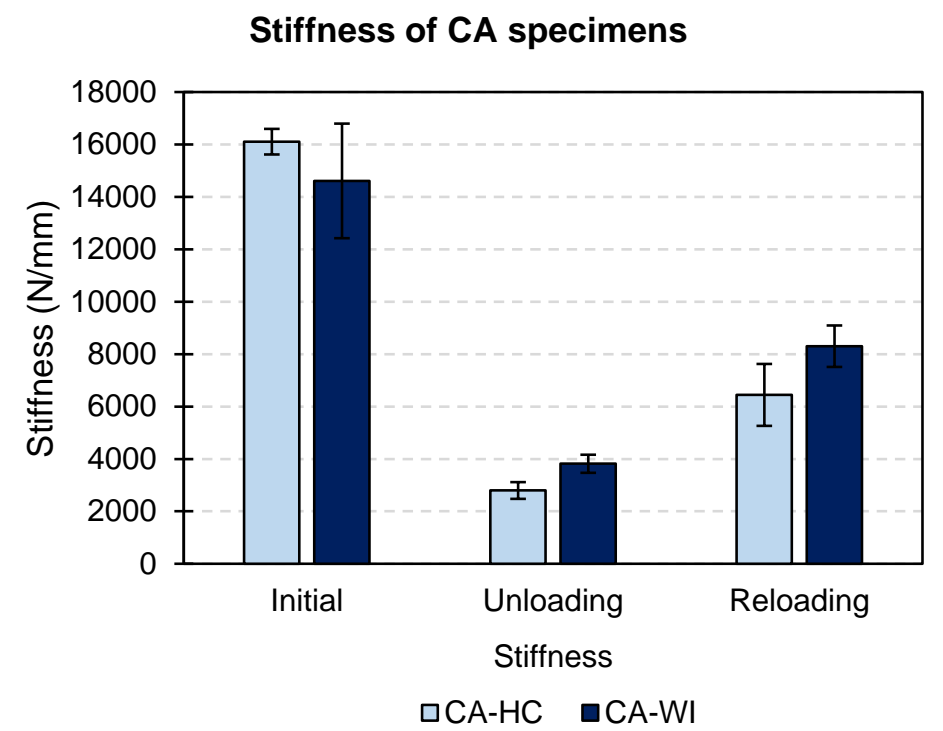

Fig. 5-21. Average and standard deviation values for precracking, unloading (tangent) and reloading slopes for specimens with $8 \%$ of CA type $B$. 
The recoveries obtained in stiffness, calculated using the equation 4.1 , indicate that the average stiffness recovered in the group with $\mathrm{CA}$ is greater when comparing the group healed in WI in respect to the group healed in $\mathrm{HC}$, but the final value is not greater than that obtained for control specimens (see values in Table 5-3). Therefore, these improvements have a relative relevance from the mechanical point of view.

\begin{tabular}{ccccccc}
\hline \multicolumn{7}{c}{ Stiffness recovery } \\
\hline & Healed for 2 months in HC & Healed for 2 months at WI_30-C \\
\hline Spec.1 & Spec.2 & Spec.3 & Spec.1 & Spec.2 & Spec.3 \\
\hline Control & $73,2 \%$ & $40 \%$ & $71 \%$ & $69 \%$ & $68 \%$ & $57 \%$ \\
\hline CA & $48 \%$ & $41 \%$ & $31 \%$ & $68 \%$ & $56 \%$ & $48 \%$ \\
\hline \multicolumn{7}{c}{ Table 5-3. Results of the evaluation of the stiffness recovery. }
\end{tabular}

Comparing the values of precracking and reloading areas under the curve loaddisplacement for control and CA specimens and calculating the regain of area as explained in section 3.4 Mechanical, and specifically in 3.4.1.3 subsection Energy, specimens healed in humidity chamber show little improvement after the healing condition for control and specimens with CA type B. The parameter of Regain of Area (Table 5-4) reflects for both groups an improvement of healing when specimens were submerged in water at $30^{\circ} \mathrm{C}$ (values higher than $100 \%$ ), while specimens healed in humidity chamber obtained values around $100 \%$, indicating a final area close to the initial. However, the results show that there is no improvement due to the presence of crystalline admixtures.

\begin{tabular}{ccccccc}
\hline \multicolumn{7}{c}{ Regain of Area } \\
\hline & Healed for 2 months in HC & Healed for 2 months at WI_30-C \\
\hline Spec. 1 & Spec.2 & Spec.3 & Spec.1 & Spec.2 & Spec.3 \\
\hline Control & $107 \%$ & $83 \%$ & $137 \%$ & $128 \%$ & $121 \%$ & $111 \%$ \\
\hline CA & $100 \%$ & $76 \%$ & $91 \%$ & $136 \%$ & $134 \%$ & $111 \%$ \\
\hline \multicolumn{7}{c}{ Table 5-4. Results of the evaluation of the regain of area. }
\end{tabular}

The reference accompanying specimens are precracked specimen healed at a humidity chamber and then, since the healing specimens were healed under water immersion at $30^{\circ} \mathrm{C}$, the different evolution of the bond between the reinforcement (in this case, fibers) and the concrete matrix may be affecting the results. But, from the results it can be concluded that there is no significant recovery of strength by autogenous healing neither by using this crystalline admixture type B in the dosage used.

These results are aligned with those published by Sisomphon et al. (2013), where no significant improvements were achieved when using CA (added in a much lower amount, only $1.5 \%$ by cement weight), and contrast with those reported by Ferrara et al. (2014), in which the presence of $1 \%$ of CA enhanced the mechanical behavior in concrete, or reported in lime mortars (De Nardi et al., 2016). These differences in the results might be produced by the difficulties explained in Chapter 4 regarding the methodology of evaluation, and by related processes that can be involved, such as the bond fiber-matrix or maturing effects. 


\subsection{Sorptivity}

Admixture type A was used for the tests, in a dosage of $4 \%$ by the weight of cement. CA was added by reducing the amount of sand accordingly. Six prismatic specimens per group were precracked and their self-healing capability was analysed by the capillary sorption or sorptivity test. The first casted group of the Control mix had some problems because of a bad compaction, and the first casted group of the CA mix because of a too early demoulding. Because of that, extra groups were casted for Control and CA to complete the groups that were healing under water immersion.

In total, 69 prismatic specimens were completely tested with sorptivity tests. The targeted crack size in the precracking process by means of three point bending test was $0.30 \mathrm{~mm}$, however, there has been detected some dispersion in the crack width, having most of them values between 0.30 and $0.40 \mathrm{~mm}$.

Specimens were left to heal at the age of 7 days during 28 days in the following three healing conditions: WI (water immersion at $15^{\circ} \mathrm{C}$ ), $\mathrm{HC}$ (Humidity chamber) and WD (wet/dry cycles), consisting on immersion in tap water at a temperature of $15^{\circ} \mathrm{C}$ for 7 days and humidity chamber for another 7 days; this process is repeated four times. Only specimens precracked at the age of 7 days could be used to analyse the efficiency of CA.

\subsubsection{Sorptivity and crack sorptivity}

Fig. 5-22 and Fig. 5-23 show the crack sorptivity values obtained for control specimens and the group with crystalline admixture type A after healing in the three conditions.

Control group exposed in wet/dry cycles had very large dispersion, and then its results may not be representative. The best results are achieved by the group with $\mathrm{CA}$ healed under water immersion, followed by the group with CA healed in WD cycles and afterwards, Control groups in water immersion and humidity chamber. As explained in Chapter 4, the differences between CA and CTRL specimens healed in humidity chamber could be produced by slight differences in damage.

Since the sorption of water produced through the area of the notch has been removed, this means that the area of the crack exposed absorbs less water after healing than before healing, presumably due to a densification of that area. This densification is different for each group, and it can be deduced that in control group in $\mathrm{HC}$ is produced by normal hydration in $\mathrm{HC}$, and in WI or WD by autogenous healing.

In contrast, for CA groups, under $\mathrm{HC}$ almost none reaction is produced by healing. This is coherent with the hydration quickening seen in calorimetry and compressive strength. The difference of results for WI and WD, which show a densification of the crack area, suggest a reaction by the admixtures in contact with water. Therefore, CA improve autogenous healing but to a limited extent. 


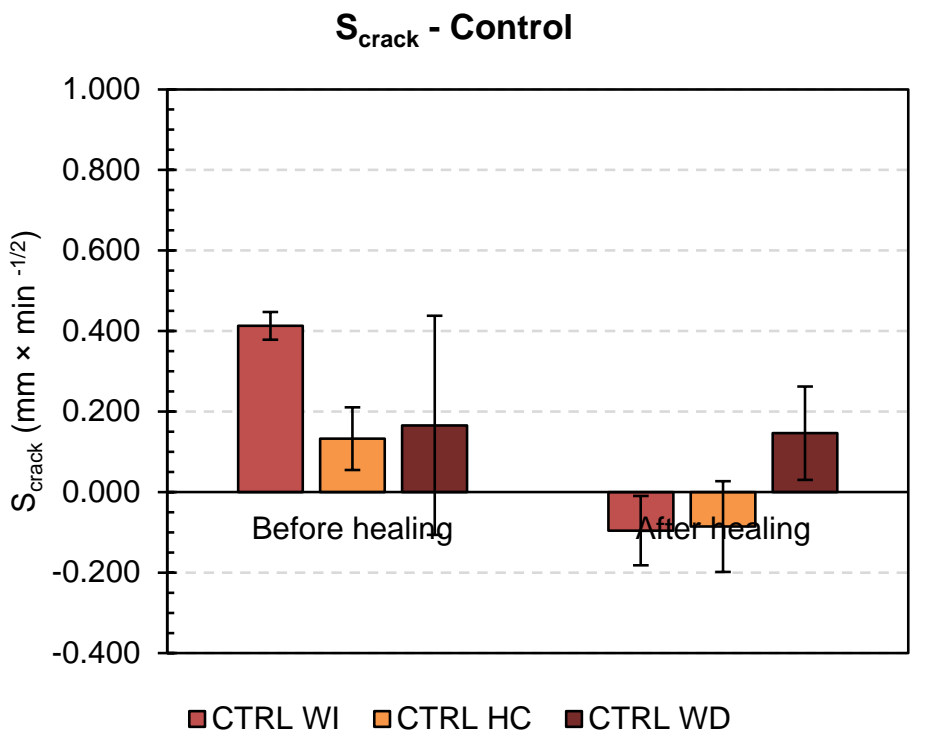

Fig. 5-22. Average and std. deviation results of crack sorptivity for control specimens.

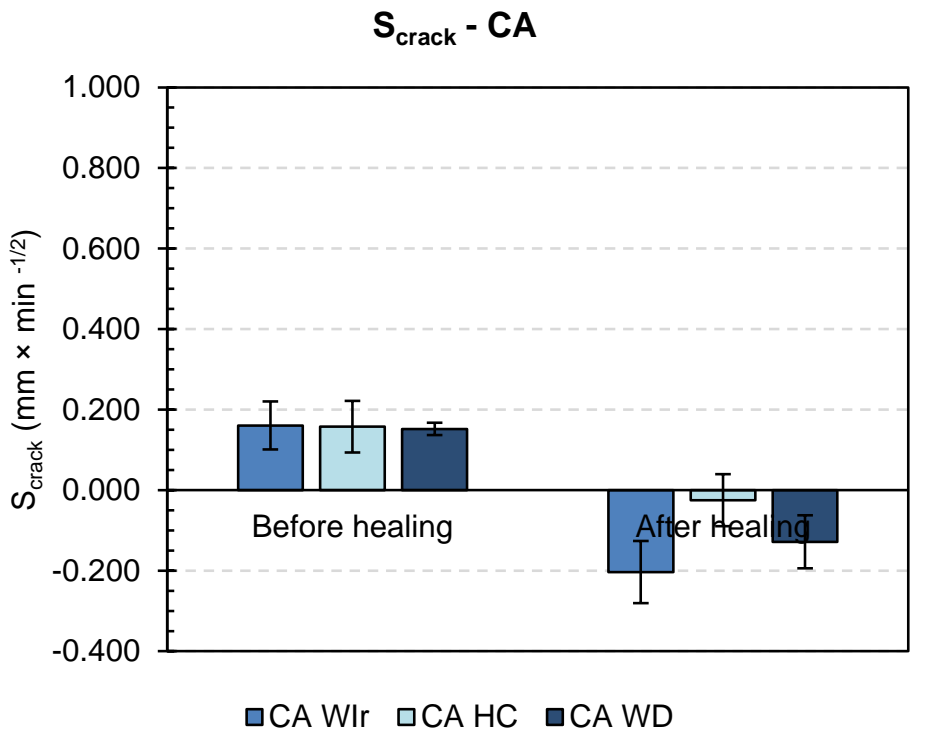

Fig. 5-23. Average and std. deviation results of crack sorptivity for CA specimens. 
CA specimens healed underwater achieve always negative values of $S_{\text {crack }}$ after healing. But since the initial $\mathrm{S}$ is different for each group, the improvement in sorptivity can be also

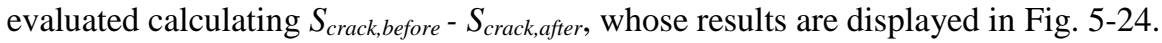

The results show that the best behavior corresponds to CTRL-WI > CA WI > CA WI. This means that specimens underwater got the best results, and control specimens had a larger improvement, and CTRL-WD the lowest. In this case, specimens in humidity chamber achieved similar results, and low improvements, which will be produced by hydration. Interestingly, CTRL-WD got the worst results but has too high dispersion (and thus its results are not completely reliable), while CA-WD achieved quite good results.

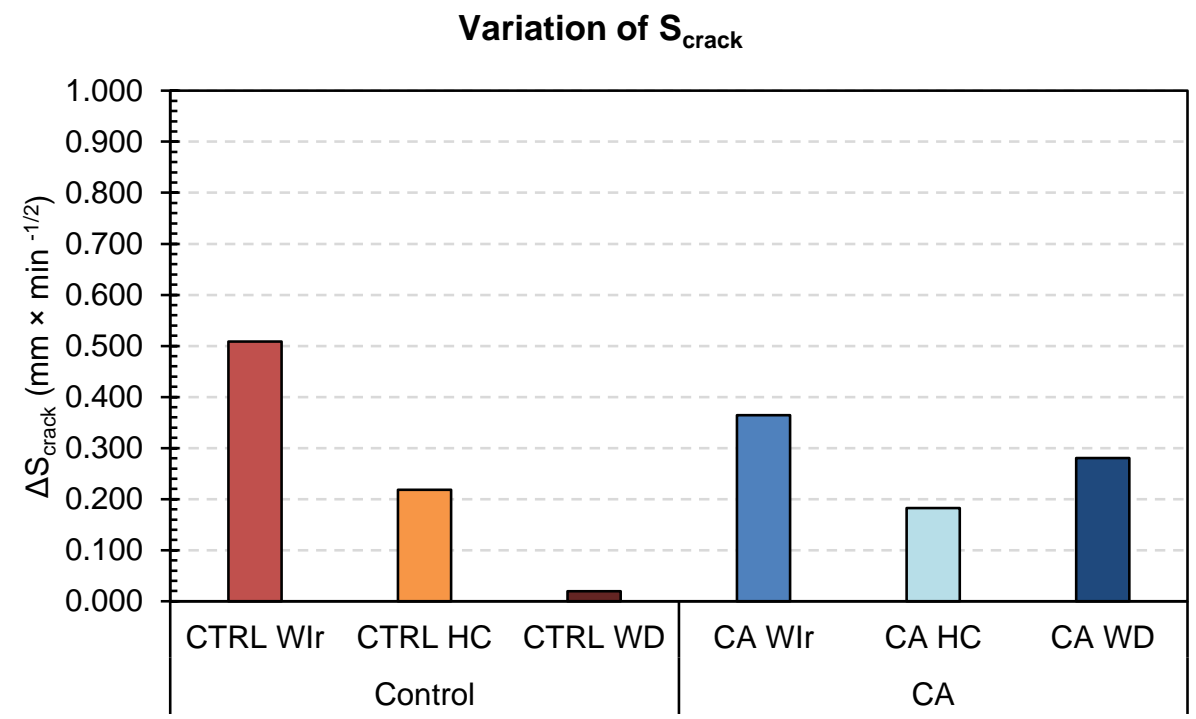

Fig. 5-24. Average results of crack sorptivity improvement for control and CA specimens.

\subsubsection{Initial Rate of Suction}

Initial Rate of Suction (IRS) evaluates the speed of water sorption during the first minute of exposition. Fig. 5-25 shows ISR index for each group, showing that before healing all groups have IRS between 1 and $2.4 \mathrm{~mm} \times \min ^{-1 / 2}$. 

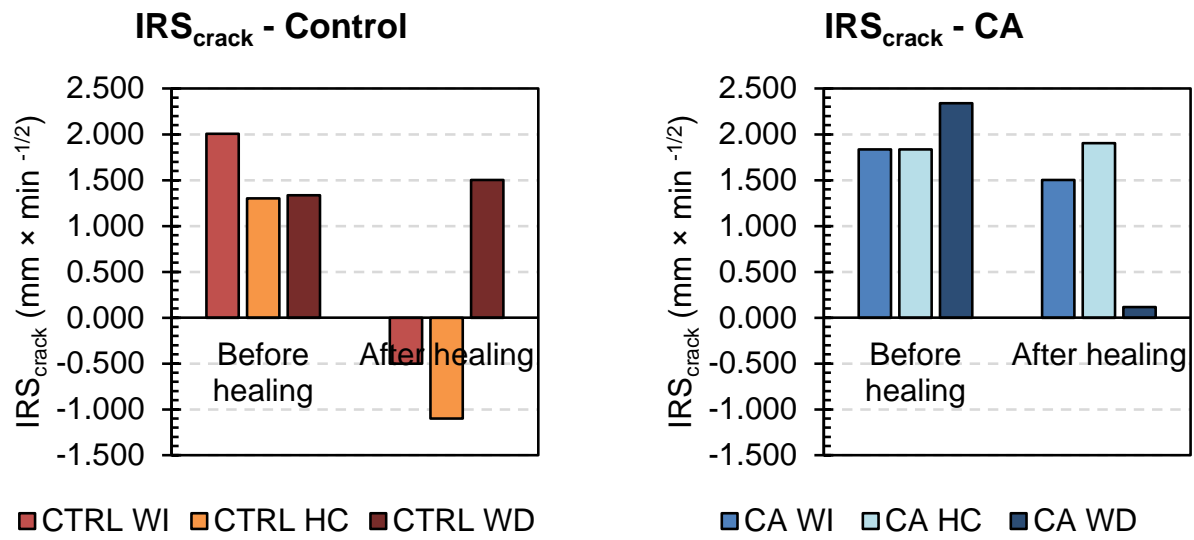

Fig. 5-25. Average results of Initial Rate of Suction for control (left) and CA (right) specimens.

After healing the results have much higher dispersion between groups (but with consistent results between specimens of a same group), CTRL-WD and CA-HC had high sorption when analysing both parameters, Sorptivity and IRS of the crack. Analogously, CTRL-WI and CTRL-HC had negative values, meaning that the crack is more impermeable than before healing, being similar results that when analysing $S_{\text {crack }}$ (even though in this case the lowest initial sorption corresponds to specimens in humidity chamber). CA specimens and CTRL-WD had the higher IRS, that is, they absorbed water much quickly during the first minute, and having the lowest $S_{\text {crack }}$ results, that means that they absorbed water during the very first minutes and stabilized quickly (during the first $16 \mathrm{~min}$ ). This can be also seen representing the graphs of $\mathrm{S}$ for the different times (Fig. 5-26).

\section{CTRL-WI - after healing}

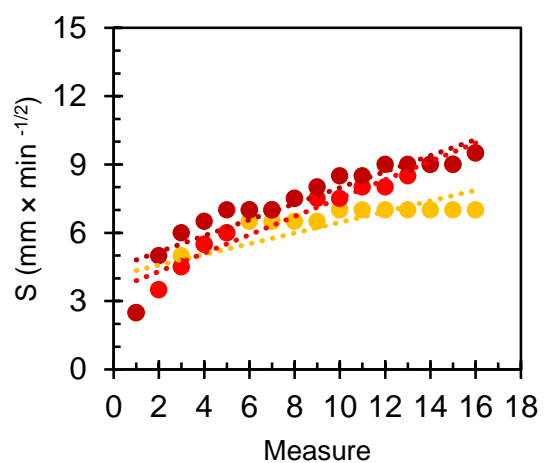

\section{CA-WI - after healing}

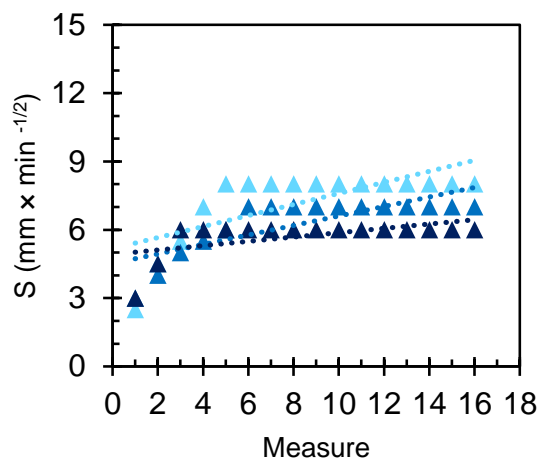

Fig. 5-26. Sorptivity evolution with measurements for precracked specimens healed underwater for control (left) and CA (right) groups. 
When looking at the S evolution for CTRL-HC, group which also got good results when analysing S, it can be seen that after 4 hours they are still absorbing water, similarly to CA$\mathrm{HC}$, which does not show a stabilisation during the test (Fig. 5-27).

\section{CTRL-HC - after healing}

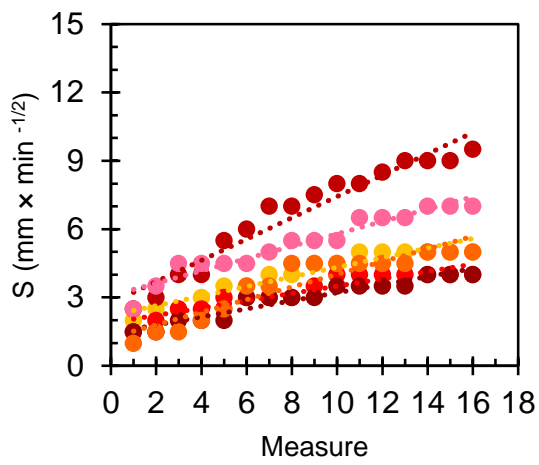

CA-HC - after healing

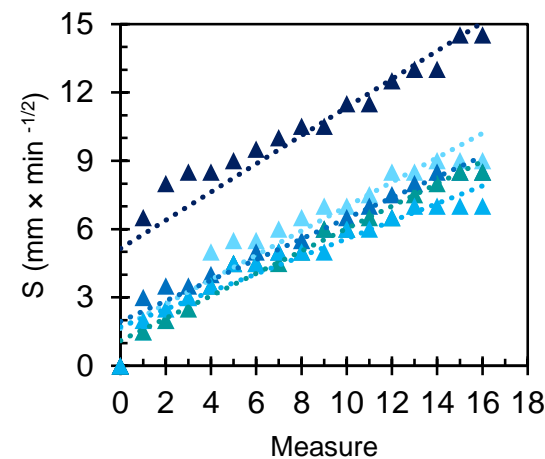

Fig. 5-27. Sorptivity evolution with measurements for precracked specimens healed in humidity chamber for control (left) and CA (right) groups.

This indicates that even though with the sorptivity index CA do not have a huge difference compared with control specimens, they achieve a quicker stability, while control specimens continue absorbing water after 4 hours of testing.

\subsection{Further insights about the healing reactions}

\subsubsection{Composition of the healing byproducts}

Studies performed with XRD showed that the precipitates for all tested samples (control and Type A, Type B) were composed by calcite and brucite especially and also some aragonite was detected. Since magnesium could be found in small amounts in the limestone powder and in the cement, finding brucite is not strange. The presence of brucite could be higher in the crystalline admixture Type B because of its higher content of magnesium oxide, but this was not analyzed in this work.

The fact that the byproducts are composed by calcium carbonate and brucite in all cases indicates that the products can all be produced by the carbonation of the outer layer, and no specific differenced compounds were detected when using crystalline admixtures. Because of that, the modifications of the healing mechanisms by using the crystalline admixtures can be produced in the rate of the healing reactions or the structure of the precipitates, but the basic composition will remain the same. This could be produced by autogenous healing being of higher magnitude than healing produced by crystalline admixtures, or because they have a similar type of reaction which produces the same type of byproducts. 


\subsubsection{Verification of the internal carbonation}

Since the main cause of the reactions taking place are thought to be continuing hydration and carbonation, phenolphthalein was used as an indicator to verify the internal carbonation of several specimens. Healed specimens used in 4.2.3 "Estimation of the healing speed and healable crack width in concrete" were cut transversally with a circular saw (Fig. 5-28).

Then, just after letting 30 min dry the surface of the specimens, phenolphthalein indicator was applied to the surface of all concrete specimens, showing no coloring differences, either for cracks of size $0.1 \mathrm{~mm}$ or size $0.35 \mathrm{~mm}$, healing under water immersion, wet/dry cycles or being stored in humidity chamber. Fig. 5-29 shows as an example the cross section of two specimens, one with a small crack of size $0.1 \mathrm{~mm}$ and "healed" in humidity chamber (left), and another with a large crack of size $0.3 \mathrm{~mm}$ healed in wet/dry cycles, in both cases for 42 days.

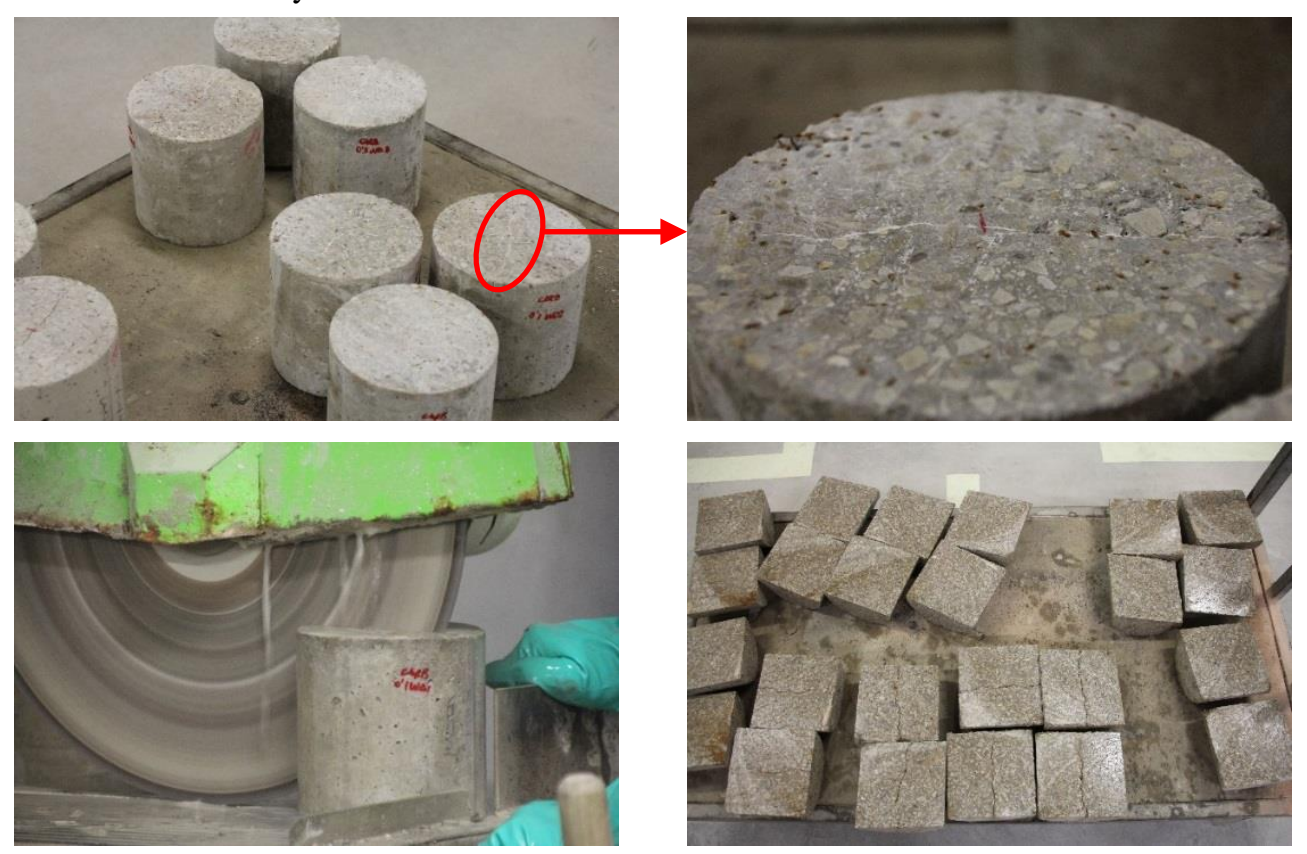

Fig. 5-28. Cutting procedure for concrete specimens 

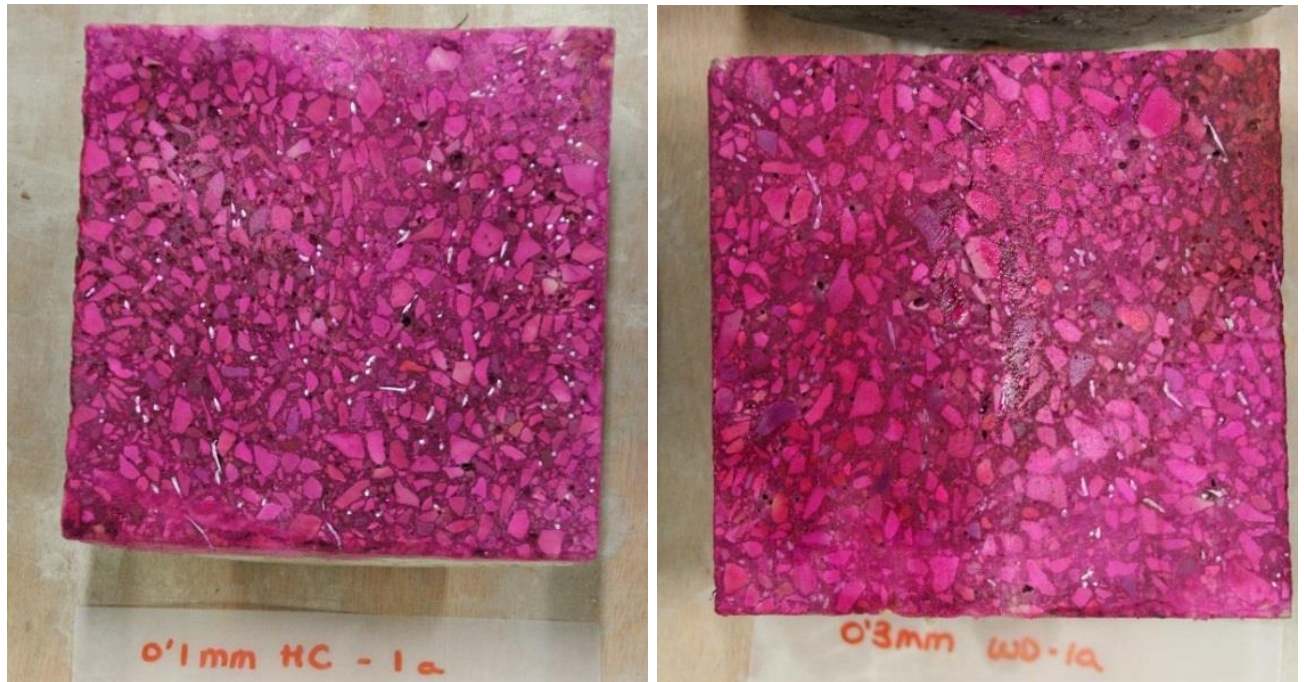

Fig. 5-29. Specimens after the application of the phenolphthalein indicator

However, this cutting process with the saw may remove precipitates formed in the section. Then, the disks cut for the evaluation of internal permeability in section 4.6.1 "Internal healing" with perfect crack sealing after 6 months of healing. These disks were broken into two pieces manually, avoiding the removal of precipitates. The section was also analyzed with phenolphthalein (see Fig. 5-30).

The test showed that only the zone close to the crack presents carbonation (uncolored areas), with a depth between 5 and $10 \mathrm{~mm}$ for most of the disks. Preliminary tests suggest that all specimens of different groups show similar behavior, with much smaller carbonation depth for specimens with smaller cracks (often the whole section turned out magenta) and larger carbonation depths for larger cracks. The test did not show noticeable differences between the control and groups with crystalline admixtures.

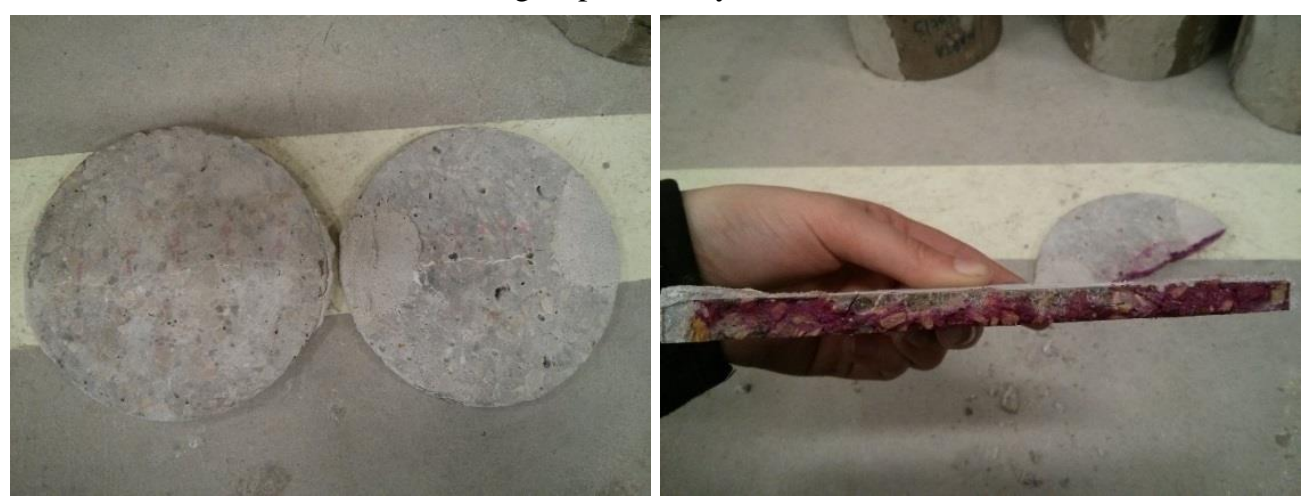

Fig. 5-30. Sealed disks (left) and broken half of a disk after the phenolphthalein test (right). 
These results indicate that the carbonation strictly is not the phenomenon influencing the internal healing of the crack, but is clearly affecting the surface depositions that seal the crack. This is more noticeable for 6-months old specimens after healing, but in specimens healing for 42 days with the cracks visually healed (and whose precipitates are carbonate types) the test was not able to discern the carbonation process. These results support those obtained by Parks et al. (2010) who did not detect carbonation of internal concrete surfaces when cracks were sealed via autogenous healing.

\subsection{Discussion and conclusions about the effectiveness of autogenous healing and crystalline admixtures}

This work has comprehensively analyzed the healing effectiveness of CA in terms of water permeability at high pressure ( 2 bars) and visual closing, for concrete specimens and early age cracks (2-3 days). CA was added in substitution of the fine material (limestone) to isolate the effect of the admixture from the fine effect.

The results showed that CA were not able to heal cracks when stored in $95-100 \%$ of relative humidity. However, when the specimens are healed underwater, CA yield a more stable behavior than autogenous healing. However, the results were not drastically different from the control group and, in general, there was no improvement of visual closing.

When comparing the results for water immersed specimens with those exposed to wet/dry cycles, the latter exposure achieved much higher Closing Ratios than Healing Ratios. This behavior is clear for both groups, CA and control, meaning that the visual sealing of the crack is less related to the permeability healing for specimens under these exposures than for those specimens exposed to water immersion.

Some studies from the literature reported better autogenous healing results for different wet/dry cycles (Ying-zi et al., 2005; Yang et al., 2011; Ma et al., 2014) compared with water immersion, while others achieved better behavior for water immersed specimens (Ter Heide, 2005; Granger et al., 2005; Qian et al., 2009). The results from this research coincide with the latter, and concludes that the more water is available, the more healing would be produced. And this same behavior was replicated for specimens with the crystalline admixtures, showing that the nature of the reaction will be similar to the one produced in autogenous healing, at least in terms of the potential environmental exposures in which concrete elements would be exposed.

With reference to the healing efficiency of concrete with crystalline admixtures healing under water immersion, similar responses were registered by other authors for permeability properties (Sisomphon et al., 2012), with globally less healing capacity, which could be produced by the older precracking age used by those authors. The response under different environmental conditions was not reported before, and shows coherence with the results obtained for autogenous healing in the literature.

Most of the authors cited in the literature review obtained that small cracks heal more easily than larger cracks, Edvardsen (1996; 1999), Reinhardt and Joss (2003), Qian, et al. (2009), Fagerlund and Hassanzadeh (2010), Kim, et al. (2014), Snoeck et al. (2015), among others. Some publications obtained a minimum threshold crack width that must be reached, 
because the water that is necessary for the reactions would enter more easily through cracks of a certain magnitude (Zhong \& Yao, 2008; Li et al., 2011), or better efficiencies for cracks sizes around 0.15-0.20 than 0.10-0.15 (Van Tittelboom et al., 2012). The results from this study also seem to have worse self-healing results for $0.10 \mathrm{~mm}$ than $0.20 \mathrm{~mm}$ cracks, however, in chapter 4 this was demonstrated as an effect of the precision and use of the healing ratios. Without considering the results of the smallest range of cracks, the healing efficiency decreases when the extent of the damage increases. This effect is observed clearly with the Crack Closing Ratio.

Sisomphon, et al. (2013), reported regarding the recovery of mechanical properties of strain-hardening cementitious composites containing of $\mathrm{CA}(1.5 \%$ by weight of cementitious materials), the admixtures little benefit when compared with control specimens. Sisomphon, et al. compared four healing conditions: water immersion in tap water, water immersion in tap water with replacements every 12 hours, wet/dry cycles combining water immersion and drying, 12 hours each cycle and indoor air and wet/dry cycles was the exposure that achieved the highest recoveries of flexural stiffness and flexural strength, while specimens at indoor air achieved the lowest. Their results when adding CA showed good efficiency when added in combination with an expansive agent.

Ferrara et al. (2014) also studied the effect of CA on strength recovery in normal strength concrete specimens, containing CA at a dosage of $1 \%$ by the weight of cement, achieving an improvement of $14 \%$ in the self-healing properties of concrete by the addition of CA with specimens healing underwater. They also indicate that this improvement can be significantly better in High Performance Fiber-Reinforced Composites (Ferrara et al., 2016). The results from this thesis in terms of mechanical recoveries are more aligned with those obtained by Sisomphon, et al. (2013), without peak recoveries and without a significant stiffness recovery. Chapter 4 has also highlighted the high sensitivity of the parameters to the slight variations of the mechanical behavior of concrete and its ageing and maturing processes.

These variations also occurred in the literature regarding autogenous healing. Some studies showed regain of stiffness recovery in ultra-high-performance concrete (Granger et al., 2005 ) when healing in water for 3 weeks, or Kim, et al. (2014) for small cracks $(20 \mu \mathrm{m})$ in HPSFRC showing increase in stiffness and load recovery healing in water in comparison to healing in air. But some studies obtained faster self-healing occurred in the healing condition of water/air cycle, and the higher stiffness recovery was achieved combining cycles with different moist contents (Ma et al., 2014).

The results obtained contrast with the results found in the literature in which differences in the mechanical recoveries were detected when comparing specimens stored under water immersion and those in humidity chambers at different relative humidity values. Results from Ter Heide (2005), and Schlangen, et al. (2006) indicate that in a time between one and two months of water immersion the strength recovery was stabilized, but the results found in this work indicate a lack of peak load recovery and very similar stiffness values for specimens healed in water immersion or in humidity chamber precracked and reloaded at the same age. 
Regarding capillary suction, Fagerlund and Hassanzadeh (2010) analyzed three types of water exposure: permanent and complete immersion, cyclic (1 week immersed in water / 1 week in lab air) and one-sided capillary suction, achieving better results for complete immersion which is coherent with the results obtained in this thesis in the sorptivity analysis.

The results of the characterization of $\mathrm{CA}$ indicate that the chemical composition can be different between products labelled under the same category. According to the XRD analysis of the byproducts produced in the cracks when using CA, they almost the same as for autogenous healing, calcite and brucite, indicating that the reaction produces the same type of byproducts or that their effect is hindered by the normal reactions by autogenous healing. In fact, the presence of brucite could be produced by magnesium in the limestone powder, in the cement or in the CA. Magnesium-based compounds have also been proposed in the literature as self-healing agents due to their expansive behavior (Qureshi \& AlTabbaa, 2016; Sherir et al., 2017).

Regarding the effects that this type of admixture produces into concrete, it is clear that they increase the workability and the strength significantly, as reported in (Weng \& Cheng, 2014) for the case of the strength. In mortar mixes they also increased significantly the setting time and then, the time needed for demolding, but this was not noted in concrete, being able to demold after 24 hours as usual.

The proximity of crystalline admixtures to the industry is a positive point to their inclusion as a new type of admixture for concrete. Nowadays, different products could potentially be used under the label name of crystalline admixtures, since their properties are not clearly defined in standards. These different products may present different behavior depending on their composition and chemical reactions. This fact motivates deeper analyses of what should be labelled under the name of crystalline admixtures and their expected properties. 


\section{Chapter 6. Conclusions}


Self-healing concrete: efficiency evaluation and enhancement with crystalline admixtures 


\subsection{Conclusions}

This thesis aimed to achieve two main goals: 1) to study and develop experimental procedures in order to efficiently evaluate self-healing phenomena and, 2) to evaluate experimentally the self-healing enhancements produced when introducing crystalline admixtures in the cementitious matrix.

The work presented proposes and validates a water permeability method easy to implement in concrete laboratories, but also makes contributions regarding other methodologies, especially in the measure of crack closing. Moreover, it gives further insights to the selfhealing enhancement that can be expected from crystalline admixtures. Several experimental campaigns have been performed to support these results.

This chapter summarizes the contributions of this thesis and presents a list of conclusions that can be drawn from the results herein. These conclusions have been arranged in two subsections "6.1.1 Conclusions on the methodologies to characterize self-healing" and "6.1.2 Conclusions on the self-healing efficiency using crystalline admixtures", which correspond mainly with Chapter 4 and Chapter 5, respectively. Section 6.2 explores possible future lines of research that could be initiated from the results of this thesis. Finally, Section 6.3 ends the Chapter with a list of publications derived by the research presented in this thesis.

\subsubsection{Conclusions on the methodologies to characterize self-healing}

Chapter 4 presented several experimental campaigns with the objective of validating the methodologies proposed to evaluate self-healing. The most extensive work has been carried out in the development and validation of water permeability and crack closing methods for the evaluation of self-healing in concrete. The focus on these two parameters was chosen due to their relevance in the watertightness and durability of structures. The following conclusions can be drawn from the obtained results:

\section{Regarding the precracking processes:}

- Precracking methods with better control are the key point for achieving reliable and comparable results of self-healing between different methods and campaigns.

- This work has used steel fibers to control the creation of cracks of certain widths and to maintain crack width during the healing process. This method allows to produce reliably cracks in the range of $0.10-0.40 \mathrm{~mm}$. Less crack branching was detected when reducing the amount of fibers from 60 to $40 \mathrm{~kg} / \mathrm{m}^{3}$, while maintaining an excellent control of the crack width comparing with the steel wire used in other campaigns.

\section{Regarding water permeability test:}

- The water permeability method proposed in this work uses high-pressured water (2 bars) and allows to discern between uncracked specimens and cracked specimens with width levels between $0.10-0.40 \mathrm{~mm}$.

- One of the most important advantages of this method is that it is easy to implement in concrete laboratories, only requiring a standard permeabilimeter for concrete.

- The method proposed has good stability and repeatability. Slight decreases of the water flow under repeated measurements were detected, which were thought to be produced 
by the entrance of dust or contaminants or by the hydration processes of the cement matrix in the crack. Besides these slight decreases, different levels of crack width were still clearly distinct.

- The use of multiple water permeability tests in a given specimen should be avoided in the experimental campaigns where the expected values will have small range of results, since it might reduce the measures of water flow obtained progressively.

- The water permeability test proposed showed less dispersion than the sorptivity measures, leading to more reliable results.

\section{Regarding crack closing tests:}

- Crack closing is an effective and simple parameter to evaluate self-healing. Four geometrical parameters were analyzed in this work and compared with water permeability results: $w_{\max }$, maximum crack width, $w_{\text {avg }}$, average crack width, $A_{\text {est }}$, estimated crack area and, $A_{p x}$, area measuring black pixels. The experimental work carried out has demonstrated that crack closing is an effective and simple parameter to evaluate self-healing, and the measure of the average crack width by using several equidistant points in the length of the crack $\left(w_{\text {avg }}\right)$, is a cost-effective method to evaluate the damage extent.

- The orientation of the crack during the healing process is of great importance, and not considering this aspect may lead to misleading conclusions.

\section{Relation between crack closing and water permeability tests:}

- Using water permeability as a reference, the crack closing parameters that showed the best adjustment were the area of the crack and the average crack width, as measured in five points along the crack length. Since the use of the average crack width is easier in terms of time of measuring and post-processing of the images, this is the recommended method for crack closing evaluation.

- The relations obtained between crack parameters and water permeability confirmed the cubic relation, as reported in the literature, with some dispersion that was assumed to be produced by the in-depth geometry of the cracks and the presence of fibers. This dispersion was higher for the relation of the parameters after the healing process, which emphasizes the random nature of the healing process.

- The use of crack closing measures as a self-healing parameter could overestimate selfhealing, as reported in the results obtained in Chapter 5.

\section{Regarding the evaluation of mechanical recoveries:}

- Several methodologies and evaluation criteria have been proposed in the literature, which complicates achieving definitive conclusions. This study makes specific studies to introduce concepts that could affect this evaluation.

- The results obtained show that the maturing of concrete is a parameter of noticeable importance and therefore should be considered. This consideration is completely necessary for the evaluation of early age cracks, but it is also recommended in older cracks, since it has been found to affect peak load, stiffness and residual strength. This is of great importance in the experimental campaigns were the expected values will have small range of results, or different reinforcement quantities (for example different 
fiber contents), but could be disregarded for self-healing products with great selfhealing capacity, such as fixed tubes embedding repair materials.

- Regarding the use of different equations, direct expressions had more stable results and were easier to interpret in this study. Therefore, they are the recommended option. The use of appropriated references has also been discussed, depending on the objective of the study.

- The results obtained for strength recovery in this work did not align with the results reported in the literature, which detected stable recoveries after one or two months. The results found in this work indicate a lack of peak load recovery and very similar stiffness values for specimens healed in water immersion or in humidity chamber precracked and reloaded at the same age.

Regarding the use of sorptivity measures:

- Sorptivity analysis tests are easy to implement and allows the use of accompanying specimens without drying the healed specimens in the oven, and evaluating densification and healing processes around the crack. However, the results obtained in this work showed high dispersion and sensitivity to the variations of the cracks introduced during the precracking process

\section{Recommendations for the evaluation of autogenous healing and self-healing with $\mathrm{CA}$ :}

- The healing exposure is of critical importance for the healing processes. Continuous water immersion and wet/dry cycles regimes can achieve achieve almost complete crack closing results in 1-2 months of healing time, results consistent with those presented in the literature review. Humidity chamber showed no healing by means of crack closing nor water permeability, and thus, it was classified as a reference exposure.

- The experimental results obtained show that precracking ages of 2 days and healing times of 28 or 42 days allow to see effects in the crack closing and water permeability of cracks up to $0.35-0.40 \mathrm{~mm}$. Early-age cracks with initial water flows up to around $3000 \mathrm{ml} / 5 \mathrm{~min}$ or crack widths of around $0.20 \mathrm{~mm}$ are likely to have complete healing in terms of both, crack closure and water permeability. In fact, most of the reaction in happened in the first 14 days of healing for early age cracks. Older cracks showed significant but reduced healing capabilities.

- Both autogenous self-healing and autonomous self-healing based on crystal-lineadmixtures have been shown to have a larger effect on the surface of the material. There are some effects in the inside part of the crack as well, but without visual presence of precipitates.

\subsubsection{Conclusions on the self-healing efficiency using crystalline admixtures}

Chapter 5 presented several experimental campaigns with the objective of comparing the efficiency of autogenous healing with that of healing based on the use of crystalline admixtures. The following conclusions can be drawn with respect to the influence of several parameters on self-healing:

- This work is the first instance, to the knowledge of the author, that CA-based selfhealing has been compared under different environmental conditions. The obtained 
results agree with some of the results reported in the literature for autogenous selfhealing. However, some studies from the literature reported better autogenous healing results for different wet/dry cycles compared with water immersion, while others achieved better behavior for water immersed specimens. The results from this research coincide with the latter, both for autogenous healing and when using crystalline admixture. This suggests that the nature of the reaction will be similar to the one produced in autogenous healing, at least in terms of the effect of the potential environmental exposures.

- As in the case of autogenous healing, CA were not able to heal cracks when stored in $95-100 \%$ of relative humidity, and complete immersion led to the best results out of all the experimental methodologies used in this thesis. When the specimens were healed underwater, CA yielded a more stable behavior than autogenous healing. However, the results were not drastically different from the control group, and there was no improvement of visual closing. These results are consistent with those reported by other authors for permeability properties.

- Some studies from the literature have reported a 7-10\% or even higher increase in selfhealing of mechanical properties when using CA with respect to control concrete. This work found no peak recovery and questionable stiffness recoveries. The results concerning the mechanical regain have been shown to be highly sensitive to the evaluation criteria, as well as the mechanical behavior of concrete and its ageing and maturing processes.

- The results of the characterization of the different CA used indicate that their chemical composition can be different, including different proportions of oxides as magnesium, silicon, or sodium. According to the XRD analysis, the byproducts when using CA, were almost the same as for autogenous healing: mainly, calcium carbonate, and magnesium carbonate. This suggests that the reaction of CA produces the same type of byproducts or that their effect is hindered by the normal reactions of autogenous healing.

Crystalline admixtures have been reported as an enhancer of self-healing reactions, but have shown only a limited capacity of enhancement. The proximity of CA to the industry is a positive point to their inclusion as a new type of admixture for concrete. However, the different products used under the name of CA may present different behaviors depending on their composition and formed products. This fact motivates deeper analyses of what should be labelled under this category and their expected properties. 


\subsection{Future lines}

There are several challenging research lines that can be proposed after the work developed in this thesis, such as:

- Development of precracking methods of improved control to create cracks of certain width. These improved methods should also include a technique to maintain crack width unaltered during the healing process. This would allow to achieve more reliable and comparable results between different methods and products.

- Comparative study of self-healing in terms of transport properties, including water permeability (using both, low- and high-pressure), gas permeability, water sorption, and chloride migration. Correlations between these properties after healing.

- Study of the in-depth crack topography and the internal self-healing by using imaging techniques, such as micro-CT scans, to investigate the relation between surface and indepth healings for healing achieved by different products.

- Investigation on the bond and strength of the healing precipitates to the concrete matrix produced under different situations, analyzing their adherence, strength and hardness with microindentation.

- Further insights in the differences between the autogenous healing capacity that is expectable for traditional and ultra-high performance concrete types in terms of transport and mechanical properties.

- Chemical analyses for autogenous healing and crystalline-based healing, in order to differentiate the mineralogical composition of the healing by-products and their evolution with the time under different conditions. 


\subsection{Publications derived from this thesis}

This section includes the list of publications from work derived from this thesis up to 2017.

\section{Refereed JCR journals:}

- N. De Belie, E. Gruyaert, A. Al-Tabbaa, P. Antonaci, C. Baera, D. Bajãre, A. Darquennes, R. Davies, L. Ferrara, A. Jefferson, C. Litina, B. Miljevic, A. Otlewska, J. Ranogajec, M. Roig, K. Paine, P. Ludowski, P. Serna, J.M. Tulliani, S. Vucetic, J. Wang and H. Jonkers. A review on self-healing concrete for damage management of structures. [submitted for publication].

- L. Ferrara, T. Van Mullem, MC Alonso, P. Antonaci, R. Borg, E. Cuenca, A. Jefferson, A. Peled, P-L. Ng, M. Roig-Flores, M. Sanchez, P. Serna, D. Snoeck, C. Schroefl, J-M. Tulliani, N. De Belie (2018). "Experimental characterization of the self-healing capacity of cement based materials and its effects on the material performance: a state of the art report by COST Action SARCOS WG2" Construction and Building Materials, 167, 115-142.

- L. Ferrara, V. Krelani, F. Moretti, M. Roig Flores, P. Serna Ros (2017). "Effects of autogenous healing on the recovery of mechanical performance of High Performance Fibre Reinforced Cementitious Composites (HPFRCCs): Part 1" Cement and Concrete Composites, 83, 76-100.

- M. Roig-Flores, F. Pirritano, P. Serna, L. Ferrara (2016). "Effect of crystalline admixtures on the self-healing capability of early-age concrete studied by means of permeability and crack closing tests" Construction and Building Materials, 114, 447-457.

- M. Roig-Flores, S. Moscato, P. Serna, L. Ferrara (2015). "Self-healing capability of concrete with crystalline admixtures in different environments" Construction and Building Materials, 86, 1-11.

\section{International conferences:}

- M. Roig-Flores, C. Litina, A. Al-Tabbaa, P. Serna. "Capacidad de autosanación de mortero con aditivos cristalinos mediante absorción capilar", V Congreso Iberoamericano de Hormigón Autocompactante y Hormigones Especiales, March 2018, Valencia, Spain [accepted]

- M. Roig-Flores, C. Litina, A. Al-Tabbaa, P. Serna. "Self-healing evaluation of mortar with crystalline admixtures by sorptivity analysis", 6th International Conference on Self-Healing Materials (ICSHM2017), June 2017, Friedrichshafen, Germany.

- M. Roig-Flores, L. Rubio-Garde, P. Serna. "Evaluation methods for the mechanical recovery caused by autogenous healing in concrete", HealCON Conference, November 2016, Delft, The Netherlands.

- L. Ferrara, A. Caggiano, G. di Luzio, G. Etse, R. Gettu, V. Krelani, S. Rocha Ferreira, M. Roig Flores, P. Serna and R. Diaz Toledo Filho "Five years of international collaborative research on self-healing capacity of cementitious composites", fib Symposium, November 2016, Cape Town, South Africa. 
- L. Ferrara, I. Albertini, R. Gettu, V. Krelani, S. Moscato, F. Pirritano, M. Roig Flores, P. Serna Ros and S.M. Theeda "Self healing of cement based materials engineered through crystalline admixtures: experimental results from a multinational university network" ACI Symposium on Durability and Sustainability of Concrete Structures Workshop Proceedings, October 2015, Bologna, Italy.

- L. Ferrara, M. Geminiani, R. Gorlezza, V. Krelani, M. Roig Flores, G. Sanchez Arevalo and P. Serna Ros. "Autogeneous self healing of High Performance Fibre Reinforced Cementitious Composites", HPFRCC-7, Proceedings of the 7th RILEM workshop on High Performance Fiber Reinforced Cement Composites, June 2015, Stuttgart, Germany. RILEM Pubs., ISBN 9782351581452.

- M. Roig-Flores, F. Pirritano, P. Serna, L. Ferrara. "Study of the self-healing behavior of early-age cracks in concrete with crystalline admixtures under six environmental exposures", V International Conference on Self-Healing Materials (ICSHM2015), June 2015, Durham, North Carolina, United States.

- M. Roig-Flores, S. Moscato, P. Serna-Ros, L. Ferrara. "Self-healing capability of concrete containing crystalline admixtures in different exposure conditions", fib Symposium 2015, May 2015, Copenhagen, Denmark.

- L. Ferrara, V. Krelani, M. Geminiani, R. Gorlezza, P. Serna Ros, M. Roig Flores, G. Sanchez Arevalo "Capacita' di autoriparazione dei compositi cementizi fibrorinforzati ad elevate prestazioni"

\section{Other relevant documents:}

Contributions to the State of the Art reports developed in the framework of the COST Action Sarcos "Self-healing As preventive Repair of COncrete Structures". In particular, the contributions were done in the sections concerning self-healing concrete with crystalline admixtures and crack closing methods for the evaluation of self-healing. 



\section{References}

ACI Committee 212, 2010. Report on chemical admixtures for concrete. American Concrete Institute (ACI), Chapter 15(Report ACI 212-3R-10), pp.46-50.

Ahn, T.-H. \& Kishi, T., 2010. Crack Self-healing Behavior of Cementitious Composites Incorporating Various Mineral Admixtures. Journal of Advanced Concrete Technology, 8 (2), pp.171-86.

Aldea, C.M., Shah, S.P. \& Karr, A., 1999. Permeability of cracked concrete. Materials and Structures/Matériaux et Constructions, 32, pp.370-76.

Alghamri, R., Kanellopoulos, A. \& Al-Tabbaa, A., 2016. Impregnation and encapsulation of lightweight aggregates for self-healing concrete. Construction and Building Materials, 124, pp.910-21.

Alyousif, A., Lachemi, M., Yildirim, G. \& Şahmaran, M., 2015. Effect of self-healing on the different transport properties of cementitious composites. Journal of Advanced Concrete Technology, 13(3), pp.112-23.

Castanier, S., Le Métayer-Levrel, G. \& Perthuisot, J.-P., 1999. Ca-carbonates precipitation and limestone genesis - the microbiogeologist point of view. Sedimentary Geology, 126, pp.9-23.

Cement Sustainability Initiative, 2009. Recycling Concrete. Washington: World Business Council for Sustainable Development.

CNN, 2016. The 'living concrete' that can heal itself. CNN, 7 March.

Çopuroğlu, O., Schlangen, E., Nishiwaki, T., Tittelboom, K.V., Snoeck, D., Belie, N.D. \& Rooij, M.R.d., 2013. Experimental Techniques Used to Verify Healing. In Self-Healing Phenomena in Cement-Based Materials. State-of-the-Art Report of RILEM Technical Committee 221-SHC. Springer.

Darquennes, A., Olivier, K., Benboudjema, F. \& Gagné, R., 2016. Self-healing at early-age, a way to improve the chloride resistance of blast-furnace slag cementitious materials. Construction and Building Materials, 113, pp.1017-28.

De Belie, N., 2016. Application of bacteria in concrete: a critical review. RILEM Technical Letters, 1, pp.56-61.

De Nardi, C., Bullo, S., Cecchi, A. \& Ferrara, L., 2016. Self-healing capacity of advanced lime mortars. Advances in Materials and Processing Technologies, 2(3), pp.349-60.

De Rooij, M.R., Schlangen, E. \& Joseph, C., 2013. Introduction. In M. De Rooij, K. Van Tittelboom, N. De Belie \& E. Schlangen, eds. Self-healing Phenomena in Cement-based Materials: State-of-the-art Report of RILEM Technical Committee 221-SHC. Springer RILEM State-of-the-Art Reports. pp.1-17.

Desmettre, C., 2011. Contribution à l'étude de la perméabilité du béton armé sous sollicitations statiques et cycliques. École Polytechnique de Montréal. 
Desmettre, C. \& Charron, J.-P., 2012. Water permeability of fiber reinforced concrete subjected to constant and cyclic loading. In BEFIB2012 - Fibre reinforced concrete. UM, Guimarães, 2012. Joaquim Barros et al. (Eds).

Dong, H., Huang, H. \& Ye, G., 2013. Inorganic powder encapsulated in brittle polymer particles for self-healing cement-based materials. International Conference on Self-Healing Materials (ICSHM2013).

Dry, C., 1994. Matrix cracking repair and filling using active and passive modes for smart timed release of chemicals from fibers into cement matrices. Smart Mater. Struct., 3, pp.118-23.

Dry, C.M., 2000. Three designs for the internal release of sealants, adhesives, and waterproofing chemicals into concrete to reduce permeability. Cement and Concrete Research, 30, pp.1969-77.

Dry, C. \& McMillan, W., 1996. Three-part methylmethacrylate adhesive system as an internal delivery system for smart responsive concrete. Smart Mater. Struct., 5, pp.297-300.

Edvardsen, C.K., 1996. Wasserdurchlässigkeit und Selbstheilung von Trennrissen in Beton. Berlin: Beuth.

Edvardsen, C., 1999. Water Permeability and Autogenous Healing of Cracks in Concrete. ACI Materials Journal, 96(4), pp.448-54.

Fagerlund, G. \& Hassanzadeh, M., 2010. Self-healing of cracks in concrete long-term exposed to different types of water: results after 1 year exposure. Report TVBM.

Feiteira, J., Gruyaert, E. \& De Belie, N., 2016. Self-healing of moving cracks in concrete by means of encapsulated polymer precursors. Construction and Building Materials, 102, pp.671-78.

Fernández Cánovas, M., 1994. Patología y terapéutica del hormigón armado. ETS de Ingenieros de Caminos, Canales y Puertos de Madrid.

Fernández Cánovas, M., Selva, N.H. \& Kawiche, G.M., 1992. New economical solutions for improvement of durability of Portland cement mortars reinforced with sisal fibres. Materials and Structures, 25, pp.417-22.

Ferrara, L., Krelani, V. \& Carsana, M., 2014. A “fracture testing” based approach to assess crack healing of concrete with and without crystalline admixtures. Construction and Building Materials, 68, pp.535-51.

Ferrara, L., Krelani, V. \& Moretti, F., 2016. On the use of crystalline admixtures in cement based construction materials: from porosity reducers to promoters of self healing. Smart Materials and Structures, 25, p.084002.

Freyssinet, E., 1951. The deformation of concrete. Magazine of Concrete Research, 3(8), pp.49-56.

Friedrich, S., 2012. Superabsorbent Polymers (SAP). In V. Mechtcherine \& H.-W. Reinhardt, eds. Application of Super Absorbent Polymers (SAP) in Concrete Construction: State-of-the-Art Report Prepared by Technical Committee 225-SAP. Springer RILEM State-of-the-Art Reports. pp.13-19. 
Fukuda, D., Nara, Y., Hayashi, D., Ogawa, H. \& Kaneko, K., 2013. Influence of Fracture Width on Sealability in High-Strength and Ultra-Low-Permeability Concrete in Seawater. Materials 2013, (6), pp.2578-94.

Gagné, R. \& Argouges, M., 2012. A study of the natural self-healing of mortars using airflow measurements. Materials and Structures.

García-Calvo, J.L., Pérez, G., Carballosa, P., Erkizia, E., Gaitero, J.J. \& Guerrero, A., 2017. Development of ultra-high performance concretes with self-healing micro/nano-additions. Construction and Building Materials, (138), pp.306-15.

Ghosh, S., Biswas, M., Chattopadhyay, B.D. \& Mandal, S., 2009. Microbial activity on the microstructure of bacteria modified mortar. Cement \& Concrete Composites, 31, pp.93-98.

Giannaros, P., Kanellopoulos, A. \& Al-Tabbaa, A., 2016. Sealing of cracks in cement using microencapsulated sodium silicate. Smart Materials and Structures, 25, pp.1-12.

Granger, S., Loukili, A., Pijaudier-Cabot, G. \& Chanvillard, G., 2005. Mechanical characterization of the self-healing effect of cracks in Ultra High Performance Concrete (UHPC). In Proceedings Third International Conference on Construction Materials, Performance, Innovations and Structural Implications, ConMat, 5, pp.22-24.

Granger, S., Loukili, A., Pijaudier-Cabot, G. \& Chanvillard, G., 2007. Experimental characterization of the self-healing of cracks in an ultra high performance cementitious material: Mechanical tests and acoustic emission analysis. Cement and Concrete Research, (37), pp.519-27.

Gray, R.J., 1984. Autogenous Healing Of Fibre/Matrix Interfacial Bond In FibreReinforced Mortar. Cement and Concrete Research, 14, pp.315-17.

Hannant, D.J. \& Keer, J.G., 1983. Autogenous Healing of Thin Cement-based Sheets. Cement and Concrete Research, 13, pp.357-65.

Hearn, N., 1998. Self-sealing, autogenous healing and continued hydration: What is the difference? Materials and Structures/Matériaux et Constructions, 31, pp.563-67.

Hearn, N. \& Morley, C., 1997. Self-sealing property of concrete - Experimental evidence. Materials and Structures/Matériaux et Constructions, 30, pp.404-11.

Herbert, E.N. \& Li, V.C., 2013. Self-Healing of Microcracks in Engineered Cementitious Composites (ECC) Under a Natural Environment. Materials, (6), pp.2831-45.

Homma, D., Mihashi, H. \& Nishiwaki, T., 2009. Self-Healing Capability of Fibre Reinforced Cementitious Composites. Journal of Advanced Concrete Technology, 7(2), pp.217-28.

Hosoda, A., Komatsu, S., Ahn, T., Kishi, T., Ikeno, S. \& Kobayashi, K., 2009. Self healing properties with various crack widths under continuous water leakage. In Concrete Repair, Rehabilitation and Retrofitting II. London: Taylor \& Francis Group. pp.221-27.

Huang, H., 2014. Thermodynamics of Autogenous Self-healing in Cementitious Materials. [PhD] Delft, The Netherlands: Technische Universiteit Delft. 
Huang, H. \& Ye, G., 2011. Application of sodium silicate solution as self-healing agent in cementitious materials. International RILEM conference on advances in construction materials through science and engineering, pp.530-36.

Huang, H. \& Ye, G., 2015. Self-healing of cracks in cement paste affected by additional $\mathrm{Ca} 2+$ ions in the healing agent. Journal of Intelligent Material Systems and Structures, 26(3), pp.309-20.

Huang, H., Ye, G. \& Damidot, D., 2013. Characterization and quantification of self-healing behaviors of microcracks due to further hydration in cement paste. Cement and Concrete Research, (52), pp.71-81.

Huang, H., Ye, G. \& Damidot, D., 2014. Effect of blast furnace slag on self-healing of microcracks in cementitious materials. Cement and Concrete Research, 60, pp.68-82.

Ikoma, H., Kishi, T., Sakai, Y. \& Kayondo, M., 2015. Elucidation of Rapid Reduction of Water Flow through Concrete Crack Regarded as Self-healing Phenomenon. Fifth International Conference on Self-Healing Materials, Durham.

Imperial College London, 2012. Self-sealing cracks with superabsorbent polymer. [Online] Available

http://www3.imperial.ac.uk/concretedurability/researchprojects/selfsealingconcrete

[Accessed 23 February 2015].

Jacobsen, S., Granl, H.C., Sellevold, E.J. \& Bakke, J.A., 1995. High Strength Concrete Freeze/Thaw Testing and Cracking. Cement ad Concrete Research, 25(8), pp.1775-80.

Jacobsen, S., Marchand, J. \& Boisvert, L., 1996. Effect of cracking and healing on chloride transport in OPC concrete. Cement and Concrete Research, 26(6), pp.869-81.

Jacobsen, S., Marchand, J. \& Homain, H., 1995. SEM observations of the microstructure of frost deteriorated and self-healed concretes. Cement and Concrete Research, 25(8), pp.1781-90.

Jacobsen, S. \& Sellevold, E.J., 1996. Self Healing of High Strength Concrete after Deterioration by Freeze/Thaw. Cement and Concrete Research, 26(1), pp.55-62.

Jaroenratanapirom, D. \& Sahamitmongkol, R., 2011. Self-Crack Closing Ability of Mortar with Different Additives. Journal of Metals, Materials and Minerals, 21(1), pp.9-17.

Jefferson, A., Joseph, C., Lark, R., Isaacs, B., Dunn, S. \& Weager, B., 2010. A new system for crack closure of cementitious materials using shrinkable polymers. Cement and Concrete Research, (40), pp.795-801.

Jiang, Z., Li, W. \& Yuan, Z., 2015. Influence of mineral additives and environmental conditions on the self-healing capabilities of cementitious materials. Cement and Concrete Composites, 57, pp.116-27.

Jonkers, H.M., 2011. Bacteria-based Self-healing Concrete. HERON, 56(1/2).

Jonkers, H.M. \& Schlangen, E., 2007. Crack repair by Concrete-Immobilized Bacteria. Proceedings of the First International Conference on Self Healing Materials.

Jonkers, H.M. \& Schlangen, E., 2008. Development of a bacteria-based self healing concrete. Tailor Made Concrete Structures, pp.425-30. 
Jonkers, H.M., Thijssen, A., Muyzer, G., Copuroglu, O. \& Schlangen, E., 2010. Application of bacteria as self-healing agent for the development of sustainable concrete. Ecological Engineering, 36, pp.230-35.

Jonkers, H., Thijssen, A., Muyzer, G., Copuroglu, O. \& Schlangen, E., 2010. Application of bacteria as self-healing agent for the development of sustainable concrete. Ecological engineering, 36(2), pp.230-35.

Joos, M., 2001. Leaching of Concrete under thermal influence. Otto-Graf-Journal, 12, pp.51-68.

Joseph, C., Jefferson, A.D., Isaacs, B., Lark, R. \& Gardner, R., 2010. Experimental investigation of adhesive-based self-healing of cementitious materials. Magazine of Concrete Research, 62(11), pp.831-43.

Kanellopoulos, A., Giannaros, P. \& Al-Tabbaa, A., 2016. The effect of varying volume fraction of microcapsules on fresh, mechanical and self-healing properties of mortars. Construction and Building Materials, 122, pp.577-93.

Kanellopoulos, A., Giannaros, P., Palmer, D., Kerr, A. \& Al-Tabbaa, A., 2017. Polymeric microcapsules with switchable mechanical properties for self-healing concrete: synthesis, characterisation and proof of concept. Smart Materials and Structures, 26(4), p.045025.

Kanellopoulos, A., Qureshi, T.S. \& Al-Tabbaa, A., 2015. Glass encapsulated minerals for self-healing in cement based composites. Construction and Building Materials, 98, pp.78091.

Karaiskos, G., Tsangouri, E., Aggelis, D.G., Deraemaeker, A. \& Van Hemelrijck, D., 2015. Damage detection monitoring applications in self-healing concrete structures using embedded piezoelectric transducers and recovery. In 11th International Conference on Damage Assessment of Structures., 2015. Journal of Physics: Conference Series 628.

Karaiskos, G., Tsangouri, E., Aggelis, D.G., Van Tittelboom, K., De Belie, N. \& Van Hemelrijck, D., 2016. Performance monitoring of large-scale autonomously healed concrete beams under four-point bending through multiple non-destructive testing methods. Smart Materials and Structures, 25, p.055003.

Kim, D.J., Kang, S.H. \& Ahn, T.-H., 2014. Mechanical Characterization of HighPerformance Steel-Fiber Reinforced Cement Composites with Self-Healing Effect. Materials, 7, pp.508-26.

Kim, J.S. \& Schlangen, E., 2011. Self-Healing in ECC stimulated by SAP under flexural cyclic load. Proceedings of 3rd International Conference on Self Healing Materials, Bath, $U K$, pp.27-29.

Lawler, J.S., Wilhelm, T., Zampini, D. \& Shah, S.P., 2003. Fracture processes of hybrid fiber-reinforced mortar. Materials and Structures / Matériaux et Constructions, 36, pp.197208.

Lee, H.X.D., Wong, H.S. \& Buenfeld, N.R., 2016. Self-sealing of cracks in concrete using superabsorbent polymers. ement and Concrete Research, 79, pp.194-208.

Li, V.C., Limb, Y.M. \& Chanc, Y.-W., 1998. Feasibility study of a passive smart selfhealing cementitious composite. Composites, 29B, pp.819-27. 
Li, V.C. \& Yang, E.-H., 2007. Self Healing in Concrete Materials. In S.v.d. Zwaag, ed. Self Healing Materials. An Alternative Approach to 20 Centuries of Materials Science. Springer. pp.161-93.

Li, Z., Zhou, Z., Xu, D. \& Yu, J., 2011. Influence of Cement Coarse Particle on the SelfHealing Ability of Concrete Based on Ultrasonic Method. Advanced Materials Research, 177, pp.526-29.

Ma, H., Qian, S. \& Zhang, Z., 2014. Effect of self-healing on water permeability and mechanical property of Medium-Early-Strength Engineered Cementitious Composites. Construction and Building Materials, (68), pp.92-101.

Martys, N.S. \& Ferraris, C.F., 1997. Capillary transport in mortars and concrete. Cement and Concrete Research, 27(5), pp.747-60.

Mignon, A., Snoeck, D., Schaubroeck, D., Luickx, N., Dubruel, P., Van Vlierberghe, S. \& De Belie, N., 2015. pH-responsive superabsorbent polymers: A pathway to self-healing. Reactive and Functional Polymers, (93), pp.68-76.

Mihashi, H. \& Nishiwaki, T., 2012. Development of engineered self-healing and selfrepairing concrete-state-of-the-art report. Journal of Advanced Concrete Technology, 10(5), pp.170-84.

Morandeau, A., Thiérya, M. \& Dangla, P., 2014. Investigation of the carbonation mechanism of $\mathrm{CH}$ and C-S-H in terms of kinetics, microstructure changes and moisture properties. Cement and Concrete Research, 56, pp.153-70.

Na, S.H., Hama, Y., Taniguchi, M., Katsura, O., Sagawa, T. \& Zakaria, M., 2012. Experimental Investigation on Reaction Rate and Self-healing Ability in Fly Ash Blended Cement Mixtures. Journal of Advanced Concrete Technology, 10(7), pp.240-53.

Neate, E.C. \& Bowling, W.F., 1944. Reinforced-Concrete Transmission Line Supports. Journal of the Institution of Electrical Engineers - Part II: Power Engineering, 91(22), pp.355-58.

Neville, A.M., 2011. Properties of Concrete. 5th ed. Pearson.

Nishiwaki, T., Koda, M., Yamada, M., Mihashi, H. \& Kikuta, T., 2012. Experimental Study on Self-Healing Capability of FRCC Using Different Types of Synthetic Fibers. Journal of Advanced Concrete Technology, 10, pp.195-206.

Nishiwaki, T., Kwon, S., Homma, D., Yamada, M. \& Mihashi, H., 2014. Self-Healing Capability of Fiber-Reinforced Cementitious Composites for Recovery of Watertightness and Mechanical Properties. Materials, (7), pp.2141-54.

Olivier, K., Darquennes, A., Benboudjema, F. \& Gagné, R., 2013. Etude de l'autocicatrisation des matériaux cimentaires avec additions minérales après fissuration au jeune âge par retrait gene. 3lèmes Rencontres de l'AUGC, E.N.S. Cachan.

Palin, D., Wiktor, V. \& Jonkers, H., 2015. Autogenous healing of marine exposed concrete: Characterization and quantification through visual crack closure. Cement and Concrete Research, 73, pp.17-24. 
Palin, D., Wiktor, V. \& Jonkers, H., 2016. A bacteria-based bead for possible self-healing marine concrete applications. Smart Materials and Structures, 25, p.084008 (6pp).

Pang, S.D., Tran Diep, P.T. \& Quek, S.T., 2011. Self-Healing Concrete Structural Elements. 3rd International Conference on Self-Healing Materials.

Papadakis, V., Vayenas, C. \& Fardis, M., 1989. A reaction engineering approach to the problem of concrete carbonation. AIChE Journal, 35(10), pp.1639-50.

Parks, J., Edwards, M., Vikesland, P. \& Dudi, A., 2010. Effects of Bulk Water Chemistry on Autogenous Healing of Concrete. Journal of Materials in Civil Engineering, 22(5), pp.515-24.

Pelletier, M.M., Brown, R., Shukla, A. \& Bose, A., 2011. Self-healing concrete with a microencapsulated healing agent. Cement and Concrete Research.

Perez, G., Gaitero, J.J., Erkizia, E., Jimenez, I. \& Guerrero, A., 2015. Characterisation of cement pastes with innovative self-healing system based in epoxy-amine adhesive. Cement \& Concrete Composites, 60, pp.55-64.

Pérez, G., García Calvo, J.L., Carballosa, P., Tian, R., Allegro, V.R., Erkizia, E., Gaitero, J.J. \& Guerrero, A., 2017. Durability of self-healing ultra-high-strength reinforced microconcrete under freeze-thaw or chloride attack. Magazine of Concrete Research, 69(23), pp.1231-42.

Pérez, G., Jiménez, I., Erkizia, E., Gaitero, J.J., Kaltzakorta, I. \& Guerrero, A., 2013. Effect of self-healing additions on the development of mechanical strength of cement paste. Chemistry and Materials Research, 5, pp.102-05.

Powers, T., Copeland, L., Hayes, J. \& Mann, H., 1954. Permeability of Portland cement paste. J. Am. Concr. Inst., 51 , pp.285-98.

Qian, S., Zhou, J., de Rooij, M.R., Schlangen, E., Ye, G. \& van Breugel, K., 2009. Selfhealing behavior of strain hardening cementitious composites incorporating local waste materials. Cement \& Concrete Composites, (31), pp.613-21.

Qian, S.Z., Zhou, J. \& Schlangen, E., 2010. Influence of curing condition and precracking time on the self-healing behavior of Engineered Cementitious Composites. Cement \& Concrete Composites, (32), pp.686-93.

Qureshi, T.S. \& Al-Tabbaa, A., 2016. Self-healing of drying shrinkage cracks in cementbased materials incorporating reactive MgO. Smart Materials and Structures, 25(8), p.084004.

Qureshi, T.S., Kanellopoulos, A. \& Al-Tabbaa, A., 2016. Encapsulation of expansive powder minerals within a concentric glass capsule system for self-healing concrete. Construction and Building Materials, 121 , pp.629-43.

Ranachowski, Z., Józwiak-Niedzwiedzka, D., Ranachowski, P., Rejmund, F., Dabrowski, M., Kudela, S. \& Dvorak, T., 2014. Application of X-Ray Microtomography and Optical Microscopy to Determine the Microstructure. Archives Of Metallurgy And Materials, 59(4).

Reinhardt, H.-W. \& Joss, M., 2003. Permeability and self-healing of cracked concrete as a function of temperature and crack width. Cement and Concrete Research, (33), pp.981-85. 
Roig-Flores, M., Moscato, S., Serna, P. \& Ferrara, L., 2015. Self-healing capability of concrete with crystalline admixtures in different environments. Construction and Building Materials, 86, pp.1-11.

Roig-Flores, M., Pirritano, F., Serna, P. \& Ferrara, L., 2016. Effect of crystalline admixtures on the self-healing capability of early-age concrete studied by means of permeability and crack closing tests. Construction and Building Materials, 114, pp.447-57.

Sahmaran, M., Yildirim, G. \& Erdem, T.K., 2013. Self-healing capability of cementitious composites incorporating different supplementary cementitious materials. Cement \& Concrete Composites, (35), pp.89-101.

Schlangen, E., Jonkers, H., Qian, S. \& Garcia, A., 2010. Recent advances on self healing of concrete. Jeju, Korea, 2010. Proceedings FRAMCOS7.

Schlangen, E., ter Heide, N. \& van Breugel, K., 2006. Crack Healing of early age cracks in concrete. In M.S. Konsta-Gdoutos, ed. Measuring, Monitoring and Modeling Concrete Properties. Springer. pp.273-84.

Schlegel, H.G., 2003. General Microbiology. Séptima ed. Translated by M. Kogut. Cambridge University Press.

Schröfl, C., Mechtcherine, V. \& Gorges, M., 2012. Relation between the molecular structure and the efficiency of superabsorbent polymers (SAP) as concrete admixture to mitigate autogenous shrinkage. Cement and Concrete Research, (42), pp.865-73.

Scrivener, K.L., 1984. Development of Microstructure during the Hydration of Portland. $\mathrm{Ph}$. D Thesis University of London.

Shahid, K.A., Jaafar, M.F.M. \& Yahaya, F.M., 2014. Self-healing behaviour of pre-cracked POFA-concretes in different curing conditions. Journal of Mechanical Engineering and Sciences, 7, pp.1127-235.

Sherir, M.A.A., Hossain, K.M.A. \& Lachemi, M., 2017. The influence of MgO-type expansive agent incorporated in self-healing system of Engineered cementitious Composites. Construction and Building Materials, 149, pp.164-85.

Siddique, R. \& Chahal, N.K., 2011. Effect of ureolytic bacteria on concrete properties. Construction and Building Materials, 25, pp.3791-801.

Sierra-Beltrán, M. \& Jonkers, H., 2015. Field application of self-healing concrete with natural fibres as linings for irrigation canals in Ecuador. Fifth International Conference on Self-Healing Materials, Durham (USA).

Silva, E.F., Moreira, M., Manzano, M.R. \& Blanco, R., 2017. Case study of permeabilityreducing admixture use in anti-flotation slabs: building in Brasilia, Brazil. Journal of Building Pathology and Rehabilitation, 2(1), p.1.

Sisomphon, K. \& Copuroglu, O., 2011. Self healing mortars by using different cementitious materials. International RILEM Conference on Advances in Construction Materials through Science and Engineering. Eds. Christopher Leung, and KT WAN. RILEM Publications SARL: Hong Kong, China. 
Sisomphon, K., Copuroglu, O. \& Fraaij, A., 2011. Application of encapsulated lightweight aggregate impregnated with sodium monofluorophosphate as a self-healing agent in blast furnace slag mortar. HERON, 56(1/2).

Sisomphon, K., Copuroglu, O. \& Koenders, E.A.B., 2012. Self-healing of surface cracks in mortars with expansive additive and crystalline additive. Cement \& Concrete Composites, 34, pp.566-74.

Sisomphon, K., Copuroglu, O. \& Koenders, E.A.B., 2013. Effect of exposure conditions on self healing behavior of strain hardening cementitious composites incorporating various cementitious materials. Construction and Building Materials, 42, pp.217-24.

Snoeck, D., André Smetryns, P. \& De Belie, N., 2015. Improved multiple cracking and autogenous healing in cementitious materials by means of chemically-treated natural fibres. Biosystems Engineering, 139, pp.87-99.

Snoeck, D. \& De Belie, N., 2012. Mechanical and self-healing properties of cementitious composites reinforced with flax and cottonised flax, and compared with polyvinyl alcohol fibres. biosystems engineering, 111(4), pp.325-35.

Snoeck, D. \& De Belie, N., 2015. Repeated Autogenous Healing in Strain-Hardening Cementitious Composites by Using Superabsorbent Polymers. Journal of Materials in Civil Engineering (ASCE), 28(1).

Snoeck, D., Dewanckele, J., Cnudde, V. \& De Belie, N., 2016. X-ray computed microtomography to study autogenous healing of cementitious materials promoted by superabsorbent polymers. Cement and Concrete Composites, 65, pp.83-93.

Snoeck, D., Dubruel, P. \& De Belie, N., 2013. Microfibres and hydrogels to promote autogenous healing in cementitious materials. 4th International conference on Self-Healing Materials (ICSHM 2013)., pp.17-20.

Snoeck, D., Smetryns, P. \& De Belie, N., 2015. Improved multiple cracking and autogenous healing in cementitious materials by means of chemically-treated natural fibres. Biosystems Engineering, 139, pp.87-99.

Snoeck, D., Van Tittelboom, K., Steuperaert, S., Dubruel, P. \& De Belie, N., 2014. Selfhealing cementitious materials by the combination of microfibres and superabsorbent polymers. Journal of Intelligent Material Systems and Structures, 25(1), pp.13-24.

Speck, O., Schlechtendahl, M., Schmich, F. \& Speck, T., 2013. Self-healing processes in plants - A treasure trove for biomimetic self-repairing materials. Ghent, 2013. Fourth International Conference on Self-Healing Materials.

Sun, L., YU, W.-Y. \& Ge, Q., 2011. Experimental research on the self - healing performance of micro - cracks in concrete bridge. Advanced Materials Research, 250-253, pp.28-32.

Teall, O., Davies, R., Pilegis, M., Kanellopoulos, A., Sharma, T., Paine, K., Jefferson, A., Lark, R., Gardner, D. \& Al-Tabbaa, A., 2016. Self-healing concrete full scale site trials. Proceedings of the 11th fib International PhD Symposium in Civil Engineering, pp.639-46.

Ter Heide, N., 2005. Crack healing in hydrating concrete. Delft, The Netherlands: Delft University of Technology, Faculty of Civil Engineering and Geosciences. Tesis de Master. 
Termkhajornkit, P., Nawa, T., Yamashiro, Y. \& Saito, T., 2009. Self-healing ability of fly ash-cement systems. Cement \& Concrete Composites, (31), pp.195-203.

Toledo Filho, R.D., Ghavami, K., Sanjuán, M.A. \& England, G.L., 2005. Free, restrained and drying shrinkage of cement mortar composites reinforced with vegetable fibres. Cement \& Concrete Composites, (27), pp.537-46.

Van Breugel, K., 2007. Is there a market for self-healing cement-based materials? Proceedings of the First International Conference on Self Healing Materials, Noordwijk aan Zee, The Netherlands.

Van der Zwaag, S., 2007. An Introduction to Material Design Principles: Damage Prevention versus Damage Management. In S.V.d. Zwaag, ed. Self Healing Materials. An Alternative Approach to 20 Centuries of Materials Science. Dordrecht, The Netherlands: Springer. pp.1-18.

Van Tittelboom, K., Adesanya, K., Dubruel, P., Puyvelde, P.V. \& de Belie, N., 2011. Methyl methacrylate as a healing agent for self-healing cementitious materials. Smart Mater. Struct., 20.

Van Tittelboom, K., De Belie, N., Lehmann, F. \& Grosse, C.U., 2012. Acoustic emission analysis for the quantification of autonomous crack healing in concrete. Construction and Building Materials, 28, pp.333-41.

Van Tittelboom, K., De Belie, N., Muynck, W.D. \& Verstraete, W., 2010. Use of bacteria to repair cracks in concrete. Cement and Concrete Research, (40), pp.157-66.

Van Tittelboom, K., De Belie, N., Van Loo, D. \& Jacobs, P., 2011. Self-healing efficiency of cementitious materials containing tubular capsules filled with healing agent. Cement \& Concrete Composites, (33), pp.497-505.

Van Tittelboom, K., Gruyaert, E., Rahier, H. \& de Belie, N., 2012. Influence of mix composition on the extent of autogenous crack healing by continued hydration or calcium carbonate formation. Construction and Building Materials, (37), pp.349-59.

Van Tittelboom, K., Snoeck, D., Vontobel, P., Wittmann, F.H. \& De Belie, N., 2013. Use of neutron radiography and tomography to visualize the autonomous crack sealing efficiency in cementitious materials. Materials and Structures, 46(1), pp.105-21.

Van Tittelboom, K., Tsangouri, E., Van Hemelrijck, D. \& De Belie, N., 2015. The efficiency of self-healing concrete using alternative manufacturing procedures and more realistic crack patterns. Cement \& Concrete Composites, 57, pp.142-52.

Wagner, E.F., 1974. Autogenous Healing of Cracks in Cement-Mortar Linings for GrayIron and Ductile-Iron Water Pipe. American Water Works Association, 66(6), pp.358-60.

Wang, J.Y., de Belie, N. \& Verstraete, W., 2012. Diatomaceous earth as a protective vehicle for bacteria applied for self-healing concrete. J Ind Microbiol Biotechnol, 39, pp.567-77.

Wang, J.Y., Soens, H., Verstraete, W. \& De Belie, N., 2014. Self-healing concrete by use of microencapsulated bacterial spores. Cement and Concrete Research, 56, pp.139-52. 
Wang, J., Mignon, A., Snoeck, D., Wiktor, V., Boon, N. \& De Belie, N., 2015. Application of modified-alginate encapsulated carbonate producing bacteria in concrete: a promising strategy for crack self-healing. Front Microbiol, 6, p.1088.

Wang, J., van Tittelboom, K., de Belie, N. \& Verstraete, W., 2012. Use of silica gel or polyurethane immobilized bacteria for self-healing concrete. Construction and Building Materials, 26, pp.532-40.

Weng, T.L. \& Cheng, A., 2014. Influence of curing environment on concrete with crystalline admixture. Monatshefte für Chemie-Chemical Monthly, 145(1), pp.195-200.

Whiffin, V.S., 2004. Microbial CaCO3 precipitation for the production of Biocement. Murdoch University, Australia: Doctoral dissertation, Murdoch University. PhD Thesis.

White, S.R., Sottos, N.R., Geubelle, P.H., Moore, J.S., Kessler, M.R., Sriram, S.R., Brown, E.N. \& Viswanathan, S., 2001. Autonomic healing of polymer composites. NATURE, 409.

Wiktor, V. \& Jonkers, H.M., 2011. Quantification of crack-healing in novel bacteria-based self-healing concrete. Cement \& Concrete Composites, 33, pp.763-70.

Yang, Z., Hollar, J., He, X. \& Shi, X., 2011. A self-healing cementitious composite using oil core/silica gel shell microcapsules. Cement \& Concrete Composites, 33, pp.506-12.

Yang, Y., Lepech, M.D., Yang, E.-H. \& Li, V.C., 2009. Autogenous healing of engineered cementitious composites under wet-dry cycles. Cement and Concrete Research, 39, pp.382-90.

Yang, Y.-Z., Lepech, M.D., Yang, E.-H. \& Li, V.C., 2009. Autogenous healing of engineered cementitious composites under wet-dry cycles. Cement and Concrete Research, 39, pp.382-90.

Yang, Y., Yang, E.-H. \& Li, V.C., 2011. Autogenous healing of engineered cementitious composites at early age. Cement and Concrete Research, 41, pp.176-83.

Yildirim, G., Aras, G.H., Banyhussan, Q.S., Şahmaran, M. \& Lachemi, M., 2015. Estimating the self-healing capability of cementitious composites through non-destructive electrical-based monitoring. NDT\&E International, 76, pp.26-37.

Yildirim, G., Sahmaran, M. \& Ahmed, H.U., 2014. Influence of Hydrated Lime Addition on the Self-Healing Capability of High-Volume Fly Ash Incorporated Cementitious Composites. Journal of Materials in Civil Engineering.

Ying-zi, Y., Lepech, M.D. \& Li, V.C., 2005. Self-healing of Engineered Cementitious Composites under cycling wetting and drying. Proceedings International Workshop on Durability of Reinforced Concrete under Combined Mechanical and Climatic Loads (CMCL), Qingdao, China, pp.231-42.

Yingzi, Y., Yang, E.-H. \& Li, V.C., 2011. Autogenous healing of engineered cementitious composites at early age. Cement and Concrete Research, (41), pp.176-83.

Zhang, M., Han, N., Xing, F., Wang, X. \& Schlangen, E., 2013. Evaluation of a Microcapsule based self-healing system for cementitious materials. International Conference on Self-Healing Materials (ICSHM2013). 
Zhang, Z., Qian, S. \& Ma, H., 2014. Investigating mechanical properties and self-healing behavior of micro-cracked ECC with different volume of fly ash. Construction and Building Materials, (52), pp.17-23.

Zhong, W. \& Yao, W., 2008. Influence of damage degree on self-healing of concrete. Construction and Building Materials, (22), pp.1137-42.

Zhou, Z., Li, Z., Xu, D. \& Yu, J., 2011. Influence of Slag and Fly Ash on the Self-healing Ability of Concrete. Advanced Materials Research, 306-307, pp.1020-23. 
References 